\title{
Review of $\mathrm{Bi}_{2} \mathrm{O}_{3}$-based glasses for electronics and related applications
}

\author{
Thomas Maeder \\ Laboratoire de Production Microtechnique (LPM) \\ École Polytechnique Fédérale de Lausanne (EPFL) \\ BM 1.136, Station 17, CH-1015 Lausanne, Switzerland \\ thomas.maeder@epfl.ch
}

13.2.2013

\begin{abstract}
The present work critically reviews the scientific and patent literature on low-melting bismuth-based oxide glass frits in materials for electronics, sensors and related applications such as sealing glasses, solar cells, architectural and automotive glass, the main motivation being to replace lead-based materials by environmentally more benign ones. Due to similar glass-forming properties of $\mathrm{Bi}$ and $\mathrm{Pb}$, Bi-based glasses are the closest "drop-in" alternative for lead-bearing formulations, and are therefore actually replacing them in many applications, helped also by previous experience with Bi-containing materials in thick-film technology and component metallisations. The outstanding issues are discussed, e.g. matching the lowest processing temperatures achieved by the classical lead-based glasses without sacrificing durability and stability, as well as stability vs. chemical reduction. Finally, consideration is also given to special "heavy" glasses (often containing $\mathrm{Bi}$ and $\mathrm{Pb}$ together) that are useful in fields such as optics, superconductors and nuclear technology, as well as to specific $\mathrm{Bi}_{2} \mathrm{O}_{3^{-}}$ containing crystalline compounds.
\end{abstract}

Keywords: Glasses; Bismuth; $\mathrm{Bi}_{2} \mathrm{O}_{3}$; Electronics; Optics; Thick-film technology; Sensors

Note. Parts of this work are based on a previous conference paper ${ }^{1}$. 
Th. Maeder - IMR 2012 - Review of $\mathrm{Bi}_{2} \mathrm{O}_{3}$-based glasses (9.10.2012) - 2

\section{Table of contents}

1. INTRODUCTION...

1.1. LOW-MELTING GLASSES IN ELECTRONICS AND OTHER APPLICATIONS …………............................................... 3

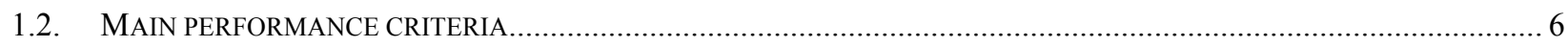

1.3. PBO IN LOW-MELTING FRITS \& THICK-FILM TECHNOLOGY ............................................................................. 7

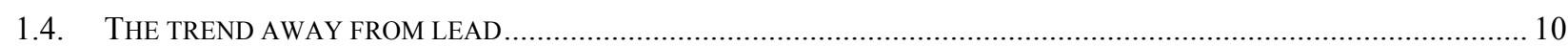

2. LOW-MELTING FRITS - ALTERNATIVE SYSTEMS ……....................................................................... 11

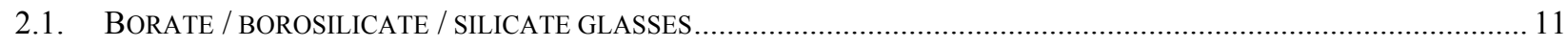

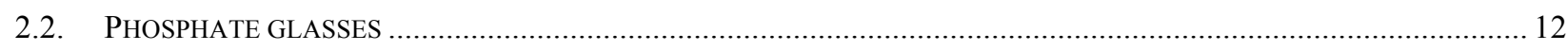

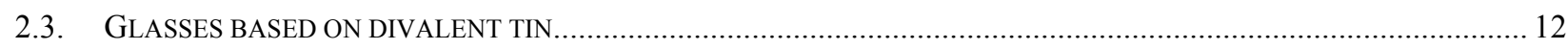

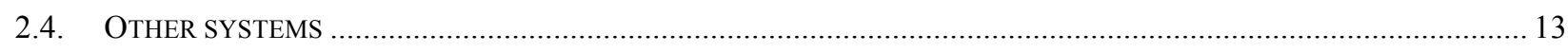

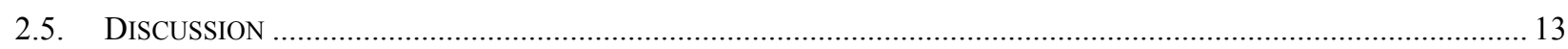

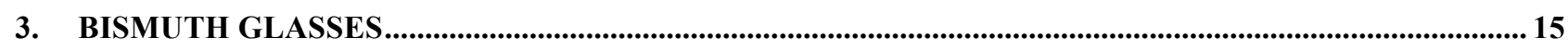

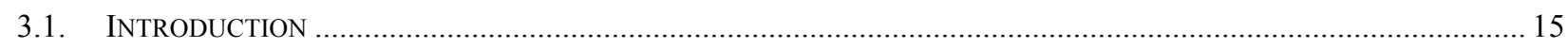

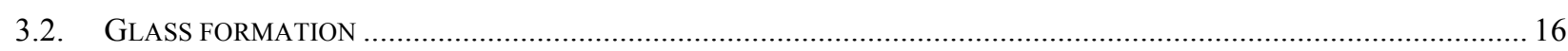

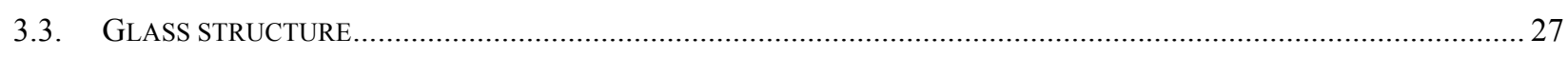

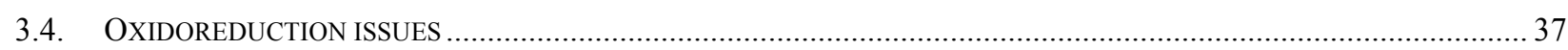

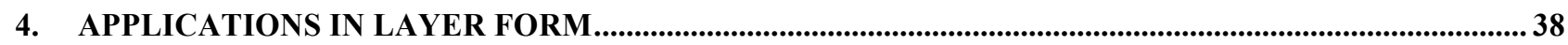

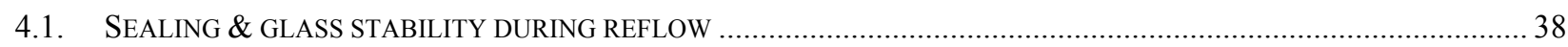

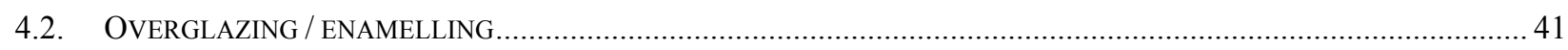

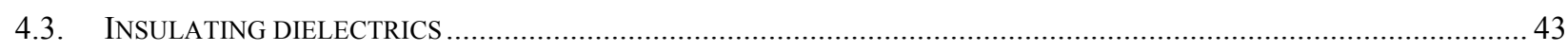

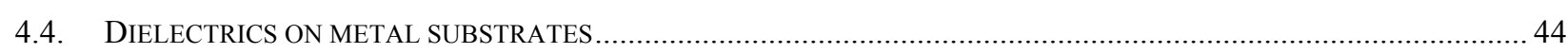

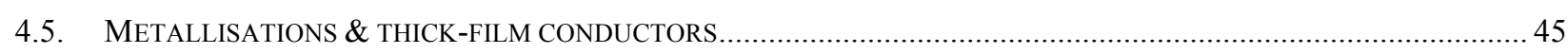

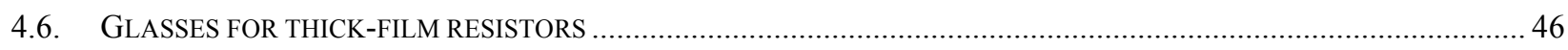

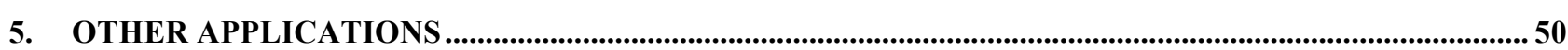

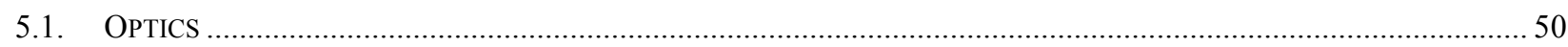

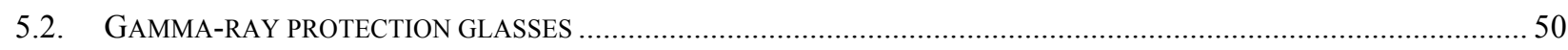

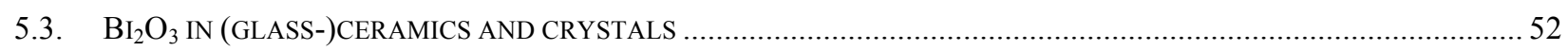

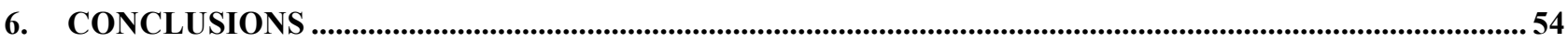

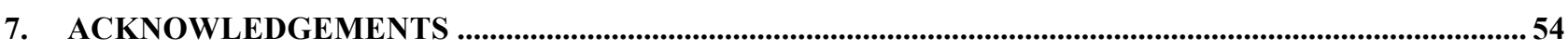

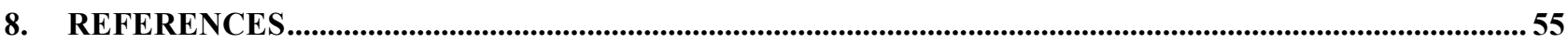

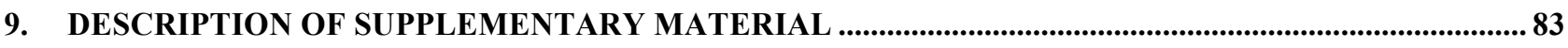

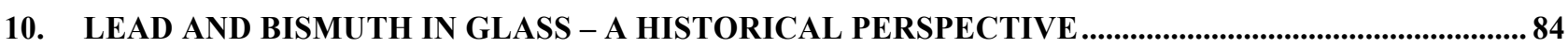

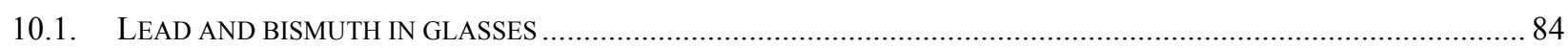

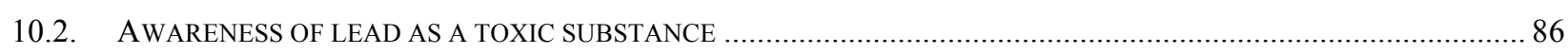

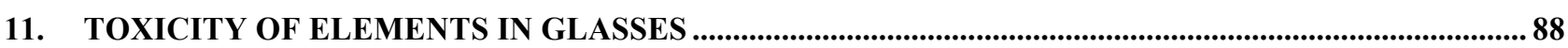

12. OXIDATION STATE OF BI SPECIES IN GLASSES .........................................................................91

13. COORDINATION OF BISMUTH IN CRYSTALLINE OXIDES ................................................................94

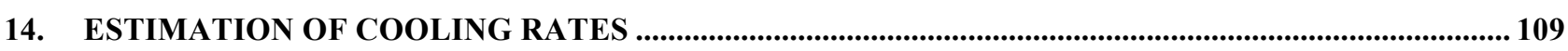

15. ADDITIONAL REFERENCES FOR SUPPLEMENTS.......................................................................... 111 


\section{Introduction}

\subsection{Low-melting glasses in electronics and other applications}

As for ceramics, inorganic glasses, glass-ceramic and glaze materials have long gone beyond their traditional uses to address a wide array of modern technological challenges, ${ }^{2-43}$ in fields such as electrical engineering / electronics / sensors, ${ }^{9-32}$ solar energy, ${ }^{42,}{ }^{43}$ protective and decorative coatings, ${ }^{20,}{ }^{27-35}$ optics / optical telecommunications, ${ }^{36,37}$ structural mechanics, ${ }^{8}$ medical, ${ }^{38}$ nuclear technology, ${ }^{6,7}$ superconductors ${ }^{39}$ and microfluidics. ${ }^{40,41}$

Due to performance and cost criteria, most standard glasses have relatively high softening points. However, there are many technological applications where a low softening temperature is required, in order to lower energy expenditure, avoid damaging devices in contact with the glass during processing or ensure compatibility with other materials:

- Hermetic sealing of packages, lamps, electrical feedthroughs and semiconductor devices ${ }^{13,14,16,17,19,44,45}$

- Hermetic sealing and mechanical attachment of sensors ${ }^{23,27}$ (Figure 1)

- Encapsulation of semiconductor devices ${ }^{29,30}$

- Overglazing of automotive, packaging and architectural glass $33,34,46-48$

- Photovoltaic (PV) solar cell technology - conductors \& contacts $^{42,43,49-53}$

- Enamelling of aluminium in architecture and home appliances ${ }^{35,54-58}$

- Thick-film (TF) electronics and other devices ${ }^{21,22,24,25,27,59}$ on various substrates: $:^{60}$ glasses for resistor (TFR), ${ }^{61,62}$ conductor, ${ }^{63,64}$ overglaze, dielectric ${ }^{65}$ and sealing ${ }^{15-19}$ materials (Figure 1, section 1.3); especially, special low-firing compositions for fabrication of circuits and sensors on glass or metals $1,28,66-72$

For these applications, glasses are often formulated as frits (i.e. finely divided powder), which may be applied - dispersed in a suitable medium - onto a substrate by various methods such as slip casting, screen printing, roller/ curtain coating, spraying, dispensing and electrophoresis, or as preforms for sealing. Classically, the aforementioned applications have to a great extent used lead-based glasses, which have a rather unique combination of desirable properties, ${ }^{10-12}$ as will be discussed hereafter in section 1.3. Table 1 compiles the compositions and melting points / processing temperatures of selected classical low-melting lead-based glasses.

Figure 1 shows a thick-film integrated pressure sensor ${ }^{27}$ that illustrates many of the aforementioned applications: hermetic sealing of the sensing membrane combined with mechanical attachment and electrical contact, encapsulation through an hermetic dielectric of a wetted surface, conductors, resistors and overglazes. 
Table 1. Representative compositions (cation\%*) of low-melting lead-based glasses. Temperatures $=$ melting points (eutectics) or processing temperatures (others).

\begin{tabular}{|c|c|c|c|c|c|c|c|c|c|}
\hline Applications & $\begin{array}{l}\text { Temp. } \\
{\left[{ }^{\circ} \mathrm{C}\right]}\end{array}$ & $\begin{array}{c}\mathbf{P b} \\
{[\%]}\end{array}$ & $\begin{array}{c}\mathbf{Z n} \\
{[\%]}\end{array}$ & $\begin{array}{c}\mathbf{B i} \\
{[\%]}\end{array}$ & $\begin{array}{c}\mathbf{A l} \\
{[\%]}\end{array}$ & $\begin{array}{c}\mathbf{B} \\
{[\%]}\end{array}$ & $\begin{array}{c}\mathbf{S i} \\
{[\%]}\end{array}$ & Others & Code \\
\hline \multirow{3}{*}{ (Eutectics) $\dagger$} & 493 & 52 & - & - & - & 48 & - & & PDC-0282 \\
\hline & 484 & 49 & - & - & - & 41 & 10 & & PDC-0741 \\
\hline & 739 & 30 & - & - & - & - & 70 & & PDC-5173 \\
\hline \multirow{3}{*}{$\begin{array}{l}\text { Sealing } \\
(\text { stable })^{73}\end{array}$} & $390-410$ & 52 & 8 & - & - & 40 & - & & Sck-11 \\
\hline & $410-430$ & 42 & 7 & - & - & 51 & - & & Sck-16 \\
\hline & $480-500$ & 40 & - & - & 11 & 31 & 18 & & Sck-27 \\
\hline \multirow{4}{*}{$\begin{array}{c}\text { Sealing } \\
\text { (crystallising) } \\
\mathrm{Hiz}^{74} / \mathrm{Bob}^{75}\end{array}$} & \multirow{4}{*}{$420-450$} & 45 & 17 & - & 3 & 31 & 4 & & Hiz-C3 \\
\hline & & 43 & 17 & - & 3 & 32 & 5 & & Hiz-C5 \\
\hline & & 48 & 15 & - & 3 & 30 & 4 & & Hiz-C9 \\
\hline & & 46 & 17 & - & - & 32 & 5 & & Bob-00 \\
\hline \multirow{7}{*}{$\begin{array}{c}\text { "Classical" } \\
\text { TFR frits } \\
\text { Pru }^{62,76-81} \\
\mathrm{H}_{81} 1^{82}\end{array}$} & \multirow{7}{*}{$800-900$} & 19 & - & - & 18 & 49 & 14 & & Pru-F5 \\
\hline & & 31 & - & - & 13 & - & 56 & & Pru-F7 \\
\hline & & 36 & - & - & 2 & - & 62 & & Pru-F8 \\
\hline & & 40 & - & - & - & - & 60 & & H81-01 \\
\hline & & 26 & - & - & 5 & 28 & 41 & & H81-04 \\
\hline & & 33 & - & - & 2 & - & 65 & & H81-05 \\
\hline & & 22 & - & - & 4 & 24 & 33 & $17 \mathrm{Li} 1 \mathrm{Zr}$ & H81-10 \\
\hline \multirow{3}{*}{$\begin{array}{l}\text { Low-firing } \\
\text { TFR frits } \\
67-69,71,83-86\end{array}$} & $700-750$ & 23 & - & - & 3 & 58 & 16 & & L-V2 \\
\hline & $550-625$ & 37 & - & - & 4 & 32 & 27 & & L-V6 \\
\hline & $430-550$ & 48 & - & - & 5 & 36 & 11 & & L-V8 \\
\hline \multirow{2}{*}{$\begin{array}{l}\text { Conductor } \\
\text { frits }\end{array}$} & \multirow{2}{*}{$600-850$} & 9 & - & 7 & - & 18 & 10 & & $\mathrm{C}-1^{87}$ \\
\hline & & 15 & - & 36 & - & 14 & 15 & $20 \mathrm{Ca}$ & $\mathrm{C}-2^{88}$ \\
\hline $\begin{array}{l}\text { "Crystal" } \\
\text { Glass } 89,90\end{array}$ & $\approx 850$ & 11 & - & - & - & 1 & 68 & $\begin{array}{c}1 \mathrm{Na} 19 \mathrm{~K} \\
0.2 \mathrm{As}\end{array}$ & Hyn-LC \\
\hline
\end{tabular}

*Compositions on a cation basis, i.e.. $\mathrm{LiO}_{0.5}, \mathrm{NaO}_{0.5}, \mathrm{PbO}, \mathrm{ZnO}, \mathrm{BiO}_{1.5}, \mathrm{AlO}_{1.5}, \mathrm{BO}_{1.5}, \mathrm{SiO}_{2}$, etc..

$\dagger \mathrm{PDC}=$ Phase diagrams for ceramists (figure nr. given): $1-2066^{91}, 2067-4149^{92}, 4150-4999^{93}, 5000-5590^{94}$. 
While most low-melting glasses are used on a substrate or for sealing, there are several significant "bulk" applications of low-melting or relatively low-melting glasses:

- $\quad$ Lead "crystal" glass ${ }^{89}$

- Glasses for nuclear waste immobilisation ${ }^{6,95-98}$

- $\quad$ Leaded CRT tube glass ${ }^{89}$

- Superconductor synthesis - bulk or film - via the glass-ceramic route $39,99-105$

- Heavy metal oxide (HMO) glasses with high refraction indices and far infrared (IR) transmission for optical devices \& communications ${ }^{36,106-128}$

- HMO glasses for gamma radiation shielding ${ }^{129-135}$

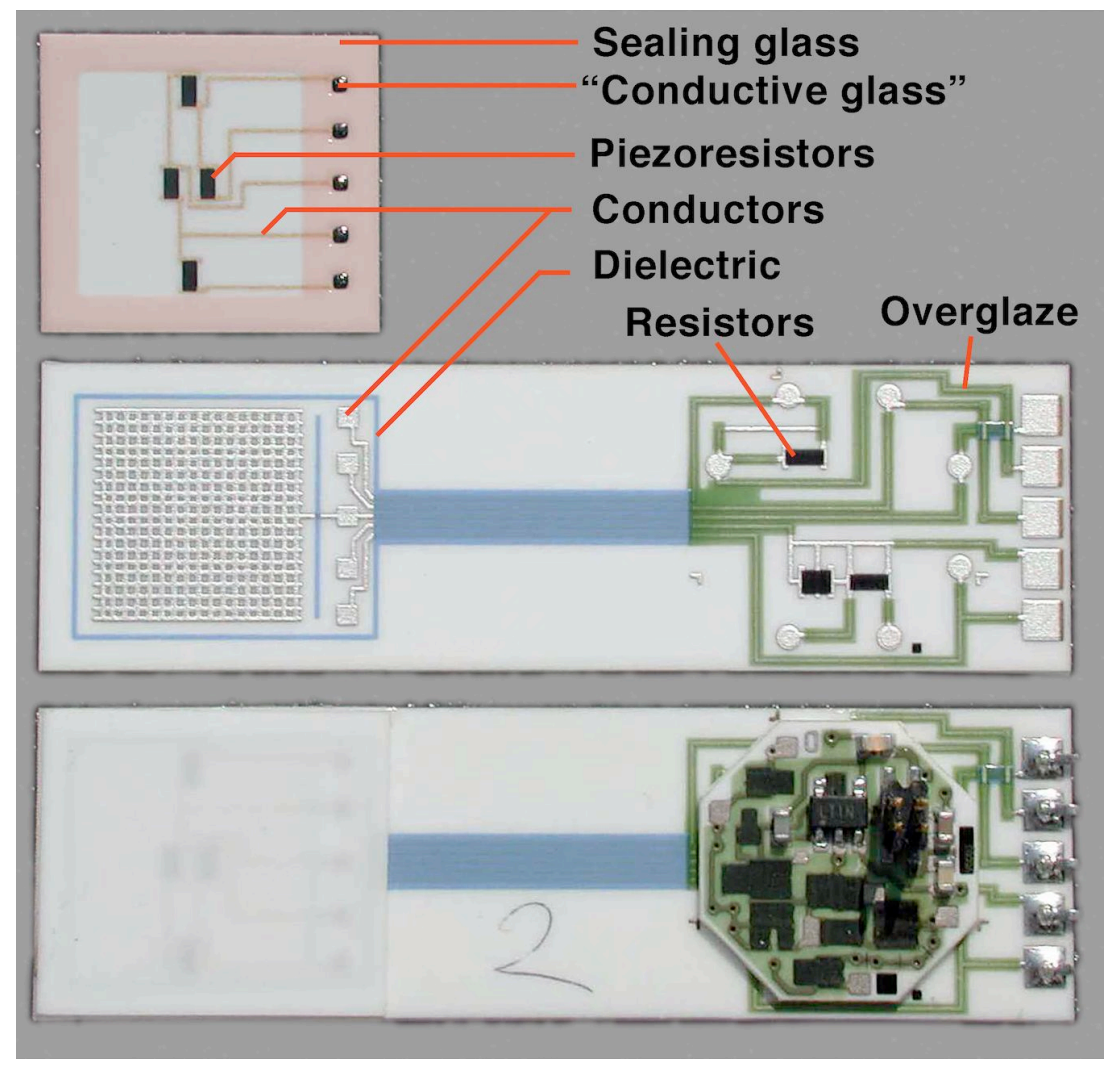

Figure 1. Example thick-film circuit - piezoresistive pressure sensor ${ }^{27}$ - showing typical involved materials. Reddish tint added to sealing glass to enhance visibility; "conductive glass" seal = low-firing TFR composition. 


\subsection{Main performance criteria}

The performance criteria in selecting a low-melting glass depend on the application. A short overview is given in Table 2 (layers \& sealing) and Table 3 (bulk) for the aforementioned applications. In contrast to most "film" applications, most of the "bulk" examples listed above depend specifically on the presence in the glass of HMOs, rather than just require a reliable low-melting glass. In optics, heavy, polarisable cations such as $\mathrm{Pb}^{2+}$ and $\mathrm{Bi}^{3+}$ impart to the glass a high diffraction index, a high dispersion, strong nonlinear effects, and better IR transmission, ${ }^{12,36,112}$, whereas CRT and gamma radiation shielding benefits from the strong absorption of ionising radiation by heavy elements. ${ }^{11,129,130}$

Table 2. Requirements for (relatively) low-melting glasses for layers and seals. "-" = normally not important; "+" = significant; "++" = critical.

\begin{tabular}{|c|c|c|c|c|c|}
\hline $\begin{array}{l}\text { Property } \\
\text { Application }\end{array}$ & $\begin{array}{l}\text { Low process } \\
\text { temperature }\end{array}$ & $\begin{array}{l}\text { High service } \\
\text { temperature }\end{array}$ & $\begin{array}{l}\text { Thermal expansion } \\
\text { matching }\end{array}$ & $\begin{array}{l}\text { Good chemical } \\
\text { durability }\end{array}$ & $\begin{array}{l}\text { Good electrical } \\
\text { insulation }\end{array}$ \\
\hline $\begin{array}{l}\text { Hermetic package } \\
\text { sealing }\end{array}$ & $+/++^{a}$ & + & $+/++^{b}$ & $+{ }^{\mathrm{d}}$ & - \\
\hline $\begin{array}{l}\text { Sensor sealing \& } \\
\text { fastening }\end{array}$ & + & $+/++^{\mathrm{c}}$ & ++ & $+^{\mathrm{d}}$ & $-1+{ }^{\mathrm{e}}$ \\
\hline $\begin{array}{l}\text { Encapsulation of } \\
\text { semiconductors }\end{array}$ & $++{ }^{\mathrm{f}}$ & + & $++^{g}$ & $+^{\mathrm{d}}$ & $++^{\mathrm{h}}$ \\
\hline Enamelling & $-/+^{i}$ & $-1+$ & $++^{b}$ & $+/++^{\mathrm{j}}$ & - \\
\hline $\mathrm{TF}$ - overglazes & $+{ }^{i}$ & $-1+$ & $+{ }^{b}$ & $+/++{ }^{\mathrm{j}, \mathrm{k}}$ & $+/++$ \\
\hline $\mathrm{TF}$ - resistors & $-1+i$ & $+/++$ & $++^{b}$ & $-/+$ & - \\
\hline $\mathrm{TF}$ - conductors & $-1+i$ & - & - & $-1+$ & - \\
\hline TF - dielectrics & $-/+i$ & $+/++$ & ++ & + & $++^{\mathrm{h}}$ \\
\hline
\end{tabular}

(a) Critical for sealing organic parts \& semiconductors / thin-film devices.

(b) Match not critical for thin layers on planar substrates - avoid tensile stresses.

(c) Stress relaxation $\rightarrow$ risk of signal drift.

(d) Depends on environment; protection of seal with organics sometimes possible.

(e) Often significant due to seal overlapping conductor tracks - see Figure 1.

(f) Critical to avoid degradation. ${ }^{45}$

(g) Difficult combination of low process temperature \& low thermal expansion, especially directly on chip, achieved through fillers. ${ }^{18}$

(h) Surface states in semiconductors also important ${ }^{29,30}-$ reduce / avoid alkalis, which are mobile under electric field.

(i) Important on sensitive substrates / other layers, e.g. glass, metals, pre-fired TFRs.

(j) Critical for underwater applications ${ }^{27}$ or for automotive. ${ }^{48}$

(k) Needed for acid plating baths. 


\subsection{PbO in low-melting frits \& thick-film technology}

Thick-film electronics makes wide use of glassy compounds, used as main components of overglazes, permanent binders for dielectrics and resistors, and also as frits / adhesion promoters for conductors. ${ }^{21,22,24,59,61-65}$ Note that the technology and materials are very similar for other applications such as architectural / automotive / solar-cell overglazes and conductors.

For conductors, resistors and overglazes (and relatively old dielectrics), most classical lowmelting frits are based on the $\mathrm{PbO}-\mathrm{B}_{2} \mathrm{O}_{3}$ (lead borate) system, with mainly $\mathrm{SiO}_{2}, \mathrm{ZnO}$ and $\mathrm{Al}_{2} \mathrm{O}_{3}$ additions. Several phase diagrams and property maps exist for these systems. ${ }^{21,91-93,136-}$ 144

Table 1 gives several representative "traditional" glass compositions, compared with that of traditional leaded "crystal" glass ${ }^{89}$ and some representative eutectic compositions in the phase diagrams. Throughout this work, compositions are given on a cation basis unless specified otherwise, as by Dumbaugh and Lapp; ${ }^{36}$ this convention facilitates comparison with $\mathrm{Bi}_{2} \mathrm{O}_{3}-$ based glasses when $\mathrm{PbO}$ is replaced by approximately equimolar amounts of " $\mathrm{BiO}_{1.5}$ ".

By altering the composition, the properties, especially the processing temperature and the tendency to crystallise, can be easily and reliably tuned. Low-melting glasses in this system, which have a composition relatively close to the $\mathrm{PbO}-\mathrm{B}_{2} \mathrm{O}_{3}$ binary eutectic, allow a reduction in binder glass amount in TF conductors, and/or a decrease of processing temperatures down to ca. $400^{\circ} \mathrm{C}$ for low-temperature TF conductors, dielectrics, overglazes and resistors, ${ }^{67,72,85}$, 86 for glass sealing ("solder glasses") of cathode ray tubes (CRTs) and flat panel displays (FPDs), or for glass encapsulation of semiconductor devices. ${ }^{15,16,73,74}$

Low-melting glasses in the lead zinc borosilicate system can be formulated as essentially "stable", i.e. with little or no crystallisation during firing or sealing, or devitrifying, i.e. forming significant amounts of crystalline phase and thus conserving dimensional stability upon later reheating. These latter crystallising glasses are referred to as glass ceramics, vitroceramics, or "cements" in glass-sealing parlance. In these compositions, devitrification is usually favoured by high amounts of $\mathrm{ZnO}$, whereas $\mathrm{B}_{2} \mathrm{O}_{3}, \mathrm{SiO}_{2}$ and $\mathrm{Al}_{2} \mathrm{O}_{3}$ tend to stabilise the glassy state (Table 1). To achieve even lower processing temperatures and/ or promote wetting, compounds such as $\mathrm{CuO}, \mathrm{Fe}_{2} \mathrm{O}_{3}, \mathrm{Bi}_{2} \mathrm{O}_{3}, \mathrm{~V}_{2} \mathrm{O}_{5}, \mathrm{WO}_{3}, \mathrm{MoO}_{3}$ and fluorine (batched as $\mathrm{CaF}_{2}, \mathrm{PbF}_{2}, \mathrm{ZnF}_{2}, \mathrm{BiF}_{3} \ldots$ ) can be added to the glass formulation. ${ }^{19,} 75,145-152$ Interestingly, fluorine, which is effective in lowering the processing temperature, was found to have better compatibility with glasses where a sizeable amount of $\mathrm{PbO}$ was replaced by $\mathrm{Bi}_{2} \mathrm{O}_{3}{ }^{149}$ Very low processing temperatures may be reached by glasses largely based on $\mathrm{PbO}-\mathrm{TeO}_{2},{ }^{45} \mathrm{PbO}-$ $\mathrm{V}_{2} \mathrm{O}_{5}{ }^{145,147,148}$ and especially $\mathrm{SnO}-\mathrm{SnF}_{2}-\mathrm{PbO}-\mathrm{PbF}_{2}-\mathrm{P}_{2} \mathrm{O}_{5}{ }^{153}$

Glass frits are often used in conjunction with other materials that act as fillers (Table 4): insulating powders for dielectrics / overglazes / encapsulation / sealing glasses, ${ }^{18,67,145,147,149-}$ 152, 154 conductive oxides for resistors, ${ }^{1,}, 62,155-157$ metal powders $\&$ adhesion promoters for conductors, ${ }^{63,64,88,158-160}$ pigments, ... Even for applications such as sealing, encapsulation or thick-film overglazes, where they are not intrinsically required, fillers are often found necessary or advantageous in practice, mainly to adjust the coefficient of thermal expansion (CTE) of the deposited material to that of the substrate(s) - see Donald's review ${ }^{20}$ for an extensive list of filler CTEs. The filler can also be used as a nucleating agent to better control the crystallisation process of a devitrifying glass. Alternatively or additionally, chemical and mechanical stabilisation of a glass can be obtained by reaction with the filler; an example is the reaction of lead-bearing glass with $\mathrm{TiO}_{2}$ and $\mathrm{MoO}_{3},{ }^{161,162}$ yielding both an increase of the filler volume (by formation of $\mathrm{PbTiO}_{3} / \mathrm{PbMoO}_{4}$ ) and of the glass softening point (by the resulting depletion of glass $\mathrm{PbO}$ content). 
Correctly formulated, both stable and devitrifying lead-based glasses achieve an excellent combination of very consistent and reliable properties, relatively large processing windows, acceptable corrosion resistance and low processing temperatures, all this without requiring, in their composition, alkaline oxides, which are detrimental for insulating properties (due to the mobility of alkaline ions under electric fields) and chemical durability, and impart a high CTE that is deleterious in most cases (except for substrates with CTE $>\approx 10 \mathrm{ppm} \mathrm{K}^{-1}$ ). Due to these advantages, which have been recognised for a long time (see supplement 10), these leadbased glasses have achieved widespread use, and have been the object of extensive studies and reviews. ${ }^{10-12}$

An overview of the current status of commercial thick-film compositions is given in

Table 5; modern multilayer dielectric compositions such as ESL 4913 are commonly leadfree, ${ }^{163}$ and recently-introduced (relatively) low-melting overglaze materials use $\mathrm{Bi}_{2} \mathrm{O}_{3}$ instead of PbO. Surprisingly, even an old composition such as Ag:Pd conductor DP 9473 uses a $\mathrm{Bi}_{2} \mathrm{O}_{3}$-based glass. ${ }^{164}$

Table 3. Requirements for low-melting "bulk" glasses. "-" = normally not important; "+" = significant; "++" = critical

\begin{tabular}{|c|c|c|c|c|}
\hline Application & $\begin{array}{l}\text { Low process } \\
\text { temperature }\end{array}$ & $\begin{array}{c}\text { Optical } \\
\text { properties }\end{array}$ & $\begin{array}{c}\text { Radiation } \\
\text { shielding }\end{array}$ & $\begin{array}{l}\text { Good chemical } \\
\text { durability }\end{array}$ \\
\hline "Crystal" glass (see Table 1) & $+^{\mathrm{a}}$ & $++^{\mathrm{b}}$ & - & $+/++^{\mathrm{c}}$ \\
\hline CRT tube & $+^{\mathrm{a}}$ & $-{ }^{\mathrm{d}}$ & $++^{\mathrm{d}}$ & $-/+$ \\
\hline Optical devices & $+^{\mathrm{a}}$ & $++^{\mathrm{e}}$ & - & $-/+$ \\
\hline$\gamma$-ray shielding & $+^{\mathrm{a}}$ & $+^{\mathrm{f}}$ & ++ & $-1+$ \\
\hline Waste immobilisation & $+^{\mathrm{a}}$ & - & + & $++^{\mathrm{c}}$ \\
\hline \multicolumn{5}{|c|}{$\begin{array}{l}\text { Notes: (a) minimal volatilisation of toxic / radioactive compounds }{ }^{89,95} \& \text { stresses in large parts / bonds; (b) good } \\
\text { transparency \& high refractive index; (c) minimal leaching of toxic and radioactive components; (d) browning of } \\
\text { glass unimportant for tube part; shielding against X-rays required; (e) depending on application: high refractive } \\
\text { index, IR transparency, nonlinearity, luminescence efficiency; (f) conservation of transparency despite high } \\
\text { radiation doses. }\end{array}$} \\
\hline
\end{tabular}

Table 4. Representative materials / fillers used in conjunction with glass frits.

\begin{tabular}{|c|c|c|}
\hline Type & Application / function & Examples \\
\hline $\begin{array}{l}\text { Insulating } \\
\text { filler }\end{array}$ & $\begin{array}{l}\text { Dielectrics / enamels, sealing glasses, } \\
\text { encapsulation \& overglazes: CTE } \\
\text { adjustment of composite, glass } \\
\text { nucleating agent, reactive stabilisation, } \\
\text { colouring }\end{array}$ & $\begin{array}{l}\beta \text {-eucryptite, cordierite, zircon, mullite, } \\
\mathrm{PbTiO}_{3}, \mathrm{Al}_{2} \mathrm{O}_{3}, \mathrm{SiO}_{2} \text { (amorphous); } \\
\mathrm{NZP} \mathrm{family}^{147}{ }^{147} \mathrm{Fe}_{2} \mathrm{O}_{3}, \mathrm{SiO}_{2} \text { (quartz, } \\
\text { cristobalite); } ;{ }^{67-69,71} \mathrm{CaF}_{2} ; 154,165 \\
\mathrm{TiO}_{2} \dagger, \mathrm{MoO}_{3} \dagger\end{array}$ \\
\hline $\begin{array}{l}\text { Conducting } \\
\text { oxide }\end{array}$ & $\begin{array}{c}\text { Resistors: } \\
\text { conductive phase }^{61,62,156}\end{array}$ & $\begin{array}{c}\mathrm{RuO}_{2}, \mathrm{IrO}_{2} ;{ }^{157}(\mathrm{~Pb}, \mathrm{Bi}, \ldots)_{2} \mathrm{Ru}_{2} \mathrm{O}_{7-y} \\
(\mathrm{Ca}, \mathrm{Sr}, \mathrm{Ba}) \mathrm{RuO}_{3} ;{ }^{155} \mathrm{SnO}_{2}: \mathrm{Sb}^{166}\end{array}$ \\
\hline Metal & $\begin{array}{l}\text { TF conductors: conductive / solderable / } \\
\text { bondable phase }\end{array}$ & $\begin{array}{c}\mathrm{Ag}, \mathrm{AgPd}, \mathrm{Au}, \mathrm{Pt}, \mathrm{Ni}, \mathrm{Cu}^{60,64} \\
+ \text { other alloys }\end{array}$ \\
\hline $\begin{array}{l}\text { Bonding } \\
\text { oxides }\end{array}$ & $\begin{array}{l}\text { Thick-film conductors: fluxing \& } \\
\text { bonding to substrate }\end{array}$ & $\begin{array}{c}\mathrm{PbO}, \mathrm{Bi}_{2} \mathrm{O}_{3}, \mathrm{CuO}, \mathrm{ZnO}, \\
\mathrm{CdO} ;{ }^{60,64,158,159}(\mathrm{Ni}, \mathrm{Co}, \mathrm{Fe}) \mathrm{O}_{y}{ }^{160}\end{array}$ \\
\hline
\end{tabular}


Table 5. Qualitative composition $(+++=$ high, $++=$ medium, $+=$ low, $?=$ very low or absent) of commercial thick-film inks $\left(T_{f}=\right.$ firing temperature* $)$ : dielectrics ${ }^{167}$ (compared with LTCC $\left._{\dagger}\right){ }^{168-170}$ conductor $^{164}$ and resistor. ${ }^{85}$ Boron most likely present in all these compositions, but not always detectable by the analysis methods - mentioned where explicitly formulated / detected.

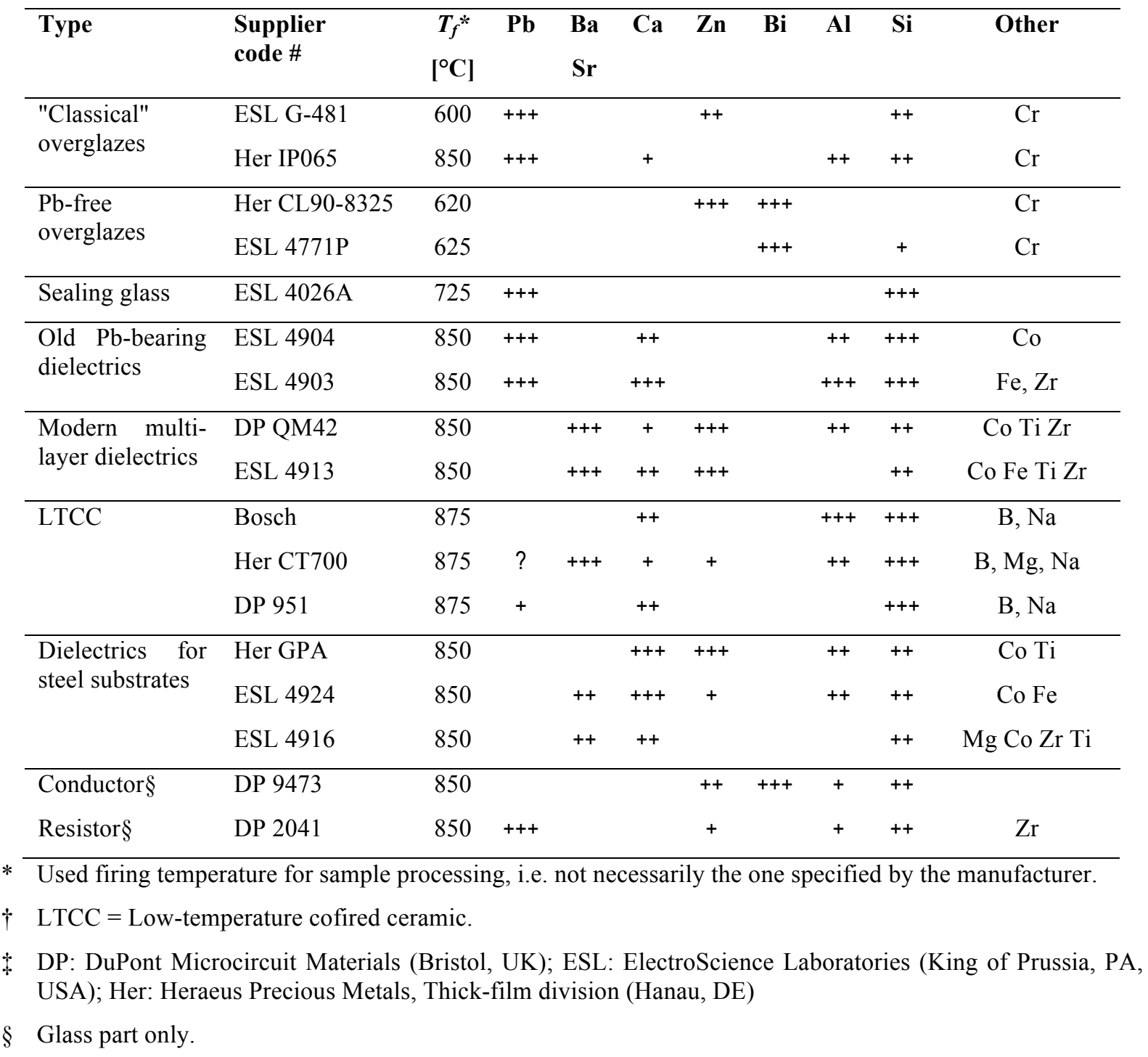




\subsection{The trend away from lead}

In recent times, there is a trend towards removing lead from electronic materials due to its toxicity (see supplement 11), a move spurred by the enactment of the European Union RoHS (Restriction of Hazardous Substances) directive. ${ }^{171}$ This has already largely taken place in the field of metallic solders, where the $\mathrm{Sn}-\mathrm{Ag}-\mathrm{Cu}$ alloy ("SAC") has become the standard to replace the classical $\mathrm{Sn}-\mathrm{Pb}-(\mathrm{Ag})$ eutectic. ${ }^{172}$ Although glasses in electronics are mentioned under the list of exemptions, ${ }^{173}$ the directive requires this list to be periodically reviewed in the future, and further restrictions on the use of lead-bearing glasses are therefore likely in the medium term. Moreover, cadmium, also a popular addition to low-melting glass frits, must be abandoned.

In contrast to the case of metallic lead and its simple, relatively soluble compounds such as litharge \& massicot $(\mathrm{PbO})$, minium $\left(\mathrm{Pb}_{3} \mathrm{O}_{4}\right)$ and ceruse $\left(2 \mathrm{PbCO}_{3} \cdot \mathrm{Pb}(\mathrm{OH})_{2}\right)$, lead in wellprepared glasses and glazes was traditionally considered to be stably bound, and therefore not a health concern, provided the composition was well formulated, and, for glazes, sufficiently fired. ${ }^{174}$ This perception drastically changed after the widely publicised 1991 work of Graziano \& Blum, ${ }^{175}$ who demonstrated that important amounts of lead could be leached out of "crystal" glass over time by (acidic) wines and spirits. This alarming report was later somewhat contradicted by more realistic tests, ${ }^{176}$ while other research ${ }^{177}$ showed that water dredged from $\mathrm{Pb}$-contaminated sediments remained well within the official limits, and, more to our point, that lead-bearing LTCC (low-temperature cofired ceramic) compositions could even exhibit good biocompatibility. ${ }^{178,179}$ However, although human exposure to lead and corresponding blood levels have drastically dropped in recent times, the ongoing controversy over the effects of low lead levels, especially for children, ${ }^{89}$ will likely generate additional regulatory pressure on its uses (see supplement 11). In the case of "crystal" glass, this has led to research activity towards lead-free substitutes, ${ }^{90}$ which showed that most of the properties of original "crystal" could be largely duplicated (although the working range was somewhat smaller), while guaranteeing minimal leaching of potentially dangerous substances.

The situation of glasses in electronics might seem less critical, due to the smaller volumes involved and to the fact that contact with foodstuffs or beverages is (usually) not specified. However, electronic glasses often require lower processing temperatures and only little or no alkali ions are tolerable when good insulating properties are required. Therefore, they can contain much higher amounts of lead than "crystal" ( $\geq 24 \%$ mass): ca. $65 \%$ for classical $850^{\circ} \mathrm{C}$-firing TFRs ${ }^{62}$ and up to ca. $85 \%$ mass for sealing glasses ${ }^{12,15,16,73,74,150}$ and low-firing TFRs $^{85,86}$ (Table 1). This results in much lower stability against dissolution in acids, ${ }^{140,141}$ which again raises the issue of contamination of groundwater from disposed electronics waste. Moreover, very low-temperature electronic encapsulant and sealing glasses may contain even more dangerous metals such as $\mathrm{Cd}$ and $\mathrm{Tl}^{165}$ Therefore, especially for these applications, alternative materials are needed. Finally, even if the final product may be considered stable, occupational exposure during processing is always a concern.

In thick-film electronics, removal of lead started in the 1980s with multilayer dielectrics, where traditional ceramic-filled glass formulations have given way to crystallisable types, which can be formulated lead-free. ${ }^{163}$ More recently there has been an effort to remove lead from frits in conductors, ${ }^{180}$ overglazes ${ }^{181}$ and sealing glasses, ${ }^{182}$ and commercial lead-free compositions have become widely available (see

Table 5). However, resistors (and to some extent sealing glasses and overglazes) have lagged behind in this trend, due to the exceptionally easy processing of lead-based glasses and the considerable development work required for entirely new TFR series. Lead-free glasses were widely used in the 1970s...1980s, including for resistors, due to the then considerable 
development of nitrogen-firing thick-film systems. ${ }^{183-189}$ However, these materials have largely fallen into disfavour, due mainly to performance and reliability problems, especially in ensuring proper organic vehicle burnout. ${ }^{190}$

While "lead-free" is an important aspect in the present review, glasses containing both $\mathrm{Bi}_{2} \mathrm{O}_{3}$ and $\mathrm{PbO}$ are also included, as they are relevant for specialised applications.

\section{Low-melting frits - alternative systems}

After the "classical" lead-based glasses (see previous sections), a short discussion of the potential oxide glass substitutes based on elements other than bismuth is given in this section. The reader is referred to other reviews for halide, chalcogenide (non-oxide) and chalcohalide glasses. $^{37,191-194}$

\subsection{Borate / borosilicate / silicate glasses}

Several glass systems have been proposed to replace lead-bearing frits. In the case of multilayer dielectrics for "standard" (firing at $850 \ldots 900^{\circ} \mathrm{C}$ ) thick-film technology, crystallising glasses containing mainly $\mathrm{CaO}-\mathrm{Al}_{2} \mathrm{O}_{3}-\mathrm{B}_{2} \mathrm{O}_{3}-\mathrm{SiO}_{2}$, forming phases such as anorthite or celsian, have largely displaced lead-bearing types in both screen-printed $850^{\circ} \mathrm{C}$ firing multilayer dielectrics ${ }^{163}$ and LTCC, $, 168,169$ with mostly improved performance, and therefore provide a satisfactory solution.

A complete lead-free cofireable TFR + LTCC system for processing at $900^{\circ} \mathrm{C}$ has been implemented by Bosch in its production of car ECUs (engine control units). ${ }^{169}$ This system is based on two glasses: an anorthite-crystallising $\mathrm{CaO}-\mathrm{Al}_{2} \mathrm{O}_{3}-\mathrm{B}_{2} \mathrm{O}_{3}-\mathrm{SiO}_{2}$ glass (as in the case of dielectrics), ${ }^{163}$ and a lower-melting $\mathrm{Na}_{2} \mathrm{O}-\mathrm{B}_{2} \mathrm{O}_{3}-\mathrm{SiO}_{2}$ one, which probably acts as a binder. In spite of its good properties, its extension to a general-purpose TFR system would be unlikely, as the complicated reactions involved in its processing require a very rigid and tightly controlled manufacturing process: as the resistor has a higher CTE than the substrate, it has to be co-fired with its overglaze, which imparts a protective compressive stress. Such very standardised processes may probably also be used by the chip resistor manufacturers to produce lead-free components.

There have been some attempts at making general-purpose TFRs based on similar glasses, with $\mathrm{RuO}_{2}{ }^{195-198}$ and ruthenate perovskites, ${ }^{197,199-202}$ or pyrochlores ${ }^{82,203}$ as conducting phases, which have partly resulted in promising properties, albeit with problems of high process sensitivity and the requirement of a large amount of - expensive - conducting $\mathrm{RuO}_{2}$.

The high encountered process sensitivity is expected, as these glasses tend to be not so "wellbehaved"29, 198, 204-207 as lead-based ones, which may be formulated to be virtually noncrystallising; ${ }^{45,73}$ the glass-forming range and stability of the lead-free glasses is in general more limited, and the processing range is restricted to relatively higher-temperature applications than for lead-bearing ones - or other properties such as CTE matching and durability are compromised. Therefore, the abovementioned lead-free glasses are not applicable to compositions requiring very low processing temperatures in applications such as low-firing TFR overglazes and sealing glasses in flat screens. ${ }^{206,207}$

Nevertheless, silicate, borosilicate or borophosphate glasses have found large-scale lowtemperature applications such as the overglazing of architectural and automobile glass ${ }^{34,46,47}$, and enamelling of aluminium. ${ }^{35,47,54-57,208}$ In these applications, the processing window between sufficient melting of the glass and degradation of the substrate is narrow, and firing schedules are tightly controlled, so a very wide stability range against crystallisation is not necessary. Moreover, significant amounts of alkali oxides, which are detrimental for insulator 
dielectric applications, are tolerated within the limits set by their detrimental effect on corrosion resistance; in enamels for aluminium, they impart a desirable high CTE to the glass.

\subsection{Phosphate glasses}

Phosphate glasses ${ }^{209,210}$ are an interesting alternative, as they usually have low working temperatures. On the other hand, high CTE and water absorption are potential issues. An example low-melting system is $\mathrm{Na}_{2} \mathrm{O}-\mathrm{Cu}_{2} \mathrm{O}-\mathrm{CuO}-\mathrm{P}_{2} \mathrm{O}_{5},{ }^{211}$ but chemical durability is only passable and it contains a high alkali content, limiting its use in electronics.

Many promising phosphate glasses are based on / derived from the $\mathrm{ZnO}-\mathrm{P}_{2} \mathrm{O}_{5}$ system, with additives such as $\mathrm{B}_{2} \mathrm{O}_{3}, \mathrm{SiO}_{2}, \mathrm{MgO}, \mathrm{CaO}, \mathrm{Al}_{2} \mathrm{O}_{3}, \mathrm{Fe}_{2} \mathrm{O}_{3}, \mathrm{~V}_{2} \mathrm{O}_{5}$ and $\mathrm{Nb}_{2} \mathrm{O}_{5} .{ }^{97,}{ }^{212-216}$ For instance, $\mathrm{Nb}_{2} \mathrm{O}_{5}$ additions were claimed to allow sealing glasses with processing temperatures as low as $500^{\circ} \mathrm{C}$, while retaining good durability and moderate CTE values. ${ }^{216}$ Explorative TFRs have also been formulated with such glasses, yielding, however, compatibility problems with Ag terminations. ${ }^{214,216}$ As in borosilicates, a good combination of low processing temperature, stability and durability is imparted by $\mathrm{PbO}$, and corresponding lead iron phosphate glasses have drawn interest for vitrification of high-level radioactive waste; avoidance of $\mathrm{PbO}$ is possible for this application if somewhat higher processing temperatures can be accepted. $6,95,97,98$

\subsection{Glasses based on divalent tin}

A major breakthrough towards low-melting phosphate frits was achieved with the SnO-ZnO$\mathrm{P}_{2} \mathrm{O}_{5}$ system. ${ }^{182,217} \mathrm{SnO}$, with $\mathrm{Sn}$ in the unusual +2 oxidation state, seems to behave in a similar manner as $\mathrm{PbO}$, without the toxicity problems. In fact, comparing simple binary $\mathrm{SnO}$, $\mathrm{PbO}$ and $\mathrm{ZnO}$ phosphate glasses, $\mathrm{SnO}$ gives the lowest glass transition temperatures, in the order $\mathrm{SnO}<\mathrm{PbO}<\mathrm{ZnO}^{218,219}$ Thus, $\mathrm{SnO}-\mathrm{ZnO}-\mathrm{P}_{2} \mathrm{O}_{5}$ glasses (with more $\mathrm{SnO}$ than $\mathrm{ZnO}$ ) can achieve flow characteristics similar to those of traditional lead-based frits ${ }^{182}$, while remaining lead- and alkali-free and having acceptable chemical durability. A recent review ${ }^{219}$ of SnObased glasses shows that low-melting properties are also found in tin(II) borate and silicate glasses, and, like $\mathrm{PbO}, \mathrm{SnO}$ allows very wide glass-forming ranges with the glass forming oxides, because it can partly behave as a glass former at high concentrations. Substituting part of the $\mathrm{O}^{2-}$ anions by $\mathrm{F}^{-}$or $\mathrm{Cl}^{-220,221}$ can further reduce processing temperatures (usually at the expense of durability, greatly improved by additions of none other than $\mathrm{Pb}),{ }^{153}$ while posing less migration problems than the alkali ions often present in other low-melting glass compositions.

Although these glasses seem very promising, there are issues about their rather large thermal expansion, ${ }^{182}$ mediocre adhesion to silicates such as float glass ${ }^{222}$ and mechanical properties. ${ }^{150}$ Moreover, the +2 valence state of $\mathrm{Sn}$, which is not stable in ambient air, raises two important processing issues. First, processing in air is preferable (cost \& burnout of the organic vehicle), but can oxidise $\mathrm{Sn}^{2+}$ to $\mathrm{Sn}^{4+}$, leading to devitrification and halting densification. This issue can be solved by replacing some of the $\mathrm{SnO}$ with low-valence oxides of transition metals such as $\mathrm{Mn}, \mathrm{Co}$ and $\mathrm{Fe}$, which would protect $\mathrm{Sn}^{2+}$ by acting as buffers that stabilise the oxygen activity in the glass to low values while being preferentially oxidised, as has been patented for $\mathrm{Mn}^{223}$ This, however, raises the second issue: such glasses, once they achieve densification, have a reducing character for anything they encapsulate, as evidenced by the tendency of $\mathrm{Cu}$ ions to be reduced to metal. ${ }^{219}$ Although this opens up interesting applications such as base-metal thick-films, compatibility with some applications such as existing $\mathrm{RuO}_{2} /$ ruthenate-based thick-film resistors will be problematic, due to likely reduction of the $\mathrm{Ru}$ compounds to metal $\left(2 \mathrm{SnO}+\mathrm{RuO}_{2} \rightarrow 2 \mathrm{SnO}_{2}+\mathrm{Ru}\right)$. Finally, the presence of metals in several coexisting valence states can degrade the insulating characteristics of 
dielectrics based on these glasses. ${ }^{224-228}$ One interesting open point relevant for this work is the possible substitution of $\mathrm{Pb}$ by $\mathrm{Bi}$ as an additive to achieve water-durable ultra low-melting tin fluorophosphate glasses, ${ }^{153,} 220$ i.e. whether $\mathrm{Bi}$ oxifluoride in glass is first at all thermodynamically compatible with $\mathrm{Sn}^{2+}$ (not reduced to metal) and, if this is the case, yields similar improvements in durability as $\mathrm{Pb}$ while maintaining a low processing temperature.

\subsection{Other systems}

Finally, other more "exotic" systems must be mentioned, such as glasses containing important amounts of $\mathrm{TeO}_{2}, \mathrm{~V}_{2} \mathrm{O}_{5}, \mathrm{Nb}_{2} \mathrm{O}_{5}, \mathrm{Ta}_{2} \mathrm{O}_{5}, \mathrm{MoO}_{3}$, and $\mathrm{WO}_{3}$, with $\mathrm{TeO}_{2}, \mathrm{~V}_{2} \mathrm{O}_{5}$, and $\mathrm{MoO}_{3}$ giving especially low-melting compositions. ${ }^{45,73,113,120,123,126,229-241}$ Although toxicity of $\mathrm{V}_{2} \mathrm{O}_{5}$ is a cause of concern (supplement 11), these oxides are useful as additives in small amounts, to improve adhesion, wetting and durability, suppress crystallisation in glasses and reduce working temperatures. ${ }^{35,56-58,146,198,207,216,222,242}$

\subsection{Discussion}

From the above considerations, one can conclude that replacement of lead-based frits by the abovementioned systems - of which several examples are summarised in Table 6 - may be achieved for applications not requiring a too demanding combination of good insulating properties (e.g. alkali-free), wide processing window, high durability and low processing temperatures; enamelling / overglazing aluminium and glass for protective, functional and decorative purposes, as well as TF dielectric and LTCC compositions, are good examples of successful large-scale replacement of lead-bearing glasses by borosilicate / silicate compositions. However, durability is often problematic if low processing temperatures are specified. $^{33}$

In electronics, mass-produced chip resistors and co-fired LTCC devices including resistors may also be manufactured lead-free using similar glasses. However, it would be difficult to achieve a general-purpose thick-film system with a comfortable processing window using these materials.

Phosphate and $\mathrm{SnO}$-based glasses, especially those derived from the $\mathrm{SnO}-\mathrm{ZnO}-\mathrm{P}_{2} \mathrm{O}_{5}$ system modified with transition metal oxides, are very promising, and their flow characteristics can resemble those of lead-based frits, but they represent a very radical departure from the heretofore-applied chemistry, especially due to their intrinsically reducing character. This may lead, through the likely resulting presence of mixed-valence transition metal oxides, to degradation of the insulating properties of dielectrics. Also, TFRs, currently based on (most likely incompatible) $\mathrm{RuO}_{2}$ would have to be formulated anew, using compatible conductive phases based on compounds such as reduced/doped $\mathrm{SnO}_{2}, \mathrm{Fe}_{3} \mathrm{O}_{4}, \mathrm{MoO}_{2}$ and $\mathrm{WO}_{2}$. Finally, the high water affinity of phosphate glasses ${ }^{209}$ is an issue which cannot be ignored if welldefined, high-reliability electronic materials are to be manufactured. 
Table 6. Some low-melting lead-free glass systems (without $B i$ ), with typical glass transition temperature $T_{g} . \mathrm{R}_{2} \mathrm{O}=(\mathrm{Li}, \mathrm{Na}, \mathrm{K})_{2} \mathrm{O} ; \mathrm{RO}=(\mathrm{Ca}, \mathrm{Sr}, \mathrm{Ba}, \mathrm{Zn}) \mathrm{O}$.

\begin{tabular}{|c|c|c|}
\hline System & $\begin{array}{c}T_{g} \\
{\left[{ }^{\circ} \mathrm{C}\right]}\end{array}$ & Applications \& notes \\
\hline $\mathrm{SnO}-\mathrm{SnF}_{2}-\mathrm{P}_{2} \mathrm{O}_{5}{ }^{220}$ & 180 & $\begin{array}{l}\text { Very low-temperature sealing, compatible } \\
\text { with organics } \\
\text { Poor durability; volatilisation; Sn(II) - see } \\
\text { below }\end{array}$ \\
\hline $\mathrm{SnO}-\mathrm{ZnO}-\mathrm{P}_{2} \mathrm{O}_{5}{ }^{182}$ & 300 & $\begin{array}{l}\text { Low-temperature sealing } \\
\mathrm{Sn}^{\mathrm{II}} \text { unstable in air \& incompatible with } \\
\mathrm{RuO}_{2}\end{array}$ \\
\hline $\begin{array}{l}\mathrm{ZnO}-\mathrm{Al}_{2} \mathrm{O}_{3}-\mathrm{SiO}_{2}-\mathrm{P}_{2} \mathrm{O}_{5}-\ldots{ }^{214} \\
\mathrm{R}_{2} \mathrm{O}-\mathrm{RO}-\mathrm{Al}_{2} \mathrm{O}_{3}-\mathrm{B}_{2} \mathrm{O}_{3}-\mathrm{SiO}_{2}{ }^{195,196,200,203} \\
\mathrm{RO}-\mathrm{Al}_{2} \mathrm{O}_{3}-\mathrm{B}_{2} \mathrm{O}_{3}-\mathrm{SiO}_{2}{ }^{82,197-199,201,202}\end{array}$ & $\begin{array}{l}\approx 400- \\
600\end{array}$ & $\begin{array}{l}\text { Experimental TFRs - high process } \\
\text { sensitivity \& other issues } \\
\text { Overglazes (TF, architecture, ...) }\end{array}$ \\
\hline$(\mathrm{ZnO}-) \mathrm{Fe}_{2} \mathrm{O}_{3}-\mathrm{P}_{2} \mathrm{O}_{5}^{6,97}$ & $\approx 500$ & $\begin{array}{l}\text { Nuclear waste immobilisation; higher } \\
\text { working temperature than } \mathrm{PbO}-\mathrm{Fe}_{2} \mathrm{O}_{3}-\mathrm{P}_{2} \mathrm{O}_{5} \text {, } \\
\text { but successful }\end{array}$ \\
\hline $\mathrm{R}_{2} \mathrm{O}-\mathrm{TiO}_{2}-\mathrm{SiO}_{2}-\mathrm{V}_{2} \mathrm{O}_{5}-\mathrm{P}_{2} \mathrm{O}_{5}{ }^{35,57,58}$ & & $\begin{array}{l}\text { Enamels for aluminium; toxic } \\
\mathrm{V}_{2} \mathrm{O}_{5} \text { (supplement 11) hard to remove }\end{array}$ \\
\hline $\begin{array}{l}\mathrm{BaO}-\mathrm{ZnO}-\mathrm{B}_{2} \mathrm{O}_{3}{ }^{206} \\
\mathrm{ZnO}-\mathrm{B}_{2} \mathrm{O}_{3}-\mathrm{MoO}_{3} / \mathrm{WO}_{3}{ }^{207}\end{array}$ & $\approx 500$ & $\begin{array}{l}\text { Relatively high working temperature; } \mathrm{BaO} \\
\text { somewhat toxic (supplement } 11 \text { ); limited } \\
\text { glass stability with } \mathrm{MoO}_{3} / \mathrm{WO}_{3} \text { additions }\end{array}$ \\
\hline $\begin{array}{l}\mathrm{CaO}-\mathrm{Al}_{2} \mathrm{O}_{3}-\mathrm{B}_{2} \mathrm{O}_{3}-\mathrm{SiO}_{2} \\
+\mathrm{Na}_{2} \mathrm{O}-\mathrm{B}_{2} \mathrm{O}_{3}-\mathrm{SiO}_{2}{ }^{243}\end{array}$ & $\begin{array}{l}\approx 650 \\
\approx 600\end{array}$ & $\begin{array}{l}\text { Duplex lead-free glass for resistors co-fired } \\
\text { with LTCC - fired at } 900^{\circ} \mathrm{C}\end{array}$ \\
\hline
\end{tabular}




\section{Bismuth glasses}

\subsection{Introduction}

In contrast to the abovementioned lead-free glasses, $\mathrm{Bi}_{2} \mathrm{O}_{3}$ appears a quite promising "dropin" replacement for $\mathrm{PbO}$, as also evidenced by comparing the commercial lead-free and leadbased thick-film overglazes (

Table 5). The intentional use of bismuth in glasses is by far not as old as that of lead (supplement 10), but the similarity of $\mathrm{Bi}_{2} \mathrm{O}_{3}$ and $\mathrm{PbO}$ was immediately noticed in the early studies; ${ }^{129,244-247}$ akin to $\mathrm{PbO}, \mathrm{Bi}_{2} \mathrm{O}_{3}$ belongs to the class of "conditional glass formers": while it does not by itself readily form a glass, it can be incorporated in very large quantities in the classical glass forming oxides $\mathrm{SiO}_{2}, \mathrm{~B}_{2} \mathrm{O}_{3}$ and $\mathrm{P}_{2} \mathrm{O}_{5}$ and $\mathrm{GeO}_{2},{ }^{2,110,245,246,248}$ where it acts as a glass modifier at low concentrations, but partly as a glass former at higher ones. These glasses may in turn incorporate, under standard glass-making conditions, large amounts of alkaline earth (especially $\mathrm{SrO}$ and $\mathrm{BaO}$ ) and transition metal oxides (e.g. $\mathrm{ZnO}, \mathrm{Fe}_{2} \mathrm{O}_{3}, \mathrm{CuO}_{y}, \mathrm{MnO}_{y}$, $\mathrm{CoO}_{y}$ ), as well as $\mathrm{PbO}$, with small additions enhancing vitrification. ${ }^{73,122,129,246,248-272}$ Other possible additives are alkalies ${ }^{247,248}$ and rare earths. ${ }^{273-278}$ Vitrification in different systems is detailed more fully in the following section (3.2). Representative compositions are given in Table 7, and a system-property reference index of studied systems is given in Table 8 for borates, Table 9 for silicates, germanates and phosphates, Table 10 for other systems and Table 11 for binary systems without network formers; systems with several network formers are attributed on a following priority basis: $\mathrm{B}_{2} \mathrm{O}_{3}, \mathrm{SiO}_{2}, \mathrm{GeO}_{2}, \mathrm{TeO}_{2}, \mathrm{~V}_{2} \mathrm{O}_{5}$ and $\mathrm{MoO}_{3}$.

One fortunate difference with lead is the much lower toxicity of bismuth, which compares well in this respect with other potential substitutes, as discussed in supplement 11. A less fortunate aspect, however, is the somewhat lower fluxing ability, as can be inferred from the higher overall bonding of $\mathrm{Bi}^{3+}$ vs. $\mathrm{Pb}^{2+}$ : simple substitution of $\mathrm{PbO}$ with " $\mathrm{BiO}_{1.5}$ " leads to higher processing temperatures, as illustrated by the stable liquidus (Figure 2) and glass transition temperatures $\left(T_{g}\right.$, Figure 3$)$. This may be seen as well on the ternary $\mathrm{PbO}-\mathrm{Bi}_{2} \mathrm{O}_{3^{-}}$ $\mathrm{B}_{2} \mathrm{O}_{3}$ phase diagram, ${ }^{279}$ where the ternary eutectic composition lies very close to the $\mathrm{PbO}$ $\mathrm{B}_{2} \mathrm{O}_{3}$ join, at ca. $45 \mathrm{~Pb}+4 \mathrm{Bi}+51 \mathrm{~B}$ on a cation basis. Therefore, most studies and developed low-melting glasses are based on the $\mathrm{Bi}_{2} \mathrm{O}_{3}-\mathrm{B}_{2} \mathrm{O}_{3}$ binary, which combines a wide vitrification range with relatively low processing temperatures, with $\mathrm{ZnO}, \mathrm{SiO}_{2}$ and $\mathrm{Al}_{2} \mathrm{O}_{3}$ being the most common additions. One must however note that comparison on the basis of equilibrium diagrams should be made with caution, given the slow equilibration in many $\mathrm{Bi}_{2} \mathrm{O}_{3}$-containing systems, attributed to mesomorphism in the melt ${ }^{280}$ and illustrated in corresponding metastable phase diagrams. ${ }^{280-282}$

Scientific work has been matched by technical use, the first patent dating from as early as 1945. ${ }^{283}$ In the early patents, ${ }^{49,87,146,283-288} \mathrm{Bi}_{2} \mathrm{O}_{3}$ was introduced in component / ceramic metallisations for its fluxing and wetting properties. The glass frits usually contained $\mathrm{PbO}$ and/or $\mathrm{CdO}$ - their elimination was at the time not an issue - and the patents gave conflicting information about how $\mathrm{Bi}_{2} \mathrm{O}_{3}$ should best be added to obtain maximal adhesion: included in the glass frit, "presintered" with it, added separately to the paste, or even be present both in the glass and as a separate addition. Ensuring good adhesion to alumina without any alkali oxides, $\mathrm{CdO}$ and $\mathrm{PbO}$ was reported to be problematic, but possible by replacing some $\mathrm{SiO}_{2}$ by $\mathrm{GeO}_{2}{ }^{288}$ Starting from 1980, a string of early Soviet patents, ${ }^{289-293}$ from what is now the Belarusian State Technological University, disclose a family of low-melting or intermediate glass frits based on the $\mathrm{ZnO}-\mathrm{Bi}_{2} \mathrm{O}_{3}-\mathrm{B}_{2} \mathrm{O}_{3}-\mathrm{SiO}_{2}$ system, with optional $\mathrm{Li}_{2} \mathrm{O}, \mathrm{Na}_{2} \mathrm{O}, \mathrm{MgO}, \mathrm{BaO}$, $\mathrm{CuO}$ and $\mathrm{CdO}, \mathrm{Al}_{2} \mathrm{O}_{3}$ additions, and claiming a better chemical resistance and a lower coefficient of thermal expansion (CTE) than analogous lead borosilicate frits. These glasses 
(Table 7-B80/B82/B83/B89), featuring moderate to high Bi content, processing temperatures down to ca. $500^{\circ} \mathrm{C}$, and designed specifically for application in electronics, overglazing and sealing, ${ }^{289-294}$ can truly be considered as the base for the "modern" Bi-based frits. More recent patents disclose usually similar compositions for glazes \& enamels, ${ }^{295-302} \mathrm{TF}$ conductors, ${ }^{250}$, 303-305 resistors $^{251}$ and overglazes, ${ }^{306,} 307$ plasma display panel (PDP) dielectrics, ${ }^{308}$ conductors $^{305,309,310}$ and low-melting sealing glasses. ${ }^{311-314}$

The closeness of $\mathrm{PbO}$ and $\mathrm{Bi}_{2} \mathrm{O}_{3}$ may be seen by comparing, on a cation basis, some glasses taken from Table 1 (standard \& low-fire resistor and non-crystallising sealing compositions) with corresponding Bi-based analogues (Table 7). Both types belong to the so-called "fragile glasses", i.e. with a strong dependence of properties on temperature around $T_{g}{ }^{253,315}$

Bi-based oxide glasses are already making strong inroads in commercial $\operatorname{architectural}^{33} \&$ automotive overglazes, ${ }^{48}$ as well as thick-film compositions (

Table 5). Besides these lead-free substitutes, $\mathrm{Bi}_{2} \mathrm{O}_{3}$-based $\mathrm{HMO}$ glasses have found potential applications - partly together with $\mathrm{PbO}$ - in nuclear physics (scintillators, gamma-ray shielding windows), ${ }^{129-135}$ optics, ${ }^{36,}$ 106-109, $111-128$ magnetic materials ${ }^{316}$ and glass-ceramic semi/superconductors. ${ }^{99-102}$ However, in spite of their significance, compositions based on $\mathrm{Bi}_{2} \mathrm{O}_{3}$ have drawn only scant attention - if mentioned at all - in classical "mainstream" reviews of glasses. ${ }^{2-6,20}$

\subsection{Glass formation}

A comparison of the vitrification ranges of $\mathrm{Bi}_{2} \mathrm{O}_{3}$ and $\mathrm{PbO}$ (and a few $\mathrm{SnO}$ examples) with common and uncommon glass formers, as found by various authors, is given in Table 12 for nominally binary systems, as a function of the estimated rate of cooling from the melt. This rate, indicated as a subscript for each limiting composition, is expressed in this work as a "quenching index" $Q$, equal to the base 10 logarithm of the estimated cooling rate:

$$
\left.Q=\log _{10} \text { (estimated cooling rate in } \mathrm{K} \mathrm{s}^{-1}\right)
$$

The reader is reminded that the indicated cooling rates are approximate at best, educated guesses at the worst; the method for estimating / determining $Q$ is discussed in supplement 14 . Please also refer to section 4.1 for stability upon re-heating, and to more extensive work on $\mathrm{PbO}_{-}{ }^{10-13,16,19}$ and $\mathrm{SnO}-$ based $^{219}$ glasses.

\section{Origins of discrepancies in indicated data}

As seen in Table 12, some values are clearly in conflict, as exemplified by studies on aircooled gram-size samples ${ }^{245}$ yielding a larger vitrification range than others on quenched ones. ${ }^{244}$ Partial volatilisation of some components, especially $\mathrm{PbO}, \mathrm{Bi}_{2} \mathrm{O}_{3}, \mathrm{~B}_{2} \mathrm{O}_{3}$ and $\mathrm{P}_{2} \mathrm{O}_{5}$, can account for some of these discrepancies, especially for quenching studies, which tend to involve small, open melts. Also, the large apparent discrepancy involving the extensive early work of Janakirama-Rao ${ }^{246}$ is tentatively attributed to the graphical representation; if $\mathrm{Bi}_{2} \mathrm{O}_{3}$ is taken as " $\mathrm{BiO}_{1.5}$ " (to make it comparable to the other oxides), a convention sometimes seen in the literature ${ }^{36,112}$ and used in the present review, their results become closer to that of other work.

This said, the by far most common cause of extended reported vitrification ranges can be traced to small but significant amounts of $\mathrm{SiO}_{2}, \mathrm{Al}_{2} \mathrm{O}_{3}$ and other impurities (in porcelain, fireclay, etc.) leached from crucibles, ${ }^{118,317}$ so some of the examined compositions are most likely not strictly binary. Therefore, the borate systems are marked in Table 12 by a cruciblespecific suffix (where specified) after the quenching index. 


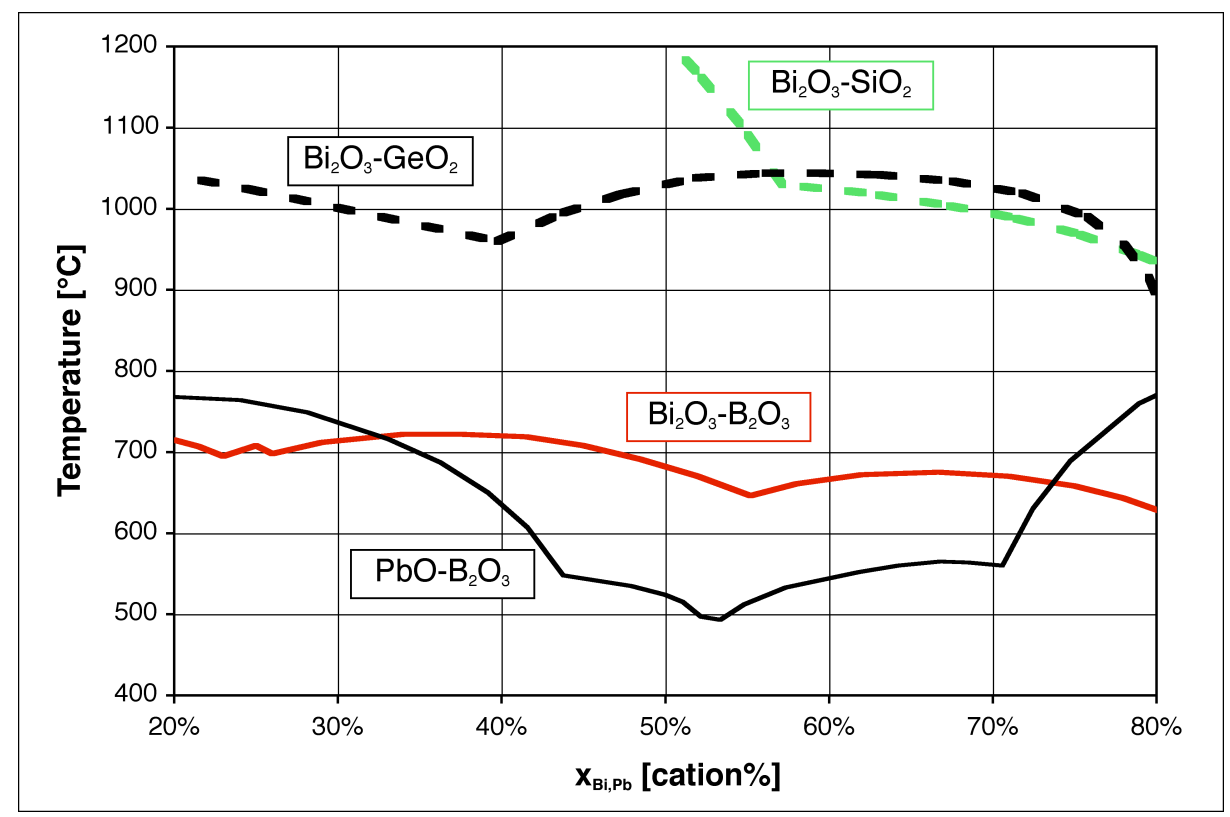

Figure 2. Liquidus temperatures of binary systems - redrawn from phase diagrams $\mathrm{Bi}_{2} \mathrm{O}_{3}-\mathrm{SiO}_{2},{ }^{281} \mathrm{Bi}_{2} \mathrm{O}_{3}-\mathrm{GeO}_{2} \quad(\mathrm{PDC}-2359), \quad \mathrm{Bi}_{2} \mathrm{O}_{3}-\mathrm{B}_{2} \mathrm{O}_{3} \quad(\mathrm{PDC}-323)$, and PbO$\mathrm{B}_{2} \mathrm{O}_{3}$ (PDC-282).

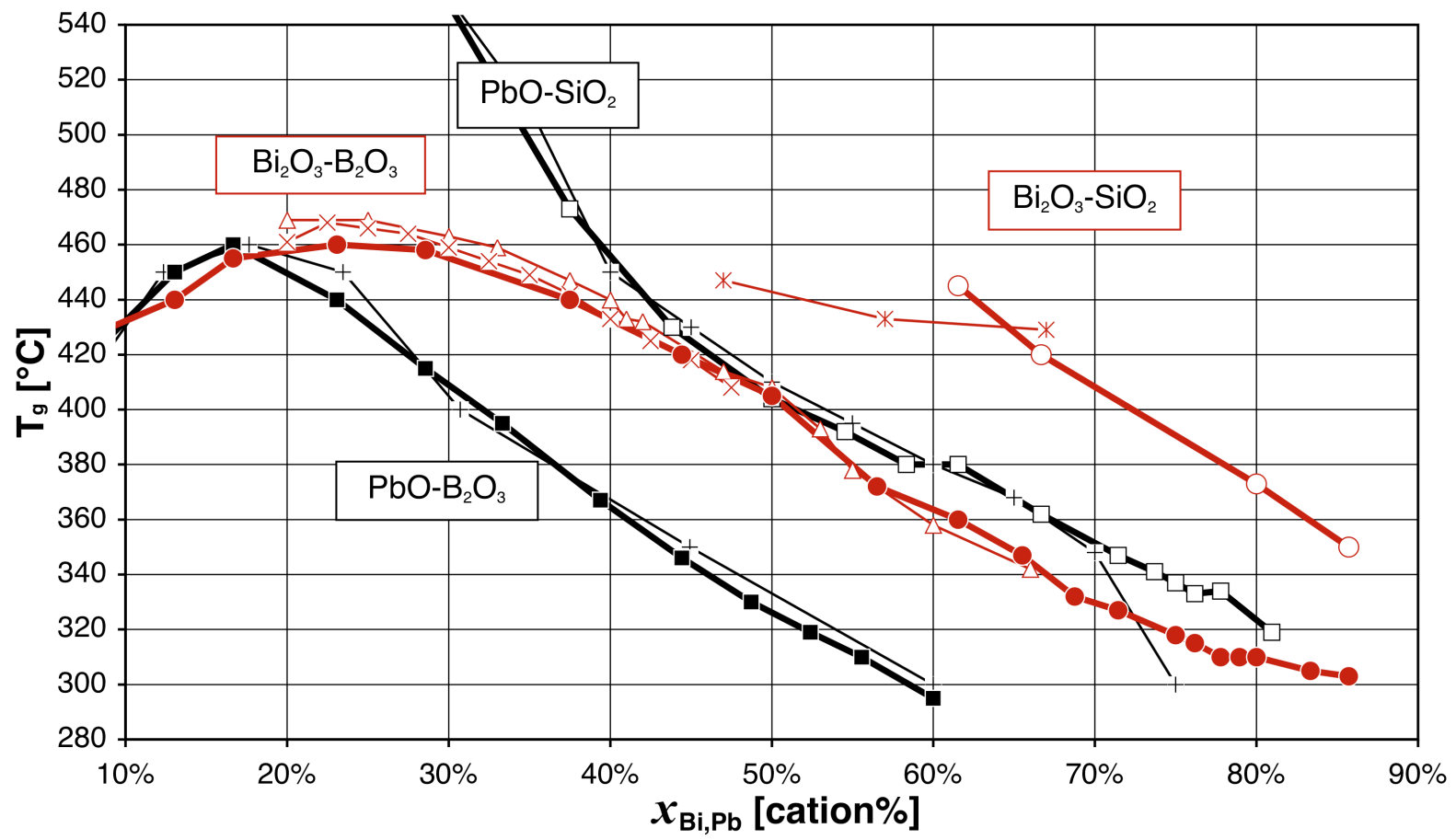

Figure 3. Glass transition temperatures $T_{g}$ of binary systems according to George et al. $^{248}$ (heavy lines), compared with other work $-\times^{318} \Delta^{317}+{ }^{141} *^{319}$ 
Table 7. Bismuth glass compositions, in cation mole\%.

\begin{tabular}{|c|c|c|c|c|c|c|c|}
\hline Code & $\begin{array}{c}\mathbf{Z n} \\
{[\%]}\end{array}$ & $\begin{array}{c}\mathbf{B i} \\
{[\%]} \\
\end{array}$ & $\begin{array}{c}\text { Al } \\
{[\%]}\end{array}$ & $\begin{array}{c}\text { B } \\
{[\%]} \\
\end{array}$ & $\begin{array}{c}\mathbf{S i} \\
{[\%]}\end{array}$ & $\begin{array}{l}\text { Other } \\
{[\%]}\end{array}$ & $\begin{array}{l}\text { Other } \\
{[\%]}\end{array}$ \\
\hline B80-1 & 11.8 & 44.2 & - & 38.7 & 5.3 & - & \multirow{3}{*}{$\begin{array}{l}\text { Early "stable" low-T } \\
\text { frits } \\
\mathrm{T}_{\mathrm{s}} \approx 405-435^{\circ} \mathrm{C}\end{array}$} \\
\hline B80-2 & 16.4 & 51.8 & - & 19.2 & 12.6 & - & \\
\hline B80-3 & 2.7 & 54.0 & - & 23.8 & 19.5 & - & \\
\hline B82-1 & 7.6 & 46.8 & 6.5 & 34.4 & 2.9 & $1.8 \mathrm{Mg}$ & \multirow{3}{*}{$\begin{array}{l}\mathrm{Mg}+\mathrm{Al}: \text { improved } \\
\text { durability }^{290}\end{array}$} \\
\hline B82-2 & 14.2 & 46.7 & 2.7 & 23.4 & 4.5 & $2.7 \mathrm{Mg}$ & \\
\hline B82-3 & 5.5 & 44.9 & 2.8 & 38.7 & 5.1 & $2.8 \mathrm{Mg}$ & \\
\hline B89-1 & 15.2 & 48.4 & - & 30.3 & 4.5 & $1.6 \mathrm{Ba}$ & \multirow{3}{*}{$\begin{array}{l}\text { Ba: improved } \\
\text { hardness } \\
\mathrm{T}_{\mathrm{s}} \approx 400^{\circ} \mathrm{C}\end{array}$} \\
\hline B89-2 & 18.4 & 48.5 & - & 24.7 & 6.9 & $1.6 \mathrm{Ba}$ & \\
\hline B89-3 & 8.8 & 47.0 & - & 35.4 & 7.4 & $1.3 \mathrm{Ba}$ & \\
\hline Don-01 & - & 34.1 & 13.4 & 30.7 & 21.8 & - & \multirow{2}{*}{ TFR overglaze 307} \\
\hline Don-04 & 5.2 & 36.3 & 20.7 & 18.2 & 19.5 & - & \\
\hline Fri-1 & 12.5 & 39.6 & 7.5 & 12.8 & 27.6 & & \multirow{2}{*}{$\begin{array}{l}\text { Overglaze } \\
1=' \mathrm{Zn}^{\prime} ; 2={ }^{\prime} \mathrm{ZnTi}^{\prime}\end{array}$} \\
\hline Fri-2 & 6.2 & 39.6 & 7.5 & 12.8 & 27.5 & $6.4 \mathrm{Ti}$ & \\
\hline $\mathrm{Hg}-010$ & 20.0 & 39.5 & 2.5 & 27.4 & 9.1 & $1.0 \mathrm{La}, 0.5 \mathrm{Gd}$ & \multirow{5}{*}{$\begin{array}{l}\text { Magnetic head } \\
\text { seals }^{314}\end{array}$} \\
\hline Hg-018 & 29.1 & 37.2 & 1.0 & 25.1 & 7.3 & $0.4 \mathrm{Ln} *$ & \\
\hline $\mathrm{Hg}-026$ & 15.0 & 56.5 & 2.4 & 16.5 & 2.1 & $0.1 \mathrm{Er}$ & \\
\hline $\mathrm{Hg}-071$ & 20.0 & 39.8 & 2.5 & 27.5 & 10.1 & $0.1 \mathrm{La}$ & \\
\hline Hg-141 & 21.0 & 42.0 & 1.0 & 26.8 & 4.5 & $4.2 \mathrm{Na}, 0.5 \mathrm{La}$ & \\
\hline $\mathrm{Hg}-203$ & 20.7 & 48.1 & 0.3 & 24.2 & 2.4 & $8.5 \mathrm{Na}$ & \multirow{2}{*}{ FPD seals ${ }^{314}$} \\
\hline Hg-324 & 20.6 & 52.3 & 0.6 & 21.5 & 2.7 & $1.1 \mathrm{Ca}, 1.0 \mathrm{Sr}$ & \\
\hline $\mathrm{Hm}-02$ & - & 82.4 & - & - & 17.6 & - & \multirow{7}{*}{$\begin{array}{l}\text { TFR frits, blended to } \\
\text { formulate resistive } \\
\text { composites }^{251}\end{array}$} \\
\hline $\mathrm{Hm}-03$ & - & 46.2 & - & - & 23.1 & $30.8 \mathrm{Cu}$ & \\
\hline $\mathrm{Hm}-04$ & 13.3 & 66.7 & - & - & 20.0 & - & \\
\hline $\mathrm{Hm}-05$ & - & 66.7 & - & - & 20.0 & $13.3 \mathrm{Cu}$ & \\
\hline $\mathrm{Hm}-06$ & 46.2 & - & - & - & 23.1 & $30.8 \mathrm{Co}$ & \\
\hline Hm-09 & 58.8 & - & - & - & 17.6 & $23.5 \mathrm{Fe}$ & \\
\hline $\mathrm{Hm}-11$ & 4.6 & 6.8 & 5.8 & 57.6 & 11.8 & $1.4 \mathrm{Mg}, 11.7 \mathrm{Ba}, 0.3 \mathrm{Cu}$ & \\
\hline
\end{tabular}


(Table 7. Bismuth glass compositions, in cation mole\%. - continued from previous page)

\begin{tabular}{|c|c|c|c|c|c|c|c|}
\hline Code & $\begin{array}{c}\mathbf{Z n} \\
{[\%]}\end{array}$ & $\begin{array}{c}\mathbf{B i} \\
{[\%]}\end{array}$ & $\begin{array}{c}\text { Al } \\
{[\%]}\end{array}$ & $\begin{array}{c}\text { B } \\
{[\%]}\end{array}$ & $\begin{array}{c}\mathbf{S i} \\
{[\%]}\end{array}$ & $\begin{array}{l}\text { Other } \\
{[\%]}\end{array}$ & $\begin{array}{l}\text { Note } \\
{[\%]}\end{array}$ \\
\hline $\mathrm{Hw}-0$ & 25.6 & 47.3 & 0.6 & 24.3 & 1.9 & $0.3 \mathrm{Ba}^{\dagger}$ & Conductor frit ${ }^{320}$ \\
\hline Нy-29 & 19.1 & 33.3 & 0.2 & - & 45.7 & $0.1 \mathrm{Mg}, 1.5 \mathrm{Ca}, 0.1 \mathrm{Cu}$ & $\begin{array}{l}\text { TFR overglaze } \\
\text { TFR matrix } \\
\text { TF2 }^{322}\end{array}$ \\
\hline Jeo-1 & 20.7 & 47.4 & 20.4 & 6.1 & - & $2.7 \mathrm{Na}, 2.7 \mathrm{Ag}$ & \multirow{2}{*}{$\mathrm{PV} \S^{53}$} \\
\hline Jeo-1' & 19.2 & 44.0 & 3.8 & 27.7 & - & $2.5 \mathrm{Na}, 2.7 \mathrm{Ag}$ & \\
\hline L-Bi08 & 10.0 & 45.0 & 4.0 & 35.0 & 6.0 & - & \multirow{6}{*}{$\begin{array}{l}\text { Experimental Bi- } \\
\text { based frits } \\
\text { (our work) }^{1,323}\end{array}$} \\
\hline L-Bi09 & 10.0 & 50.0 & 4.0 & 30.0 & 6.0 & - & \\
\hline L-Bi11 & 15.0 & 45.0 & 4.0 & 30.0 & 6.0 & - & \\
\hline L-Bi12 & 15.0 & 40.0 & 4.0 & 35.0 & 6.0 & - & \\
\hline L-Bi16 & 5.0 & 50.0 & 4.0 & 35.0 & 6.0 & - & \\
\hline L-Bi17 & 15.0 & 50.0 & 4.0 & 25.0 & 6.0 & - & \\
\hline LTS-1 & 10.6 & 25.1 & - & 17.8 & 1.4 & $\begin{array}{l}39.7 \mathrm{~Pb}, 3.2 \mathrm{Cu} \\
2.2 \mathrm{Fe}, 11 \mathrm{~F}_{2 \ddagger}\end{array}$ & \multirow{2}{*}{$\begin{array}{l}\text { Low-T sealing } \\
(+\mathrm{Pb}) \\
1: \mathrm{N} 14 ;^{149} 2: \mathrm{C}^{242}\end{array}$} \\
\hline LTS-2 & 5.9 & 4.5 & - & 28.2 & - & $\begin{array}{l}52.2 \mathrm{~Pb}, 2.8 \mathrm{Cu}, 4.7 \mathrm{Fe} \\
1.4 \mathrm{Te}, 0.3 \mathrm{Mn}, 3 \mathrm{~F}_{2} \ddagger\end{array}$ & \\
\hline Lvx-1 & - & 6.2 & - & 7.7 & 25.6 & $\begin{array}{l}38.4 \mathrm{Na}, 2.9 \mathrm{~K}, 4.5 \mathrm{Li} \\
0.9 \mathrm{Ba}, 13.7 \mathrm{Ti}\end{array}$ & Enamel for $\mathrm{Al}^{56}$ \\
\hline Nch-1 & 16.1 & 43.8 & - & 35.5 & 2.0 & $2.7 \mathrm{Sr}$ & $\mathrm{FPD} \mathrm{Seal}^{312}$ \\
\hline Rad-1 & - & 15.2 & - & - & 29.4 & $55.4 \mathrm{~Pb}$ & \multirow{3}{*}{$\begin{array}{l}\gamma \text {-ray shielding } \\
\text { 1: } \# 211,2: \# 218^{129} \\
\text { 3:\#14 }\end{array}$} \\
\hline Rad-2 & - & 21.3 & - & - & 16.5 & $62.2 \mathrm{~Pb}$ & \\
\hline Rad-3 & - & 73.7 & - & 21.1 & - & $5.3 \mathrm{~Pb}$ & \\
\hline Sck-30 & 30.6 & 8.2 & - & 61.2 & - & - & Early Zn-Bi-B ${ }^{73}$ \\
\hline Smt-7 & - & 64.5 & - & 33.3 & 2.1 & $0.1 \mathrm{Ce}$ & NL optics ${ }^{112}$ \\
\hline Usu-05 & 17.7 & 59.0 & - & 23.0 & - & $0.3 \mathrm{Ce}$ & \multirow{5}{*}{$\begin{array}{l}\text { FPD seal } \\
\text { "Si-free" }\end{array}$} \\
\hline Usu-06 & 20.6 & 54.4 & - & 24.6 & - & - & \\
\hline Usu-09 & 11.3 & 60.7 & - & 27.7 & - & - & \\
\hline Usu-10 & 17.6 & 52.5 & - & 29.6 & - & - & \\
\hline Usu-11 & 20.7 & 48.3 & - & 30.7 & - & - & \\
\hline
\end{tabular}

*Ln = lanthanide mix.

†Only sum $\mathrm{Si}+\mathrm{Al}+\mathrm{Ba}$ given in reference - "educated guess" according to Table 18.

†luorine expressed as replaced oxygen fraction, i.e. $\mathrm{F}_{2} /\left(\mathrm{O}+\mathrm{F}_{2}\right)$; usually inaccurate due to volatilisation losses.

$\S$ Possible error in paper - bottom formulation more likely. 
Table 8. System-property index: borates

\begin{tabular}{|c|c|}
\hline Oxide system & Properties* \\
\hline $\mathrm{Bi}-\mathrm{B}$ & $\begin{array}{l}\mathrm{P}^{282,318} \mathrm{~V}^{110,244,245,247,270,315,317,318,324,325} \mathrm{~S}^{247,254,317,326,327} \mathrm{~T}_{\mathrm{g}}^{110,248,275,315,317,318} \\
\mathrm{~T}_{\mathrm{s}}^{254,324} \mathrm{~T}_{\mathrm{x}}^{110,275,317,318,326} \alpha^{254,318,324} \rho^{110,248,254,315,317,318,324,327-329} \mathrm{n}^{318,324,325,327,329-331} \\
\mathrm{E}+\eta^{315} \mathrm{~m}^{317,327} \mathrm{~N}^{332} \mathrm{~L}^{325,329,331} \varepsilon^{324} \sigma^{328} \mathrm{~W}^{110,247,254,317,327,331,332} \mu^{132,133,254,333} \gamma^{143}\end{array}$ \\
\hline Li-Bi-B & $\mathrm{V}^{247,248,334,335} \mathrm{~S}+\mathrm{n}+\mathrm{W}^{334,335} \rho^{248,334,335}$ \\
\hline Li-K-Bi-B-V & $\mathrm{S}+\mathrm{T}_{\mathrm{g}}+\rho+\mathrm{W}^{336}$ \\
\hline Li-Zn-Bi-B & $\mathrm{S}+\mathrm{V}+\mathrm{W}+\rho+\sigma^{337,338} \mathrm{~T}_{\mathrm{g}}+\mathrm{W}+\mathrm{R}^{337}$ \\
\hline Li-Cd-Bi-B & $\mathrm{S}+\mathrm{W}+\rho+\sigma^{338}$ \\
\hline Na-Bi-B & $\mathrm{V}+\mathrm{S}+\mathrm{W}^{247}$ \\
\hline Na-Bi-Fe-B & $\mathrm{V}+\mathrm{X}+\mathrm{T}_{\mathrm{g}}+\mathrm{T}_{\mathrm{x}}+\sigma^{339}$ \\
\hline Na-Bi-B-Mo & $\mathrm{n}+\mathrm{W}^{340^{8}}+a^{2}$ \\
\hline K-Bi-B & $\mathrm{V}^{247}$ \\
\hline $\mathrm{K}-\mathrm{Bi}-\mathrm{Fe}-\mathrm{B}$ & $\mathrm{V}+\rho+\sigma^{341-343} \mathrm{~T}_{\mathrm{g}}^{343}$ \\
\hline Mg-Bi-B & $\mathrm{P}^{344}$ \\
\hline Ca-Bi-B & $\mathrm{P}^{345} \mathrm{Tg}+\mathrm{Tx}+\varepsilon^{+}+\sigma^{269}$ \\
\hline Sr-Bi-B & $\mathrm{P}^{346} \mathrm{~V}^{246,258,346} \mathrm{~W}+\rho+\sigma^{258}$ \\
\hline Ba-Bi-B & $\mathrm{P}^{347,348} \mathrm{~V}^{246,258,270,349} \mathrm{~S}^{266,349,350} \mathrm{~T}_{\mathrm{g}}^{349} \mathrm{~T}_{\mathrm{x}}{ }^{349} \mathrm{E}+\mathrm{H}^{266} \mathrm{~W}+\rho^{258,266,349,350} \sigma^{258} S+N^{351}$ \\
\hline Ba-Zn-Bi-Al-B-Sb & $\alpha+T_{g}+T_{s}+T_{x}+W+\sigma^{271}$ \\
\hline Pb-Bi-B & $\mathrm{P}^{279} \mathrm{~V}^{246,253,259,261} \mathrm{R}+\mathrm{S}^{352} \mathrm{~S}+\mathrm{W}+\mathrm{T}_{\mathrm{s}}+\alpha^{254} \mathrm{~T}_{\mathrm{g}}^{253,259,261,352} \mathrm{E}^{253,259,261} \mathrm{H}^{253} \rho^{130,254,259,261,352} \mu^{130}$ \\
\hline $\mathrm{Pb}-\mathrm{Bi}-\mathrm{B}-\mathrm{Si} \dagger$ & $\mathrm{W}+\mathrm{L}^{353}$ \\
\hline $\mathrm{Pb}-\mathrm{Zn}-\mathrm{Bi}-\mathrm{B}-\mathrm{Si}$ & $\mathrm{S}+\mathrm{X}+\mathrm{T}_{\mathrm{s}}+\alpha+\mathrm{H}+\mathrm{W}+\rho^{256}$ \\
\hline $\mathrm{Zn}-\mathrm{Bi}-\mathrm{B}+$ & $\mathrm{P}^{354} \mathrm{~V}^{122,246,264} \mathrm{~S}^{122,264,266,355} \mathrm{~T}_{\mathrm{g}}^{260,355} \mathrm{~m}+\alpha+\mathrm{s}+\varepsilon^{355} \mathrm{E}+\mathrm{H}^{266} \mathrm{~W}+\rho^{122,264,266} \mathrm{R}^{122}$ \\
\hline $\mathrm{Zn}-\mathrm{Bi}-\mathrm{B}-\mathrm{Si}$ & $\mathrm{V}+\alpha^{257,289,314} \mathrm{~T}_{\mathrm{g}}^{257} \mathrm{~T}_{\mathrm{s}}^{257,289,293} \mathrm{D}^{289} \mathrm{H}^{293} \sigma^{289,293}$ \\
\hline Zn-Bi-B-Si-Ba & $\alpha+T_{s}+T_{x}+H+D+\sigma^{293}$ \\
\hline Zn-Bi-Fe-B & 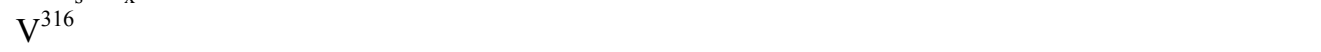 \\
\hline Zn-Bi-Al-B-Sb & $\alpha+T_{\mathrm{g}}+\mathrm{T}_{\mathrm{s}}+\mathrm{T}_{\mathrm{x}}+\mathrm{W}+\sigma^{271}$ \\
\hline $\mathrm{Cu}-\mathrm{Bi}-\mathrm{B}$ & $\mathrm{P}^{356} \mathrm{~V}^{132,249} \mathrm{~T}_{\mathrm{g}}+\mathrm{T}_{\mathrm{s}}+\alpha+\rho^{132,249} \mathrm{~T}_{\mathrm{x}}+\mathrm{D}+\mathrm{H}+\varepsilon^{+} \sigma^{249} \mathrm{~S}+\mathrm{W}+\mathrm{R}+\mu^{132}$ \\
\hline Y-Bi-B & $\mathrm{V}+\mathrm{S}+\mathrm{p}+\mathrm{W}^{274}$ \\
\hline La-Bi-B & $\mathrm{T}_{\mathrm{g}}+\mathrm{T}_{\mathrm{x}}+\alpha+\mathrm{H}+\rho^{275}$ \\
\hline Sm-Bi-B & $\mathrm{X}+\mathrm{T}_{\mathrm{g}}+\mathrm{T}_{\mathrm{x}}+\mathrm{L}^{273}$ \\
\hline Eu-Bi-B & $\mathrm{X}+\mathrm{S}+\mathrm{W}^{276,357} \rho^{357}$ \\
\hline Eu-Bi-Al-B & $\mathrm{V}+\mathrm{S}+\mathrm{T}_{\mathrm{g}}+\mathrm{T}_{\mathrm{x}}+\mathrm{W}^{277}$ \\
\hline Gd-Bi-Al-B & $\mathrm{V}+\mathrm{S}+\mathrm{W}^{278}$ \\
\hline Gd-Bi-B-Mo & $\mathrm{V}+\mathrm{S}+\rho+\mathrm{E}+\mathrm{H}+\mathrm{n}+\mathrm{W}^{358}$ \\
\hline Er-Bi-B & $\mathrm{T}_{\mathrm{g}}+\mathrm{T}_{\mathrm{x}}+\alpha+\mathrm{H}+\rho^{275}$ \\
\hline Bi-Fe-B & $\mathrm{V}+\mathrm{T}_{\mathrm{g}}^{252} \mathrm{~T}_{\mathrm{s}}+\mathrm{T}_{\mathrm{x}}+\varepsilon^{272} \mathrm{~W}^{255,272} \rho+\sigma^{252,272} \mathrm{~S}+\mathrm{X}+W+\mathrm{R}+R^{255}$ \\
\hline Bi-Ga-B & $\mathrm{S}+\mathrm{T}_{\mathrm{g}}+\mathrm{T}_{\mathrm{x}}+\mathrm{R}^{359,360} \mathrm{n}+\mathrm{W}+\rho^{119,359,360} \mathrm{~L}^{119}$ \\
\hline Bi-B-Si & $\mathrm{V}^{112,263,361,362} \mathrm{~S}^{362} \mathrm{~T}_{\mathrm{g}}+\mathrm{T}_{\mathrm{x}}^{263,362} \mathrm{~W}^{112,361,362} \mathrm{n}^{112,362} \mathrm{~N}^{112} \mathrm{R}^{362}$ \\
\hline $\mathrm{Bi}-\mathrm{B}-\mathrm{Ti}$ & $\mathrm{V}+\mathrm{T}_{\mathrm{g}}+\mathrm{T}_{\mathrm{x}}^{363}$ \\
\hline $\mathrm{Bi}-\mathrm{B}-\mathrm{Ti}-\mathrm{Nb}$ & $\mathrm{V}+\mathrm{X}+\mathrm{T}_{\mathrm{g}}+\mathrm{T}_{\mathrm{x}}+\varepsilon^{364}$ \\
\hline
\end{tabular}

*P: phase diagram; V: vitrification; S: structure; X: crystallisation (see also $\mathrm{T}_{\mathrm{x}}$ ); b: Mössbauer spectroscopy; $\mathrm{m}$ : nuclear magnetic resonance (NMR); p: electron paramagnetic/spin resonance (EPR/ESR); s: sintering; $\mathrm{T}_{\mathrm{g}}$ : glass transition temperature; $\mathrm{T}_{\mathrm{s}}$ : softening point; $\mathrm{T}_{\mathrm{x}}$ : crystallisation temperature; $\alpha$ : CTE; c: heat capacity; E: elasticity; $\eta$ : viscosity; $\rho$ : density; $\gamma$ : surface tension; D: chemical durability; $\mathrm{H}$ : hardness and/or strength; $\mathrm{n}$ : refraction index; W: optical transmission; $\mathrm{N}$ : optical nonlinearity; L: luminescence/ amplification/ upconversion; R: Raman spectra; $\varepsilon$ : dielectric properties; $\sigma$ : electrical conductivity; $\mu$ : interaction with ionising radiation.

$\dagger$ Also + Sb fining agent.

†rror in Kim et al. ${ }^{260}-T_{g} / T_{\text {liquidus }} \approx 2 / 3$, authors used ${ }^{\circ} \mathrm{C}$ instead of $\mathrm{K}$. 
Th. Maeder - IMR 2012 - Review of $\mathrm{Bi}_{2} \mathrm{O}_{3}$-based glasses (9.10.2012) - 21

Table 9. System-property index: silicates, germanates \& phosphates.

\begin{tabular}{|c|c|}
\hline Oxide system & Properties (symbols: see Table 8 ) \\
\hline $\mathrm{Bi}-\mathrm{Si}$ & $\mathrm{P}^{281,365} \mathrm{~V}^{107,131,244,245} \mathrm{~S}+\mathrm{T}_{\mathrm{s}}+\mathrm{W}+\mathrm{R}+\mu^{131} \mathrm{~T}_{\mathrm{g}}{ }^{131,248,319} \mathrm{~T}_{\mathrm{x}}{ }^{366} \rho^{248,319,329} \mathrm{n}^{329} \sigma^{319,366}$ \\
\hline $\mathrm{K}-\mathrm{Bi}-\mathrm{Si}$ & $\mathrm{T}_{\mathrm{x}}+\sigma^{366}$ \\
\hline $\mathrm{Pb}-\mathrm{Bi}-\mathrm{Si}$ & $\mathrm{V}+\rho+\mu^{129} \rho+\mathrm{H}+\mathrm{W}^{367}$ \\
\hline $\mathrm{Bi}-\mathrm{Si}-\mathrm{Ti}-\mathrm{Nb}$ & $\mathrm{V}+\mathrm{X}+\mathrm{T}_{\mathrm{g}}+\mathrm{T}_{\mathrm{x}}+\varepsilon^{364}$ \\
\hline $\mathrm{Bi}-\mathrm{Ge}$ & $\mathrm{P}^{280} \mathrm{~V}^{231,245} \mathrm{~T}_{\mathrm{g}}{ }^{319} \mathrm{~T}_{\mathrm{x}}{ }^{366,368} \rho^{319,329} \mathrm{~W}^{231,368} \mathrm{n}^{329} \sigma^{319,366}$ \\
\hline $\mathrm{Bi}-\mathrm{Ge}-\mathrm{V}$ & $\mathrm{V}+\mathrm{W}^{231}$ \\
\hline K-Bi-Ge & $T_{x}+\sigma^{366}$ \\
\hline $\mathrm{Pb}-\mathrm{Bi}-\mathrm{Ge}$ & $\mathrm{V}+\rho+\alpha+\mathrm{T}_{\mathrm{g}}+\mathrm{T}_{\mathrm{x}}{ }^{369}$ \\
\hline Pb-Bi-Ga-Ge & $\mathrm{T}_{\mathrm{g}}+\mathrm{T}_{\mathrm{x}}^{121} \mathrm{~W}+\mathrm{L}^{121,125,370} \mathrm{R}^{370}$ \\
\hline $\mathrm{Pb}-\mathrm{Bi}-\mathrm{Ga}-\mathrm{Ge}-\mathrm{F}^{*}$ & $\mathrm{~T}_{\mathrm{g}}+\mathrm{T}_{\mathrm{x}}+\mathrm{R}+\mathrm{L}^{371}$ \\
\hline Zn-Bi-Ge & $\mathrm{V}+\rho+\mathrm{D}+\mathrm{W}^{372}$ \\
\hline $\mathrm{Bi}-\mathrm{Cr}-\mathrm{Ge}$ & $\mathrm{V}+\mathrm{S}+\mathrm{p}^{373}$ \\
\hline Eu-Bi-Ge & $\mathrm{V}+\mathrm{S}+\mathrm{W}^{374}$ \\
\hline $\mathrm{Bi}-\mathrm{P}$ & $\mathrm{V}^{244,375,376} \rho^{329,375,376} \alpha+\mathrm{T}_{\mathrm{g}}+\mathrm{T}_{\mathrm{x}}+\mathrm{D}+\mathrm{W}^{375} \mathrm{E}^{376} \mathrm{n}^{329,375} \mathrm{P}^{377}$ \\
\hline Bi-Fe-P & $\mathrm{S}+\mathrm{b}+\rho+\sigma+\varepsilon^{228}$ \\
\hline Li-Bi-P & $\mathrm{V}+\mathrm{T}_{\mathrm{g}}+\rho+\mathrm{W}^{378}$ \\
\hline Zn-Bi-P & $\mathrm{V}+\mathrm{S}+\mathrm{T}_{\mathrm{g}}+\rho^{262,265,267} \alpha^{265} \mathrm{~m}+\mathrm{T}_{\mathrm{x}}+\mathrm{R}^{262} \mathrm{~W}^{265,267} \mathrm{D}^{262,267}$ \\
\hline
\end{tabular}

Table 10. System-property index: tellurites, vanadates, molybdates \& other*.

\begin{tabular}{|c|c|}
\hline Oxide system & Properties (symbols: see Table 8) \\
\hline $\mathrm{Bi}-\mathrm{Te}$ & $\mathrm{P}^{379} \mathrm{~V}^{244,245}$ \\
\hline Bi-Te-Ti & $\mathrm{P}^{380} \mathrm{~V}+\mathrm{S}+\mathrm{T}_{\mathrm{g}}+\mathrm{T}_{\mathrm{x}}+\mathrm{R}+\rho^{240}$ \\
\hline $\mathrm{Bi}-\mathrm{Te}-\mathrm{Nb}$ & $\mathrm{V}+\mathrm{X}+\mathrm{T}_{\mathrm{g}}+\mathrm{T}_{\mathrm{x}}+\rho^{113}$ \\
\hline Bi-Te-W & $\mathrm{V}+\mathrm{W}+\rho^{123,126} \mathrm{~S}+\mathrm{T}_{\mathrm{g}}+\alpha+\mathrm{R}+\rho^{126} \mathrm{n}+\mathrm{N}^{123}$ \\
\hline $\mathrm{Ba}-\mathrm{Bi}-\mathrm{Te}$ & $\mathrm{V}+\mathrm{S}+\mathrm{T}_{\mathrm{g}}+\mathrm{T}_{\mathrm{x}}+\alpha+\mathrm{n}+\mathrm{W}+\mathrm{R}^{120}$ \\
\hline Zn-Bi-Te & $\mathrm{V}+\mathrm{n}+\mathrm{W}+\mathrm{N}+\rho^{241}$ \\
\hline Bi-Te-V & $\mathrm{Tg}+\mathrm{E}+\rho^{239}$ \\
\hline $\mathrm{Pb}-\mathrm{Bi}-\mathrm{Te}-\mathrm{V}$ & $\mathrm{Ts}+\alpha+\sigma+\varepsilon^{45}$ \\
\hline $\mathrm{Bi}-\mathrm{V}$ & $\mathrm{V}^{231,238,244} \mathrm{~T}_{\mathrm{g}}+\mathrm{T}_{\mathrm{x}}+\rho^{238} \mathrm{~W}^{231}$ \\
\hline $\mathrm{Bi}-\mathrm{Fe}-\mathrm{V}$ & $\mathrm{V}+\mathrm{S}+\mathrm{b}+\mathrm{T}_{\mathrm{g}}+\mathrm{T}_{\mathrm{s}}+\mathrm{T}_{\mathrm{x}}+\mathrm{W}^{233}$ \\
\hline $\mathrm{Bi}-\mathrm{Fe}-\mathrm{Mo}$ & $\mathrm{V}+\mathrm{S}+\mathrm{b}+\mathrm{T}_{\mathrm{g}}+\mathrm{T}_{\mathrm{s}}+\mathrm{T}_{\mathrm{x}}+\mathrm{W}^{234}$ \\
\hline Bi-V-Mo & $\mathrm{V}+\mathrm{T}_{\mathrm{g}}+\mathrm{T}_{\mathrm{x}}^{232,235} \mathrm{~S}^{232}$ \\
\hline $\mathrm{Pb}-\mathrm{Bi}-\mathrm{Mo}$ & $\mathrm{V}+\mathrm{X}+\mathrm{W}^{115}$ \\
\hline $\mathrm{Li}-\mathrm{Ba}-\mathrm{Bi}$ & $\mathrm{V}+\mathrm{T}_{\mathrm{g}}+\mathrm{T}_{\mathrm{x}}+\mathrm{W}^{381}$ \\
\hline $\mathrm{Li}-\mathrm{Pb}-\mathrm{Bi}$ & $\mathrm{V}+\mathrm{T}_{\mathrm{g}}+\mathrm{T}_{\mathrm{x}}+\rho+\mathrm{W}^{382}$ \\
\hline $\mathrm{Ca}-\mathrm{Sr}-\mathrm{Pb}-\mathrm{Cu}-\mathrm{Bi}$ & $\mathrm{X}+\sigma^{\mathrm{i} 04}$ \\
\hline $\mathrm{Sr}-\mathrm{Pb}-\mathrm{Bi}$ & $\mathrm{W}+\mathrm{L}^{117}$ \\
\hline $\mathrm{Pb}-\mathrm{Ba}-\mathrm{Zn}-\mathrm{Bi}$ & $\mathrm{V}+\rho+\mathrm{n}+\mathrm{W}^{36}$ \\
\hline $\mathrm{Pb}-\mathrm{Cd}-\mathrm{Bi}-\mathrm{Fe}$ & $\mathrm{V}+\mathrm{T}_{\mathrm{g}}+\alpha+\rho+\mathrm{n}+\mathrm{W}+\sigma+\varepsilon^{36}$ \\
\hline $\mathrm{Pb}-\mathrm{Cu}-\mathrm{Bi}$ & $\mathrm{P}^{383} \mathrm{~V}+\mathrm{S}+\mathrm{T}_{\mathrm{g}}+\mathrm{T}_{\mathrm{x}}+\mathrm{W}^{103}$ \\
\hline $\mathrm{Pb}-\mathrm{Bi}-\mathrm{Mn}-\left[\mathrm{Al}^{\#}\right]$ & $\mathrm{S}+\mathrm{W}+\mathrm{R}^{384}$ \\
\hline $\mathrm{Pb}-\mathrm{Bi}-\mathrm{Ga}$ & $\mathrm{V}^{36,128} \alpha+\sigma+\varepsilon^{36} \mathrm{~S}^{111,371,385,386} \mathrm{R}^{371,385,386} \mathrm{~L}^{127,371} \rho+\mathrm{n}+\mathrm{W}^{36,128,387} \mathrm{~T}_{\mathrm{g}}+\mathrm{T}_{\mathrm{x}}{ }^{371,387}$ \\
\hline
\end{tabular}

*Binary systems without glass formers: see Table 11. \#Probable $\mathrm{Al}_{2} \mathrm{O}_{3}$ contamination from crucible. 
Th. Maeder - IMR 2012 - Review of $\mathrm{Bi}_{2} \mathrm{O}_{3}$-based glasses (9.10.2012) - 22

Table 11. Glasses without standard network formers: binary systems.

\begin{tabular}{|c|c|c|c|c|}
\hline \multirow{2}{*}{\begin{tabular}{|l|l}
$\begin{array}{l}\text { Oxide } \\
\text { system }\end{array}$ \\
Bi-Li \\
\end{tabular}} & \multicolumn{3}{|c|}{ Range* (\%left cation) $^{2}$} & \multirow{2}{*}{$\begin{array}{l}\text { Properties (symbols: see Table } 8 \text { ) } \\
\mathrm{V}^{381,388,389} \mathrm{~T}_{\mathrm{g}}+\mathrm{T}_{\mathrm{x}}{ }^{389} \mathrm{~S}^{388}\end{array}$} \\
\hline & $65-75_{2.0}^{388}$ & $63-77_{2.6}^{381}$ & $15-80_{7.0}^{389}$ & \\
\hline $\mathrm{Bi}-\mathrm{Ba}$ & $\mathrm{X}_{2.6}^{244}$ & $\mathrm{X}_{1,0 ; 2.0}{ }^{270}$ & $70-98_{3.5}^{270}$ & $\mathrm{P}^{270} \mathrm{~V}^{244,270^{\circ}}$ \\
\hline $\mathrm{Bi}-\mathrm{Pb}$ & $\mathrm{X}_{2.6}^{244}$ & $18-89_{3.5^{108}}$ & $40-85_{4.5^{115}}$ & $\mathrm{~V}^{108,115,244} \mathrm{~T}_{\mathrm{g}}+\mathrm{T}_{\mathrm{x}}{ }^{108} \mathrm{~W}+\mathrm{R}^{384} \dagger$ \\
\hline $\mathrm{Bi}-\mathrm{Cu}(\mathrm{Pb}-\mathrm{Cu})$ & $43-82_{4.5} 390$ & $46-95_{3.5}^{108}$ & $\left(30-90_{3.5}{ }^{108}\right)$ & $\mathrm{V}+\mathrm{T}_{\mathrm{x}}{ }^{108,390} \mathrm{~T}_{\mathrm{s}}{ }^{108} \mathrm{~S}+\mathrm{T}_{\mathrm{g}}+\rho+\mathrm{W}+\mathrm{p}^{390}$ \\
\hline Bi-Mn & $67-95_{3.5}^{108}$ & & & $\mathrm{~V}+\mathrm{T}_{\mathrm{s}}+\mathrm{T}_{\mathrm{x}}{ }^{108}$ \\
\hline $\mathrm{Bi}-\mathrm{Fe}$ & $69-94_{3.2}^{391}$ & & & $\mathrm{~V}+\mathrm{T}_{\mathrm{g}}+\rho+\sigma+\varepsilon^{391}$ \\
\hline $\mathrm{Bi}-\mathrm{Ti}$ & $75-89_{3.5}^{108}$ & & & $\mathrm{~V}+\mathrm{T}_{\mathrm{s}}+\mathrm{T}_{\mathrm{x}}{ }^{108}$ \\
\hline $\mathrm{Bi}-\mathrm{Ga}$ & $57-80_{2.6}{ }^{106}$ & & & $\mathrm{~V}^{106} \mathrm{~S}$ (neutron \& XRD \& $\left.\mathrm{Pb}-\mathrm{Ga}\right)^{109}$ \\
\hline
\end{tabular}

*Vitrification range; $\mathrm{X}=$ none found.

$\uparrow$ Probable $\mathrm{Al}_{2} \mathrm{O}_{3}$ contamination from crucible.

\section{Binary systems}

The binary $\mathrm{Bi}_{2} \mathrm{O}_{3}-\mathrm{B}_{2} \mathrm{O}_{3}$ system has been studied most extensively, and vitrifies easily at low cooling rates. ${ }^{318} \mathrm{~A}$ minimal amount of $\mathrm{Bi}_{2} \mathrm{O}_{3}$ is seen to be necessary due to the miscibility gap in the phase diagram ${ }^{110}$ (which also exists with $\mathrm{PbO}-\mathrm{Bi}_{2} \mathrm{O}_{3}{ }^{136}$ and many other borates), setting a practical limitation for technical purposes to above ca. $19 \% \mathrm{Bi}_{2} \mathrm{O}_{3}$, the end of the gap. It is nevertheless possible to achieve apparently homogeneous vitrification throughout this range if quenching sufficiently fast from above the gap. ${ }^{110}$

For the "strict" $\mathrm{Bi}_{2} \mathrm{O}_{3}-\mathrm{B}_{2} \mathrm{O}_{3}$ binary, the extensive and well-controlled work of Becker ${ }^{318}$ (very large melts, controlled cooling, noble metal crucibles, 20-43\% $\mathrm{Bi}_{2} \mathrm{O}_{3}$ ) is deemed the most reliable for slow cooling. At intermediate cooling rates, the maximum $\mathrm{Bi}$ content is around $60 \%,{ }^{118,244,317}$ with $66 \%$ achievable for splat quenching. ${ }^{317}$ Going to twin roller quenching increases the vitrification range further, to $0-88 \% \mathrm{Bi}^{110,248}$

The $\mathrm{Bi}_{2} \mathrm{O}_{3}$-rich ends of the glass-forming ranges with $\mathrm{B}_{2} \mathrm{O}_{3}$ and $\mathrm{SiO}_{2}$ are often reported to be quite different from each other, and also from the values for PbO. However, as noticed by Dumbaugh and Lapp, ${ }^{36}$ this is due to the arbitrary selection of the "molecules" $\mathrm{PbO}, \mathrm{Bi}_{2} \mathrm{O}_{3}$, $\mathrm{B}_{2} \mathrm{O}_{3}$ and $\mathrm{SiO}_{2}$; on a cation basis, these limits ( $\mathrm{Pb}$ vs. $\mathrm{Bi}$ and $\mathrm{B}$ vs. $\mathrm{Si}$ ) become more similar, as illustrated by the results of fast quenching experiments by Stehle, George et al., 110,248 where the four systems were examined in the same conditions; for $\mathrm{Bi}_{2} \mathrm{O}_{3}-\mathrm{SiO}_{2}$, a maximum of ca. $85 \% \mathrm{Bi}$ is obtained.

To summarise the data on binary systems with the common glass formers $\left(\mathrm{B}_{2} \mathrm{O}_{3}, \mathrm{SiO}_{2}, \mathrm{P}_{2} \mathrm{O}_{5}\right.$, $\mathrm{GeO}_{2}$ ), the vitrification ranges (in cation\%) of $\mathrm{Bi}_{2} \mathrm{O}_{3}$ and $\mathrm{PbO}$ appear similar, although a direct comparison is difficult due to the spread in experimental data and the paucity of experiments under the same conditions. The maximum $\mathrm{Bi}_{2} \mathrm{O}_{3}$ content is smaller with $\mathrm{GeO}_{2}$, and even more with $\mathrm{P}_{2} \mathrm{O}_{5}$; the $\mathrm{Bi}_{2} \mathrm{O}_{3}-\mathrm{P}_{2} \mathrm{O}_{5}$ system has therefore attracted limited attention. The reverse is seen for $\mathrm{SnO}$, where vitrification is especially favourable with $\mathrm{P}_{2} \mathrm{O}_{5}$, resulting in glasses based on the $\mathrm{SnO}-\mathrm{P}_{2} \mathrm{O}_{5}$ system being another promising substitute to lead-based ones (see section 2.3).

With the unconventional network formers, vitrification is more difficult in general, and more severe quenching must be applied; comparing with $\mathrm{PbO}$, vitrification appears to be more difficult for $\mathrm{Bi}_{2} \mathrm{O}_{3}$ with $\mathrm{TeO}_{2}$ and $\mathrm{V}_{2} \mathrm{O}_{5}$, while the reverse is true with $\mathrm{MoO}_{3}$. Under fast to very fast quenching, binary glasses may be obtained with $\mathrm{Li}_{2} \mathrm{O}, \mathrm{BaO}, \mathrm{PbO}, \mathrm{CuO}_{y}, \mathrm{MnO}_{y}$ and $\mathrm{Ga}_{2} \mathrm{O}_{3}$. 


\section{Complex systems with traditional network formers}

As mentioned earlier, even small amounts of $\mathrm{Al}_{2} \mathrm{O}_{3}$ and especially $\mathrm{SiO}_{2}$ leached from the crucible considerably facilitate vitrification in the $\mathrm{Bi}_{2} \mathrm{O}_{3}-\mathrm{B}_{2} \mathrm{O}_{3}$ system. This synergistic vitrification is confirmed by experiments with $\mathrm{B} \approx \mathrm{Si}$, where $74 \% \mathrm{Bi}$ may be achieved by conventional melting and casting, ${ }^{361}$ i.e. much more than in either the $\mathrm{Bi}_{2} \mathrm{O}_{3}-\mathrm{B}_{2} \mathrm{O}_{3}$ or $\mathrm{Bi}_{2} \mathrm{O}_{3}$ $\mathrm{SiO}_{2}$ binary system. This is also true for low $\mathrm{SiO}_{2} \& \mathrm{Al}_{2} \mathrm{O}_{3}$ additions: a $65 \mathrm{BiO}_{1.5}+33 \mathrm{BO}_{1.5}$ $+2 \mathrm{SiO}_{2}$ composition vitrifies easily when casting large plates, ${ }^{112}$ as does $70 \mathrm{BiO}_{1.5}+25 \mathrm{BO}_{1.5}$ $+3 \mathrm{SiO}_{2}+3 \mathrm{AlO}_{1.5}$ under moderate quenching. ${ }^{324}$ Such modifications are therefore very useful for low-melting glasses rich in $\mathrm{Bi}_{2} \mathrm{O}_{3}$, as they stabilise the glass with only limited impact on processing temperature. ${ }^{314}$

Synergistic vitrification also occurs, for a given network former, when replacing on a cation basis part of the $\mathrm{Bi}_{2} \mathrm{O}_{3}$ with other alkaline earth and transition metal oxides. This occurs in spite of a generally poorer vitrification with these oxides (except $\mathrm{PbO}$ ) taken individually than with $\mathrm{Bi}_{2} \mathrm{O}_{3}$, and is seen for borates with $\mathrm{SrO},{ }^{246,258,}{ }^{346} \mathrm{BaO},{ }^{246,258,270,349} \mathrm{PbO},{ }^{130,}$ 246, 279 $\mathrm{ZnO}^{246,354,355,392}$ and $\mathrm{CuO}_{y}{ }^{249}$ Figure 4, redrawn on a cation basis from the original studies, ${ }^{249,} 354$ illustrates the case of the $\mathrm{Bi}_{2} \mathrm{O}_{3}-\mathrm{B}_{2} \mathrm{O}_{3}$ binary extended with $\mathrm{ZnO}$ and $\mathrm{CuO}_{y}$ : there is clearly an optimum in substitution that minimises the required amount of network former. This composition "hump" roughly agrees with low-melting zones in the corresponding ternary equilibrium diagrams. ${ }^{354,356}$ In commercial low-melting glasses based on $\mathrm{ZnO}-\mathrm{Bi}_{2} \mathrm{O}_{3}-\mathrm{B}_{2} \mathrm{O}_{3}$ (Table 7, Hg-Nch-Usu), the $\mathrm{Zn}$ :Bi ratio - in practice also influenced by other considerations such as acid resistance - is commonly $0.2 \ldots 0.7$. In most cases, $\mathrm{Zn}$ is preferred over $\mathrm{Cu}$ due to the easy occurrence of mixed valence in the latter, leading to semiconductivity in $\mathrm{Cu}$-rich glasses ${ }^{249}$ - a drawback mainly for insulators. This said, excluding $\mathrm{PbO}$ and alkalis, $\mathrm{Zn}$ and $\mathrm{Cu}$ apparently give the lowest melting points in the ternary phase diagrams, with the deepest eutectics somewhat below $600^{\circ} \mathrm{C}$; the $\mathrm{BaO}-\mathrm{Bi}_{2} \mathrm{O}_{3}-\mathrm{B}_{2} \mathrm{O}_{3}$ system, for instance, ${ }^{347,348}$ apparently is fully solid at $600^{\circ} \mathrm{C}$. Going one step further in complexity, mixing both network formers and modifier, allows a further decrease in the required amount of the former, as seen for $\mathrm{PbO}-\mathrm{ZnO}-\mathrm{Bi}_{2} \mathrm{O}_{3}-\mathrm{B}_{2} \mathrm{O}_{3}-\mathrm{SiO}_{2}$ glasses, ${ }^{256}$ in line with the general trend towards more difficult crystallisation of multicomponent glasses.

In contrast to these oxides, an extension of the glass-forming range to lower $\mathrm{B}_{2} \mathrm{O}_{3}$ contents is not seen with the light alkali elements $\mathrm{Li}, \mathrm{Na}$ and $\mathrm{K}$ (Figure 5 ) ${ }^{247}$ the effect for small substitutions of $\mathrm{BiO}_{1.5}$ by alkalis is neutral up to ca. $25 \% \mathrm{LiO}_{0.5}$, then the minimum $\mathrm{B}_{2} \mathrm{O}_{3}$ required for vitrification rises sharply; this threshold is much lower (ca. 3\%) for $\mathrm{NaO}_{0.5}$ and practically zero for $\mathrm{KO}_{0.5}$. Under fast cooling in the more complex $\mathrm{R}_{2} \mathrm{O}-\mathrm{ZnO}-\mathrm{Bi}_{2} \mathrm{O}_{3}-$ $\mathrm{B}_{2} \mathrm{O}_{3}(\mathrm{R}=\mathrm{Li}, \mathrm{Na}, \mathrm{K})$ system, a deleterious effect on vitrification was also observed, with a similar, but less pronounced trend of the size of the vitrification domain $(\mathrm{Li}>\mathrm{Na}>\mathrm{K}) .{ }^{392}$ Qualitatively, this agrees with the relatively stringent limits set on alkali content in the patents of Hasegawa et al., ${ }^{313,314}$ as discussed in section 4.1.

While small amounts of rare-earth additions are common for luminescence studies, the effect of larger quantities on vitrification $\mathrm{Bi}_{2} \mathrm{O}_{3}-\mathrm{B}_{2} \mathrm{O}_{3}$ have been less studied; especially, experiments where $\mathrm{Bi}_{2} \mathrm{O}_{3}$ is systematically replaced by $\mathrm{Ln}_{2} \mathrm{O}_{3}(\mathrm{Ln}=$ rare earth and $\mathrm{Y}$, except Ce) are lacking. Experiments by Pascuta et al., ${ }^{276-278,357}$ while extensive, were carried out on relatively unstable glasses with a low amount of $\mathrm{B}_{2} \mathrm{O}_{3}\left(20 \ldots 33 \% \mathrm{BO}_{1.5}\right)$, requiring fast quenching; they could replace ca. $25 \%$ to $35 \%$ of the whole glass, on a cation basis, by $\mathrm{GdO}_{1.5}$ or $\mathrm{EuO}_{1.5}$ (they achieving similar results with $\mathrm{GeO}_{2}$ as a network former ${ }^{374}$ ). Stabilisation of the glass was also observed with $5 \% \mathrm{Fe}_{2} \mathrm{O}_{3}{ }^{255}$. Compositions reported by this group for this and other systems $255,274,276-278,357,374,384,393,394$ must be taken with caution, however, as they used very high melting temperatures $\left(1100^{\circ} \mathrm{C}\right.$ and above) in $\mathrm{Al}_{2} \mathrm{O}_{3}$ crucibles and their 
reported glass-forming ranges - $>90 \% \mathrm{BiO}_{1.5}$ for moderate quenching! - seem too high (see Table 12); their compositions are therefore likely to be shifted by reaction or volatilisation.

For more stable glasses $\left(\mathrm{Bi}_{2} \mathrm{O}_{3} \cdot 2 \mathrm{~B}_{2} \mathrm{O}_{3}\right)$, vitrification is easy and therefore not affected by small $\mathrm{Ln}_{2} \mathrm{O}_{3}$ additions; however, strong suppression of crystallisation upon reheating was observed for $5 \% \mathrm{La}_{2} \mathrm{O}_{3}$ and $3 \% \mathrm{Er}_{2} \mathrm{O}_{3} .{ }^{275}$ In the patent literature (complex glasses based on $\mathrm{ZnO}-\mathrm{Bi}_{2} \mathrm{O}_{3}-\mathrm{B}_{2} \mathrm{O}_{3}$ ), maximal rare earth content is reported to be at ca. 4 to $8 \%$, lower-melting glasses being more sensitive. ${ }^{314}$

For the less-studied silicates and germanates, a wide maximum in synergistic vitrification range is achieved when mixing $\mathrm{Bi}_{2} \mathrm{O}_{3}$ with $\mathrm{PbO}^{129,367,369}$ or $\mathrm{PbO} \&$ some $\mathrm{BaO}^{107}$ and, while systematic studies are lacking, successful incorporation of large amounts of alkaline earth / transition metal oxides with low network former content is reported; ${ }^{246,250,251}$ for instance Janakirama-Rao reports facile vitrification of $31 \mathrm{RO}+62 \mathrm{BiO}_{1.5}+7 \mathrm{SiO}_{2}$, where $\mathrm{R}=\mathrm{Sr}, \mathrm{Ba}$, $\mathrm{Pb}$ or $\mathrm{Zn}$, i.e with a much lower amount of $\mathrm{SiO}_{2}$ than needed for vitrification in the binary systems, and similar results when adding two oxides $\left(\mathrm{CdO} \& \mathrm{WO}_{3}, \mathrm{PbO} \& \mathrm{MnO}_{y}, \mathrm{PbO}\right.$ $\& \mathrm{CuO}_{y}$ ) to the $\mathrm{Bi}_{2} \mathrm{O}_{3}-\mathrm{SiO}_{2}$ binary. ${ }^{246}$ In comparison, the $\mathrm{PbO}-\mathrm{SiO}_{2}$ system is also quite tolerant for substitution of $\mathrm{PbO}$ by $\mathrm{NiO}, \mathrm{ZnO}, \mathrm{MnO}_{y}$ and $\mathrm{FeO}_{y}{ }^{395}$ - though a decrease of required $\mathrm{SiO}_{2}$ is not observed for small substitutions, in contrast to the $\mathrm{Bi}_{2} \mathrm{O}_{3}-\mathrm{B}_{2} \mathrm{O}_{3}$ system.

Data on alkali additions is not as complete as with borates. At $<10 \%$ (cation) $\mathrm{Si}, \mathrm{R}_{2} \mathrm{O}-\mathrm{Bi}_{2} \mathrm{O}_{3}-$ $\mathrm{SiO}_{2}$ is reported not to vitrify for $\mathrm{R}=\mathrm{Li}, \mathrm{Na}$ or $\mathrm{K}$ (as with borates), but to vitrify easily with $\mathrm{R}=\mathrm{Rb}$ or $\mathrm{Cs}$, even with a very large $(>50 \%)$ degree of substitution of Bi by $\mathrm{R}^{246}$

Extensions of the glass-forming range by other oxides also occur with vanadates $\left(\mathrm{Fe}_{2} \mathrm{O}_{3}{ }^{234}\right)$, molybdates $\left(\mathrm{PbO}^{115}, \mathrm{Fe}_{2} \mathrm{O}_{3}{ }^{234}\right)$ and even gallates $\left(\mathrm{PbO} \& \mathrm{CdO}^{36}\right)$. In the case of phosphates, vitrification with $\mathrm{ZnO}$ occurs over a wider range than with $\mathrm{Bi}_{2} \mathrm{O}_{3}$, but a synergistic effect is achieved nonetheless, albeit in this case with less $\mathrm{Bi}_{2} \mathrm{O}_{3}$ than $\mathrm{ZnO}^{262}$

\section{Glasses without network formers}

Besides providing new insights in glass formation, glasses without traditional network formers are of interest for optical applications (section 5.1), provided other light-element oxides with strong oxygen bonding (especially $\mathrm{Al}_{2} \mathrm{O}_{3}$ ) are absent.

Although early attempts to make glasses of $\mathrm{Bi}_{2} \mathrm{O}_{3}$ without at least a very small amount of true network formers were unsuccessful, ${ }^{244,246}$ several such binary systems were later successfully vitrified under twin roller quenching (Table 11), and melts with $\mathrm{Li}_{2} \mathrm{O}$ and $\mathrm{Ga}_{2} \mathrm{O}_{3}$ were observed to actually vitrify under relatively moderate quenching.

Adding more components facilitates glass formation, of which several examples are given in Table 13. Extension of the $\mathrm{Li}_{2} \mathrm{O}$ compositions to systems such as $\mathrm{Li}_{2} \mathrm{O}-\mathrm{BaO} / \mathrm{PbO}-\mathrm{Bi}_{2} \mathrm{O}_{3}$ significantly facilitates vitrification. ${ }^{381,382}$ Khalilov $^{107}$ systematically modified glasses based on $\mathrm{Bi}_{2} \mathrm{O}_{3}-\mathrm{SiO}_{2}$ with binary or more complex combinations of $\mathrm{PbO}, \mathrm{BaO}, \mathrm{CdO}, \mathrm{ZnO}$, and $\mathrm{MgO}$, under moderate quenching (cast in metallic moulds and covered with plates), and $\mathrm{SiO}_{2}-$ free $\mathrm{Bi}_{2} \mathrm{O}_{3}-\mathrm{PbO}-\mathrm{BaO}-\mathrm{CdO}-\mathrm{ZnO}$ (+optional $\mathrm{MgO}$ ) glasses were obtained; as the mixtures were melted in Pt crucibles, contamination by $\mathrm{SiO}_{2}, \mathrm{Al}_{2} \mathrm{O}_{3}$ or $\mathrm{B}_{2} \mathrm{O}_{3}$ can safely be excluded. Other similar systems are $\mathrm{SrO}-\mathrm{PbO}-\mathrm{Bi}_{2} \mathrm{O}_{3}{ }^{117}$ and $\mathrm{CaO}-\mathrm{SrO}-\mathrm{PbO}-\mathrm{Bi}_{2} \mathrm{O}_{3}-\mathrm{CuO}_{y}{ }^{99}$ (useful for processing superconductors via the glass-ceramic route - see section 5.3), and $\mathrm{PbO}-\mathrm{CdO}-$ $\mathrm{Bi}_{2} \mathrm{O}_{3}-\mathrm{Fe}_{2} \mathrm{O}_{3} .{ }^{36} \mathrm{Ga}_{2} \mathrm{O}_{3}$ was found to be particularly useful to promote glass formation, with the relatively simple $\mathrm{PbO}-\mathrm{Bi}_{2} \mathrm{O}_{3}-\mathrm{Ga}_{2} \mathrm{O}_{3}$ system exhibiting easy vitrification over a wide composition range and even allowing casting of large objects. ${ }^{36,106,386}$ 
Table 12. Glass-forming range* of $\mathrm{Bi}_{2} \mathrm{O}_{3}$ and $\mathrm{PbO} / \mathrm{SnO} \uparrow$ binary systems with networkforming oxides, with quenching index $Q$ and crucible + indicated as subscript.

\begin{tabular}{|c|c|c|c|c|c|c|c|}
\hline \multirow{7}{*}{$\begin{array}{l}\text { Network former } \\
\mathrm{B}_{2} \mathrm{O}_{3} \\
\left(\text { as } \mathrm{BO}_{1.5}\right)\end{array}$} & \multirow{2}{*}{$\frac{\text { Limit }}{\text { Min }}$} & \multicolumn{4}{|c|}{$\mathrm{Bi}_{2} \mathrm{O}_{3}\left(\operatorname{as~} \mathrm{BiO}_{1.5}\right)^{*}$} & \multicolumn{2}{|c|}{$\mathrm{PbO}^{*}(\mathrm{SnO}) \dagger$} \\
\hline & & $25_{1.5 \S^{246}}{ }^{215}$ & $\begin{array}{l}22_{1.2 \mathrm{P}}{ }^{247} \\
19_{1.270}{ }^{270}\end{array}$ & $\begin{array}{l}22_{1.0}^{245} \\
19_{3.55^{270}}\end{array}$ & $20_{-1.8 \mathrm{~N}^{110}}{ }^{318}$ & $11_{1.0}^{245}$ & $11_{2.0}{ }^{246}$ \\
\hline & Max & $43_{-1.8 \mathrm{~N}} 318$ & $57_{1.2 \mathrm{~A}} 315$ & $57_{2.6 \mathrm{~N}} 244$ & $\begin{array}{c}5.2 \mathrm{~N} \\
60_{2.0 \mathrm{~N}} 317\end{array}$ & $60_{0.6^{129}}$ & $62_{1.0}^{245}$ \\
\hline & & $60_{2.6}^{325}$ & $65_{1.0}^{245}$ & $66_{3.0 \mathrm{~N}}^{317}$ & $67_{1.5 \#}^{246}$ & $67_{2.6 \mathrm{~N}}{ }^{397}$ & $80_{1.5}{ }^{246}$ \\
\hline & & $68_{1.2 P^{247}}^{247}$ & $70_{1.6 \mathrm{P}}{ }^{324}$ & $70_{2.6 \mathrm{~s}} \mathrm{~S}^{396}$ & $70_{1.0 \mathrm{~S}}{ }^{270}$ & $89_{5.2 \mathrm{~N}}^{248}$ & \\
\hline & & $75_{2.0 \mathrm{~A}}{ }^{357}$ & $75_{2.0 \mathrm{~A}}{ }^{274}$ & $75_{1.2 \mathrm{P}}{ }^{254}$ & $80_{1.2 \mathrm{P}}{ }^{132}$ & & \\
\hline & & $80_{1.6 \mathrm{~A}}{ }^{332}$ & $80_{2.0 \mathrm{~S}}{ }^{270}$ & $88_{5.2 \mathrm{~N}}{ }^{110}$ & $96_{3.5 \mathrm{~s}}{ }^{270}$ & $60_{2.5 \mathrm{Sn}}^{398}$ & \\
\hline \multirow[t]{3}{*}{$\mathrm{SiO}_{2}$} & Min & & & & & $0^{136}$ & \\
\hline & Max & $51_{0.6}{ }^{129}$ & $57_{2.6}^{244}$ & $63_{1.0}^{245}$ & $61_{1.6}^{118}$ & $60_{0.6^{129}}$ & $65_{1.3 \mathrm{~N}^{395}}$ \\
\hline & & $67_{1.8}^{107}$ & $85_{5.2 \mathrm{~N}} 248$ & $95_{1.2 \mathrm{P}} 131$ & & $67_{1.0}^{245}$ & $82_{5.2 \mathrm{~N}^{248}}^{248}$ \\
\hline \multirow[t]{3}{*}{$\mathrm{GeO}_{2}$} & Min & $0_{5.4}^{231}$ & $30_{0.0 \mathrm{~N}}{ }^{369}$ & & & $0_{0.0 \mathrm{~N}}^{369}$ & \\
\hline & Max & $43_{0.0 \mathrm{~N}}^{369}$ & $51_{1.0}^{245}$ & $55_{2.6 \mathrm{~N}}{ }^{369}$ & $57_{3.4}{ }^{372}$ & $46_{0.0 \mathrm{~N}}^{369}$ & $57_{1.0}^{245}$ \\
\hline & & $70_{5.4}^{231}$ & $80_{1.6 \mathrm{~A}}{ }^{374}$ & $89_{2.0 \mathrm{~A}}{ }^{374}$ & $92_{4.2}{ }^{368}$ & $67_{2.6 \mathrm{~N}}{ }^{369}$ & \\
\hline \multirow{2}{*}{$\begin{array}{l}\mathrm{P}_{2} \mathrm{O}_{5} \\
\left(\text { as } \mathrm{PO}_{2.5}\right)\end{array}$} & Min & $\approx 0_{0.6}{ }^{376}$ & & & & $0_{1.0^{245}}$ & \\
\hline & Max & $40_{0.6}{ }^{376}$ & $40_{2.6}{ }^{244}$ & $45_{1.2}{ }^{375}$ & & $45_{1.0}^{245}$ & $58_{1.6 \mathrm{Sn}}{ }^{182}$ \\
\hline \multirow[t]{2}{*}{$\mathrm{TeO}_{2}$} & Min & $\mathrm{X}_{1.0}{ }^{245}$ & $0_{2.6}^{244}$ & & & $11_{1.0}^{245}$ & \\
\hline & Max & $\mathrm{X}_{1.0}^{245}$ & $19_{2.6}{ }^{244}$ & & & $22_{1.0}^{245}$ & \\
\hline \multirow{2}{*}{$\begin{array}{l}\mathrm{V}_{2} \mathrm{O}_{5} \\
\left(\text { as } \mathrm{VO}_{2.5}\right)\end{array}$} & Min & $0_{2.6}{ }^{244}$ & $0_{4.0}^{238}$ & $0_{5.4}{ }^{231}$ & & $0_{4.0}{ }^{238}$ & \\
\hline & Max & $18_{2.6}^{244}$ & $29_{4.0}^{238}$ & $40_{5.4}{ }^{231}$ & & $43_{4.0}^{238}$ & \\
\hline \multirow[t]{2}{*}{$\mathrm{MoO}_{3}$} & Min & $28_{4.5}{ }^{115}$ & & & & $\mathrm{X}_{4.5}^{115}$ & \\
\hline & Max & $53_{4.5}^{115}$ & & & & $\mathrm{X}_{4.5}^{115}$ & \\
\hline
\end{tabular}

*Limits given as cation $\%$ of $\mathrm{Bi}, \mathrm{Pb}$ or $\mathrm{Sn}$. $\mathrm{X}$ : no glass-forming domain found.

$\dagger$ Values for $\mathrm{SnO}$ systems (more data in review ${ }^{219}$ ) given in same column as $\mathrm{PbO}$, in italic and with ' $\mathrm{Sn}$ ' suffix. $\$$ Crucible types: $\mathrm{S}$ : $\mathrm{SiO}_{2}$ crucible; $\mathrm{A}: \mathrm{Al}_{2} \mathrm{O}_{3}$; P: porcelain or similar; N: noble metal.

\# Assumed $\mathrm{Bi}_{2} \mathrm{O}_{3}$ is in fact represented as $\mathrm{BiO}_{1.5}$ in the diagrams.

Table 13. Glasses without standard network formers: complex systems

\begin{tabular}{|c|c|c|c|c|c|c|c|c|}
\hline \multicolumn{2}{|c|}{ System (oxide cations) } & \multicolumn{6}{|c|}{ Composition (typ., cation\%) } & \multirow{2}{*}{$\frac{Q}{2.6}$} \\
\hline $\mathrm{Li}-\mathrm{Ba}-\mathrm{Bi}^{381}$ & $\mathrm{Fu}-1$ & $22 \mathrm{Li}$ & $+12 \mathrm{Ba}$ & $+67 \mathrm{Bi}$ & & & & \\
\hline $\mathrm{Sr}-\mathrm{Pb}-\mathrm{Bi}^{117}$ & & $14 \mathrm{Sr}$ & $+29 \mathrm{~Pb}$ & $+57 \mathrm{Bi}$ & & & & 2.0 \\
\hline $\mathrm{Pb}-\mathrm{Cd}-\mathrm{Bi}-\mathrm{Fe}$ & Dmb-H & $40 \mathrm{~Pb}$ & $+15 \mathrm{Cd}$ & $+20 \mathrm{Bi}$ & $+25 \mathrm{Fe}$ & & & 1.2 \\
\hline $\mathrm{Zn}-\mathrm{Bi}-\mathrm{Fe}^{316}$ & & $11 \mathrm{Zn}$ & $+40 \mathrm{Bi}$ & $+49 \mathrm{Fe}$ & & & & 4.2 \\
\hline \multirow{2}{*}{$\begin{array}{l}\mathrm{Pb}-\mathrm{Zn}-\mathrm{Cd}-\mathrm{Bi}-\mathrm{Ba} \\
\text { Idem }+\mathrm{Mg}^{107}\end{array}$} & Khv-12 & $5 \mathrm{Ba}$ & $+14 \mathrm{~Pb}$ & $+8 \mathrm{Zn}$ & $+9 \mathrm{Cd}$ & $+64 \mathrm{Bi}$ & & 1.8 \\
\hline & Khv-13 & $4 \mathrm{Ba}$ & $+14 \mathrm{~Pb}$ & $+7 \mathrm{Zn}$ & $+8 \mathrm{Cd}$ & $+64 \mathrm{Bi}$ & $+3 \mathrm{Mg}$ & 1.8 \\
\hline \multirow{3}{*}{$\begin{array}{l}\mathrm{Pb}-\mathrm{Bi}-\mathrm{Ga}^{36} \\
\mathrm{~Pb}-\mathrm{Bi}-\mathrm{Ga}^{128}\end{array}$} & Dmb-EO & $40 \mathrm{~Pb}$ & $+35 \mathrm{Bi}$ & $+25 \mathrm{Ga}$ & & & & 1.2 \\
\hline & $\mathrm{McC}-1$ & $31 \mathrm{~Pb}$ & $+39 \mathrm{Bi}$ & $+30 \mathrm{Ga}$ & & & & 1.6 \\
\hline & $\mathrm{McC}-2$ & $23 \mathrm{~Pb}$ & $+59 \mathrm{Bi}$ & $+18 \mathrm{Ga}$ & & & & 1.6 \\
\hline $\mathrm{Cd}-\mathrm{Bi}-\mathrm{Ga}^{36}$ & Dmb-IV & $15 \mathrm{Cd}$ & $+70 \mathrm{Bi}$ & $+15 \mathrm{Ga}$ & & & & 1.2 \\
\hline $\mathrm{Ba}-\mathrm{Zn}-\mathrm{Bi}-\mathrm{Ga}^{36}$ & Dmb-D & $10 \mathrm{Ba}$ & $+10 \mathrm{Zn}$ & $+24 \mathrm{~Pb}$ & $+56 \mathrm{Bi}$ & & & 1.2 \\
\hline $\mathrm{Ca}-\mathrm{Sr}-\mathrm{Pb}-\mathrm{Bi}-\mathrm{Cu}^{99}$ & HTS-1 & $22 \mathrm{Ca}$ & $+22 \mathrm{Sr}$ & $-5 \mathrm{~Pb}$ & $+33 \mathrm{Cu}$ & $+18 \mathrm{Bi}$ & & 2.9 \\
\hline
\end{tabular}




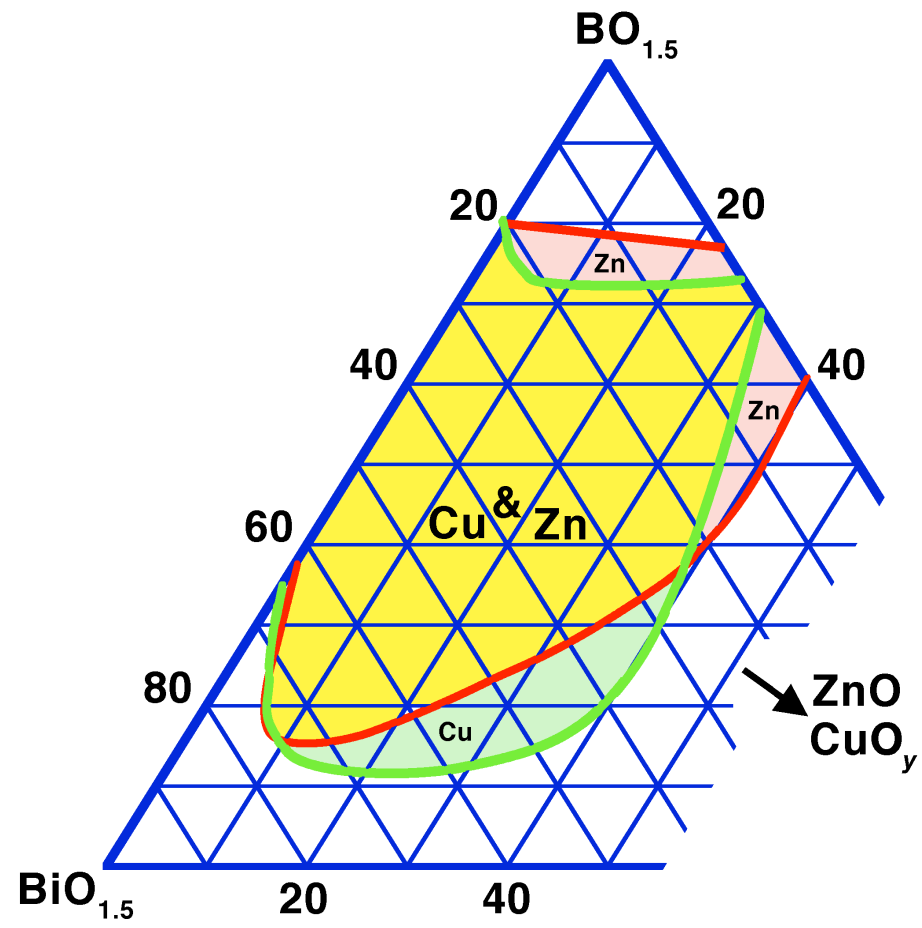

Figure 4. Vitrification range in the $\mathrm{Bi}_{2} \mathrm{O}_{3}-\mathrm{B}_{2} \mathrm{O}_{3}-\mathrm{ZnO}^{354} / \mathrm{CuO}_{y}{ }^{249}$ systems (cation basis).

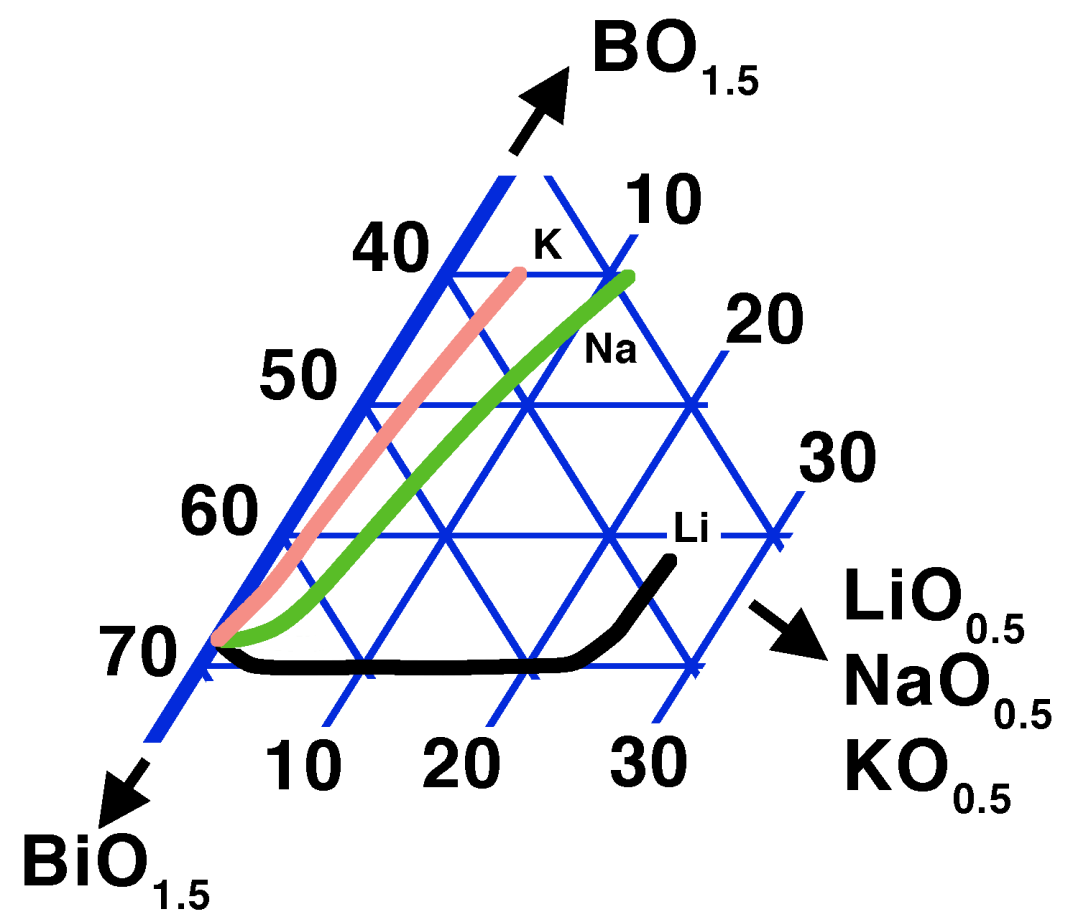

Figure 5. Effect of $\mathrm{R}_{2} \mathrm{O}$ on min. $\mathrm{B}_{2} \mathrm{O}_{3}$ in the $\mathrm{R}_{2} \mathrm{O}-\mathrm{Bi}_{2} \mathrm{O}_{3}-\mathrm{B}_{2} \mathrm{O}_{3}(\mathrm{R}=\mathrm{Li}, \mathrm{Na}, \mathrm{K})$ systems. ${ }^{247}$ 


\section{Conclusions}

The following remarks may be derived from the data on glass formation:

- $\mathrm{Bi}^{3+}$, akin to $\mathrm{Pb}^{2+}$, is a large, polarisable ion; both, while not vitrifying alone, behave as conditional network formers, requiring "abnormally" low amounts of true network formers for successful vitrification at moderate cooling rates.

- The $\mathrm{Bi}_{2} \mathrm{O}_{3}-\mathrm{B}_{2} \mathrm{O}_{3}$ system appears to be the most promising basis for the fabrication of stable lead-free $\mathrm{Bi}_{2} \mathrm{O}_{3}$ glasses with low processing temperatures, but does not allow by itself processing temperatures as low as those of the corresponding $\mathrm{PbO}-\mathrm{B}_{2} \mathrm{O}_{3}$ system.

- In the $\mathrm{Bi}_{2} \mathrm{O}_{3}-\mathrm{B}_{2} \mathrm{O}_{3}$ system, adding low amounts of $\mathrm{SiO}_{2}$ and other oxides such as $\mathrm{ZnO}$, $\mathrm{Al}_{2} \mathrm{O}_{3}$, and $\mathrm{Fe}_{2} \mathrm{O}_{3}$ also stabilises the glass without largely increasing processing temperatures. Further studies, however, are needed to better define glass stability as a function of composition, especially upon re-heating, which is critical for TF processes (see section 4.1 for some information in this regard).

- Mixing several oxides of large, polarisable cations, such as $\mathrm{Bi}_{2} \mathrm{O}_{3}, \mathrm{PbO}$ and $\mathrm{BaO}$ tends to stabilise the glasses and/or lower the required amount of true network formers; adding limited amounts of other transition metal or rare earth oxides furthers this trend.

- Using rapid cooling, glasses containing $\mathrm{Bi}_{2} \mathrm{O}_{3}$ and $\mathrm{PbO}$ may be formed in the complete absence of true network formers. The $\mathrm{PbO}-\mathrm{Bi}_{2} \mathrm{O}_{3}-\mathrm{Ga}_{2} \mathrm{O}_{3}$ system provides an especially favourable base for such HMO glasses.

\subsection{Glass structure}

\section{General considerations}

Since the "anomalous" ease of vitrification of $\mathrm{Bi}_{2} \mathrm{O}_{3}$ with standard network formers, similar to that of $\mathrm{PbO}$, was noticed in early work, ${ }^{244-246}$ numerous studies have been devoted to elucidating the structure of $\mathrm{Bi}_{2} \mathrm{O}_{3}$-based glasses, using methods such as X-ray diffraction (XRD), Fourier-transform infrared (FTIR), Raman, electron paramagnetic/spin resonance (EPR/ESR), Mössbauer, X-ray absorption (XAS / EXAFS) and magic-angle-spinning nuclear magnetic resonance (MAS-NMR) spectroscopy. A good knowledge of structural features is required to efficiently correlate glass properties with chemical data; ${ }^{327,329,399-401}$ this is especially important for borate glasses, given the different possible forms and structures assumed by borate anions. ${ }^{402}$

\section{Bonding in crystalline compounds}

To provide additional insight into the structural features of $\mathrm{Bi}_{2} \mathrm{O}_{3}$-based glasses, a survey of a range of relevant and related crystalline oxides, where atomic positions may be precisely determined, was carried out (supplement, section 13). Even in crystalline oxides, $\mathrm{Bi}^{3+}$ adopts a wide variety of asymmetric, disordered and often ill-defined coordination polyhedra, presumably due to its high polarisability ${ }^{400}$ and stereochemically active "lone pair" electrons, and bonding with oxygen is fairly covalent. An overview of idealised typical oxygen coordination shells observed around $\mathrm{Bi}^{3+}$ cations, in the crystalline oxides examined in the supplement, is given in Figure 6, with the corresponding descriptions in Table 14. The lone pair may strongly deform the oxygen coordination shell (6-Oct33), and often replaces an oxygen anion to "fill" the corresponding vacancy (3-PyM, 4-BPy / 4-PyM, 5-Py14). Recently, the lone-pair concept has been revisited in the light of diffraction data and spectroscopic studies of band structure, coupled with detailed computational modelling ${ }^{403}$ (see other 
references in supplement 13); the lone pair is found to stem from interaction of both metal valence $s$ and $p$ orbitals, mediated by oxygen $2 p$ ones.

In compounds, $\mathrm{Bi}^{3+}$ tends to have coordination number $(\mathrm{CN})$ values of typ. 5-7, but with very varying bond lengths and presumably strengths, with only a slight tendency to reduction to typ. 5 at high $\mathrm{Bi}^{3+}$ concentrations. This reduction has little effect in practice as it only eliminates very long, weak bonds. $\mathrm{CN}=3$ is found only exceptionally, such as for a minority of $\mathrm{Bi}^{3+}$ cations in the defective sillenite $\gamma-\mathrm{Bi}_{2} \mathrm{O}_{3}$.

$\mathrm{Pb}^{2+}$ and $\mathrm{Sn}^{2+}$ are fundamentally similar to $\mathrm{Bi}^{3+}$, also being lone-pair cations. However, $\mathrm{Sn}^{2+}$ has relatively well-defined coordination shells and tends to low coordination number $(\mathrm{CN})$ values, ca. $3 . \mathrm{Pb}^{2+}$, being larger and more polarisable, behaves in a more similar way to $\mathrm{Bi}^{3+}$ in compounds; $\mathrm{CN}$ is similar to that of $\mathrm{Bi}^{3+}$ at low concentrations, but drops to 3 or 4 in $\mathrm{Pb}$ rich compounds. $\mathrm{Bi}^{3+}$ has more asymmetric bonding, having fairly high strongest-bond valences in the range $0.8-1.3$, compared to $0.6-0.7$ for $\mathrm{Pb}^{2+}$ (supplement, Table 36).

\section{Borate glasses}

The binary $x \cdot \mathrm{Bi}_{2} \mathrm{O}_{3}+(1-x) \cdot \mathrm{B}_{2} \mathrm{O}_{3}$ system has been studied most extensively; there is general agreement on several features. ${ }^{248,317,318,350,355,394,402}$

With addition of $\mathrm{Bi}_{2} \mathrm{O}_{3}$ in $\mathrm{B}_{2} \mathrm{O}_{3}$, the original $\mathrm{B}_{2} \mathrm{O}_{3}$ network, constituted of $\left[\mathrm{B}_{3} \mathrm{O}_{6}\right]$ boroxol rings and $\left[\mathrm{BO}_{3}\right]$ triangles (written $\mathrm{B}_{\Delta}$, i.e. $\mathrm{CN}=3$ ), is initially strengthened - as in other borate glasses - by conversion of part of the $\mathrm{B}_{\Delta}$ groups to tetrahedral $\left[\mathrm{BO}_{4}\right]$ ones $\left(\mathrm{B}_{\mathrm{T}}\right.$, $\mathrm{CN}=4$ ), as shown in Figure 7. Boroxol rings persist only in compositions with very low $\mathrm{Bi}_{2} \mathrm{O}_{3}$ content, and disappear for $x>25 \%$. This initial increase in the degree of bonding results - as in other borate glasses - in an increase of $T_{g}$ (Figure 3, Table 15) and network compacity $^{248,318}$ up to $x \approx 20-25 \%$.

At low $x$, an "ideal" modifier cation $\mathrm{M}^{n+}$ with valence $n$, incorporated as its oxide $\mathrm{MO}_{n / 2}$, is fully incorporated by creation of tetrahedral units:

$$
\mathrm{MO}_{n / 2}+n \cdot\left[\mathrm{BØ}_{3}\right] \rightarrow \mathrm{M}^{n+}+n \cdot\left[\mathrm{B}_{4}\right]^{-}
$$

where "Ø" is the usual convenient symbol ${ }^{350,352,404}$ for an oxygen ion making a bridging link between two network former cations (and therefore corresponding to half an oxygen atom in formulae, sometimes written " $\left.\mathrm{O}_{\frac{1}{2}}{ }^{3398}\right)$. Ideally, the fraction $N_{4}$ of $\left[\mathrm{B}_{4}\right]^{-}$tetrahedra is $n \cdot x /(1-x)$, a relation obeyed at $n \cdot x<$ ca. $25 \%$ by alkali ${ }^{405}$ and large alkaline earth $(\mathrm{Sr}, \mathrm{Ba})^{404}$ oxide additives. In contrast, $N_{4}$ is much lower than expected for $\mathrm{Bi}_{2} \mathrm{O}_{3}$, hinting at very different behaviour from that of an ideal modifier, presumably stemming from stronger preference for retaining direct covalent $\mathrm{Bi}-\mathrm{O}$ bonds over more "diffuse" ones with $\left[\mathrm{B} \varnothing_{4}\right]^{-}$tetrahedra. This behaviour also matches that of $\mathrm{SnO}$, and of other intermediate oxides such as $\mathrm{CdO}$ and $\mathrm{ZnO} .{ }^{398}$ In contrast, with $\mathrm{PbO}$ (Figure 7), $N_{4}$ behaves closer to ideal at low $x$.

For $x>$ ca. $25 \%, N_{4}$ further rises, but borate units are progressively depolymerised, as B-O-B linkages are replaced by weaker B-O-Bi ones, resulting in a drop of $T_{g}$. This behaviour is very different from simple alkali and alkaline earth borate glasses, ${ }^{404,405}$ where the peaks of $T_{g}$ and $N_{4}$ roughly coincide. $\mathrm{PbO}$ and $\mathrm{SnO}$ borate glasses also exhibit the same anomalies (Table 15), but they are much less pronounced; the exceptional structural feature in binary $\mathrm{Bi}_{2} \mathrm{O}_{3}-\mathrm{B}_{2} \mathrm{O}_{3}$ glasses is a very broad peak of $N_{4} \approx 45 \%$, which essentially extends throughout the "useful" composition range. It is therefore assumed that $\mathrm{Bi}^{3+}$ at least partly enters the network already at low $x$ values, and the borate network progressively adapts with increasing $x .^{402}$ The same is also true, but to a lesser extent, for $\mathrm{Pb}^{2+}$ and $\mathrm{Sn}^{2+}$, given the lower discrepancy between the $T_{g}$ and $N_{4}$ peaks. 
It is interesting to compare the maximum single-bond valence range for $\mathrm{Bi}^{3+}(0.8-1.3)$ and $\mathrm{Pb}^{2+}$ (0.6-0.7) in crystalline compounds with the oxygen bonding deficit for different types of bonding and different boron coordinations, accounting for the variability of ca. \pm 0.05 seen for a given B-O bond in crystalline compounds (see Table 16 and supplement 13, Table 36). Allowing for total variability of two B-O bonds, i.e. \pm 0.1 for a given $\varnothing$, some of the strongest $\mathrm{Pb}-\mathrm{O}$ bonds (0.6-0.7) may still be taken up by the bonding deficit of bridging oxygen anions bound to two borate tetrahedra $(\approx 0.5+0.1)$. This is not enough for the strongest Bi-O bonds, which will therefore favour direct linkage to the "terminal" oxygen anions of higher nominal valence, 1.00 or 1.25 (Table 16 ), the bridging oxygen ions in $\mathrm{B}_{\Delta^{-}} \varnothing-\mathrm{B}_{\mathrm{T}}$ and $\mathrm{B}_{\mathrm{T}}-\varnothing-\mathrm{B}_{\mathrm{T}}$ links being able to take up the weaker bonds for both cations. This speculative interpretation, which still requires confirmation, agrees well with observed behaviour at low $x: \mathrm{Bi}^{3+}$ has much higher deviations from "ideal-modifier" behaviour of $N_{4}$ than $\mathrm{Pb}^{2+}$, and $T_{g}$ is similar for both cations at same $x$, in spite of the higher valence of $\mathrm{Bi}^{3+}$. Also, the preference of $\mathrm{Bi}^{3+}$ for higher CNs and bond disorder agrees with conservation of high $N_{4}$ values (i.e. mixed $\mathrm{B}_{\Delta}+\mathrm{B}_{\mathrm{T}}$ ) in a wide $x$ range, compared to the more ordered crystalline phases and to $\mathrm{PbO}$, which has lower valence and favours lower CNs (Figure 7).

Anomalies in properties ${ }^{317,318,350}$ such as density and $T_{g}$ yield other hints on the structure; they are often correlated with compositions close to that of crystalline phases in the corresponding oxide systems. Based on this observation, a tendency to form local groupings in the glass similar to those that exist in the crystals was also postulated for the $\mathrm{BaO}-\mathrm{Bi}_{2} \mathrm{O}_{3}-$ $\mathrm{B}_{2} \mathrm{O}_{3}$ system, ${ }^{350}$ as typically found in borate glasses. ${ }^{402}$ Comparing data on glassy and crystallised $\mathrm{Bi}_{2} \mathrm{O}_{3}-\mathrm{B}_{2} \mathrm{O}_{3}$ samples on Figure 7 , however, one can see that this structural similitude progressively breaks down at high $x$ values, where $\mathrm{Bi}_{2} \mathrm{O}_{3}$ becomes the dominant species and obviously assumes the function of network former, with significant amounts of $\mathrm{O}^{2-}$ anions not bound to boron (i.e. only to $\mathrm{Bi}^{3+}$ ) identified at ca. $x \geq 65 \%$. ${ }^{255,394}$

In these $\mathrm{Bi}_{2} \mathrm{O}_{3}$-rich compositions, in spite of extensive characterisation work with wellcontrolled samples, there are significant discrepancies in the reported $N_{4}$ values, as illustrated in Figure 7; the work of Terashima et al. used by Dimitrov ${ }^{327}$ seems somewhat at odds with that of Bajaj et al. ${ }^{317}$ (and previous work cited by the latter ${ }^{247}$ ), although the same method (MAS-NMR) was used in both cases and sample fabrication appeared to be well-controlled (moderate melting temperatures and noble metal crucibles). Residual impurities ${ }^{317}$ could possibly account for some of the discrepancies, as well as thermal history (quenching rate and subsequent annealing), which significantly influences glass properties ${ }^{376}$ and even structure (see discussion on "polyamorphism"280, ${ }^{317}$ ); interestingly, Terashima's data lies roughly halfway between Bajaj's for glassy and crystallised samples.

Given the differences in $N_{4}$ between crystalline and glassy samples, shifts of the $\mathrm{CN}$ of $\mathrm{Bi}^{3+}$ in glass vs. in crystals can also be expected, but $\mathrm{Bi}^{3+}$ is less sensitive in this respect than $\mathrm{Pb}^{2+}$, as seen in supplement 13. In fact, most structural studies ${ }^{132,255,275,276,326,352,359,360}$ in the binary or almost binary $\mathrm{Bi}_{2} \mathrm{O}_{3}-\mathrm{B}_{2} \mathrm{O}_{3}$ system favour retention of "distorted [ $\left.\mathrm{BiO}_{6}\right]$ octahedra" throughout the composition range, and low-CN groups are not seen in $\mathrm{Bi}_{2} \mathrm{O}_{3}-\mathrm{B}_{2} \mathrm{O}_{3}$ glasses at least up to $x \approx 70 \%$. Above this level, presence of a minority of $\left[\mathrm{BiO}_{3}\right]$ groups has been reported $^{357,394}$ (threshold uncertain due to likely significant contamination from the $\mathrm{Al}_{2} \mathrm{O}_{3}$ crucible), in line with the structure of high- $\mathrm{Bi}_{2} \mathrm{O}_{3}$ crystalline boron sillenite $\mathrm{Bi}_{12}\left(\mathrm{Bi}_{0.25} \mathrm{~B}_{0.50}\right) \mathrm{O}_{19.125}$, (see supplement 13). This agrees well with $\left[\mathrm{BiO}_{3}\right]$ groups appearing together with sillenite crystallisation for ca. $x \geq 65 \%$ in heat-treated glasses. ${ }^{276,}{ }^{394}$ The reported presence of $\left[\mathrm{BiO}_{3}\right]$ groups at moderate $\mathrm{Bi}$ contents in borate, borosilicate ${ }^{362}$ and aluminoborate ${ }^{277,278}$ glasses is doubtful, and most likely results from IR peak misassignment, expected $\left[\mathrm{BiO}_{3}\right]$ peaks lying at $\approx 480$ and $840 \mathrm{~cm}^{-1}$. 276, 357, 374, 394 
Substituting some of the $\mathrm{Bi}_{2} \mathrm{O}_{3}$ with compounds such as $\mathrm{ZnO}, \mathrm{PbO}$ and $\mathrm{BaO}^{350,352,355}$ yields results very similar to that of Bajaj \& Bishay, ${ }^{247,317}$ as shown for $\mathrm{Zn}$ in Figure 7, with only slight offsets due to the elemental substitution. $\mathrm{Ba}^{2+}$ enters the glass as a modifier, ${ }^{266}$ while $\mathrm{Zn}_{406}^{2+}$ may do the same at low concentrations, ${ }^{266}$ but forms $\left[\mathrm{ZnO}_{4}\right]$ tetrahedra at high ones. ${ }^{122,}$

Concerning more complex systems, presence of $\left[\mathrm{BiO}_{3}\right]$ groups is reported in $\left(\mathrm{Li}_{2} \mathrm{O}\right)-\mathrm{ZnO}-$ $\mathrm{Bi}_{2} \mathrm{O}_{3}-\mathrm{B}_{2} \mathrm{O}_{3}{ }^{264,337,406}$ and $\mathrm{Li}_{2} \mathrm{O}-\mathrm{Bi}_{2} \mathrm{O}_{3}-\left(\mathrm{B}_{2} \mathrm{O}_{3}\right)^{334,335}$ glasses only at high $\mathrm{Bi}_{2} \mathrm{O}_{3}$ and low $\mathrm{B}_{2} \mathrm{O}_{3}$ contents, $\mathrm{Bi}^{3+}$ being otherwise present as $\left[\mathrm{BiO}_{6}\right]$ only.

Compared to $\mathrm{Bi}^{3+}$, the coordination of $\mathrm{Pb}^{2+}$ is somewhat more ordered and much more dependent on $x$ in binary borate glasses, according to XRD and MAS-NMR studies: ${ }^{397} \mathrm{CN}$ is 6 up to ca. $x=25 \%$, then decreases continuously, reaching 3 for $x \geq \approx 55 \%$, which is matched by a corresponding decrease of average bond length from $\approx 300$ down to $233 \mathrm{pm}$. $\mathrm{Pb}^{2+}$ is therefore roughly present as $\left[\mathrm{PbO}_{6}\right]$ octahedra and behaves somewhat as a classical modifier at low $x$, and progressively switches at higher $x$, well within the vitrification range, to $\left[\mathrm{PbO}_{3}\right]$ network-forming trigonal pyramids (3-PyM), with fewer, stronger $\mathrm{Pb}-\mathrm{O}$ bonds. However, while the average bond length found for $\left[\mathrm{PbO}_{3}\right]$ agrees well with bonding in Pb-rich crystalline compounds (supplement 13 ), the corresponding length for $\left[\mathrm{PbO}_{6}\right]$ is clearly too long, which suggests bonding is also somewhat inhomogeneous at low $x$ (existence of shorter bonds). This, together with $N_{4}$ being slightly less than ideal and $T_{g}$ starting to drop at lower $x$ values than the $\mathrm{CN}$, hints at some departure of $\mathrm{Pb}^{2+}$ from pure modifier behaviour, even at low $x$, albeit to a much lesser extent than $\mathrm{Bi}^{3+}$. At high $x$, there is also some ambiguity in the 3 -PyM configuration, as there are additional, weaker bonds, as seen in the crystals; ${ }^{407}$ the configuration can be viewed as 4-PyM (more $3+1$, with one longer bond), with additional, much longer ones above the pyramid apex.

\section{Silicate and germanate glasses}

The case of silicate ${ }^{408}$ and germanate ${ }^{231,374,393,409}$ glasses is much simpler, as the $\left[\mathrm{SiO}_{4}\right]$ and [ $\left.\mathrm{GeO}_{4}\right]$ tetrahedra are conserved when $\mathrm{Bi}_{2} \mathrm{O}_{3}$ is added, with no reported formation of $\left[\mathrm{GeO}_{6}\right]$ octahedra as found in the alkaline germanate glasses. The only change is gradual weakening of the original network, as attested by the continuous drop of $T_{g}$ with increasing $x$ in the $x \cdot \mathrm{BiO}_{1.5}+(1-x) \cdot(\mathrm{Ge}, \mathrm{Si}) \mathrm{O}_{2}$ system, as shown in Figure 3 for silicates. Absence of $\left[\mathrm{GeO}_{6}\right]$ octahedra was also reported in complex germanate glasses, with $\mathrm{V}_{2} \mathrm{O}_{5},{ }^{231} \mathrm{Ga}_{2} \mathrm{O}_{3}{ }^{359,}{ }^{360}$ and $\mathrm{PbO}-\mathrm{Ga}_{2} \mathrm{O}_{3}{ }^{370}$ additions.

$\mathrm{Bi}^{3+}$ is generally reported as being present in the form of $\left[\mathrm{BiO}_{6}\right]$ groups, but also as $\left[\mathrm{BiO}_{5}\right]$, from XAS spectra and molecular dynamics (MD) calculations. ${ }^{408}$ Given the very high disorder around $\mathrm{Bi}^{3+}$, this difference in reported structure is probably not very significant. As for borates, no $\left[\mathrm{BiO}_{3}\right]$ groups were found to high $x$ values $(80 \%)$ in $\mathrm{Bi}_{2} \mathrm{O}_{3}-\mathrm{GeO}_{2}\left(-\mathrm{Eu}_{2} \mathrm{O}_{3}\right)$ glasses. On the other hand, after heat treatment and crystallisation, $\left[\mathrm{BiO}_{3}\right],\left[\mathrm{BiO}_{6}\right],\left[\mathrm{GeO}_{4}\right]$ and $\left[\mathrm{GeO}_{6}\right]$ groups appeared, with $\mathrm{Bi}_{2} \mathrm{GeO}_{5}, \mathrm{Bi}_{4} \mathrm{Ge}_{3} \mathrm{O}_{12}$ and unidentified peaks seen in the XRD spectra. ${ }^{374}$ Neither $\left[\mathrm{BiO}_{3}\right] 3-\mathrm{PyM}$ pyramids nor $\left[\mathrm{GeO}_{6}\right]$ octahedra exist in the identified crystalline structures (supplement 13), but this apparent conflict may be resolved for $\left[\mathrm{BiO}_{3}\right]$, assuming some of the unidentified crystalline phase is the $\left[\mathrm{BiO}_{3}\right]$-containing $\mathrm{Ge}$ sillenite $\mathrm{Bi}_{12} \mathrm{GeO}_{20}$, whose formation would be expected at $x=80 \%$, as seen in borates. ${ }^{276,394}$ The presence of $\left[\mathrm{GeO}_{6}\right]$ is more doubtful, as it is also absent in sillenite and $\mathrm{Bi}_{2} \mathrm{Ge}_{3} \mathrm{O}_{9}$ as well, but could be possible in the residual glass due to the thermal history or in an unidentified metastable phase.

The existence of $\left[\mathrm{GeO}_{6}\right.$ ] groups in $\mathrm{PbO}-\mathrm{GeO}_{2}$ glasses has been reported, albeit to a much lower extent than in the alkali germanates, ${ }^{12,410}$ but more recent work ${ }^{409}$ concludes to all $\mathrm{Ge}^{4+}$ 
being in $\left[\mathrm{GeO}_{4}\right]$ tetrahedra. There is basic consensus that $\mathrm{Pb}^{2+}$ forms $\left[\mathrm{PbO}_{3 / 4}\right]$ (3/4-PyM) pyramids in $\mathrm{Pb}$-rich $\mathrm{PbO}-\mathrm{SiO}_{2}{ }^{407,} 411,412$ and $\mathrm{PbO}-\mathrm{GeO}_{2}{ }^{413}$ glasses. On the other hand, $\mathrm{Pb}^{2+}$ coordination at lower lead contents has been questioned recently. $\mathrm{CN}=6$ was found at up to $40 \% \mathrm{PbO}$ in $\mathrm{PbO}-\mathrm{GeO}_{2},{ }^{410}$ and progressive switch from network modifier to former behaviour (presumably $\left[\mathrm{PbO}_{6}\right] \rightarrow\left[\mathrm{PbO}_{3 / 4}\right]$ ) up to $40 \% \mathrm{PbO}$ in $\mathrm{PbO}-\mathrm{SiO}_{2}{ }^{414}$ Somewhat at odds with these results, $\mathrm{Pb}^{2+}$ was found to form $\left[\mathrm{PbO}_{3 / 4}\right]$ pyramids down to $30 \% \mathrm{PbO}$ in $\mathrm{PbO}-$ $\mathrm{SiO}_{2},{ }^{412}$ a behaviour similar to that found in $\mathrm{SnO}-\mathrm{SiO}_{2}$ glasses, where $\mathrm{Sn}^{2+}$ essentially appears in 3-PyM coordination, with $\mathrm{CN}$ only slightly increasing at low $\mathrm{SnO}$ contents. ${ }^{415}$

\section{Phosphate glasses}

The binary $\mathrm{Bi}_{2} \mathrm{O}_{3}-\mathrm{P}_{2} \mathrm{O}_{5}$ system has received only scant attention due to its limited vitrification range, which probably stems from easy crystallisation of high-melting $\mathrm{BiPO}_{4} ;{ }^{377} \mathrm{Bi}_{2} \mathrm{O}_{3}$ is therefore mostly found as an additive (intended or as waste ${ }^{96,98}$ ) in multicomponent glasses.

Replacing part of $\mathrm{Fe}^{3+}$ in a $40 \mathrm{Fe}_{2} \mathrm{O}_{3}-60 \mathrm{P}_{2} \mathrm{O}_{5}$ glass with isovalent $\mathrm{Bi}^{3+}$ is found to effect only limited changes to the structure, ${ }^{228}$ expectedly, the phosphate groups are mostly present as $\mathrm{Q}_{1}$ pyrophosphate units, ${ }^{209,210}$ and both $\mathrm{Fe}^{3+}$ and $\mathrm{Bi}^{3+}$ are present as hexacoordinated octahedral units. Similar incorporation as $\left[\mathrm{BiO}_{6}\right]$ was determined for $\mathrm{ZnO}-\mathrm{Bi}_{2} \mathrm{O}_{3}-\mathrm{P}_{2} \mathrm{O}_{5}{ }^{262}, 265,267$ and $\mathrm{Li}_{2} \mathrm{O}-\mathrm{Bi}_{2} \mathrm{O}_{3}-\mathrm{P}_{2} \mathrm{O}_{5}{ }^{378}$ glasses. As for the other systems, $\mathrm{Bi}_{2} \mathrm{O}_{3}$ was concluded to behave partly as a network former. In comparison, $\mathrm{SnO}$ in 3-PyM coordination can also enter the glass network, being able to vitrify with fully depolymerised phosphate groups. ${ }^{218}$

\section{Gallate glasses}

$\mathrm{Ga}^{3+}$ is found to form $\left[\mathrm{GaO}_{4}\right]$ tetrahedral groups in $\mathrm{HMO}$ glasses throughout the ternary PbO$\mathrm{Bi}_{2} \mathrm{O}_{3}-\mathrm{Ga}_{2} \mathrm{O}_{3}{ }^{109}, 111,385,386$ and $\mathrm{Bi}_{2} \mathrm{O}_{3}-\mathrm{Ga}_{2} \mathrm{O}_{3}-\mathrm{B}_{2} \mathrm{O}_{3}{ }^{359,360}$ systems, as well as more complex $\mathrm{PbO}-\left(\mathrm{PbF}_{2}\right)-\mathrm{Bi}_{2} \mathrm{O}_{3}-\mathrm{Ga}_{2} \mathrm{O}_{3}-\mathrm{GeO}_{2}{ }^{370,371}$ compositions, with good agreement of $\mathrm{Ga}-\mathrm{O}$ bond lengths with those found in crystals. ${ }^{109,111} \mathrm{As}$ in other $\mathrm{HMO}$-rich systems, $\mathrm{Bi}^{3+}$ and $\mathrm{Pb}^{2+}$ are reported to form "[ $\left.\mathrm{BiO}_{6}\right] "$ groups and $\left[\mathrm{PbO}_{3 / 4}\right]$ (3/4-PyM) pyramids respectively, with a higher degree of disorder around $\mathrm{Bi}^{3+}$.

In these glasses, coordination around $\mathrm{Bi}^{3+}$ and $\mathrm{Pb}^{2+}$ has been examined more extensively. Assignment of Raman bands for $\mathrm{Bi}-\mathrm{O}$ bonds ${ }^{360}$ agrees with the $\mathrm{Bi}^{3+}$ bonding in crystals (Supplement 13, deformed 5-Py14 pyramids), with a short apical bond, and 2 groups of unequal bonds on either side of the pyramid base. The last, much weaker bond assigned in glasses to complete a "[ $\left.\mathrm{BiO}_{6}\right]$ octahedron" could actually correspond to a pair, as found in the 7-Py142 configuration often reported in crystals. These results also agree very well with detailed neutron \& XRD studies of a binary $80 \mathrm{BiO}_{1.5}+20 \mathrm{GaO}_{1.5}$ glass, ${ }^{109}$ which yield $\mathrm{CN} \approx 5$ for $\mathrm{Bi}^{3+}$, with roughly 1,2 and 2 oxygen anions at 213,224 and $252 \mathrm{pm}$ respectively. Obviously, $\mathrm{CN}$ of $\mathrm{Bi}^{3+}$ stays high even for a very Bi-rich glass, influencing the $\mathrm{CN}$ of $\mathrm{Pb}^{2+}$ in the ternary $\mathrm{PbO}-\mathrm{Bi}_{2} \mathrm{O}_{3}-\mathrm{Ga}_{2} \mathrm{O}_{3}$ system, which was found to decrease from 3.5 for $\mathrm{Bi}$-free glasses to 3.0 for Bi-rich ones. ${ }^{111}$ This is logical, as the higher oxygen $\mathrm{CN}$ of $\mathrm{Bi}^{3+}$ creates a severe oxygen shortage, which is partly compensated by decrease of $\mathrm{Pb}^{2+} \mathrm{CN}$. Nevertheless, in all these $\mathrm{HMO}$-rich glasses, $\mathrm{CN}>2$ for oxygen, with $\mathrm{CN}=3.5$ for the binary $80 \mathrm{BiO}_{1.5}+20 \mathrm{GaO}_{1.5}$ glass.

\section{Other glasses}

Vanadate $^{231,232}$ and molybdate ${ }^{232,234}$ glasses exhibit a change of network former coordination polyhedra when adding $\mathrm{Bi}_{2} \mathrm{O}_{3}:\left[\mathrm{VO}_{5}\right]$ trigonal bipyramids and $\left[\mathrm{MoO}_{6}\right]$ octahedra are converted to $\left[\mathrm{VO}_{4}\right]$ and $\left[\mathrm{MoO}_{4}\right]$ tetrahedra respectively. Tellurates are even more complex, and tend to integrate only little $\mathrm{Bi}_{2} \mathrm{O}_{3}$, together with a $3^{\text {rd }}$ oxide; the original irregular $\left[\mathrm{TeO}_{4}\right]$ trigonal bipyramid (4-BPy, $\mathrm{Te}^{4+}$ also being a lone-pair ion) of $\mathrm{TeO}_{2}$ is partly converted, 
depending on $\mathrm{Bi}_{2} \mathrm{O}_{3}$ and other oxides, to $\left[\mathrm{TeO}_{3}\right]$ (3-PyM) pyramids and $\left[\mathrm{TeO}_{3+1}\right]$ polyhedra. ${ }^{120,126,237,239,240} \mathrm{Bi}^{3+}$ is reported to form "[BiO 6$] "$ groups, as with standard network formers.

\section{Glasses without network formers}

Structural studies on systems where mainly $\mathrm{Bi}_{2} \mathrm{O}_{3}$ forms the network are relatively scarce. In $\mathrm{Li}_{2} \mathrm{O}-\mathrm{Bi}_{2} \mathrm{O}_{3}$ glasses, a disordered local structure, analogous to crystalline $\mathrm{Bi}_{2} \mathrm{O}_{4}$, was assumed; it was rationalised that the nominal additional oxygen was provided by $\mathrm{Li}_{2} \mathrm{O}$, and even very atypical partial oxidation to $\mathrm{Bi}^{5+}$ (see supplement 12 ), the rest being compensated by defects.

Structural analysis of glasses based on a nominal $89 \mathrm{BiO}_{1.5}+11 \mathrm{PbO}$ formulation, probably contaminated with $\mathrm{Al}_{2} \mathrm{O}_{3}$ from the crucible and optionally doped with $\mathrm{MnO}_{y}$, expectedly yields coordination of $\mathrm{Pb}^{2+}$ as $\left[\mathrm{PbO}_{3 / 4}\right](3 / 4-\mathrm{PyM})$ groups. $\mathrm{Bi}^{3+}$ was found in the Mn-free glass mainly as $\left[\mathrm{BiO}_{6}\right]$ groups, with a minority of $\left[\mathrm{BiO}_{3}\right]$. However, the reported exclusive formation of $\left[\mathrm{BiO}_{3}\right]$ pyramids in $\mathrm{Mn}$-doped glass must be taken with caution, as this does not correspond to any relevant Bi-based compound.

\section{Conclusions}

Concerning the coordination of $\mathrm{Bi}^{3+}$ in glass, most infrared and Raman spectroscopic studies on conclude that $\mathrm{Bi}^{3+}$ essentially forms distorted $\left[\mathrm{BiO}_{6}\right](\mathrm{CN} \approx 6)$ octahedral-like configuration, with little variation of $\mathrm{CN}$ over a wide concentration range; a minority of $\left[\mathrm{BiO}_{3}\right]$ pyramids is found only in very Bi-rich compositions, in agreement with their presence in the sillenite crystalline structure (see supplement 13 ). The term "[ $\left.\mathrm{BiO}_{6}\right]$ octahedron" must be taken with proper caution, as coordination around $\mathrm{Bi}^{3+}$ tends to be ill-defined; more dedicated studies ${ }^{109,408}$ yield $\mathrm{CN} \approx 5$ with nonuniform bond lengths, corresponding to a deformed octahedron with an oxygen vertex replaced by the $\mathrm{Bi}^{3+}$ lone pair $\mathrm{E}$ and thus yielding a $\left[\mathrm{BiO}_{5} \mathrm{E}\right]$ unit (Figure 8, 5-Py14 configuration). This agrees well with assignment of Raman bands; ${ }^{360}$ the additional Raman band attributed to a further, weaker bond could in fact correspond to two such bonds, matching the 7-Py142 configuration often found in crystalline compounds.

The high $\mathrm{CN}$ maintained by $\mathrm{Bi}^{3+}$ to high concentrations necessitates a $\mathrm{CN}$ of $\mathrm{O}^{2-}$ greater than 2 , apparently violating the classical rules for glass formation. ${ }^{416}$ This is also true for $\mathrm{Pb}^{2+}$ and $\mathrm{Sn}^{2+}$, which have lower $\mathrm{CN}$ but lower valence as well. However, in contrast to $\mathrm{Bi}^{3+}$ and $\mathrm{Sn}^{2+}$, coordination around $\mathrm{Pb}^{2+}$ is seen - at least in some cases such as the $\mathrm{PbO}-\mathrm{Bi}_{2} \mathrm{O}_{3}-\mathrm{Ga}_{2} \mathrm{O}_{3}$ and $\mathrm{PbO}-\mathrm{B}_{2} \mathrm{O}_{3}$ systems - to be more dependent on the local environment and available oxygen to bond to.

A comparison of the analogous divalent and trivalent lone-pair cations (Table 17) sheds new light into their structural features and trends. In line with original predictions, ${ }^{416}$ the rigid 3-PyM oxygen coordination shell of the lightest trivalent cation, $\mathrm{As}^{3+}$, makes it a classical network former, as is (almost) the case for $\mathrm{Sb}^{3+}$, whose coordination is somewhat less rigid. ${ }^{417,418} \mathrm{Sn}^{2+}$ is relatively rigid and favours a similar coordination, but intrinsically cannot form a glass on its own due to its valence being lower than its $\mathrm{CN}$. Note that $\mathrm{As}^{3+}, \mathrm{Sb}^{3+}$ and $\mathrm{Sn}^{2+}$ are not stable in air, and $\mathrm{Sn}^{2+}$ tends to disproportionate into $\mathrm{Sn}^{0}$ and $\mathrm{Sn}^{4+}$.

The larger polarisable cations, $\mathrm{Pb}^{2+}$ and $\mathrm{Bi}^{3+}$ have much more variable and disorderly coordination shells, with $\mathrm{CN}$ behaving somewhat the same way as in crystals, i.e. being somewhat concentration-dependent for $\mathrm{Pb}^{2+}$, and less so for $\mathrm{Bi}^{3+}$. Nevertheless, a tendency remains to form a limited number (3-4) of comparatively stronger bonds. One can speculatively view this inhomogeneous metal-oxygen bonding as a reflection of the ambiguous behaviour of these cations, as both network formers (through the stronger metal- 
oxygen bonds) and network modifiers (through the weak ones); considering the strong bonds only reduces the $\mathrm{CN}$ of oxygen, making it more compatible with classical rules of glass formation. More studies are clearly needed to arrive at a better definition of these complex and disordered coordination environments, possibly assisted by MD simulations ${ }^{408}$ coupled with cation-oxygen interactions based on recent revisons ${ }^{403}$ (see also supplement 13) of lonepair bonding in crystals. 


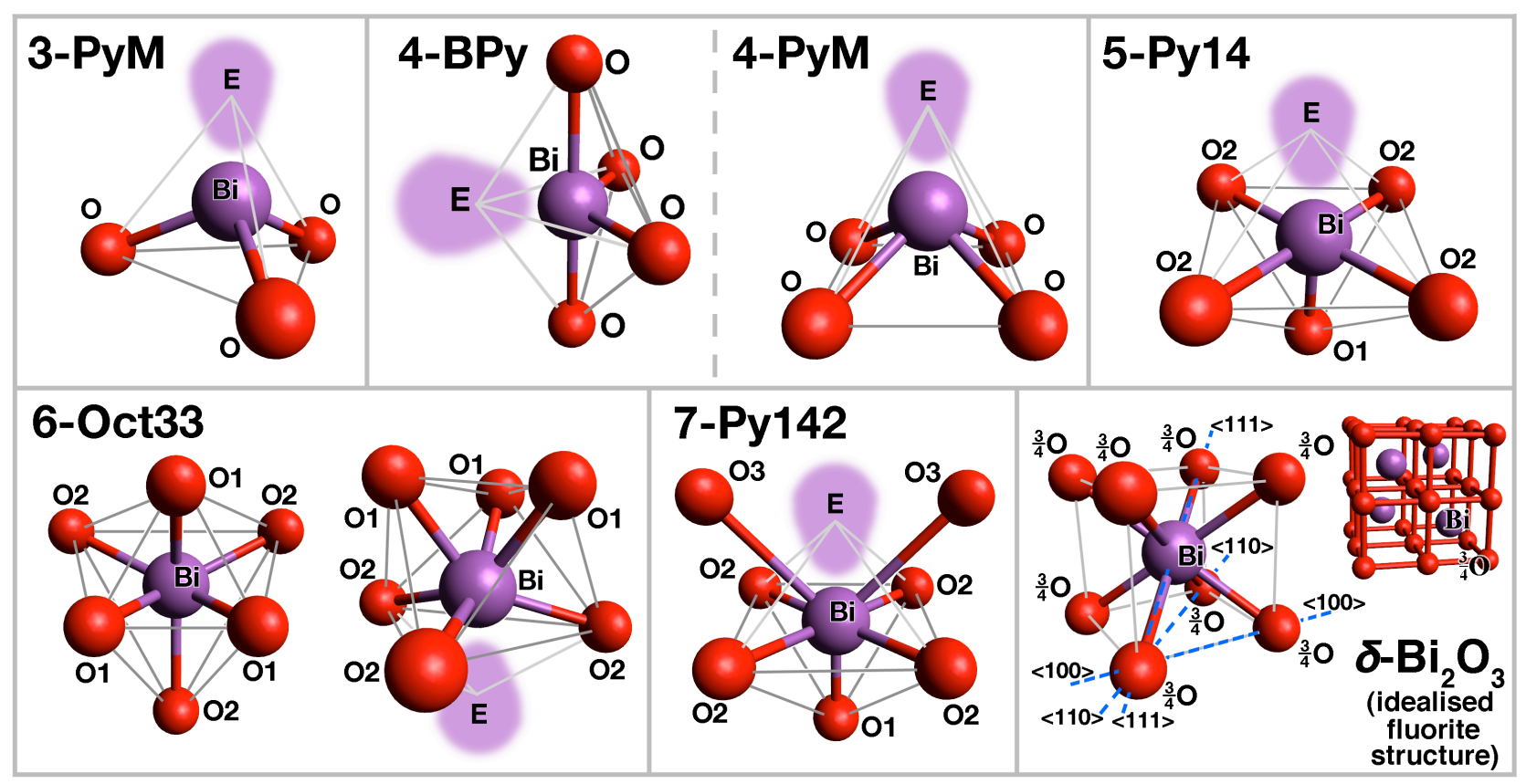

Figure 6. Some oxygen coordination shells around $\mathrm{Bi}$ observed in crystalline oxides (see supplement 13 and Table 14). $\mathrm{E}=\mathrm{Bi}^{3+}$ lone-pair electrons.

Table 14. Description of oxygen coordination shells around $B i$ observed in crystalline oxides (see supplement 13 and Figure 6). $\mathbf{E}$ stands for the $\mathrm{Bi}^{\mathbf{3 +}}$ lone-pair electrons.

\begin{tabular}{|c|c|}
\hline Designation & Description \\
\hline 3-PyM & Trigonal pyramid with $\mathrm{Bi}$ apex / $\mathrm{Bi}\left(\mathrm{O}_{3} \mathrm{E}\right)$ tetrahedron \\
\hline 4-Py13 & $\begin{array}{l}\text { Trigonal pyramid with base around } \mathrm{Bi}(\mathrm{O} 1=\text { apex, } 3 \times \mathrm{O} 2=\text { base; } \mathrm{E} \text { directed opposite to apex, } \\
\text { through base }) / \mathrm{Bi}\left(\mathrm{O}_{4} \mathrm{E}\right) \text { trigonal bipyramid }\end{array}$ \\
\hline 4-BPy & Face-sharing bipyramid with $\mathrm{Bi}$ apex / $\mathrm{Bi}\left(\mathrm{O}_{4} \mathrm{E}\right)$ trigonal bipyramid \\
\hline 4-PyM & Square pyramid with $\mathrm{Bi}$ apex / $\mathrm{Bi}\left(\mathrm{O}_{4} \mathrm{E}\right)$ square pyramid \\
\hline 5-Py14 & $\begin{array}{l}\text { Square pyramid with base around } \mathrm{Bi}(\mathrm{O} 1=\text { apex, } 4 \times \mathrm{O} 2=\text { base; E directed opposite to apex, } \\
\text { through base }) / \mathrm{Bi}\left(\mathrm{O}_{5} \mathrm{E}\right) \text { octahedron }\end{array}$ \\
\hline $6-\mathrm{Oct}$ & Octahedron (in general) \\
\hline $6-O c t 33$ & $\begin{array}{l}\text { Irregular octahedron with } 3 \text { short }(\mathrm{O} 1) \text { and } 3 \text { long }(\mathrm{O} 2) \text { bonds (E through the large triangle } \\
\text { formed by } 3 \times \mathrm{O} 2)\end{array}$ \\
\hline $6-O c t 222$ & Another form of irregular octahedron, with bond lengths in $2+2+2$ order \\
\hline 7-Py142 & Same as 5-Py14, with 2 additional longer bonds (O3) below the pyramid base \\
\hline 7-PyM34 & Same as 3-PyM, with 4 longer, irregular bonds opposite of apex \\
\hline 7-PyM43 & Same as 4-PyM, with 3 longer, irregular bonds opposite of apex \\
\hline$\delta-\mathrm{Bi}_{2} \mathrm{O}_{3}$ & $\begin{array}{l}\text { Idealised cubic oxygen shell in the high-temperature } \delta \text { polymorph of } \mathrm{Bi}_{2} \mathrm{O}_{3} \text { (fluorite } \\
\text { structure), with } 6 / 8 \text { oxygen site occupation and possible vacancy arrangements }\end{array}$ \\
\hline $8-\mathrm{C} 26 \mathrm{~s}$ & $\begin{array}{l}\text { Cubic environment }\left(\delta-\mathrm{Bi}_{2} \mathrm{O}_{3} \text { with all oxygen sites occupied }\right) \text {, with two shorter bonds along } \\
{[111] \text {, i.e. apparently symmetric }}\end{array}$ \\
\hline 9-Pr333 & Tricapped trigonal prism, asymmetric, with three triangles of different bonding lengths \\
\hline
\end{tabular}




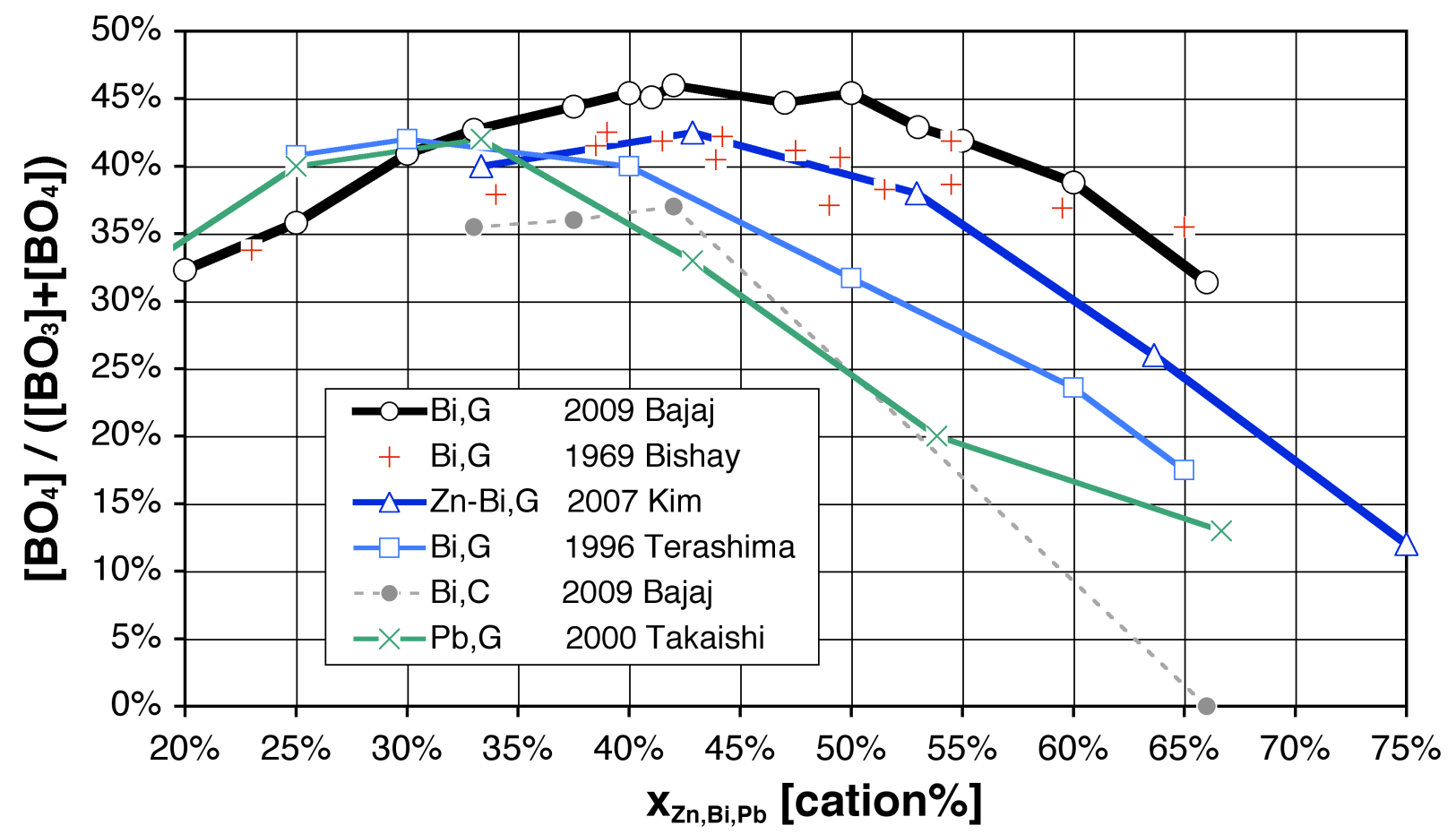

Figure 7. $\left[\mathrm{BO}_{4}\right]$ tetrahedra fraction $N_{4}$ in boron coordination polyhedra $\left(\left[\mathrm{BO}_{3}\right]\right.$ and $\left.\left[\mathbf{B O}_{4}\right]\right)$, for $\mathrm{Bi}_{2} \mathbf{O}_{3}-\mathrm{B}_{2} \mathbf{O}_{3}$ glass $\left({ }^{317}++^{247} \square^{327}\right) \&$ crystallised glass $\left({ }^{317}\right),\left(\mathrm{ZnO} \cdot \mathbf{B i}_{2} \mathbf{O}_{3}\right)-\mathbf{B}_{2} \mathbf{O}_{3}$ glass $\left(\Delta^{355}\right)$ and $\mathrm{PbO}_{-} \mathrm{B}_{2} \mathrm{O}_{3}$ glass $\left(\times^{397}\right)$.

Table 15. $T_{g}$ and $N_{4}$ peaks in binary $x \cdot\left(\mathrm{BiO}_{1.5}, \mathrm{SbO}_{1.5}, \mathrm{PbO}, \mathrm{SnO}\right)-(1-x) \cdot \mathrm{BO}_{1.5}$ glasses.

\begin{tabular}{lcccc}
\hline System & $\mathbf{B i}_{2} \mathbf{O}_{3}-\mathbf{B}_{2} \mathbf{O}_{3}{ }^{317}$ & $\begin{array}{c}\mathbf{S b}_{2} \mathbf{O}_{3}- \\
\mathbf{B}_{2} \mathbf{O}_{3}{ }^{418}\end{array}$ & $\mathbf{P b O}-\mathbf{B}_{2} \mathbf{O}_{3}{ }^{397}$ & $\mathbf{S n O}-\mathbf{B}_{2} \mathbf{O}_{3}{ }^{398}$ \\
\hline Peak $T_{g}(x)$ & $469^{\circ} \mathrm{C}(23 \%)$ & $300^{\circ} \mathrm{C}(50 \%)$ & $460{ }^{\circ} \mathrm{C}(17 \%)$ & $384^{\circ} \mathrm{C}(23 \%)$ \\
\hline Peak $N_{4}(x)$ & $\approx 45 \%(38-50 \%)$ & $11 \%(50 \%)$ & $42 \%(30 \%)$ & $28 \%(33 \%)$ \\
\hline "Ideal" $x$ & $25 \%$ & (see note) & $33 \%$ & $33 \%$
\end{tabular}

Note. $\mathrm{Sb}_{2} \mathrm{O}_{3}\left(\mathrm{Sb}^{3+}\right)$ is close to being a true glass former $-\mathrm{B}_{\mathrm{T}}$ possibly due to observed presence of $\mathrm{Sb}^{5+}$ ions. 
Th. Maeder - IMR 2012 - Review of $\mathrm{Bi}_{2} \mathrm{O}_{3}$-based glasses (9.10.2012) - 36

Table 16. Nominal bonding deficit of oxygen anions in borate glasses vs. structure.

\begin{tabular}{lc}
\hline Oxygen bond & $\begin{array}{c}\text { O / Ø nominal } \\
\text { bonding deficit } \\
\text { [valence units] }\end{array}$ \\
\hline $\mathrm{B}_{\Delta}-\varnothing-\mathrm{B}_{\Delta}$ & 0.00 \\
\hline $\mathrm{B}_{\Delta}-\varnothing-\mathrm{B}_{\mathrm{T}}$ & 0.25 \\
\hline $\mathrm{B}_{\mathrm{T}}-\varnothing-\mathrm{B}_{\mathrm{T}}$ & 0.50 \\
\hline $\mathrm{B}_{\Delta}-\mathrm{O}^{-}$ & 1.00 \\
\hline $\mathrm{B}_{\mathrm{T}}-\mathrm{O}^{-}$ & 1.25 \\
\hline $\mathrm{O}^{2-}$ & 2.00 \\
\hline
\end{tabular}

Table 17. Oxygen coordination trends of "lone-pair" cations vs. concentration $x$.

\begin{tabular}{|c|c|c|c|c|c|}
\hline Shell & & +2 & $x$ & +3 & \\
\hline & Ion & Coord. $^{\mathrm{a}}$ & & Coord. $^{a}$ & Ion \\
\hline $4 s^{2}$ & - & - & (All) & 3-РyМ & $\mathrm{As}^{3+}$ \\
\hline $5 s^{2}$ & $\mathbf{S n}^{2+}$ & 3-РyМ & (All) & 3-РyМ & $\mathbf{S b}^{3+}$ \\
\hline $6 s^{2}$ & $\mathbf{P b}^{2+}$ & $\begin{array}{c}3 / 4-\mathrm{PyM}^{\mathrm{b}} \\
\approx 6^{\mathrm{d}}\end{array}$ & $\begin{array}{l}\text { High } \\
\text { Low }\end{array}$ & $\begin{array}{c}5-\mathrm{Py} 14^{\mathrm{c}} \\
\approx 5-7^{\mathrm{d}}\end{array}$ & $\mathrm{Bi}^{3+}$ \\
\hline
\end{tabular}

Notes
a) Coordination shells: see Figure $6 \&$ Table 14
b) 4-PyM often 3+1 (1 longer bond)
c) 5-Py14 often $1+2+2$ ( 1 short, 2 medium, 2 long bonds); exceptionally 3 -PyM as in sillenites.
d) Variable, disordered oxygen coordination shells, more so for $\mathrm{Bi}^{3+}$ than for $\mathrm{Pb}^{2+}$ 


\subsection{Oxidoreduction issues}

Possible reduction of $\mathrm{Bi}^{3+}$ to metal during glass preparation, ${ }^{118}$ and later during processing, for instance through transient reducing conditions brought about by binder burnout, is even more pronounced than for $\mathrm{Pb}^{2+}$, as $\mathrm{Bi}_{2} \mathrm{O}_{3}$ is even less stable towards reduction than $\mathrm{PbO}{ }^{59}$, 419-422 This can be a problem for processing, especially of low-melting glasses due to difficulty in burning out the organics. One must however mention that precious metal oxides used in TFRs, such as $\mathrm{RuO}_{2}$, are even much less stable towards reduction (see PDC-5015) than $\mathrm{Bi}_{2} \mathrm{O}_{3}$, so $\mathrm{Bi}_{2} \mathrm{O}_{3}$ reduction is not the limiting problem overall for standard air-firing thickfilm electronics. ${ }^{423}$ Finally, a moderate sensitivity to reduction actually can be beneficial in some respects, especially solderability of conductors (see section 4.5).

Unfortunately, information about the thermodynamics of $\mathrm{Bi}_{2} \mathrm{O}_{3}$ (and other oxides) in glasses is rather limited: polarimetric studies were carried out ${ }^{424}$ on a borosilicate glass with very low $(0.25 \% \mathrm{~mol}) \mathrm{Bi}_{2} \mathrm{O}_{3}$ additions, but the results are not directly applicable to glasses where $\mathrm{Bi}_{2} \mathrm{O}_{3}$ is one of the main components, as those concerned in the present work. Nevertheless, recent reduction experiments ${ }^{366,408,425-427}$ and results of high-temperature firing ${ }^{118,375}$ do confirm easy reduction and formation of $\mathrm{Bi}^{0}$ nanoparticles, or, for glasses doped with low amounts $\mathrm{Bi}$, presumably reduced species, whose nature is still subject to debate. ${ }^{428-430}$

Control of reduction, as in more common industrial glasses, may be achieved by "fining agents", i.e. oxidoreduction buffers that inhibit reduction to $\mathrm{Bi}^{0}$ under practical firing conditions; this has been shown to be successful with low $\mathrm{Sb}, \mathrm{As}$, Ce or $\mathrm{Cu}$ additions, ${ }^{112,114}$, 273, 361, 431 with $\mathrm{CeO}_{2}$ often found in the patent literature. ${ }^{311,314,432}$ Alternatively, using a fugitive oxidant such as $\mathrm{KClO}_{4}$ and $\mathrm{KNO}_{3}$ allows controlled reduction and precipitation of $\mathrm{Bi}^{0}$ nanoparticles to create a well-defined surface plasmon resonance (SPR) band. ${ }^{427}$ Additionally, the other main glass constituents, by affecting the overall basicity of the glass, will also somewhat influence the tendency of $\mathrm{Bi}^{3+}$ towards reduction. ${ }^{399,430}$

Finally, further oxidoreduction issues involving interaction with adjacent layers, such as adhesion on metal (section 4.4), staining of glasses by in-diffusion from Ag conductors (4.2) and contacts to PV cells (4.5), as well as optical properties, are discussed in the corresponding sections. Also, a strong point is made in supplement 12 against - except in unusual circumstances - the occasionally reported presence of significant amounts of $\mathrm{Bi}^{5+}$ in glasses. 


\section{Applications in layer form}

This section discusses in more detail the application of $\mathrm{Bi}_{2} \mathrm{O}_{3}$-based glasses, using thick-film or similar technology, to electronics, automotive and architectural glass, display panels and photovoltaics. Uses in bulk form are discussed in section 5. The present discussion will mostly concentrate on materials covering the low processing temperature range, the main application of the $\mathrm{Bi}_{2} \mathrm{O}_{3}$-based glasses and the $\mathrm{PbO}$-based ones they should replace.

Parts 4.1 to 4.4 discuss applications of insulating glass-based layers in the four main configurations illustrated in Figure 8, each corresponding to a specific role for the glass-based layer and determining the required behaviour during firing and the insulating characteristics: A) sealing, B) overglazing / enamelling, C) multilayer dielectrics and D) dielectrics for insulating metal substrates. Part 4.1 also discusses glass stability upon refiring, as lowtemperature sealing is the most demanding application in this respect. Finally, parts 4.5 and 4.6 discuss conductors / metallisations, and TFRs respectively.

\subsection{Sealing \& glass stability during reflow}

Sealing stands apart from the other applications in that the sealing material must ideally be able to flow extensively during processing, in contrast to the other applications, where densification only is to be achieved. In the classical leaded sealing glasses, some of the $\mathrm{PbO}$ is often replaced by $\mathrm{Bi}_{2} \mathrm{O}_{3}$ to improve flowability, ${ }^{150,151,242}$ stability against devitrification and compatibility with temperature-lowering fluoride additions, ${ }^{149}$ or even strength, ${ }^{152}$ However, as discussed in section 3.1, replacing most or all of the $\mathrm{PbO}$ by $\mathrm{Bi}_{2} \mathrm{O}_{3}$ results in increased viscosity, ${ }^{149}$ which may in most cases be mitigated by alkaline or fluoride additions to the extent durability and stability is not excessively degraded. As possible conductors going through the seal are usually only in a side-by-side configuration (Figure 8A), insulating properties should not be critical in most applications, except in PDPs, ${ }^{181,308}$ where conductors are on both sides.

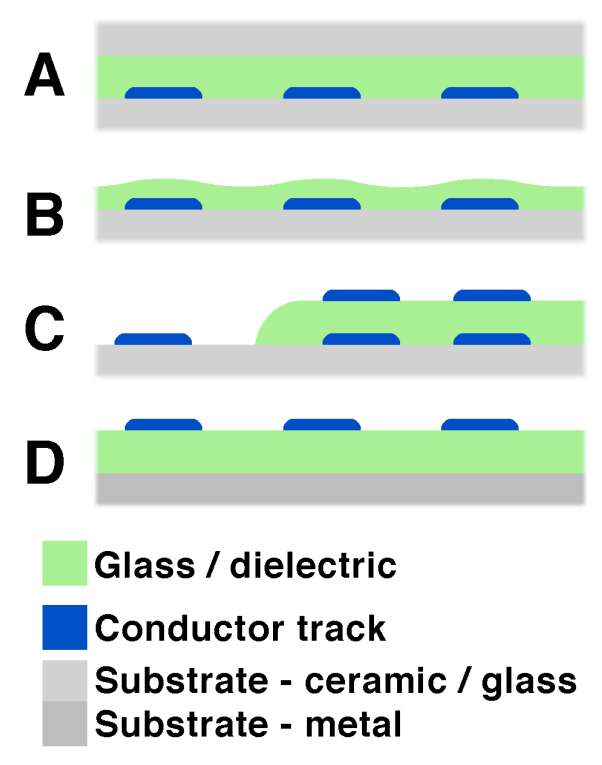

Figure 8. Typical configurations / roles for dielectric glass-based layers: A) sealing glass; B) overglaze; C) multilayer dielectric; D) insulating dielectric on metallic substrate. 
Sealing glass may be formulated to be either stable or devitrifying. ${ }^{15,18,74}$ Ideally, devitrifying seals yield the best properties, but they also tend to have tight processing requirements, limited flowability and are usually not applicable for low-temperature sealing, where "composite" glasses are used, i.e. stable glasses with low-expansion fillers to adjust the CTE. ${ }^{18}$ In any case, extensive flow must be insured without or before crystallisation, which means sealing is arguably the most demanding application in terms of glass stability. In terms of glass formulation, this requirement tends to be in contradiction with the need for low softening temperature, as discussed hereafter.

Glass stability and devitrification in the $\mathrm{Bi}_{2} \mathrm{O}_{3}-\mathrm{B}_{2} \mathrm{O}_{3}$ binary system, which is the basis for most of the commercial formulations, has been the object of several studies. ${ }^{110,317,318,326}$ Except the oldest study, ${ }^{110}$ they agree on a practical stability optimum near $45 \% \mathrm{BiO}_{1.5}$, in agreement with the break in the liquidus temperature (Figure 2), vs. falling $T_{g}$ (Figure 3); this somewhat lower optimum than Figure 2 would suggest lies in crystallisation of the metastable phase $\mathrm{BiBO}_{3} .{ }^{318}$

As discussed in section 3.2, small additions of other network formers and modifiers, as well as oxides such as $\mathrm{Fe}_{2} \mathrm{O}_{3}$ and lanthanides, hinder crystallisation; $\mathrm{ZnO}-\mathrm{Bi}_{2} \mathrm{O}_{3}-\mathrm{B}_{2} \mathrm{O}_{3}-\mathrm{SiO}_{2}$ compositions specified in the early Soviet patents (Table 7; B80, B82 and B89), reported there as non crystallising and containing no alkalis, provide a good starting basis for lowtemperature sealing glasses, and the overwhelming majority of the subsequent research and patent literature report very similar compositions.

Hasegawa et al., 313,314 in their patent applications, performed arguably the most extensive discussion - although very empirical and on a weight basis - of composition optimisation and stability in this system; the resulting restrictions, converted to a cation molar percentage basis, are given in Table 18 and discussed hereafter.

The indicated data are according the second application, ${ }^{314}$ which specifies a minimum amount of $\mathrm{Al}_{2} \mathrm{O}_{3}$ (recognising its beneficial effect on glass stability), and introduces a second, more restrictive composition range for low-temperature FPD sealing with fillers, which apparently requires even better stability against crystallisation. This can be due to the filler possibly promoting crystallisation and the sealing temperature lying in the range where crystallisation is most apt to occur; sealing processes that require stronger capillary flow or firing of conductors / resistor frits occur at higher temperatures where crystallisation is less likely, i.e. slightly below or even above the liquidus.

Overall, the requirements stated in Table 18 and corresponding compositions (Table 7-Hg) correlate fairly well with glass formation (section 3.2) and properties (3.1), as well as with our own preliminary refire stability experiments, performed with glass frits printed on alumina and glass and summarised in Figure 9. The main network former is $\mathrm{B}_{2} \mathrm{O}_{3}$, to minimise processing temperatures, with $\mathrm{SiO}_{2}$ and preferably some $\mathrm{Al}_{2} \mathrm{O}_{3}$ being added to improve stability.

The beneficial effects of mixing $\mathrm{B}_{2} \mathrm{O}_{3}, \mathrm{SiO}_{2}$ and $\mathrm{Al}_{2} \mathrm{O}_{3}$ are illustrated by comparing with other work where either $\mathrm{B}_{2} \mathrm{O}_{3}$ or $\mathrm{SiO}_{2}$ were used alone; ${ }^{311,355,433}$ densification is reported to be problematic, with a strong tendency to crystallisation. ${ }^{355,433}$ Crystallisation problems may also be inferred from a higher sealing temperature, in spite of a low filler volume fraction. ${ }^{311}$ In accordance with Table $18^{314}$, using a very low amount of $\mathrm{SiO}_{2}$ in $\mathrm{SrO}-\mathrm{ZnO}-\mathrm{Bi}_{2} \mathrm{O}_{3}-\mathrm{B}_{2} \mathrm{O}_{3}$ (Nch-01), is reported to yield a devitrified seal, albeit with enough prior flow to achieve successful densification. ${ }^{312}$ 
Table 18. Composition ranges and ratios specified for sealing glass stability. ${ }^{314}$

\begin{tabular}{|c|c|c|c|c|c|c|}
\hline \multirow{2}{*}{$\begin{array}{c}\text { Cation } \\
\mathrm{Zn}\end{array}$} & \multicolumn{3}{|c|}{$\begin{array}{l}\text { Limits "Magnetic head" } \\
\text { High flow, without fillers } \\
\text { [cation \%], low-high }\end{array}$} & \multicolumn{3}{|c|}{$\begin{array}{l}\text { Limits "FPD seal" } \\
\text { Low flow, with fillers } \\
\text { [cation \%], low-high }\end{array}$} \\
\hline & 7 & - & 29 & 16 & - & 28 \\
\hline $\mathrm{Bi}$ & 23 & - & 59 & 39 & - & 52 \\
\hline $\mathrm{B}$ & 13 & - & 29 & 15 & - & 32 \\
\hline $\mathrm{Si}$ & 1.3 & - & 22 & 2.4 & - & 9 \\
\hline $\mathrm{Al}$ & 0.2 & - & 4 & 0.2 & - & 4 \\
\hline $\mathrm{Zn} / \mathrm{B}$ ratio & 35 & - & 120 & 47 & - & 107 \\
\hline Al/Si ratio & 1 & - & 59 & 1 & - & 59 \\
\hline $\mathrm{Li}$ & 0.0 & - & 13 & 0.0 & - & 16 \\
\hline $\mathrm{Na}$ & 0.0 & - & 10 & 0.0 & - & 16 \\
\hline $\mathrm{K}$ & 0.0 & - & 9 & 0.0 & - & 6 \\
\hline $\mathrm{Li}+\mathrm{Na}+\mathrm{K}$ & 0.0 & - & 19 & 0.0 & - & 16 \\
\hline $\mathrm{Mg}$ & 0.0 & - & 15 & 0.0 & - & 7 \\
\hline $\mathrm{Ca}$ & 0.0 & - & 13 & 0.0 & - & 11 \\
\hline $\mathrm{Sr}$ & 0.0 & - & 10 & 0.0 & - & 6 \\
\hline $\mathrm{Ba}$ & 0.0 & - & 9 & 0.0 & - & 4 \\
\hline $\mathrm{Mg}+\mathrm{Ca}+\mathrm{Sr}+\mathrm{Ba}$ & 0.0 & - & 20 & 0.0 & - & 12 \\
\hline $\mathrm{Ln}, \mathrm{Ce}$ & 0.1 & - & 8 & 0.1 & - & 4 \\
\hline
\end{tabular}

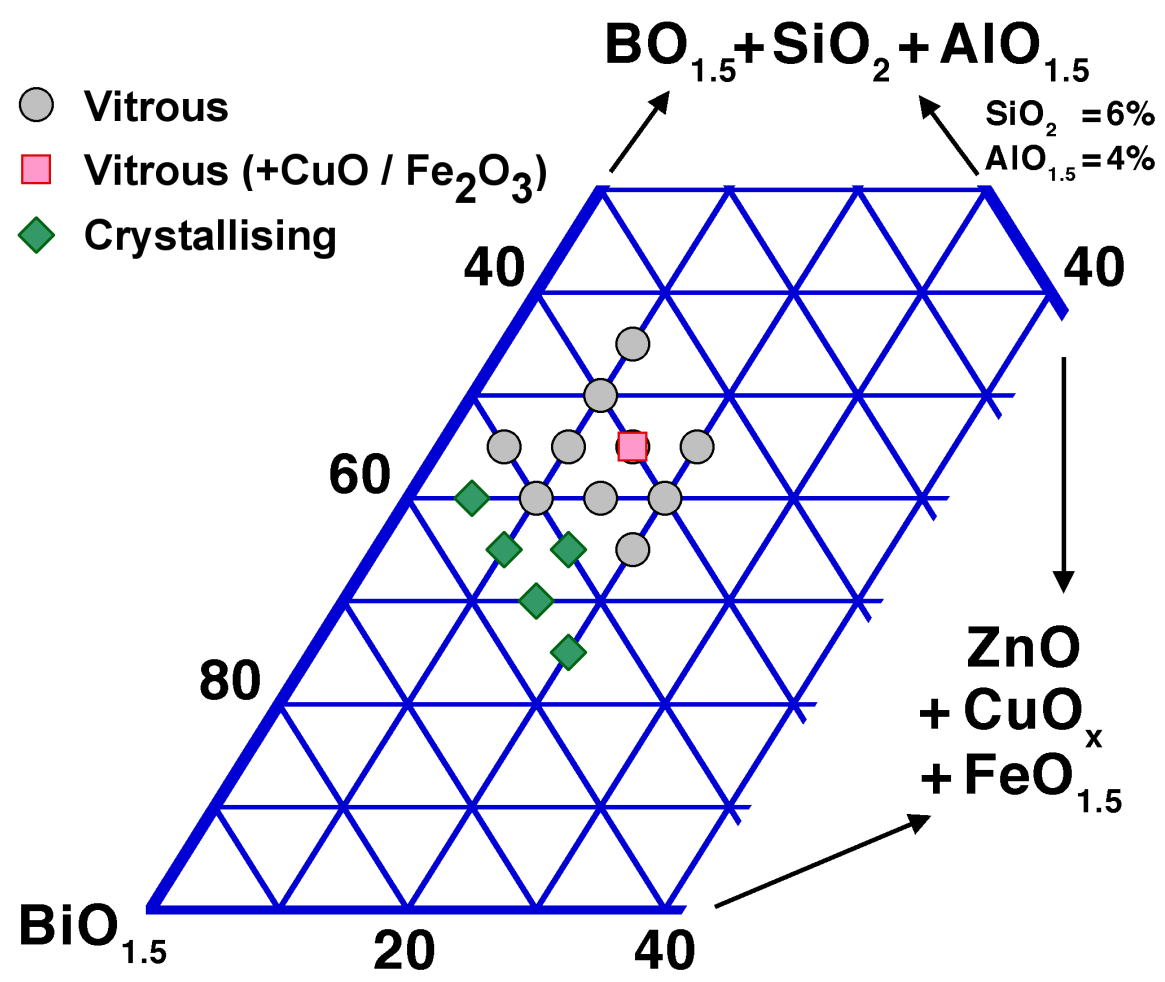

Figure 9. Results, in cation\%, of our experiments on stability of $\mathrm{Bi}_{2} \mathrm{O}_{3}$-based glasses in TF firing cycles (belt oven, $45 \mathrm{~min}$ total time with $10 \mathrm{~min}$ at peak, $400-700^{\circ} \mathrm{C}$ ). 
Stability is improved by low levels of $\mathrm{ZnO}$ and alkaline earth additions, and degraded by excessive amounts, in line with vitrification studies (see e.g. Figure 4) and other work. ${ }^{263}$ The stated maximum amounts of alkaline earths should be taken with caution, as they were added without regard to $\mathrm{ZnO}$; a more pertinent test would be to add them with corresponding reduction of $\mathrm{ZnO}$, i.e. keeping $\mathrm{Zn}+$ alkaline earths constant. Rare earths (Ln), including cerium, are stated to improve mechanical strength, an advantage compounded by $\mathrm{CeO}_{2}$ being a useful fining agent (section 3.4), and a low level of lanthanides providing stability vs. devitrification. ${ }^{275}$ One not mentioned compound is $\mathrm{Fe}_{2} \mathrm{O}_{3}$, which is reported, together with $\mathrm{CuO}_{y} / \mathrm{MnO}_{y}$, to be a useful alternative to $\mathrm{Al}_{2} \mathrm{O}_{3}$ against devitrification in modern very lowmelting lead-bearing sealing glasses; ${ }^{149,} 151,242$ interestingly, $\mathrm{Fe}_{2} \mathrm{O}_{3}$ seems to stabilise $\mathrm{Bi}_{2} \mathrm{O}_{3}$ based glasses as well. ${ }^{255}$ These effects are expected to strongly depend on composition, i.e. formed crystalline phase(s) according to phase diagram, i.e. borates for low-melting glasses. In higher-melting, essentially $\mathrm{Bi}_{2} \mathrm{O}_{3}-\mathrm{SiO}_{2}$ glasses, crystallisation of $\mathrm{Bi}_{2} \mathrm{SiO}_{5}$ has been found to be promoted by $\mathrm{Cr}_{2} \mathrm{O}_{3}$, but inhibited by $\mathrm{CuO}_{y}$ and $\mathrm{MnO}_{y}{ }^{301}$

Practical sealing examples, taken from the patent literature, ${ }^{149,} 242,311,314$ given in Table 19, illustrate the potential of the new Bi-based glasses (Hg-203/324 / Usu-5) for low-temperature sealing, well below the softening point of common float glass, and thus clearly demonstrates their industrial usefulness.

On the other hand, these examples also illustrate the remaining gap with the $\mathrm{Pb}$-bearing frits (LTS) for ultra low-temperature sealing of electronic and optical devices at temperatures compatible with some engineering polymers, e.g. glass fibre coatings, ${ }^{242}$ in spite of these compositions not containing any alkalis. However, further studies combining fluxing additives such as $\mathrm{F}^{-}, \mathrm{TeO}_{2}, \mathrm{~V}_{2} \mathrm{O}_{5}, \mathrm{Nb}_{2} \mathrm{O}_{5}$, and $\mathrm{MoO}_{3}$ with stabilising agents $\left(\mathrm{Ln}_{2} \mathrm{O}_{3}, \mathrm{Fe}_{2} \mathrm{O}_{3}\right.$, ...), i.e. optimisation similar to that of the lead-bearing frits, should yield further progress in lowering achievable sealing temperatures.

\subsection{Overglazing / enamelling}

Low-melting glassy layers (overglazes, or enamels) find a large palette of applications in electronics, ${ }^{291}, 302,307,321$ displays, ${ }^{181}$ automotive / $\operatorname{architectural} /$ container glass ${ }^{33,47,432}$ and

cookware / dishware / chinaware, ${ }^{47,56}$ as protective and decorative layers. Examples and properties are given in Table 20.

In TF electronics, overglazes protect resistors against humidity, and Ag-rich conductors against electrochemical migration, thereby improving circuit reliability. ${ }^{63,434}$ Other functions useful during processing are solder masking and protection of resistors against acid electrochemical plating baths. As for sealing, conductors are absent or lie side-by-side (Figure 8B); excellent electrical insulation characteristics are therefore in most cases not necessary, and minor alkali additions are usually allowed.

The choice of a TF overglaze is a balance between limiting the shift in resistor characteristics and guaranteeing a sufficient level of protection. Both standard (e.g. ESL 4771P,

Table 5) and acid-resistant (such as Her CL90-8325, roughly equivalent to lead-bearing ESL-481) lead-free overglazes are now available from most thick-film materials suppliers. For very low required processing temperatures, one may use the sealing glasses discussed in the previous section, adding fillers to increase strength / abrasion resistance or to match the CTE to that of the substrate, or slightly higher-firing glasses. ${ }^{291}$ 
Table 19. Composite sealing glasses (compositions: see Table 7).

\begin{tabular}{|c|c|c|c|c|c|c|}
\hline Glass & \multicolumn{2}{|c|}{ Filler \& vol.\% } & $\mathbf{T}_{\mathbf{s}}{ }^{*}$ & $\mathbf{T}_{\text {seal }}{ }^{*}$ & CTE $_{\text {glass }}$ & $\begin{array}{r}\text { CTE }_{\text {seal }} \\
\end{array}$ \\
\hline $\mathrm{Hg}-203^{314}$ & Cordierite & $62 \%(40)^{\dagger \dagger}$ & 410 & 460 & 10.8 & 7.2 \\
\hline $\mathrm{Hg}-324^{314}$ & $\mathrm{ZrSiO}_{4}$ & $58 \%(50)^{\dagger \dagger}$ & 422 & 472 & 10.4 & 6.9 \\
\hline Usu-5 $5^{311}$ & $\mathrm{ZrSiO}_{4}$ & $32 \%^{\dagger}$ & - & 500 & (11) & 7.9 \\
\hline LTS- $1^{149}$ & $\begin{array}{l}\text { Cordierite } \\
\mathrm{ZrSiO}_{4}\end{array}$ & $\begin{array}{l}30 \% \\
10 \%\end{array}$ & $297^{\#}$ & 360 & 13.3 & 6.4 \\
\hline $\mathrm{LTS}^{2} 2^{242}$ & $\mathrm{PbTiO}_{3}$ & $18 \%$ & $235 \#$ & $<350$ & (15) & \\
\hline
\end{tabular}

Notes. $\dagger$ Calculated assuming glass density $\approx 61500 \mathrm{~kg} / \mathrm{m}^{3}-\dagger \dagger$ values for $\mathrm{Hg}-203 / 324$ (examples $6 \mathrm{~A}$ and $6 \mathrm{D}$ ) in original work dubious (too high) - confusion with volume faction $(40 / 50 \%)$ likely. ${ }^{*} \mathrm{~T}_{\mathrm{S}}=$ Littleton softening point, at which viscosity $\eta$ is $10^{6.6} \mathrm{~Pa} \mathrm{~s}$; $\mathrm{T}_{\text {seal }}=$ sealing temperature. \# LTS-1 estimated as $\mathrm{T}_{\mathrm{g}}+50 \mathrm{~K}$; LTS-2 as flow point-30 K.

Table 20. Overglaze / enamel / dielectric properties (glass compositions: see Table 7).

\begin{tabular}{lcl}
\hline Glass & Firing temp. $\left[{ }^{\circ} \mathrm{C}\right]$ & Description \\
\hline $\mathrm{Hy}-29^{321}$ & 650 & Acid-resistant TFR overglaze \\
\hline Don- $01 / 04^{307}$ & 620 & As above; low TFR drift \\
\hline Fri-1 $1^{48}$ & 700 & Forms $\mathrm{Zn}_{2} \mathrm{SiO}_{4} \& \mathrm{Bi}_{4}\left(\mathrm{SiO}_{4}\right)_{3}$, poor acid durability \\
\cline { 2 - 3 } Fri-2 & As above, $+\mathrm{Bi}_{4} \mathrm{Ti}_{3} \mathrm{O}_{12} ;$ durability limited by glass \\
\hline $\mathrm{Lvx}^{56}$ & 700 & Enamel for aluminium alloys \\
\hline $\mathrm{L}-\mathrm{Bi} 12^{323}$ & 560 & Filled with $\approx 40 \%$ vol. $\mathrm{Al}_{2} \mathrm{O}_{3} / \mathrm{SrTiO}_{3}$, poor refire stability \\
\hline
\end{tabular}

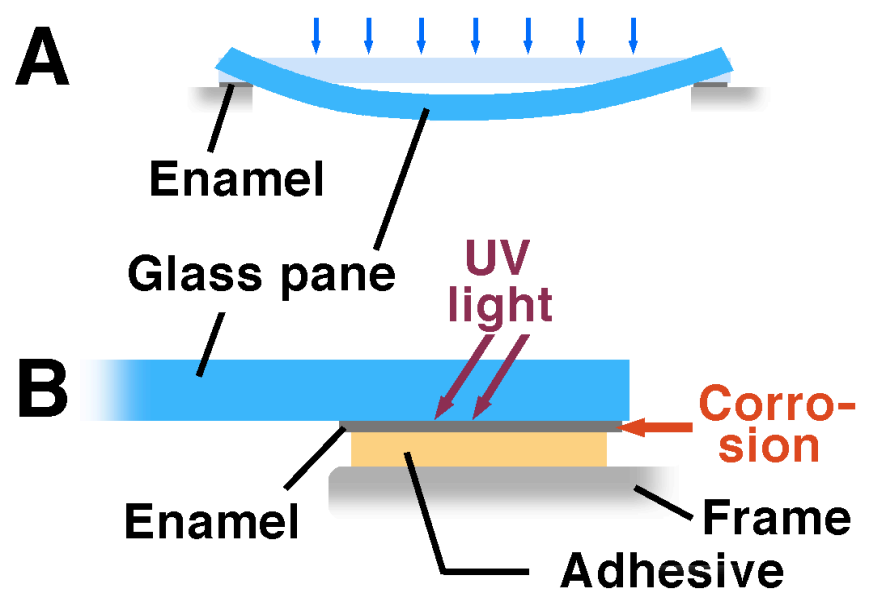

Figure 10. Application of enamel to automotive glass, as (A) anti-stick layer during forming and (B) adhesive protection layer. Redrawn from Sakoske. ${ }^{47}$ 
As for the older lead-bearing glasses, acid-resistant types require a higher firing temperature, ca. $600^{\circ} \mathrm{C}$, than standard ones. However, extensive publications on the chemistry and properties of Bi-based TFR overglazes are still lacking, although some examples are available in the patent literature (Table $20, \mathrm{Hy}-29^{321} \&$ Don- $01 / 04^{307}$ for the $\approx 600^{\circ} \mathrm{C}$-firing types); information may be garnered, for the low-firing $\left(\leq 550^{\circ} \mathrm{C}\right)$ type, from sealing glasses. ${ }^{289}, 290,293$, 313,314

A related application is the overglazing of displays (FPDs), where, besides providing suitable protection, the overglaze must avoid excessive degradation of the transparent conductor, usually indium tin oxide (ITO) on the glass. This is achieved using low-firing glasses similar to the sealing types, with a low level of $\mathrm{In}_{2} \mathrm{O}_{3}, \mathrm{SnO}_{2}$ and $\mathrm{SbO}_{y}$ additives. ${ }^{297,308}$

Low-firing TF circuits (e.g. for FPDs) mostly use pure or almost pure Ag conductors, as Pd tends to oxidise in the intermediate firing range, ${ }^{64}$ which raises the issue of staining by indiffusion of $\mathrm{Ag}^{+}$and probable reprecipitation of $\mathrm{Ag}^{0}$. This is prevented by $\mathrm{Cu}^{308,435}$ and $\mathrm{Cr}^{306}$ additions, presumably through oxidoreduction mechanisms.

Compared to consumer electronics, automotive and architectural enamels are exposed to much more severe outdoors environments, such as acid rain. ${ }^{33,47,48}$ In a way typical of the high-volume cost-sensitive automotive industry, single window-rim dark enamel coating fulfils multiple roles, as illustrated in Figure 10: A) anti-stick agent during forming of the panel, and B) hiding of the adhesive and its protection against ultraviolet (UV) light. Moreover, to optimise costs, the enamel must fire and achieve anti-stick properties reliably during the heating step required for forming of the window pane $\left(650-700^{\circ} \mathrm{C}^{47,436}\right)$, and be sufficiently resistant to atmospheric attack to avoid requiring extra protective layers.

Such enamels have recently undergone extensive development, as attested in the patent literature. ${ }^{298,299,301,432,436-439}$ Firing temperatures are in the $600-675^{\circ} \mathrm{C}$ range suitable for glass processing. First compositions were mainly glassy, relying on pigments to provide anti-stick properties, but have been replaced by crystallising compositions optimised to achieve the best chemical durability. In this respect, the trend has gone from $\mathrm{Zn}$ borates ${ }^{437}$ to $\mathrm{Zn} / \mathrm{Bi}$ silicates ${ }^{438-}$ 440 and finally to mixed $\mathrm{Bi}\left(\mathrm{Bi}_{4} \mathrm{Ti}_{3} \mathrm{O}_{12}, \mathrm{Bi}_{2} \mathrm{Ti}_{2} \mathrm{O}_{7}, \mathrm{Bi}_{2} \mathrm{Ti}_{3} \mathrm{O}_{9}\right) \&$ other $(\mathrm{Zn}, \mathrm{V}-\mathrm{Bi})$ titanates, ${ }^{302,436}$ which are claimed to exhibit better chemical resistance to acid attack. This is generally in accordance with the investigations of Fredericci et al., ${ }^{48}$ who report increasing acid resistance going from $\mathrm{Zn}$ silicate to $\mathrm{Bi}$ silicate to $\mathrm{Bi}$ titanate phases, and the facile crystallisation of titanate phases. ${ }^{48,363}$ Other compounds with "acidic" oxides such as $\mathrm{V}_{2} \mathrm{O}_{5}, \mathrm{Nb}_{2} \mathrm{O}_{5}, \mathrm{Ta}_{2} \mathrm{O}_{5}$, $\mathrm{MoO}_{3}$ and $\mathrm{WO}_{3}$, alone or mixed, ${ }^{364}$ may probably have similar beneficial effects on acid resistance, but the composition must also be tuned in order to ensure sufficient durability of the remaining glass phase.

When coating glass or ceramics, an important issue is the degradation of the strength of the glass substrate by application of the enamel. ${ }^{47,441}$ This is not specific to Bi-based glasses, as similar effects have also been observed by our group on ceramic TF circuits with "classical" lead-bearing materials. ${ }^{442}$ The implications are significant, as automotive windshields play a structurally important role in cars, and TF electronics are used in high-reliability, safetycritical applications.

\subsection{Insulating dielectrics}

As reliable crystallisable lead-free dielectrics are readily available for standard $850^{\circ} \mathrm{C}$ firing conditions, ${ }^{163}$ Bi-based glasses are mainly applied to low-firing insulating layers for circuitry on glass (FPDs / PDPs) ${ }^{181,308,431}$ or metal. $^{71,323}$ Typical configurations are multilayer circuits and crossovers (Figure 8C), as well as the deposition of complete circuits on metal (D). 
Dielectrics may be formulated essentially the same way as filled sealing glasses, with the difference that some sort of "stabilisation" is desirable. Otherwise, the dielectric (e.g. L-Bi12, Table 20) tends to reflow upon subsequent firing of conductors and resistors. Stabilisation may be achieved by crystallisation (spontaneous or filler-nucleated) ${ }^{312}$ and/or by chemical reaction with the filler, as successfully experimented with PbO-bearing glasses. ${ }^{161,162} \mathrm{Bi}_{2} \mathrm{O}_{3}$ should react similarly, with the "acidic" oxides mentioned in the previous section; tuning the reactivity may be achieved by varying the glass composition, as well as the chemistry, amount and particle size of reactive filler.

\subsection{Dielectrics on metal substrates}

Commercial thick-film dielectrics / enamels for firing onto stainless steel exist (see

Table 5), but, as the porcelain-enamelled steel they replace, they require high processing temperatures unsuitable for sensors or application to substrates such as titanium (limited by oxidation) or aluminium (limited by melting), ${ }^{68,71}$ and low-firing dielectrics must be used.

However, dielectrics on metal face one important issue stemming from the reducing conditions (section 3.4) at the substrate-dielectric interface; to ensure good adhesion, the formation of soft and low-melting metallic $\mathrm{Bi}$ and $\mathrm{Pb}$ should be avoided. Pre-oxidation of the metal is not always possible or useful due to reasons such as manufacturing process requirements, insufficient oxide adhesion or thickness. Moreover additional reducing conditions may be generated, on alloys forming $\mathrm{Cr}_{2} \mathrm{O}_{3}$ scales such as stainless steels, by chromate formation $\left(\mathrm{Cr}^{3+\rightarrow 6+}\right)$ with glass components such $\mathrm{BaO}, \mathrm{PbO}$ and $\mathrm{Bi}_{2} \mathrm{O}_{3},{ }^{443}, 444$ although $\mathrm{Cr}$ may also remain as $\mathrm{Cr}^{3+}$ in the glass. ${ }^{373}$ Therefore, a generally applicable approach on metallic substrates consists in including significant amounts of transition metals that may be partially reduced in the glass $\left(\mathrm{Fe}^{3+\rightarrow 2+}, \mathrm{Mn}^{4+\rightarrow 3+\rightarrow 2+}, \mathrm{Co}^{3+\rightarrow 2+}, \mathrm{Cu}^{2+\rightarrow 1+}\right)$, and that are moreover not deleterious when fully reduced to metal; Co is in fact found in dielectrics for steel substrates (

Table 5). As the situation is very similar to $\mathrm{PbO}$, it is surmised that our previous experiments with $\mathrm{Pb}$-based glasses, where $\mathrm{Fe}_{2} \mathrm{O}_{3}$ additions were successfully applied, ${ }^{68,71}$ may be extended to Bi-based ones.

It must be mentioned no adhesion problems were encountered on $\mathrm{Al}$ alloys, ${ }^{445}$ in spite of the very strong reducing power of $\mathrm{Al}$; it is surmised that formation of $\mathrm{Al}_{2} \mathrm{O}_{3}$ rapidly results in the effective stoppage of oxygen diffusion, and hence limited interaction with the substrate, a hypothesis supported by the absence of oxidoreduction buffers in commercial enamels for $\mathrm{Al}^{56}$

The high CTE some metals, such as austenitic stainless steel $\left(17 \mathrm{ppm} \mathrm{K}^{-1}\right)$ and aluminium alloys (23) constitutes an additional issue, causing warping of thin substrates and excessive stress build-up in the dielectric. This may be corrected by suitable high-expansion fillers such as quartz, cristobalite, $\mathrm{CaF}_{2}$ and $\mathrm{AlPO}_{4}$, using chemical particle coating techniques if chemical reactions must be limited. In contrast, ferritic low-alloy or stainless steel $\left(\approx 11 \mathrm{ppm} \mathrm{K}^{-1}\right)$ and Ti alloys (8-10) are reasonably well matched with low-melting Bi-based frits $(8-11)$.

As a final note, commercial lead- and alkali-free bilayer low-firing dielectrics on aluminium substrates have recently become available, ${ }^{446}$ but no detailed studies on their composition has been carried out to date. 


\subsection{Metallisations \& thick-film conductors}

Metallisations and conductors for electroceramic components such as resistors, capacitors voltage limiters, for solar cells, for automotive window heaters and thick-film conductors fundamentally share the same technology, i.e. the starting material is a finely-divided conductor powder such as $\mathrm{Ag}, \mathrm{Ag}: \mathrm{Pd}, \mathrm{Au}, \mathrm{Cu}$, with oxide and/or glass frit additive that promote densification and bonding to the substrate. ${ }^{21,60,63,64,447-451}$ While traditional lead borosilicate frits are widely used, application of Bi-based frits in conductors is hardly new, with the $1^{\text {st }}$ patent going back to $1945,{ }^{283}$ and such conductors being widely in use by the early 1970 's ${ }^{88,449,452}$ - see also

Table 5. Mixed $\mathrm{PbO}-\mathrm{Bi}_{2} \mathrm{O}_{3}-\mathrm{B}_{2} \mathrm{O}_{3}-\mathrm{SiO}_{2}$ glass frits have also been used, and $\mathrm{Bi}_{2} \mathrm{O}_{3}$ is also added in its own right, without nominally being part of a glass frit, ${ }^{158,159,288,310,452-457}$ in order to impart good adhesion by reacting with the substrate and potentially also with the metals, as well as for promoting liquation in fritless conductors. ${ }^{158,457,458}$ Its reactivity with $96 \%-\mathrm{Al}_{2} \mathrm{O}_{3}$ $\left(+3.8 \% \mathrm{SiO}_{2} \& 0.2 \% \mathrm{CaO}\right.$; mass $\left.\%\right), 99.9 \%-\mathrm{Al}_{2} \mathrm{O}_{3}$ and $\mathrm{BeO}$ has been extensively studied. ${ }^{459}$ $\mathrm{Bi}_{2} \mathrm{O}_{3}$ does reacts with $\mathrm{Al}_{2} \mathrm{O}_{3}$, but reaction with the $\mathrm{SiO}_{2}$ contained in the glass phase of $96 \%$ $\mathrm{Al}_{2} \mathrm{O}_{3}$ is dominant below $850^{\circ} \mathrm{C}$. Finally, $\mathrm{Bi}_{2} \mathrm{O}_{3}$ (and $\mathrm{PbO}$ ) may also be added to conductor metallisations for electroceramics that contain these elements, in order to control the chemical interactions. ${ }^{451}$ The technical importance of integrating elements in the frit or adding them separately is not clear, i.e. avoidance of patent infringement may also play an important role...

The rather low affinity to oxygen of bismuth makes it easily reduced, at least partially, during firing or soldering. It is believed that partial reduction of $\mathrm{Bi}$ and $\mathrm{Cu}$ and partition between noble metal and oxides favours the formation of bridging bonds and thereby good adhesion. ${ }^{88}$, 159,251 Solderability is of course also favourably impacted, but aged adhesion of solder pads can be affected if reduction of bismuth by tin in solder proceeds in service, ${ }^{64,449}$ a problem that may be mitigated by incorporation of $\mathrm{Bi}_{2} \mathrm{O}_{3}$ into other oxides or glass frit (initially or during firing) or by adding oxides that act as barriers against this reaction. ${ }^{160,456} \mathrm{Bi}_{2} \mathrm{O}_{3}$ may also lead to formation of lossy semiconducting interfacial reaction products at electrocomponent interfaces ${ }^{310}$ and, in popular Ag-Pd metallisations, reinforce the problematic oxidation of $\mathrm{Pd}$ to $\mathrm{PdO}$ at intermediate temperatures by formation of $\mathrm{Bi}_{2} \mathrm{PdO}_{4}$, retarding Pd reduction at high temperatures. ${ }^{64,460}$

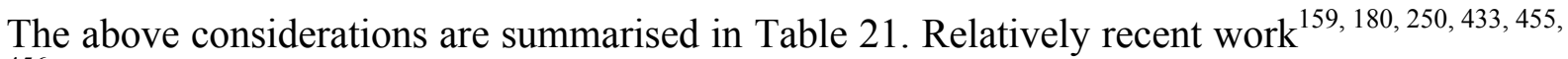
456 details both fritless and fritted (Table 7, Hw-00) Bi-containing Pb-free silver-based conductors, and such conductors have recently become much more widely available from thick-film materials suppliers.

The case of solar cell front-side Ag metallisations is rather special: the traditionally $\mathrm{PbO}-$ bearing glass frit must dissolve the antireflective layer (normally $\mathrm{SiN}_{y}$ ) and ideally create a good ohmic contact with the underlying n-type silicon emitter ${ }^{43,50}$ in a highly non-equilibrium dissolution-oxidoreduction-precipitation process. The overall reaction sequence has been shown to involve dissolution of Ag into the glass and reduction by Si to form crystallites, but the exact conduction mechanism - some direct connections or only tunnelling in a similar fashion to TFRs (next section) and the role of $\mathrm{PbO}$ in the frit are still somewhat elusive ${ }^{43}$. Nevertheless, successful substitution of $\mathrm{PbO}$ by $\mathrm{Bi}_{2} \mathrm{O}_{3}$ has been demonstrated recently, with presence of $\mathrm{Ag}$ ions in the glass enhanced by prior incorporation into the frit as $\mathrm{Ag}_{2} \mathrm{O}$ (Jeo-1, or Jeo- 1 ' if $\mathrm{Al}_{2} \mathrm{O}_{3}$ and $\mathrm{B}_{2} \mathrm{O}_{3}$ mistakenly inverted in the paper, as is likely) ${ }^{53}$ or by firing in pure oxygen. ${ }^{52}$ These results allow removal of lead from what has become a high-volume industry. 
Table 21. Advantages \& issues of $B i$ in conductors and component metallisations.

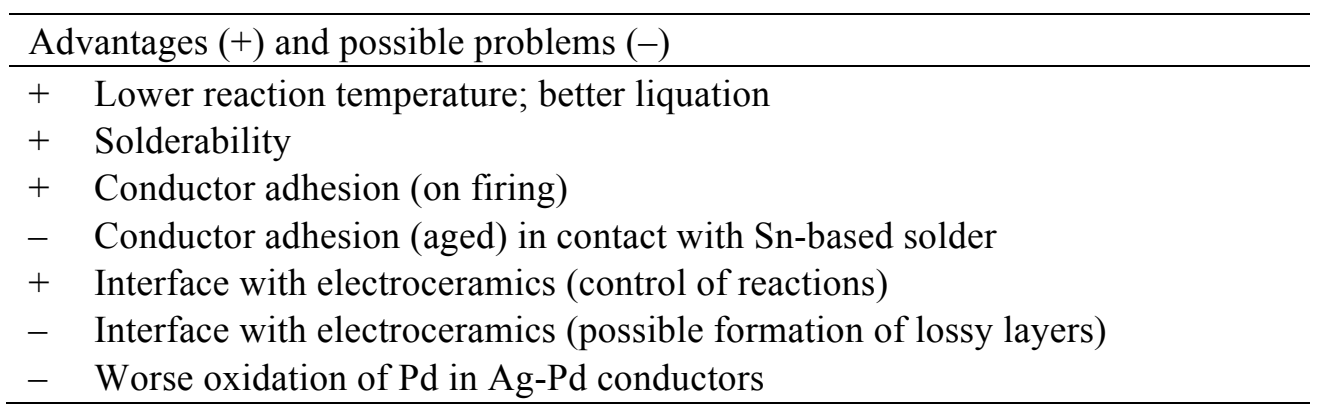

\subsection{Glasses for thick-film resistors}

Current "cermet" thick-film resistor (TFR) compositions consist of a granular conductive phase dispersed in a glassy insulating matrix, ${ }^{59,61,62,461-465}$ with additives to control the electrical properties; ${ }^{466,467}$ conduction occurs by percolation through the conductive grain network, with intergrain transport through a nm-thin glass film, thought to occur by tunnelling, essentially accounting for the overall resistivity (Figure 11). ${ }^{84}, 463,468-474$ In classical TFR series, the conductive phase is mainly ruthenium oxide $\left(\mathrm{RuO}_{2}\right)$ and/or its pyrochlore compounds with $\mathrm{PbO}$ and $\mathrm{Bi}_{2} \mathrm{O}_{3}$, lead and bismuth ruthenate $\left(\mathrm{Pb}_{2} \mathrm{Ru}_{2} \mathrm{O}_{7-y}\right.$ and $\mathrm{Bi}_{2} \mathrm{Ru}_{2} \mathrm{O}_{7}$ ), and the glassy matrix is a high-lead lead borosilicate glass (Figure 12). ${ }^{59,}{ }^{62,475}$ Ruthenates give a higher resistivity than $\mathrm{RuO}_{2},{ }^{423}$ and the composition of the glass also has a strong effect, both on the stability of ruthenates vs. $\mathrm{RuO}_{2}$ and directly on the resistivity. ${ }^{464,476}$ Alternative conductive phases for resistors can be based on $\mathrm{IrO}_{2}$ (properties similar to $\mathrm{RuO}_{2}$, more expensive, $)^{477,478}$ and compounds with $\mathrm{CaO}, \mathrm{SrO}$ and $\mathrm{BaO}$, which have the perovskite structure, are also possible. ${ }^{155}$ The synthesis and properties of $\mathrm{RuO}_{2}, \mathrm{IrO}_{2}$, their pyrochlore compounds and similar substances have been extensively studied. ${ }^{155,203,479-489}$ They belong to the class of electrically conductive oxides, which have been (very) extensively reviewed. ${ }^{490}$

Such a complex resistor chemistry suggests possible particle-glass chemical reactions, as $\mathrm{Bi}_{2} \mathrm{O}_{3}$ and $\mathrm{PbO}$ may be both in the glass and in the particles, and the configuration before firing may not be the equilibrium one. This is common in commercial systems, which frequently combine $(\mathrm{Pb}, \mathrm{Bi})_{2} \mathrm{Ru}_{2} \mathrm{O}_{7-y}$ as the (initial) conductive phase dispersed in lead borosilicate glass, giving rise to exchange of $\mathrm{Bi}_{2} \mathrm{O}_{3}$ and $\mathrm{PbO}$ between the glass and the conducting phase as well as decomposition reactions. ${ }^{61,62,465,491,492}$ One may write the following main chemical equilibria:

$$
\begin{aligned}
& 2\left(\mathrm{BiO}_{1.5}, \mathrm{PbO}\right)[\mathrm{g}]+2 \mathrm{RuO}_{2}[\mathrm{r}] \leftrightarrow(\mathrm{Bi}, \mathrm{Pb})_{2} \mathrm{Ru}_{2} \mathrm{O}_{7-y}[\mathrm{p}] \\
& \mathrm{BiO}_{1.5}[\mathrm{p}]+\mathrm{PbO}[\mathrm{g}] \leftrightarrow \mathrm{BiO}_{1.5}[\mathrm{~g}]+\mathrm{PbO}[\mathrm{p}] \\
& \mathrm{RuO}_{2}[\mathrm{r}] \leftrightarrow \mathrm{RuO}_{2}[\mathrm{~g}] \\
& (\mathrm{Bi}, \mathrm{Pb})_{2} \mathrm{Ru}_{2} \mathrm{O}_{7-y}[\mathrm{p}] \leftrightarrow 2\left(\mathrm{BiO}_{1.5}, \mathrm{PbO}\right)[\mathrm{g}]+2 \mathrm{RuO}_{2}[\mathrm{~g}]
\end{aligned}
$$

where: $[\mathrm{g}]$ - glass phase

[r] - conductive particles: rutile $\mathrm{RuO}_{2}\left(\right.$ or $\left.\mathrm{IrO}_{2}\right)$ phase

[p] - conductive particles: pyrochlore ruthenate (or iridate) phase 
Equation (1) relates to the equilibrium between the pyrochlore ruthenate phase and the simple rutile oxide, and (2) describes the equilibrium composition of the pyrochlore phase relative to that of the glass; (3) and (4) relate to dissolution into / precipitation from the glass, which are quantitatively small due to the low solubility of $\mathrm{RuO}_{2}$ in the glass, ${ }^{493,494}$ but may nevertheless play an important role in the electrical properties. ${ }^{495}$ Reactions of type (1) and (2) have indeed been observed experimentally, ${ }^{61,62,465,491}$ and a detailed study, for PbO only, established lead ruthenate was stable / formed only at moderate temperatures in glasses with lead concentrations much higher than that used in commercial systems; ${ }^{464}$ this was confirmed in our studies on model $\mathrm{RuO}_{2}$-glass TFRs. ${ }^{85,496}$ Therefore, most ruthenate-based formulations are not at thermodynamic equilibrium during firing. However, even in model systems where the conducting phase is thermodynamically stable (in practice, those formulated using $\mathrm{RuO}_{2}$ ), the glass composition strongly influences the resistivity. ${ }^{476,496}$

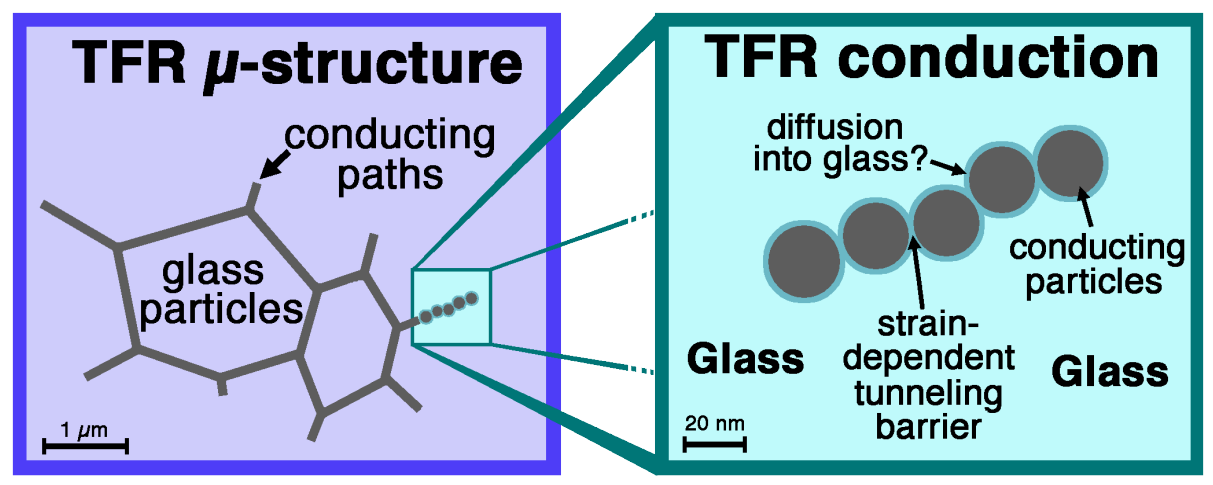

Figure 11. Microstructure and conduction mechanism of TFRs. ${ }^{1}$

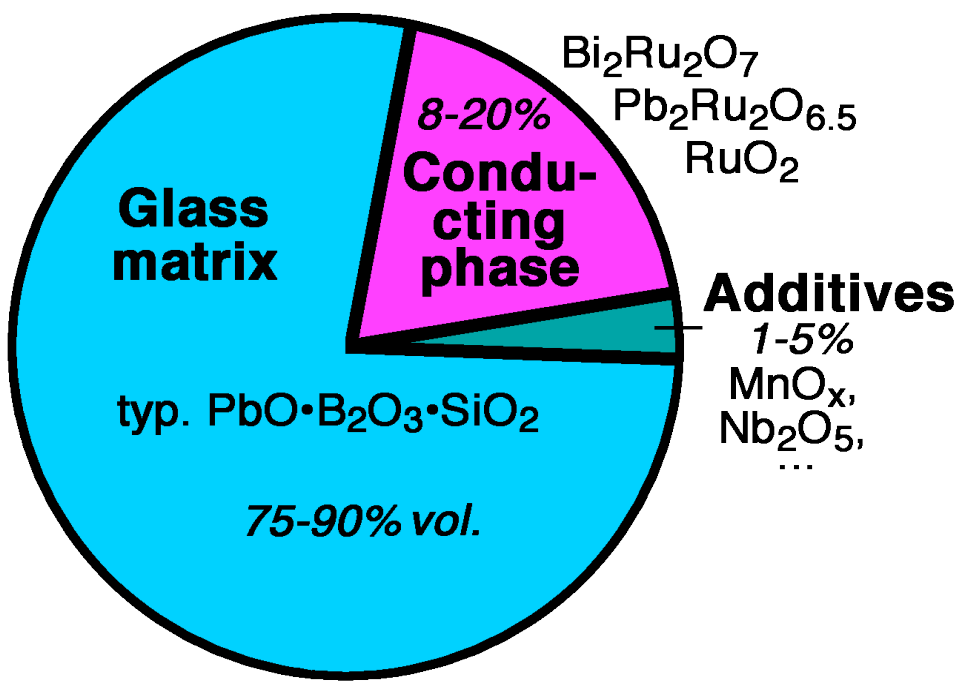

Figure 12. Typical composition (without temporary vehicle / binder) of thick-film resistors with lead borosilicate glass matrix. ${ }^{1}$ 
It must be additionally noted that the oxygen stoichiometry of $\mathrm{Pb}_{2} \mathrm{Ru}_{2} \mathrm{O}_{7-y}$ is reported to be $x=0.5,{ }^{483,}{ }^{484}$ which implies an average valence of +2.5 for $\mathrm{Pb}$ (or +4.5 for $\mathrm{Ru}$ ) in this compound. This adds a further complication, as formation / decomposition of lead ruthenate may involve a change of the oxidation state of $\mathrm{Pb}$, requiring exchange of oxygen with the firing atmosphere, an implication supported by results of TFR annealing studies in different atmospheres. ${ }^{497,}{ }^{498} \mathrm{On}$ the other hand, $\mathrm{Bi}$ and $\mathrm{Ru}$ essentially have the same valence in $\mathrm{Bi}_{2} \mathrm{Ru}_{2} \mathrm{O}_{7}$ as in the individual oxides $\mathrm{Bi}_{2} \mathrm{O}_{3}$ and $\mathrm{RuO}_{2}$; while $\mathrm{Bi}_{2} \mathrm{Ru}_{2} \mathrm{O}_{7}$ transforms at low temperatures to $\mathrm{Bi}_{3} \mathrm{Ru}_{3} \mathrm{O}_{11}$, ${ }^{460,499}$ formally linked with a slight oxidation, this transformation is apparently not observed in thick-film resistors, and does not involve a change of the $\mathrm{Bi}: \mathrm{Ru}$ stoichiometry $\left(\mathrm{Bi}_{2} \mathrm{Ru}_{2} \mathrm{O}_{7}\right.$ made by high-temperature synthesis is actually reported to be slightly nonstoichiometric, $\mathrm{Bi}_{2} \mathrm{Ru}_{2} \mathrm{O}_{6.9}$ or $\mathrm{Bi}_{1.9} \mathrm{Ru}_{2} \mathrm{O}_{6.9}$ - see supplement 13 - but this does not necessarily apply to "resistor-grade" nanopowders calcined at lower temperatures, ${ }^{483,488}$ whose stoichiometry would require further study).

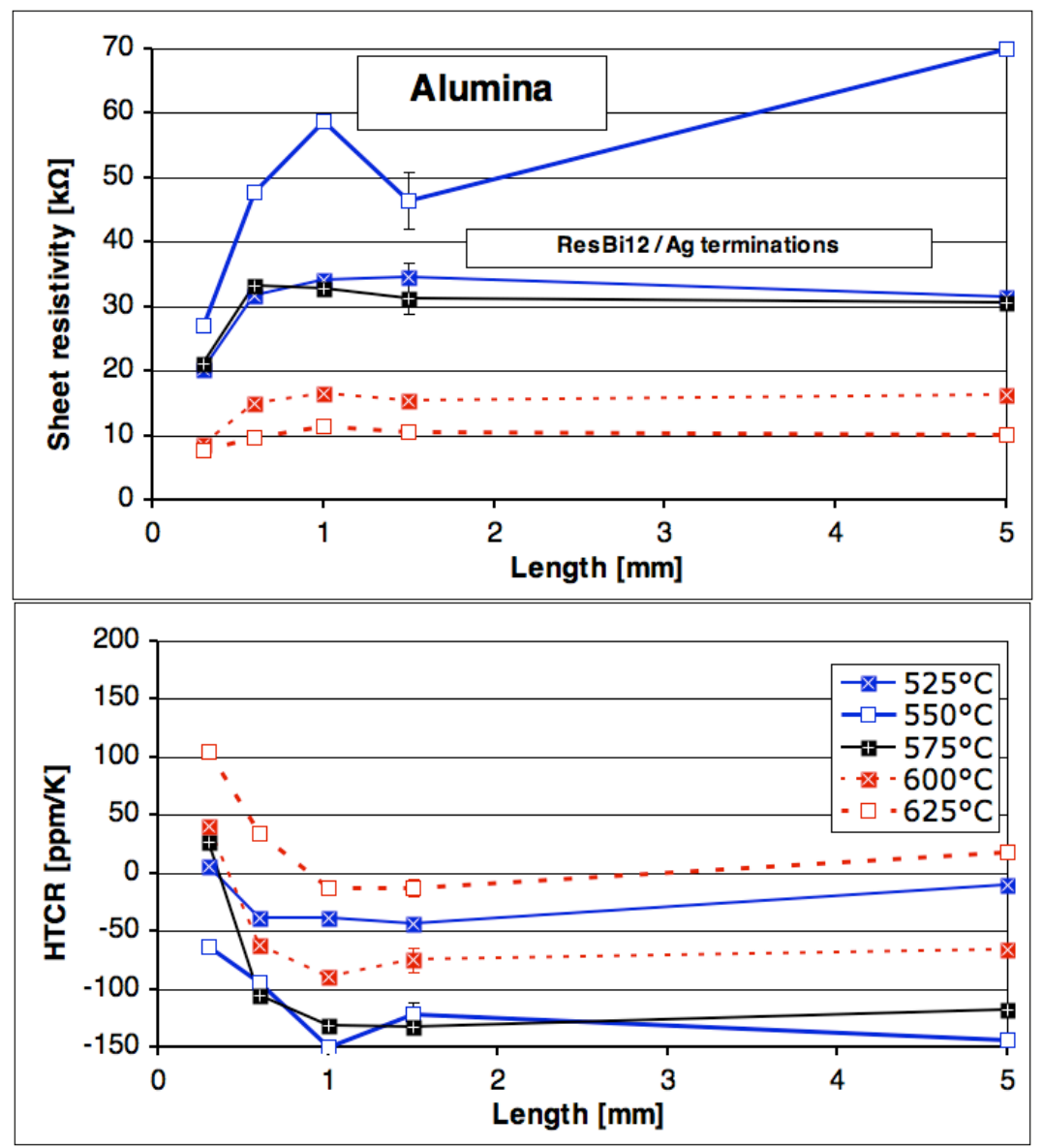

Figure 13. Sheet resistivity at $25^{\circ} \mathrm{C}$ and temperature coefficient $\left(H T C R, 25 \ldots 100^{\circ} \mathrm{C}\right)$, vs. length and firing temperature, of experimental TFRs fired on $\mathrm{Al}_{2} \mathrm{O}_{3}$ with $\mathrm{Ag}$ terminations. ${ }^{1}$ 
Therefore, it would seem logical to use a Bi-based glass in order to enhance resistor stability to firing, given the otherwise similar properties to $\mathrm{Pb}$-based glasses. This would also lessen the property changes that classical resistors formulated with $\mathrm{Pb}$-based frits encounter when fired with Bi-containing terminations. ${ }^{79,500}$ Therefore, it is not surprising that several such compositions have been patented ${ }^{251}$ (Table $7, \mathrm{Hm}$ ). Nevertheless, making the switch is not trivial, given the intricacies of TFR chemistry. Recently, first encouraging results - some of which by our group - have been published on lead-free TFRs with bismuth-based glasses and $\mathrm{RuO}_{2}$ conducting particles, ${ }^{1,70,322,323}$ for both standard $850^{\circ} \mathrm{C}^{251,322}$ and relatively low (ca. $600^{\circ} \mathrm{C}$ ) firing temperatures ${ }^{1,70,323}$ (see also Table 7, Hm/Hy/L-Bi12). The former is useful for application as standard thick-film resistors, while the latter may be used for low-firing compositions suitable for firing onto glass or high-strength temperature-sensitive metallic alloys to fabricate high-performance force and pressure sensors. ${ }^{1,68,69,71}$ An example of our results is given in Figure 13, for resistors consisting of LPM-Bi12 glass with $11 \%$ by mass of $\mathrm{RuO}_{2}(\approx 9 \%$ volume fraction) without additives. The results are very encouraging, featuring reproducible properties at firing temperature $\geq 550^{\circ} \mathrm{C}$ and moderate, normal termination effects, i.e. without the increase of resistivity at the terminations ${ }^{77,79}$ seen with the equivalent lead-bearing systems. ${ }^{69}$

Several aspects must be studied carefully for $\mathrm{Bi}_{2} \mathrm{O}_{3}$-based glasses to become a standard matrix for TFRs. First, thermodynamic properties of $\mathrm{RuO}_{2}, \mathrm{Bi}_{2} \mathrm{Ru}_{2} \mathrm{O}_{7}$ and related compounds in regard to Bi-based glasses must be known, especially the solubility of $\mathrm{RuO}_{2}$ in glass and the equilibrium between oxide and ruthenate, as was investigated in the lead-based systems.

Additionally, as oxides of transition metals such as $\mathrm{Ti}, \mathrm{Zr}, \mathrm{Nb}, \mathrm{Mn}, \mathrm{Fe}, \mathrm{Cu}$ and $\mathrm{Zn}$ are often added to control the temperature coefficient of resistance (TCR), it is important to know their possible interactions with $\mathrm{Bi}_{2} \mathrm{O}_{3}$ and $\mathrm{RuO}_{2}$. This has been the object of several studies, in pure oxide form, for $\mathrm{ZnO},{ }^{501} \mathrm{TiO}_{2},{ }^{502}, \mathrm{CuO},{ }^{503}$ and NiO. ${ }^{504}$ The $\mathrm{Bi}_{2} \mathrm{Ru}_{2} \mathrm{O}_{7}$ phase has been shown to be able to incorporate a significant amount of divalent transition metals (MO) as nominally $\left(\mathrm{Bi}_{2-x} \mathrm{M}_{x}\right) \mathrm{Ru}_{2} \mathrm{O}_{7-x / 2}$ solid solutions, which seems to be a major difference with $\mathrm{Pb}_{2} \mathrm{Ru}_{2} \mathrm{O}_{7-y}$, where such solid solutions were not detected with $\mathrm{CuO}^{505}$ For tetravalent $\mathrm{TiO}_{2}$, there is some disagreement as to the extent of $\mathrm{Bi}_{2}(\mathrm{Ru}, \mathrm{Ti})_{2} \mathrm{O}_{7}$ solid solutions. ${ }^{482,502}$ Additionally, one must note that these studies only give clues to the observed behaviour in real thick-film resistor systems, because a) the activities of the oxides are different when dissolved in glass, and b) thick-film resistors are usually non-equilibrium systems.

A more long-term potential development would be the avoidance of costly precious metals, by using other metallic (or almost metallic) oxides and compounds as conductive phases, of which a very wide variety exists, ${ }^{490}$ or metal borides, silicides etc. To circumvent the oftenobserved processing issues with nitrogen-firing thick-film resistors, ${ }^{183-189,}, 190,506$ air-firing systems should be developed. Several promising studies using molybdenum oxides have been carried out towards this goal, ${ }^{507-512}$ with the most recent embodiment ${ }^{512}$ having achieved transition to a bismuth glass frit, paving the way to low-cost lead-free resistors. These compositions are air-fireable, because the conductive phase, $\mathrm{MoO}_{2}$ and/or other intermediate oxides (which are unstable in air) form in situ, after densification of the glass frit, by reduction of $\mathrm{MoO}_{3}$. This is brought about by a suitable reducing agent, usually boron. Another base metal conductive filler successfully investigated with bismuth glasses is $\mathrm{SnO}_{2}: \mathrm{Sb}^{166}$ which seems however more suitable for higher ranges of surface resistance $(>100 \mathrm{k} \Omega)$, in line with the semiconductive properties of this filler. 


\section{Other applications}

\subsection{Optics}

Heavy metal ions such as $\mathrm{Bi}^{3+}, \mathrm{Pb}^{2+}$ and $\mathrm{Tl}^{+}$feature a unique combination of properties: high mass and polarisability, together with low bond strength. For optical applications of HMO materials, be it in glassy, ceramic or single-crystal form, this translates into high refractive indices $n$ (Table 22), dispersion and optical non-linear susceptibility $\chi^{(3)}$, as well as low phonon energies. ${ }^{36,112,124,128,329,371}$ In addition, low levels of partly reduced $\mathrm{Bi}$ in both Bibased and other glasses have been found to display broad IR luminescence, with possible application to optical amplification ${ }^{353,428-430}$ (see also discussion in supplement section 12). HMO glasses are a promising alternative to fluorides, ${ }^{37,192,193}$ due to their better chemical durability.

IR cut-off wavelength is related to the highest-frequency bond vibrations / maximum phonon energy. Therefore, HMO glasses for light amplification, and especially for far-IR transmission, should contain no standard network formers $\left(\mathrm{B}_{2} \mathrm{O}_{3}, \mathrm{SiO}_{2}, \mathrm{P}_{2} \mathrm{O}_{5}\right)$ or light intermediates with strong bonding such as $\mathrm{Al}_{2} \mathrm{O}_{3}$. Although $\mathrm{GeO}_{2}$ constitutes a good drop-in replacement for $\mathrm{SiO}_{2}$, much better infrared performance can be obtained (Table 22) with nonstandard formers such as $\mathrm{Ga}_{2} \mathrm{O}_{3}$ in the $\mathrm{PbO}-\mathrm{Bi}_{2} \mathrm{O}_{3}-\mathrm{Ga}_{2} \mathrm{O}_{3}$ system ${ }^{36,371}$ and $\mathrm{TeO}_{2}$ in $\mathrm{Bi}_{2} \mathrm{O}_{3}-$ $\mathrm{TeO}_{2}-\mathrm{WO}_{3},{ }^{123}$ and even systems entirely without glass formers such as $\mathrm{Li}_{2} \mathrm{O}-[\mathrm{BaO} / \mathrm{PbO}]-$ $\mathrm{Bi}_{2} \mathrm{O}_{3}{ }^{381,382,388}$ and $\mathrm{SrO}-\mathrm{PbO}-\mathrm{Bi}_{2} \mathrm{O}_{3} .{ }^{117}$ Considerable care must be exercised when melting $\mathrm{Bi}$ containing glasses for optical applications, as they are quite susceptible to reduction by trace organics or excessive melting temperatures (section 3.4), and to contamination by crucibles. ${ }^{36}$, ${ }^{387}$ Reduction or Pt pickup leads to darkening / staining of the glass, while even relatively low contamination by oxides such as $\mathrm{SiO}_{2}$ and $\mathrm{Al}_{2} \mathrm{O}_{3}$ will introduce high-frequency vibrations into the network, degrading far-IR transmission.

Obtaining a high refractive index and non-linear susceptibility, on the other hand, only involves the average glass properties, allowing limited use of standard network formers and thereby greatly facilitating vitrification. Synergistic vitrification through mixing of $\mathrm{SiO}_{2}, \mathrm{~B}_{2} \mathrm{O}_{3}$ and $\mathrm{Al}_{2} \mathrm{O}_{3}$ and substituting some $\mathrm{Bi}_{2} \mathrm{O}_{3}$ by $\mathrm{ZnO}$ (section 3.2) allows maximisation of $\mathrm{HMO}$ content; recent results on glasses optimised this way ${ }^{116}$ yield $n=2.31$ at $633 \mathrm{~nm}$ and $\chi^{(3)}=$ $4.9 \times 10^{-11}$ esu at $748 \mathrm{~nm}$. The glass composition was not specified exactly, but mentioned as $\mathrm{Bi}_{2} \mathrm{O}_{3}-\mathrm{B}_{2} \mathrm{O}_{3}-\mathrm{SiO}_{2}$, and is probably close to Smt-7 (Table 7). The high and very fast response of these glasses makes them very promising for high-frequency fully optical switching. ${ }^{112}$

In the case of upconversion, recent measurements ${ }^{119}, 371$ indicate that average properties (phonon density) rather than maximal phonon energy dominates efficiency, which is supported by the good results achieved by others with doped/codoped HMO glasses containing a low amount of network formers, ${ }^{121,124,125,325,370}$ usually $\mathrm{GeO}_{2}$ given its lower impact on performance. An additional advantage of $\mathrm{Bi}_{2} \mathrm{O}_{3}$-based $\mathrm{HMO}$ glasses for this application is their good compatibility with lanthanide additions (section 3.2).

Finally, the above considerations, though essentially focussed on glasses, are also applicable to similar crystalline (single-crystal, ceramic or glass-ceramic) compounds, of which many exhibit promising optical properties. ${ }^{351}$

\subsection{Gamma-ray protection glasses}

Due to their ideal combination of high $\gamma$-ray absorption coefficient (imparted by their large atomic mass) and good glass-forming ability as oxides, $\mathrm{Pb}$ and $\mathrm{Bi}$ are useful in $\gamma$-rayabsorbing windows in the nuclear industry and high-energy physics. ${ }^{129-135}$ Requirements for these glasses are in general similar to that for nonlinear optics: a HMO glass is needed for a 
good attenuation factor, but moderate concentrations of traditional network formers $\left(\mathrm{B}_{2} \mathrm{O}_{3}\right.$ \& $\mathrm{SiO}_{2}$ ) are allowed, facilitating fabrication of the thick parts needed for good shielding.

An early study of was carried out by Brekhovskikh in the $\mathrm{PbO}-\mathrm{Bi}_{2} \mathrm{O}_{3}-\mathrm{SiO}_{2}$ system; ${ }^{129}$ ternary glasses down to ca. $17 \% \mathrm{SiO}_{2}$ and with density $>8^{\prime} 000 \mathrm{~kg} \mathrm{~m}^{-3}$ could be manufactured (Rad-1), but practical considerations (need for casting in thick sections requires ca. $30 \% \mathrm{SiO}_{2}$, Rad-2). An analogous borate glass ( $\left.\operatorname{Rad}-4, \approx 21 \% \mathrm{BO}_{1.5}\right)$ was formulated ${ }^{130}$, but no indication was given on its castability in thick sections. The claim of a $\mathrm{Bi}_{2} \mathrm{O}_{3}-\mathrm{SiO}_{2}$ glass with $\approx 95 \%$ cation $\mathrm{Bi}$ is ${ }^{131}$ is dubious, as the indicated density of $7284 \mathrm{~kg} / \mathrm{m}^{3}$ corresponds to ca. $70 \% \mathrm{Bi}^{248}$ In the light of section 3.2, maximising $\mathrm{HMO}$ content in a Bi-based $\mathrm{Pb}$-free glass would most likely best be achieved in a more complex system, such as $\mathrm{SrO}-\mathrm{BaO}-\mathrm{ZnO}-$ $\mathrm{Bi}_{2} \mathrm{O}_{3}-\mathrm{Al}_{2} \mathrm{O}_{3}-\mathrm{B}_{2} \mathrm{O}_{3}-\mathrm{SiO}_{2}$. Compared to $\mathrm{PbO}, \gamma$-ray attenuation coefficients with $\mathrm{Bi}_{2} \mathrm{O}_{3}$ are similar ${ }^{129,134}$ (the apparent observed increase when substituting $\mathrm{PbO}$ with $\mathrm{Bi}_{2} \mathrm{O}_{3}{ }^{130}$ is simply due to the "molecular" formulation, where $\mathrm{Bi}$ is counted twice vs. $\mathrm{Pb}$ ), yielding a progressive increase in HMO content from $69 \%$ to $79 \%$ on a cation basis.

Table 22. Optical properties of HMO glasses.

\begin{tabular}{lccc}
\hline Code & Refractive index $\boldsymbol{n}^{\dagger}$ & IR transmission cut-off $[\mu \mathrm{m}]^{*}$ & Density $\left[\mathrm{g} \mathrm{cm}^{-3}\right]$ \\
\hline Dmb-H & $2.6_{589}$ & $7.8_{30 / 2.0}$ & 7.90 \\
Dmb-EO & $2.5_{589}$ & $7.0_{30 / 2.0}$ & 8.19 \\
Dmb-IV & $2.4_{589}$ & $6.8_{30 / 2.0}$ & 8.29 \\
Dmb-D & $2.5_{589}$ & $6.0_{50 / 2.0}$ & 8.9 \\
\hline Fu-1 & & $8.0_{35 / 0.7}$ & \\
\hline McC-1 & $2.32_{633}$ & & 8.1 \\
McC-2 & $2.40_{633}$ & & 8.4 \\
\hline
\end{tabular}

Notes. $\uparrow$ At wavelength [nm] indicated in index. * Transmission [\%] and thickness [mm] given in index.

Table 23. Compositions of selected BiSCCO superconductors, given in cation molar proportions. $z=\mathrm{Pb} /(\mathbf{P b}+\mathbf{B i})$.

\begin{tabular}{lccccccl}
\hline Code & $\boldsymbol{z}$ & $\mathbf{P b}+\mathbf{B i}$ & Sr & Ca & $\mathbf{C u}$ & Other & Notes \\
\hline HTS-1 $^{99}$ & $20 \%$ & 2 & 2 & 2 & 3 & - & \\
HTS-2 $^{101}$ & $20 \%$ & 2 & 2 & 2 & 3 & $0.1 \mathrm{Mo}$ & \& other dopants \\
HTS-3 $^{102}$ & $20 \%$ & 4 & 3 & 3 & 4 & - & \\
HTS-4 $^{104}$ & $0 \%$ & 4 & 3 & 3 & 4 & $0.1 \mathrm{Al}$ & Mix of phases \\
\hline
\end{tabular}

Note: oxides $=\mathrm{PbO}, \mathrm{BiO}_{1.5}, \mathrm{SrO}, \mathrm{CaO}, \mathrm{CuO}_{y}$ ( $y$ preparation-dependent), $\mathrm{AlO}_{1.5} \& \mathrm{MoO}_{3}$. 
This said, the main issue with $\gamma$-ray protection glasses lies with radiation-induced darkening, for which results are relatively unclear. ${ }^{131-133,135}$ Significant darkening in the shortwavelength portion of the visible spectrum was observed after $2.5 \mathrm{kGy}$ from ${ }^{60} \mathrm{Co}$, but no systematic trend vs. composition was observed for $\mathrm{Bi}_{2} \mathrm{O}_{3}-\mathrm{B}_{2} \mathrm{O}_{3}$ glasses, ${ }^{133}$ which is also the case for $\mathrm{Bi}_{2} \mathrm{O}_{3}-\mathrm{SiO}_{2}$ glasses after 10, 20 and $40 \mathrm{kGy}{ }^{60} \mathrm{Co} .{ }^{131}$ This darkening on the other hand was absent or very low in the visible for $\mathrm{Bi}_{2} \mathrm{O}_{3}-\mathrm{B}_{2} \mathrm{O}_{3}$ glasses optionally doped with $\mathrm{CuO}_{y}$ after up to $50 \mathrm{kGy}{ }^{60} \mathrm{Co} .{ }^{132}$ Although these latter results are very encouraging, systematic studies of the mechanisms of radiation-induced damage and of the good resistance against it of some glasses, including doping / impurity effects, still need to be carried out to reliably achieve low-darkening Bi-based glasses.

\section{3. $\mathrm{Bi}_{2} \mathrm{O}_{3}$ in (glass-)ceramics and crystals}

A short discussion is given in this section of $\mathrm{Bi}_{2} \mathrm{O}_{3}$ in five types of crystalline materials: 1) piezoceramics, 2) ionic and mixed conductors with high oxygen mobility, 3) hightemperature superconductors, 4) scintillators, and 5) ferroelectric memories. Besides these applications, $\mathrm{Bi}_{2} \mathrm{O}_{3}$ is a component of many electroceramics, in both the active crystalline phase or as a sintering aid, ${ }^{9}$ and compounds such as bismuth ruthenates $\left(\mathrm{Bi}_{2} \mathrm{Ru}_{2} \mathrm{O}_{7} /\right.$ $\mathrm{Bi}_{3} \mathrm{Ru}_{3} \mathrm{O}_{11}$ ), besides being a useful conductive phase for thick-film resistors (see section 4.6), are envisioned as chemical catalysts and electrodes. ${ }^{499,}{ }^{513}$ Bismuth vanadate $\left(\mathrm{BiVO}_{4}\right)$ is a relatively new yellow pigment that provides an alternative to toxic $\mathrm{Pb}$ - and $\mathrm{Cd}$-based pigments, ${ }^{514}$ and crystalline bismuth borates have interesting optical properties, ${ }^{351}$ akin to the corresponding glasses (see section 5.1). A quite extensive list of $\mathrm{Bi}_{2} \mathrm{O}_{3}$-based compounds and corresponding applications is given in recent work, ${ }^{403,515}$ together with an extensive discussion on their structural features (some of which are also discussed in supplementary section 13, as they yield insight into the structure of the corresponding glasses). Finally, it is worth mentioning that derivatives of the analogous chalcogenide, $\mathrm{Bi}_{2} \mathrm{Te}_{3}$, are the dominant room-temperature thermoelectric materials. ${ }^{516}$

\section{1) Piezoceramics}

Besides glass, the main application of PbO-bearing materials is arguably $\mathrm{PZT}=\mathrm{Pb}(\mathrm{Zr}, \mathrm{Ti}) \mathrm{O}_{3}$ and similar ceramics, mainly used for their large piezoelectric or electrostrictive properties. As these ceramics are present in many small essentially disposable electronic devices, considerable effort has been devoted to finding lead-free substitutes with at least acceptable performance. Recently, complex mixtures of $\mathrm{Bi}_{2} \mathrm{O}_{3}$ perovskite compounds such as $\mathrm{Bi}_{0.5}(\mathrm{Na}, \mathrm{K})_{0.5} \mathrm{TiO}_{3} \& \mathrm{Bi}(\mathrm{Fe}, \mathrm{Sc}) \mathrm{O}_{3}$ with $(\mathrm{Ba}, \mathrm{Sr}) \mathrm{TiO}_{3} \&(\mathrm{Na}, \mathrm{K}) \mathrm{NbO}_{3}$ have given rise to promising materials achieving strains comparable to that of the classical PZT ceramics, although many issues remain. ${ }^{517,} 518$ Note that bismuth titanate $\left(\mathrm{Bi}_{4} \mathrm{Ti}_{3} \mathrm{O}_{12}\right)$ is also a piezoceramic, albeit a specialised, high-temperature and low-activity one.

\section{2) Ionic and mixed ionic-electronic conductors with high oxygen mobility}

The high-temperature disordered defect-fluorite cubic $\delta-\mathrm{Bi}_{2} \mathrm{O}_{3}$ phase contains a very large amount of disordered oxygen vacancies - it may in fact be written as $\mathrm{Bi}\left(\mathrm{O}_{3 / 4} \square_{1 / 4}\right)_{2}$, i.e. with $1 / 4$ of the oxygen anion sublattice randomly empty - and therefore exhibits exceptionally high ionic conductivity. Although $\delta-\mathrm{Bi}_{2} \mathrm{O}_{3}$ is only stable above $730^{\circ} \mathrm{C}$, Takahashi et al. ${ }^{519}$ established that this disordered phase may be stabilised at lower temperatures - much like cubic zirconia - by various dopants, thus giving birth to a new family of solid electrolyte materials ${ }^{519-522}$ with high ionic conductivity at moderate temperatures. For instance, $\mathrm{Bi}_{2} \mathrm{O}_{3}$ solid solutions stabilised by oxides such as $\mathrm{Y}_{2} \mathrm{O}_{3}$ or $\mathrm{Er}_{2} \mathrm{O}_{3}$ have ionic conductivities exceeding $1 \mathrm{~S} / \mathrm{m}$ at $500^{\circ} \mathrm{C}$, more than $20 \times$ that of cubic or tetragonal zirconia, and more recent "BIMEVOX" materials with an oxygen-deficient Aurivillius structure have even higher 
conductivity. However, as all $\mathrm{Bi}_{2} \mathrm{O}_{3}$-based materials, these ionic conductors have limited stability towards reduction, and their use is limited in solid-oxide fuel cell (SOFC) applications. Nevertheless, they may still be used to this end, provided the reduction potential is limited or a thin protective layer of another electrolyte material is used on the reducing side. In addition, $\mathrm{Bi}_{2} \mathrm{O}_{3}$ ionic and mixed ionic-electronic conductors may find other important applications such as air-side electrodes for SOFCs, chemical electrodes, oxygen sensing and oxygen extraction from air. ${ }^{521,523}$

\section{3) High-temperature superconductor (HTS) materials}

The discovery of high-temperature $(>100 \mathrm{~K})$ superconductivity in the $\mathrm{Bi}-\mathrm{Sr}-\mathrm{Ca}-\mathrm{Cu}$ oxide ("BiSCCO") family (with possible substitution of $\mathrm{Bi}$ by $\mathrm{Pb}$ ) $99,524,525$ having low melting points opened up the possibility of greatly easier processing of these materials. In fact, these HTS compounds have compositions (examples in Table 23) corresponding to the "heavymetal oxide" glasses, ${ }^{36}$ and are therefore amenable to processing by the vitroceramic route, i.e. glass melting and quenching, followed by shaping and finally crystallisation and annealing to yield the superconducting phase ${ }^{39,99,101,102,104,105}$ with zero-resistance temperatures in excess of $100 \mathrm{~K}$ under optimal conditions. ${ }^{101}$ Low concentrations of suitable dopants do not significantly enhance the superconducting properties, but are added to facilitate processing and yield more consistent products. Reported melting temperatures are in the $1100-1300^{\circ} \mathrm{C}$ range, with long-term annealing around $850^{\circ} \mathrm{C}$ to form the superconducting phase(s). These materials feature rather high resistivity in their glassy state, ${ }^{100}$ in contrast to amorphous $\mathrm{Bi}_{3} \mathrm{Ru}_{3} \mathrm{O}_{11}{ }^{499}$

Besides these materials, doping $\mathrm{BaBiO}_{3}$ (with $\mathrm{Bi}$ in mixed +3 and +5 valence) with $\mathrm{K}$ or $\mathrm{Pb}$ yields $(\mathrm{Ba}, \mathrm{K}) \mathrm{BiO}_{3}$ or $\mathrm{Ba}(\mathrm{Bi}, \mathrm{Pb}) \mathrm{O}_{3}$ respectively, yields superconductors with transition temperatures up to $30 \mathrm{~K}$ that are of theoretical interest due to their simple cubic structure. ${ }^{526}$

\section{4) Scintillators}

In addition to heavy glasses potentially improving scintillation efficiency, ${ }^{36}$ crystals such as $\mathrm{Bi}_{4} \mathrm{Ge}_{3} \mathrm{O}_{12}, \mathrm{Bi}_{4} \mathrm{Si}_{3} \mathrm{O}_{12}$ and their solid solutions ${ }^{368,527,528}$ are useful as $\gamma$-ray scintillators, the active ion in this case being directly $\mathrm{Bi}^{3+}$ (i.e. "self-activated"). Potential preparation of $\mathrm{Bi}_{4} \mathrm{Ge}_{3} \mathrm{O}_{12}$ by the glass-ceramic route has been explored. ${ }^{368}$

\section{5) Ferroelectric memories}

Besides being useful as a piezoceramic, PZT in thin-film form is also of interest for nonvolatile ferroelectric memories. However, it was soon realised that its sensitivity to so-called fatigue, i.e. degradation upon repeated switching, was an important issue, although alleviated by the use of oxide electrode contacts. ${ }^{529}$ This problem was largely solved by the introduction of Aurivillius-type layered perovskite compounds derived from $\mathrm{Bi}_{4} \mathrm{Ti}_{3} \mathrm{O}_{12}$ such as $\mathrm{Bi}_{3.25} \mathrm{La}_{0.75} \mathrm{Ti}_{3} \mathrm{O}_{12}$ (simple substitution with $\mathrm{La}$ ), ${ }^{530} \mathrm{SrBi}_{2} \mathrm{Ta}_{2} \mathrm{O}_{9}{ }^{531}$ or $\mathrm{SrBi}_{4} \mathrm{Ti}_{4} \mathrm{O}_{15}$, ${ }^{532}$ which feature vastly improved switching endurance. 


\section{Conclusions}

The many examples discussed in this review show that replacement of lead by bismuth in TF and related glass frits seems the most feasible route in the short to middle term. In fact, this is already happening in several important industries such as electronics, displays and automotive/ architectural glass, in spite of the still considerable technological issues. Moreover, promising new applications are currently undergoing development in the sensors and optics field.

The considerably higher price of bismuth, ca. $10 \times$ that of lead ${ }^{533}$ should not constitute a problem in many high-added-value applications, where a relatively low overall volume of material is used, such as TF electronics, sensor cells and specialised optics. Moreover, $\mathrm{Bi}$ is not expected to replace lead in high-volume applications such as vehicle batteries, and only to a very modest extent in electronic solders, Bi-Sn and similar low-melting eutectic solder having only limited use. The same applies for use of $\mathrm{Pb}$-Bi eutectic (LBE) coolants. ${ }^{422}$

For thick-film electronics, the very strong increase in prices of all noble metals $(\mathrm{Ag}, \mathrm{Pd}, \mathrm{Pt}$, $\mathrm{Ru})$ in recent times ${ }^{533}$ is therefore a much more pressing issue for conductor and resistor materials. Development should be concentrated on new materials which reduce or altogether avoid their use, as has already been initiated for resistors. ${ }^{166,512}$ On the other hand, the price of Bi can be a factor in high-volume and very cost-sensitive architectural and automotive applications, ${ }^{47}$ so further developments to reduce its use in these sectors are likely.

From a scientific point of view, more well-controlled experimental data is necessary for bismuth-based glasses, as the reported results, especially on glass stability and properties, are somewhat conflicting, even for the simplest systems. Detailed studies on devitrification, separately assessing the composition-dependent dynamics of crystal nucleation and growth, are strongly needed as well, especially in the practically important low-melting borosilicates and HMO gallate systems.

Also, the very disordered structure $\mathrm{Bi}^{3+}$ adopts within the glass network - and how it is influenced by glass composition and thermal history - requires further clarification, especially in the light of recent structural studies ${ }^{403}$ on the peculiar behaviour of "lone-pair" ions such as $\mathrm{Bi}^{3+}, \mathrm{Sb}^{3+}, \mathrm{Pb}^{2+}$ and $\mathrm{Sn}^{2+}$ (see also supplementary section 13). Apparently, PbO-based glasses and two important envisioned substitutes, those based on $\mathrm{Bi}_{2} \mathrm{O}_{3}$ and on $\mathrm{SnO}$, share fundamental structural features. Extending the detailed structural studies and computer modelling to glasses would lead to a clearer picture of how glass formation and structure are affected by the stereochemically active lone pair, the valence and the polarisability.

Finally, it must be noted that this review has only dealt with relatively standard glassmaking techniques of Bi-based glasses; chemical methods such as solution coating of powders, nanopowder synthesis or sol-gel casting ${ }^{534}$ constitute promising alternative routes, potentially allowing the manufacture of novel glasses and glass-matrix composites with a degree of control not achievable by standard methods.

\section{Acknowledgements}

The author gratefully acknowledges partial financial support from the Swiss National Science Foundation NCCR CO-ME programme, as well as the assistance and patience of present and former colleagues at EPFL, especially C. Jacq and M. Garcin for experimental work and help from N. Takano and I. Stolichnov with Japanese- and Russian-only sources. The coordination shell drawings were created with the Avogadro molecular editing software. 


\section{References}

1. T. Maeder, C. Jacq, C. Grimaldi, and P. Ryser: 'Lead-free low-firing thick-film resistors based on bismuth glasses and ruthenium oxide', XXXIII International Conference of IMAPS Poland Chapter, Gliwice - Pszczyna (PL), 2009-09, 2009, 222-229.

2. I. W. Donald: 'Inorganic glasses and glass-ceramics: a review', Atomic Weapons Research Establishment (AWRE), UK, 1984.

3. N. Bansal and R. Doremus: 'Handbook of Glass Properties', Academic Press, Orlando, USA, 1986.

4. M. B. Volf: 'A Technical Approach to Glass'; 1990, Amsterdam (NL), Elsevier.

5. C. R. Kurkjian and W. R. Prindle: 'Perspectives on the history of glass composition', J. Am. Ceram. Soc., 1998, 81(4), 795-813.

6. D. C. Boyd, P. S. Danielson, D. A. Thompson, M. Velez, S. T. Reis, and R. K. Brow: 'Glass', in 'Kirk-Othmer Encyclopedia of Chemical Technology, 5 ${ }^{\text {th }}$ edition', 565-626; 2005.

7. I. Donald: 'Novel glasses and their applications', Discovery - The Science \& Technology Journal of AWE, 2001(2), 2-9.

8. I. Donald: 'Methods for improving the mechanical properties of oxide glasses', Journal of Materials Science, 1989, 24(12), 4177-4208.

9. M. T. Sebastian and H. Jantunen: 'Low loss dielectric materials for LTCC applications: a review', International Materials Reviews, 2008, 53(2), 57-90.

10. C. Leiser: 'Importance of lead in glass - Part one', The Glass Industry - the Journal of Glass Manufacturing, 1962, 44, 509-513.

11. C. Leiser: 'Importance of lead in glass - Parts two / III (conclusion)', The Glass Industry - the Journal of Glass Manufacturing, 1963, 45, 574-576; 630-632.

12. E. Rabinovich: 'Lead in glasses', Journal of Materials Science, 1976, 11, 925-948.

13. N. M. Bobkova: 'Low-melting glasses based on lead-borate systems (review)', Glass and Ceramics, 2009, 66(5-6), 206-209.

14. W. J. Scott: 'Glass-to-metal seal design', Journal of Scientific Instruments, 1946, 23(9), 193202.

15. J. Broukal: 'Beitrag zur Untersuchung der in der Vakuumelektronik verwendeten Sondergläser (Glaslote) [Contribution to the investigation of the special glasses used in vacuum electronics (sealing glasses)]', Silikattechnik, 1962, 13(12), 428-433.

16. J. Broukal: 'Thermisch entglasbare Glaslote [Thermally devitrifying sealing glasses]', Silikattechnik, 1966, 17(8), 242-248.

17. R. Frieser: 'A review of solder glasses', Electrocomponent Science and Technology, 1975, 2, 163-199.

18. H. Paschke: 'Die Anwendung von Glasloten [The application of solder glasses]', DVSBerichte, 1980, 66, 177-178.

19. E. M. Rabinovich: 'Solder glasses and vitreocrystalline cements', Inorganic Materials, 1976, 11, 925-948.

20. I. W. Donald: 'Preparation, properties and chemistry of glass-ceramic-to-metal seals and coatings', Journal of Materials Science, 1993, 28(11), 2841-2886.

21. M. Monneraye: 'Les encres sérigraphiables en microélectronique hybride: les matériaux et leur comportement [Screenable inks in hybrid microelectronics: the materials and their behaviour]', Acta Electronica, 1978, 21(4), 263-281. 
22. L. Hoffman: 'An overview of thick film hybrid materials', Am. Ceram. Soc. Bull., 1984, 63(4), $572-576$

23. T. Wada, S. Stein, M. Stein, and S. Chitale: 'The state-of-the-art of thick film technology for automotive sensors', Proceedings, IEMT/IMC Symposium, 1997, 41-46.

24. J. E. Sergent: 'Hybrid microelectronics technology', in 'Electronic Systems Maintenance Handbook, $2^{\text {nd }}$ edition', (ed. J. C. Whitaker), chapter 11; 2002, CRC Press (USA).

25. K. Pitt, ed. Handbook of thick film technology, $2^{\text {nd }} e d$., 2005, Isle of Man, Electrochemical Publications.

26. N. M. White: 'Advances in thick-film sensors', $14^{\text {th }}$ International Conference on Solid-State Sensors, Actuators and Microsystems - Transducers / Eurosensors'07, Lyon (FR), 2007-06, 2007, IEEE, 107-111.

27. C. Jacq, T. Maeder, and P. Ryser: 'Sensors and packages based on LTCC and thick-film technology for severe conditions', SĀDHANĀ - Acad. Proc. Eng. Sci., 2009, 34(4), 677-687.

28. C. Jacq, T. Maeder, and P. Ryser: 'High-strain response of piezoresistive thick-film resistors on titanium alloy substrates', J. Eur. Ceram. Soc., 2004, 24(6), 1897-1900.

29. M. Shimbo, S. Tai, and K. Tanzawa: 'Glass formation range, acid resistivity, and surface charge density of $\mathrm{ZnO}-\mathrm{B}_{2} \mathrm{O}_{3}-\mathrm{SiO}_{2}$ passivation glass containing $\mathrm{Al}_{2} \mathrm{O}_{3}^{\prime}$, J. Am. Ceram. Soc., 1986, 69(1), 23-26.

30. M. Shimbo and K. Furukawa: 'Physical and electrical properties of acid resistive zinc - lead borosilicate passivation glass', Journal of the Ceramics Society of Japan, International Edition, 1988, 96, 201-205.

31. N. M. Bobkova: 'Glass enamels in the electronics industry', Glass and Ceramics, 1995, 52(5), 107-111.

32. V. V. Gerasimov and O. V. Spirina: 'Low-melting borosilicate glazes for special-purpose and construction ceramics (a review)', Glass and Ceramics, 2004, 61(11-12), 382-388.

33. G. L. Heider: 'Bismuth key to lead-free success', Glass, 1992, 69(7), 273-275.

34. I. N. Yashchishin, O. F. Babadzhanova, and V. A. Vasiichuk: 'Low-melting coatings for glass decoration', Glass and Ceramics, 2001, 58(7-8), 287-289.

35. M. Leveaux, N. Crevit, K. Lips, B. Schepers, A. Aerts, and E. Verboom: 'Nuovi orizzonti nella smaltatura dell'alluminio [New horizons in the enamelling of aluminium]', Smalto Porcellanato - Tecnologia e Mercati, 2002, 44(2).

36. W. H. Dumbaugh and J. C. Lapp: 'Heavy-metal oxide glasses', J. Am. Ceram. Soc., 1992, 75(9), 2315-2326.

37. G. Rault, J. Adam, F. Smektala, and J. Lucas: 'Fluoride glass compositions for waveguide applications', Journal of Fluorine Chemistry, 2001, 110, 165-173.

38. E. E. Stroganova, N. Y. Mikhailenko, and O. A. Moroz: 'Glass-based biomaterials: present and future (a review)', Glass and Ceramics, 2003, 70(9-10), 315-319.

39. N. V. Shishkov: 'Superconducting glass-ceramics in the Bi-Sr-Ca-Cu-O system - a review', Glass and Ceramics, 1992, 49(9), 16-20.

40. D. Erickson and D. Q. Li: 'Integrated microfluidic devices', Analytica Chimica Acta, 2004, 507(1), 11-26.

41. M.-A. Schneider, T. Maeder, P. Ryser, and F. Stoessel: 'A microreactor-based system for the study of fast exothermic reactions in liquid phase: characterization of the system', Chemical Engineering Journal, 2004, 101, 241-250. 
42. G. C. Cheek, R. P. Mertens, R. Van Overstraeten, and L. Frisson: 'Thick-film metallization for solar cell applications', IEEE Transactions on Electron Devices, 1984, 31(5), 602-605.

43. G. Schubert, F. Huster, and P. Fath: 'Physical understanding of printed thick-film front contacts of crystalline Si solar cells-Review of existing models and recent developments', Solar Energy Materials \& Solar Cells, 2006, 90(18-19), 3399-3406.

44. R. Krüger, A. Roosen, and W. Schaper: 'Hermetic glass sealing of AlN packages for high temperature applications', J. Eur. Ceram. Soc., 1999, 19(6-7), 1067-1070.

45. D. A. Geodakyan, B. V. Petrosyan, S. V. Stepanyan, and K. D. Geodakyan: 'Investigation of the possibility of replacing high-lead glasses in fusible glass solders by less toxic glasses', Glass and Ceramics, 2009, 66(11-12), 381-384.

46. E. V. Shinkareva: 'Lead-free enamels for decoration of glass articles', Glass and Ceramics, 2004, 61(9-10), 303-305.

47. G. E. Sakoske: 'Functional glass coatings (presentation)', IMI International Workshop on Scientific Challenges of New Functionalities in Glass, Washington DC (USA), 16.4.2007, 2007.

48. C. Fredericci, H. N. Yoshimura, A. L. Molisani, and H. Fellegara: 'Effect of $\mathrm{TiO}_{2}$ addition on the chemical durability of $\mathrm{Bi}_{2} \mathrm{O}_{3}-\mathrm{SiO}_{2}-\mathrm{ZnO}-\mathrm{B}_{2} \mathrm{O}_{3}$ glass system', Journal of Non-Crystalline Solids, 2008, 354(42-44), 8592-8598.

49. C. R. Needes: 'Thick film silver metallizations for silicon solar cells', Patent US4235644, 1980-11, 1980.

50. C. Ballif, D. M. Huljic, G. Willeke, and A. Hessler-Wyser: 'Silver thick-film contacts on highly doped n-type silicon emitters: structural and electronic properties of the interface', Appl. Phys. Lett., 2003, 82(12), 1878-1880.

51. Y. L. Wang and K. W. Hang: 'Electroconductive thick film composition(s), electrode(s), and semiconductor device(s) formed therefrom', Patent US2006/0231803, USA, 2006.

52. S. B. Cho, K. K. Hong, B. M. Chung, and J. Y. Huh: 'Influence of firing ambience on firethrough silver contact metallization for crystalline silicon solar cells', $34^{\text {th }}$ IEEE Photovoltaic Specialists Conference (PVSC), Philadelphia (USA), 2009, IEEE, 766-769.

53. S. J. Jeon, S. M. Koo, and S. A. Hwang: 'Optimization of lead- and cadmium-free front contact silver paste formulation to achieve high fill factors for industrial screen-printed $\mathrm{Si}$ solar cells', Solar Energy Materials \& Solar Cells, 2009, 93(6-7), 1103-1109.

54. S. Y. Eliseev, S. P. Rodtsevich, and G. F. Lukashevich: 'A low-boron dielectric coating for aluminum', Glass and Ceramics, 2000, 57(11-12), 402-403.

55. E. A. Yatsenko, A. P. Zubekhin, and E. A. Shkurakova: 'Tinted low-melting enamels for aluminum', Glass and Ceramics, 2001, 58(11-12), 428-430.

56. M. Leveaux and S. Humez: 'Particular compositions of porcelain enamels', Patent EP1331207, Europe, 2003.

57. A. Monzio Compagnoni and A. Ferraro: 'Smaltatura dell'aluminio ad alto tenore di magnesio [enamelling of aluminium with high magnesium content]', Smalto Porcellanato - Tecnologia e Mercati, 2005, 47(2).

58. A. Monzio Compagnoni: 'Riduzione o eliminazione del vanadio nello smalto per alluminio [Reduction or elimination of vanadium in enamels for aluminium]', Smalto Porcellanato Tecnologia e Mercati, 2006, 48(1).

59. R. Vest: 'Materials science of thick film technology', Am. Ceram. Soc. Bull., 1986, 65(4), 631636. 
60. R. Dell'Acqua: 'Substrates for thick film technology', in 'Thick Film Sensors', (ed. M. Prudenziati), 59-72; 1994, Amsterdam (NL), Elsevier.

61. J. S. Shah and W. C. Hahn: 'Material characterization of thick film-resistor pastes', IEEE Transactions on Components, Hybrids, and Manufacturing Technology, 1978, 1(4), 383-392.

62. M. Prudenziati and R. Dell'Acqua: 'Thick film resistors', in 'Thick Film Sensors', 85-97; 1994, Amsterdam (NL), Elsevier.

63. R. Dell'Acqua: 'Thick films conductors', in 'Thick Film Sensors', (ed. M. Prudenziati), 73-83; 1994, Amsterdam (NL), Elsevier.

64. S. F. Wang, J. P. Dougherty, and W. Huebner: 'Silver-palladium thick-film conductors', J. Am. Ceram. Soc., 1994, 77(12), 3051-3072.

65. R. Dell'Acqua: 'Thick-film dielectric materials', in 'Thick Film Sensors', (ed. M. Prudenziati), 99-111; 1994, Amsterdam (NL), Elsevier.

66. Y. H. Hsieh and S. H. Fu: ' $\mathrm{BaPbO}_{3}$-based thick film resistor', IEEE Transactions on Components, Hybrids, and Manufacturing Technology, 1992, 15(3), 348-352.

67. C. Jacq, T. Maeder, S. Martinerie, G. Corradini, M. Carreño, E., and P. Ryer: 'High performance thick-film pressure sensors on steel', 4th European Microelectronics and Packaging Symposium, Terme Čatež (SI), 2006-05, 2006, IMAPS, 105-109.

68. C. Jacq, T. Maeder, and P. Ryser: 'Piezoresistive properties of low-firing temperature thickfilms on steel sensors', $4^{\text {th }}$ International Conference on Ceramic Interconnect and Ceramic Microsystems Technologies (CICMT), Munich (DE), 2008-04, 2008, IMAPS, 411-416 (P413).

69. C. Jacq, T. Maeder, and P. Ryser: 'Load sensing surgical instruments', Journal of Materials Science: Materials in Medecine, 2009, 20(S1), S223-S227.

70. M. Totokawa, S. Yamashita, K. Morikawa, Y. Mitsuoka, T. Tani, and H. Makino: 'Microanalyses on the $\mathrm{RuO}_{2}$ particle-glass matrix interface in thick-film resistors with piezoresistive effects', Int. J. Appl. Ceram. Tech., 2009, 6(2), 195-204.

71. T. Maeder, C. Jacq, and P. Ryser: 'Low-firing thick-film piezoresistive sensors for medical instruments', Sens. Actuat. A, 2011, 172(1), 228-232.

72. I. Kaneko, S. Tagushi, and T. Kashiwagi: 'Metal-glazed thick-film resistors fired at low temperature on glass substrate', IEICE Transactions on Electronics, 2000, E83-C(10), 16691676.

73. W. Sack, H. Scheidler, and J. Petzoldt: 'Zum Kristallisationsverhalten der Glaslote [On the crystallisation behaviour of sealing glasses]', Glastechnische Berichte, 1968, 41(4), 138-145.

74. W. Hinz and G. Solow: 'Bemerkungen zu entglasenden Verbindungsgläsern [Remarks on devitrifying sealing glasses]', Silikattechnik, 1962, 13(8), 272-278.

75. J. G. Bobinski: 'Low temperature sealing glass', Patent US6248679, USA, 2001-06, 2001.

76. M. Prudenziati, B. Morten, F. Cilloni, G. Ruffi, and M. Sacchi: 'Interactions between alumina and high lead glasses for hybrid components', Journal of Applied Physics, 1989, 65(1), 146153.

77. M. Prudenziati, B. Morten, G. Ruffi, E. Argentino, and C. Iachetti: 'Size effect due to silver diffusion in $\mathrm{RuO}_{2}$-based resistors', $7^{\text {th }}$ European Hybrid Microelectronics Conference, Hamburg (DE), 1989-05, 1989, ISHM, 162-169.

78. M. Prudenziati, B. Morten, F. Cilloni, and G. Ruffi: 'Very high strain sensitivity in thick-film resistors: real and false super gauge factors', Sensors and Actuators, 1989, 19(4), 401-414. 
79. M. Prudenziati, F. Sirotti, M. Sacchi, B. Morten, A. Tombesi, and T. Akomolafe: 'Size effects in ruthenium-based thick-film resistors: rutile vs. pyrochlore-based resistors', Active and Passive Electronics Components, 1991, 14(3), 163-173.

80. M. Prudenziati, B. Morten, P. Savigni, and G. Guizzeti: 'Influence of the preparing conditions on the physicochemical characteristics of glasses for thick film hybrid microelectronics', Journal of Materials Research, 1994, 9(9), 2304-2313.

81. M. Prudenziati, B. Morten, B. Forti, A. F. Gualtieri, and G. M. Dilliway: 'Devitrification kinetics of high lead glass for hybrid microelectronics', International Journal of Inorganic Materials, 2001, 3(7), 667-674.

82. L. C. Hoffman and S. J. Horowitz: 'Stable pyrochlore resistor compositions', Patent US4302362, USA, 1981.

83. S. Vionnet-Menot, C. Grimaldi, T. Maeder, P. Ryser, and S. Strässler: 'Study of electrical properties of piezoresistive pastes and determination of the electrical transport', J. Eur. Ceram. Soc., 2005, 25(12), 2129-2132.

84. S. Vionnet-Menot, C. Grimaldi, T. Maeder, P. Ryser, and S. Strässler: 'Tunneling-percolation origin of nonuniversality: Theory and experiments', Physical Review B, 2005, 71(6), 064201.

85. S. Vionnet-Menot: 'Low firing temperature thick-film piezoresistive composites - properties and conduction mechanism', PhD thesis, EPFL, Lausanne (CH), 2005.

86. S. Vionnet-Menot, T. Maeder, C. Grimaldi, C. Jacq, and P. Ryser: 'Properties and stability of thick-film resistors with low processing temperatures - effect of composition and processing parameters', J. Microelectron. Electron. Pack., 2006, 3(1), 37-43.

87. L. C. Hoffman: 'Metallizing compositions containing critical proportions of metal (Pt-Au or Pd-Au) and a specific high density frit', Patent US3440062, USA, 1969.

88. W. Zdaniewski and L. Silverman: 'Effect of localized redox equilibria on adhesion between gold and thick-film dielectrics', Journal of Materials Science, 1990, 25(7), 3155-3158.

89. M. Hynes and B. Jonson: 'Lead, glass and the environment', Chemical Society Reviews, 1997, 26, 133-146.

90. M. Hynes, S. Forde, and B. Jonson: 'Element migration from glass compositions containing no added lead', The Science of the Total Environment, 2004, 319(1), 39-52.

91. E. M. Levin, C. R. Robbins, and H. F. McMurdie, eds. Figures 1-2066, Vol. 1, 1964, Columbus (USA), American Ceramic Society.

92. E. M. Levin, C. R. Robbins, and H. F. McMurdie, eds. Figures 2067-4149, Vol. 2, 1969, Columbus (USA), American Ceramic Society.

93. E. M. Levin and H. F. McMurdie, eds. Figures 4150-4999, Vol. 3, 1975, Columbus (USA), American Ceramic Society.

94. R. Roth, T. Negas, L. Cook, and (editors): 'Phase diagrams for ceramists', American Ceramic Society, Columbus, USA, 1981, 4(5000-5590).

95. B. C. Sales and L. A. Boatner: 'Lead-iron phosphate glass: a stable storage medium for highlevel nuclear waste', Science, 1984, 226(4670), 45-48.

96. M. Karabulut, K. Marasinghe, C. S. Ray, D. E. Day, O. Ozturk, and G. D. Waddill: 'X-ray photoelectron and Mössbauer spectroscopic studies of iron phosphate glasses containing U, Cs and Bi', Journal of Non-Crystalline Solids, 1999, 249(2-3), 106-116.

97. S. T. Reis, M. Karabulut, and D. E. Day: 'Chemical durability and structure of zinc-iron phosphate glasses', Journal of Non-Crystalline Solids, 2001, 292(1-3), 150-157.

98. S. T. Reis, M. Karabulut, and D. E. Day: 'Structural features and properties of lead-ironphosphate nuclear wasteforms', Journal of Nuclear Materials, 2002, 304(2-3), 87-95. 
99. T. Komatsu, R. Sato, H. Meguro, K. Matusita, and T. Yamashita: 'Effect of copper content on glass formation and superconductivity in the Bi-Pb-Sr-Ca-Cu-O system', Journal of Materials Science, 1991, 26(3), 683-688.

100. K. K. Som, S. Molla, K. Bose, and B. K. Chaudhuri: 'Nonlinear physical properties of amorphous $\mathrm{Bi}_{4} \mathrm{Sr}_{3} \mathrm{Ca}_{3} \mathrm{Cu}_{y} \mathrm{O}_{x}$ semiconducting oxides with $y$ between 0 and 5', Physical Review $B, 1992, \mathbf{4 5}(4), 1655-1659$.

101. M. Tatsumisago, S. Inoue, N. Tohge, and T. Minami: 'Dopants in high- $T_{c}$ superconductors from rapidly quenched $\mathrm{Bi}_{1.6} \mathrm{~Pb}_{0.4} \mathrm{Ca}_{2} \mathrm{Sr}_{2} \mathrm{Cu}_{3} \mathrm{O}_{w}$ glasses', Journal of Materials Science, 1993, 28(15), 4193-4196.

102. Y. Hu, H. Zheng, and J. D. Mackenzie: 'High-Tc superconducting Bi(Al)-Ca-Sr-Cu-O glassceramic fibres drawn from glass preforms', Journal of Materials Science, 1995, 30(15), 39133918.

103. Y. Hu, N. Liu, and U. Lin: 'Glass formation and glass structure of the $\mathrm{BiO}_{1.5}-\mathrm{PbO}-\mathrm{CuO}$ system', Journal of Materials Science, 1998, 33(1), 229-234.

104. M. Gazda: 'The $(\mathrm{Bi}, \mathrm{Pb})_{4} \mathrm{Sr}_{3} \mathrm{Ca}_{3} \mathrm{Cu}_{4} \mathrm{O}_{x}$ glass-ceramics: disordered metal and superconductor', Journal of Non-Crystalline Solids, 2006, 352(40-41), 4246-4249.

105. M. Gazda, B. Kusz, and L. Murawski: 'Electronic conduction in ( $\mathrm{Bi}, \mathrm{Pb})-\mathrm{Sr}-\mathrm{Ca}-\mathrm{Cu}-\mathrm{O}$ granular superconductors', Journal of Non-Crystalline Solids, 2008, 354(35-39), 4323-4325.

106. W. H. Dumbaugh and B. P. Tyndell: ' $\mathrm{Bi}_{2} \mathrm{O}_{3}-\mathrm{Ga}_{2} \mathrm{O}_{3}$ glasses', Patent US4456692, USA, 1984.

107. G. S. Khalilov, M. V. Artamonova, and I. S. Shaplygin: 'Стеклооьразование в висмутобержащих оксибныих системах [Glass formation in bismuth-containing oxide systems]', Doklady Akademii Nauk SSSR, 1984, 276(4), 908-910.

108. Y. Dimitriev and V. Mihailova: 'Glass formation in binary systems with $\mathrm{Bi}_{2} \mathrm{O}_{3}$ and $\mathrm{PbO}$ participation', Journal of Materials Science Letters, 1990, 9, 1251-1254.

109. F. Miyaji, T. Yoko, J. Jin, S. Sakka, T. Fukunaga, and M. Misawa: 'Neutron and X-ray diffraction studies of $\mathrm{PbO}-\mathrm{Ga}_{2} \mathrm{O}_{3}$ and $\mathrm{Bi}_{2} \mathrm{O}_{3}-\mathrm{Ga}_{2} \mathrm{O}_{3}$ glasses', Journal of Non-Crystalline Solids, 1994, 175(2-3), 211-223.

110. C. Stehle, C. Vira, D. Hogan, S. Feller, and M. Affatigato: 'Optical and physical properties of bismuth borate glasses related to structure', Physics and Chemistry of Glasses, 1998, 39(2), 83-86.

111. Y. G. Choi, K. H. Kim, V. A. Chernov, and J. Heo: 'EXAFS spectroscopic study of PbO$\mathrm{Bi}_{2} \mathrm{O}_{3}-\mathrm{Ga}_{2} \mathrm{O}_{3}$ glasses', Journal of Non-Crystalline Solids, 1999, 259(1-3), 205-211.

112. N. Sugimoto, H. Kanbara, S. Fujiwara, K. Tanaka, Y. Shimizugawa, and K. Hirao: 'Thirdorder optical nonlinearities and their ultrafast response in $\mathrm{Bi}_{2} \mathrm{O}_{3}-\mathrm{B}_{2} \mathrm{O}_{3}-\mathrm{SiO}_{2}$ glasses', Journal of the Optical Society of America B, 1999, 16(11), 1904-1908.

113. S. Blanchandin, P. Thomas, P. Marchet, J. C. Champarnaud-Mesjard, and B. Frit: 'New heavy metal oxide glasses: investigations within the $\mathrm{TeO}_{2}-\mathrm{Nb}_{2} \mathrm{O}_{5}-\mathrm{Bi}_{2} \mathrm{O}_{3}$ system', Journal of Alloys and Compounds, 2002, 347(1-2), 206-212.

114. S. Ohara, N. Sugimoto, Y. Kondo, K. Ochiai, Y. Kuroiwa, J. Fukasawa, T. Hirose, H. Hayashi, and S. Tanabe: ' $\mathrm{Bi}_{2} \mathrm{O}_{3}$ - based Glass for S - band Amplification', 2003.

115. M. Milanova, R. Iordanova, Y. Dimitriev, and D. Klissurski: 'Glass formation in the $\mathrm{MoO}_{3}-$ $\mathrm{Bi}_{2} \mathrm{O}_{3}-\mathrm{PbO}$ system', Journal of Materials Science, 2004, 39(9), 5591-5593.

116. T. Hasegawa, T. Nagashima, and N. Sugimoto: 'Z-scan study of third-order optical nonlinearities in bismuth-based glasses', Optics Communications, 2005, 250(4-6), 411-415. 
117. H. Sun, S. Xu, S. Dai, L. Wen, J. Zhang, L. Hu, and Z. Jiang: 'Efficient frequency upconversion emission in $\mathrm{Er}^{3+}$-doped novel strontium lead bismuth glass', Journal of NonCrystalline Solids, 2005, 351(3), 288-292.

118. O. Sanz, E. Haro-Poniatowski, J. Gonzalo, and N. Fernández, J.M.: 'Influence of the melting conditions of heavy metal oxide glasses containing bismuth oxide on their optical absorption', Journal of Non-Crystalline Solids, 2006, 352(8), 761-768.

119. S. Dai, L. Lu, T. Xu, Q. Nie, X. Shen, and X. Wang: 'Optical properties of and concentration quenching in $\mathrm{Bi}_{2} \mathrm{O}_{3}-\mathrm{B}_{2} \mathrm{O}_{3}-\mathrm{Ga}_{2} \mathrm{O}_{3}$ glasses', Journal of Non-Crystalline Solids, 2007, 353(28), 2744-2749.

120. C. J. Hill and A. Jha: 'Development of novel ternary tellurite glasses for high temperature fiber optic mid-IR chemical sensing', Journal of Non-Crystalline Solids, 2007, 353(13-15), 13721376.

121. D. M. Shi, Q. Y. Zhang, G. F. Yang, and Z. H. Jiang: 'Spectroscopic properties and energy transfer in $\mathrm{Ga}_{2} \mathrm{O}_{3}-\mathrm{Bi}_{2} \mathrm{O}_{3}-\mathrm{PbO}-\mathrm{GeO}_{2}$ glasses codoped with $\mathrm{Tm}^{3+}$ and $\mathrm{Ho}^{3+1}$, Journal of NonCrystalline Solids, 2007, 353(16-17), 1508-1514.

122. S. Bale, S. Rahman, A. M. Awasthi, and V. Sathe: 'Role of $\mathrm{Bi}_{2} \mathrm{O}_{3}$ content on physical, optical and vibrational studies in $\mathrm{Bi}_{2} \mathrm{O}_{3}-\mathrm{ZnO}-\mathrm{B}_{2} \mathrm{O}_{3}$ glasses', Journal of Alloys and Compounds, 2008, 460(1-2), 699-703.

123. Y. Chen, Q. Nie, T. Xu, S. Dai, X. Wang, and X. Shen: 'A study of nonlinear optical properties in $\mathrm{Bi}_{2} \mathrm{O}_{3}-\mathrm{WO}_{3}-\mathrm{TeO}_{2}$ glasses', Journal of Non-Crystalline Solids, 2008, 354(29), 3468-3472.

124. N. Sugimoto: 'Erbium doped fiber and highly non-linear fiber based on bismuth oxide glasses', Journal of Non-Crystalline Solids, 2008, 354(12-13), 1205-1210.

125. G. F. Yang, D. M. Shi, Q. Y. Zhang, and Z. H. Jiang: 'Spectroscopic properties of $\mathrm{Er}^{3+} / \mathrm{Yb}^{3+}-$ codoped $\mathrm{PbO}-\mathrm{Bi}_{2} \mathrm{O}_{3}-\mathrm{Ga}_{2} \mathrm{O}_{3}-\mathrm{GeO}_{2}$ glasses', Journal of Fluorescence, 2008, 18(1), 131-137.

126. J. Ozdanova, H. Tichá, and L. Tichý: 'Optical band gap and Raman spectra in some $\left(\mathrm{Bi}_{2} \mathrm{O}_{3}\right)_{\mathrm{x}}\left(\mathrm{WO}_{3}\right)_{\mathrm{y}}\left(\mathrm{TeO}_{2}\right)_{100-\mathrm{x}-\mathrm{y}}$ and $(\mathrm{PbO})_{\mathrm{x}}\left(\mathrm{WO}_{3}\right)_{\mathrm{y}}\left(\mathrm{TeO}_{2}\right)_{100-\mathrm{x}-\mathrm{y}}$ glasses', Journal of Non-Crystalline Solids, 2009, 354(45-47), 3468-3472.

127. B. Zhou, E. Y. Pun, H. Lin, D. Yang, and L. Huang: 'Judd-Ofelt analysis, frequency upconversion, and infrared photoluminescence of $\mathrm{Ho}^{3+}$-doped and $\mathrm{Ho}^{3+} / \mathrm{Yb}^{3+}$-codoped lead bismuth gallate oxide glasses', Journal of Applied Physics, 2009, 106(10), 103105.

128. J. McCloy, B. Riley, B. Johnson, M. Schweiger, H. A. Qiao, and N. Carlie: 'The predictive power of electronic polarizability for tailoring the refractivity of high-index glasses: optical basicity versus the single oscillator model', J. Am. Ceram. Soc., 2010, 93(6), 1650-1662.

129. S. M. Brekhovskikh: 'Glasses with high bismuth and lead contents', Glass and Ceramics, 1957, 14(8), 264-267.

130. N. Singh and K. Singh: 'Comparative study of lead borate and bismuth lead borate glass systems as gamma-radiation shielding materials', Nuclear Instruments and Methods in Physics Research Section B, 2004, 225(3), 305-309.

131. F. H. El Batal: 'Gamma ray interaction with bismuth silicate glasses', Nuclear Instruments and Methods in Physics Research B, 2007, 254(2), 243-253.

132. F. H. El Batal, S. Y. Marzouk, N. Nada, and S. M. Desouky: 'Gamma-ray interaction with copper-doped bismuth-borate glasses', Physica B, 2007, 391(1), 88-97.

133. G. Sharma, K. S. Thind, Monika, H. Singh, Manupriya, and L. Gerward: 'Optical properties of heavy metal oxide glasses before and after $\gamma$-irradiation', Physica Status Solidi A, 2007, 204(2), 591-601. 
134. J. Kaewkhao, A. Pokaipisit, and P. Limsuwan: 'Study on borate glass system containing with $\mathrm{Bi}_{2} \mathrm{O}_{3}$ and $\mathrm{BaO}$ for gamma-rays shielding materials: Comparison with $\mathrm{PbO}^{\prime}$, Journal of Nuclear Materials, 2010, 399(1), 38-40.

135. Y. Ou, S. Baccaro, Y. Zhang, Y. Yang, and G. Chen: 'Effect of gamma-ray irradiation on the optical properties of $\mathrm{PbO}-\mathrm{B}_{2} \mathrm{O}_{3}-\mathrm{SiO}_{2}$ and $\mathrm{Bi}_{2} \mathrm{O}_{3}-\mathrm{B}_{2} \mathrm{O}_{3}-\mathrm{SiO}_{2}$ glasses', J. Am. Ceram. Soc., 2010, 93(2), 338-341.

136. D. W. Johnson and F. A. Hummel: 'Phase equilibria and liquid immiscibility in the system PbO- $\mathrm{B}_{2} \mathrm{O}_{3}-\mathrm{SiO}_{2}$ ', J. Am. Ceram. Soc., 1968, 51(4), 196-201.

137. N. Shinkai, R. Bradt, and G. Rindone: 'The hardness of PbO-ZnO- $\mathrm{B}_{2} \mathrm{O}_{3}$ glasses', Journal of Materials Science, 1983, 18(8), 2466-2270.

138. D. H. R. Sarma and R. W. Vest: 'Kinetics of liquid spreading and penetration with application to $\mathrm{RuO}_{2}$-glass thick-film resistors', J. Am. Ceram. Soc., 1985, 68(5), 249-253.

139. I. K. Nemkovich, O. V. Nevar, I. A. Formago, and I. E. Maksimova: 'Low-melting glasses for the potting of thick-film microcircuits', Glass and Ceramics, 1991, 48(12), 544-546.

140. D. M. Mattox and J. H. Robinson: 'Chemical durability of lead-oxide-based, thick-film binder glasses', J. Am. Ceram. Soc., 1997, 80(5), 1189-1192.

141. I. L. Trubnikov: 'Thermal expansion and corrosion behavior of lead-borosilicate glasses', Refractories and Industrial Ceramics, 2000, 41(5-6), 169-171.

142. S. Fujino, C. Hwang, and K. Morinaga: 'Density, surface tension, and viscosity of $\mathrm{PbO}-\mathrm{B}_{2} \mathrm{O}_{3^{-}}$$\mathrm{SiO}_{2}$ glass melts', J. Am. Ceram. Soc., 2004, 87(1), 10-16.

143. S. Fujino, C. Hwang, and K. Morinaga: 'Surface tension of $\mathrm{PbO}-\mathrm{B}_{2} \mathrm{O}_{3}$ and $\mathrm{Bi}_{2} \mathrm{O}_{3}-\mathrm{B}_{2} \mathrm{O}_{3}$ glass melts', Journal of Materials Science, 2005, 40, 2207-2212.

144. R. S. Roth, J. R. Dennis, and H. F. McMurdie, eds. Figures 6255-6951, Vol. 6, 1987, Columbus (USA), American Ceramic Society.

145. R. A. Busdiecker: 'Solder glass compositions and method of sealing metal therewith', Patent US3454408, USA, 1969.

146. L. C. Hoffman: 'Low melting glass and compositions containing the same', Patent US3480566, USA, 1969.

147. L. Finkelstein, M. E. Dumesnil, and R. R. Tetschlag: 'Sealing glass compositions', Patent US5013360, USA, 1991.

148. S. Mandal and A. Ghosh: 'Structure and physical properties of glassy lead vanadates', Physical Review B, 1993, 48(13), 9388-9394.

149. H. Hikata, K. Tanaka, and K. Shindo: 'Low temperature sealing composition', Patent US5346863, USA, 1994.

150. M. Busio and O. Steigelmann: 'New frit glasses for displays', Glass Science and Technology Glastechnische Berichte, 2000, 73(10), 319-325.

151. Y. Jimura and M. Hayashi: 'CRT frit capable of sealing a CRT bulb at a relatively low temperature and in a short time', Patent US6583079, USA, 2003.

152. Y. Cheng, H. Xiao, and W. Guo: 'Influence of compositions on sealing temperature and properties of lead borate non-crystallizing sealing glasses', Materials Science and Engineering A, 2007, 464(1-2), 210-215.

153. P. Tick: 'Water durable glasses with ultra low melting temperature', Physics and Chemistry of Glasses, 1984, 25(6), 149-154.

154. E. F. Smith: 'Sealing glass composite', Patent US4801488, USA, 1989. 
155. P. Van Loan: 'Conductive ternary oxides of ruthenium and their use in thick film resistor glazes', Ceramic Bulletin, 1972, 51(3), 231-233; 242.

156. M. Prudenziati and B. Morten: 'Piezoresistive properties of thick-film resistors: an overview', Microelectronics International, 1986, 3(2), 20-23; 37.

157. S. Tankiewicz, B. Morten, M. Prudenziati, and L. J. Golonka: 'New thick-film material for piezoresistive sensors', Sens. Actuat. A, 2001, 95(1), 39-45.

158. M. Coleman and G. Gurnett: 'The limitations of reactively-bonded thick film gold conductors', Solid State Technology, 1979, 22, 45-51.

159. D. E. Riemer: 'Method for making thick film gold conductor', Patent US5039552, USA, 1991.

160. H. Hara, M. H. La Branche, and B. E. Taylor: 'Silver-rich conductor compositions for high thermal cycled and aged adhesion', Patent US5250229, USA, 1993.

161. N. Pavlushkin, A. Zhuravlev, and L. Egorova: 'Change in the phase compositions of lead glasses during crystallization', Inorganic Materials, 1968, 4, 403.

162. M. Hrovat, T. Maeder, C. Jacq, J. Holc, and J. Bernard: 'Subsolidus phase equilibria in the $\mathrm{PbO}$-poor part of the $\mathrm{TiO}_{2}-\mathrm{PbO}-\mathrm{SiO}_{2}$ system and its application in low-temperature thick-film dielectrics', Journal of Materials Research, 2006, 21(12), 3210-3214.

163. L. Hoffman: 'Crystallizable dielectrics in multilayer structures for hybrid microcircuits: a review', Ceramic Substrates and Packages for Electronic Applications (Advances in Ceramics vol 26), 1989, 26, 249-253.

164. H. Birol, T. Maeder, and P. Ryser: 'Influence of processing and conduction materials on properties of co-fired resistors in LTCC structures', J. Eur. Ceram. Soc., 2006, 26(10-11), 1937-1941.

165. S. Smernos: 'Filler for a glass-ceramic material comprising $\mathrm{CaF}_{2}$ granules overcoated with a silicon dioxide film', Patent US4185139, USA, 1980.

166. R. J. Bouchard, L. T. Cheng, D. H. Roach, and P. J. Moffett: 'Screen printable dielectric for field emission displays', J. Am. Ceram. Soc., 2005, 88(6), 1465-1467.

167. C. Jacq, S. Vionnet, and T. Maeder: 'Analyse FX des diélectriques commerciaux [XRF analysis of commercial dielectrics]', EPFL, Lausanne (CH), 2004.

168. W. K. Jones, Y. Liu, B. Larsen, P. Wang, and M. Zampino: 'Chemical, structural and mechanical properties of the LTCC tapes', J. Microelectron. Electron. Pack., 2000, 23(4), $469-473$.

169. S. Nishigaki, U. Goebel, and W. Roethlingshoefer: 'LTCC (LFC) material systems and its application in automotive ECU's', IMAPS Conference, Ceramic Interconnect Technology, Denver (USA), 2004-04, 2004, WP32.

170. C. Bienert and A. Roosen: 'Characterization of material behavior of low temperature cofired ceramics at elevated temperatures', J. Eur. Ceram. Soc., 2010, 30(2), 369-374.

171. Anon: 'On the restriction of the use of certain hazardous substances in electrical and electronic equipment (RoHS)', directive 2002/95/EC of the European Parliament and of the Council, 2002.

172. F. Hua and J. Glazer: 'Lead-free solders for electronic assembly', Design \& Reliability of Solder Interconnects, proceedings, TMS symposium, 1997, 65-73.

173. Anon: 'Frequently asked questions on directive 2002/95/EC on the restriction of the use of certain hazardous substances in electrical and electronic equipment (RoHS) and directive 2002/96/EC on waste electrical and electronic equipment (WEEE)', European Commission, Directorate-General Environment, 2006.

174. R. Eppler: 'Formulation of glazes for low Pb release', Ceramic Bulletin, 1975, 54(5), 496-499. 
175. J. Graziano and C. Blum: 'Lead exposure from lead crystal', The Lancet, 1991, 337(8734), 141-142.

176. S. Barbee and L. Constantine: 'Release of lead from crystal decanters under conditions of normal use', Food and Chemical Toxicity, 1994, 32(3), 285-288.

177. F. Tack, S. Singh, and M. Verloo: 'Leaching behaviour of $\mathrm{Cd}, \mathrm{Cu}, \mathrm{Pb}$ and $\mathrm{Zn}$ in surface soils derived from dredged sediments', Environmental Pollution, 1999, 106(1), 107-114.

178. L. Rebenklau, J. Uhlemann, M. Thummler, and K. J. Wolter: 'Biological characteristics of commercial low temperature cofiring ceramics', $14^{\text {th }}$ European Microelectronics and Packaging Conference, Friedrichshafen (DE), 2003-06, 2003, IMAPS, 325-330.

179. J. Uhlemann, G. Schlottig, S. Schindler, S. Starcke, G. Vollmer, and K. Wolter: 'Evaluation of cytotoxicity of chip-on-board-materials', Proceedings, XXIX International Conference of IMAPS Poland, Koszalin, 2005, 61-68.

180. S. Achmatowicz, M. Jakubowska, J. Kalenik, R. Kisiel, A. Młozniak, and E. Zwierkowska: 'Lead-free silver based thick film pastes', Proceedings, XXVIII International Conference of IMAPS Poland Chapter, Wroclaw, 2004, 151-154.

181. J. S. Jeon, M. R. Cha, and H. S. Kim: 'Optical properties of $\mathrm{Bi}_{2} \mathrm{O}_{3}-\mathrm{ZnO}-\mathrm{SiO}_{2}$ glass system for eco transparent dielectric in PDP', Materials Science Forum, 2005, 486-487, 321-324.

182. R. Morena: 'Phosphate glasses as alternatives to Pb-based sealing frits', Journal of NonCrystalline Solids, 2000, 263-264, 382-387.

183. M. V. Coleman: 'Thick-film materials for hybrids', The Radio and Electronic Engineer, 1982, 52(5), 227-234.

184. P. Sayers and W. Petsis: 'Characteristics of nitrogen fireable materials for hybrids and multilayers', Proceedings, International Symposium on Microelectronics, Minneapolis (USA), 1987-09, 1987, ISHM, 11-18.

185. C. Y. Kuo: 'Nitrogen fireable tin oxide thick film resistor system', International Symposium on Microelectronics, Baltimore (USA), 1989-10, 1989, ISHM, 150-167.

186. T. Iseki, O. Makino, and K. Nishida: 'A new copper-compatible nitrogen firing system', Proceedings, International Symposium on Microelectronics, Baltimore (USA), ISHM, 1989, 168-174.

187. R. Tanabe and J. Chiba: 'Properties of new nitrogen fireable resistor system for thick film circuits', Proceedings, International Symposium on Microelectronics, Chicago (USA), ISHM, 1990, 92-97.

188. R. Tanabe and Y. Nishihara: 'Resistor paste and ceramic substrate', Patent US5264272, USA, 1993.

189. D. Dyshel' and K. Blank: 'Properties of resistive thick films based on powdered $\mathrm{Sn}_{0.9} \mathrm{Sb}_{0.1} \mathrm{O}_{2}$ and obtained by heat treatment in nitrogen', Powder Metallurgy and Metal Ceramics, 1995, 34(3-4), 219-222.

190. R. R. Sutherland and I. D. E. Videlo: 'A comparison of the reliability of copper and palladiumsilver thick-film crossovers', IEEE Transactions on Components, Hybrids and Manufacturing Technology, 1987, CHMT-12(4), 676-682.

191. A. Andriesh, V. Ponomar', V. Smirnov, and A. Mironos: 'Applications of chalcogenide glasses in integrated and fiber optics (review)', Soviet Journal of Quantum Electronics, 1986, 16(6), 195-204.

192. J. Lucas: 'Fluoride glasses', Journal of Materials Science, 1989, 24(1), 1-13.

193. J. M. Parker: 'Fluoride glasses', Annual Reviews of Materials Science, 1989, 19, 21-41. 
194. G. Fuxi: 'Structure, properties and applications of chalcohalide glasses: a review', Journal of Non-Crystalline Solids, 1992, 140, 184-193.

195. M. Prudenziati, F. Zanardi, B. Morten, and A. F. Gualtieri: 'Lead-free thick film resistors: an explorative investigation', Journal of Materials Science: Materials in Electronics, 2002, 13(1), 31-37.

196. S. L. Fu, C. S. Hsi, C. Y. Kang, W. H. Chin, and T. Y. Hsieh: 'Influences of additives on the electrical properties of lead-free thick film resistors', Proceedings, XXIX International Conference of IMAPS Poland, Koszalin, 2005, 19-24.

197. K. Kiełbasiński, A. Młożniak, and M. Jakubowska: 'High ohm eco-friendly resistors in thick film technology', XXXII International Conference of IMAPS Poland Chapter, Pułtusk (PL), 2008-09, 2008, B09.

198. K. Kiełbasiński, A. Młożniak, and M. Jakubowska: 'Vanadium oxide as a devitrification exhibitor in lead-free glass for environmental friendly thick film resistors', XXXIII International Conference of IMAPS Poland Chapter, Gliwice - Pszczyna (PL), 2009-09, 2009, 175-179.

199. M. Prudenziati, B. Morten, and S. B. Rane: 'Perovskite ruthenate-based lead-free thick film resistors', European Microelectronics and Packaging Symposium, Prague (CZ), 2004-06, 2004, 277-282.

200. S. B. Rane, M. Prudenziati, and B. Morten: 'Microstructure and electrical properties of perovskite ruthenate-based lead-free thick film resistors on alumina and LTCC', XXVIII International Conference of IMAPS Poland Chapter, Wroclaw (PL), 2004-09, 2004, 362-365.

201. S. B. Rane, M. Prudenziati, and B. Morten: 'Environment friendly perovskite ruthenate based thick film resistors', Materials Letters, 2007, 61(2), 595-599.

202. S. Jagtap, S. Rane, and D. Amalnerkar: 'Environmentally sustainable composite resistors with low temperature coefficient of resistance', Microelectronic Engineering, 2009, 86, 2026-2029.

203. J. Hormadaly: 'Thick film compositions containing pyrochlore-related compounds', Patent US2004-043885, USA, 2004.

204. A. I. Ermolaeva: 'Glass formation and properties of glasses in the $\mathrm{PbO}-\mathrm{ZnO}-\mathrm{B}_{2} \mathrm{O}_{3}$ system', Glass Physics and Chemistry, 1983, 27(4), 306-314.

205. J. Clinton and W. Coffeen: 'Low melting glasses in the system $\mathrm{B}_{2} \mathrm{O}_{3}-\mathrm{ZnO}-\mathrm{CaO}-\mathrm{P}_{2} \mathrm{O}_{5}$ ', Ceramic Bulletin, 1984, 63(11), 1401-1404.

206. H. Masuda, R. Kimura, N. Sakamoto, and K. Morinaga: 'Properties and structure of glasses in the system $\mathrm{BaO}_{-} \mathrm{B}_{2} \mathrm{O}_{3}-\mathrm{ZnO}$ ', Journal of the Japanese Institute of Metals, 1999, 63(3), 62846288 .

207. J. R. Kim, G. K. Choi, D. K. Yim, J. S. Park, and K. S. Hong: 'Thermal and dielectric properties of $\mathrm{ZnO}-\mathrm{B}_{2} \mathrm{O}_{3}-\mathrm{MO}_{3}$ glasses $(\mathrm{M}=\mathrm{W}$, Mo)', Journal of Electroceramics, 2006, 17(1), 65-69.

208. L. Hoffman: 'Non-toxic aluminium enamel frits', Patent US2911312, USA, 1959.

209. N. H. Ray: 'The structure and properties of inorganic polymeric phosphates', British Polymer Journal, 1979, 11(4), 163-177.

210. R. K. Brow: 'Review: the structure of simple phosphate glasses.', Journal of Non-Crystalline Solids, 2000, 263-264, 1-28.

211. P. Y. Shih and T. S. Chin: 'Preparation of lead-free phosphate glasses with low $T_{g}$ and excellent chemical durability', Journal of Materials Science Letters, 2001, 20(19), 1811-1813.

212. N. Grebenshchikova, G. Kolosenko, and E. Lisitsyna: 'Стекло [Glass]', Patent SU1768537, Russia, 1992. 
213. T. Jermoumi, M. Hafid, N. Niegisch, M. Mennig, A. Sabir, and N. Toreis: 'Properties of (0.5$x) \mathrm{ZnO}-x \mathrm{Fe}_{2} \mathrm{O}_{3}-0.5 \mathrm{P}_{2} \mathrm{O}_{5}$ glasses', Materials Research Bulletin, 2002, 37, 49-57.

214. J. Setina, V. Akishin, and J. Vaivads: 'Glass composition for the thick-film resistors', Materials Science Forum, 2005, 502, 231-236.

215. H. S. Kim and B. H. Jung: 'Application of lead-free glass to barrier rib materials in plasma display panel', Materials Science Forum, 2003, 439, 18-22.

216. J. Hormadaly: 'Lead-free phosphate glasses', Patent US2006-0128549, USA, 2006.

217. B. G. Aitken, D. C. Bookbinder, M. E. Greene, and R. M. Morena: 'Non-lead sealing glasses', Patent US5246890, USA, 1993.

218. E. Bekaert, L. Montagne, L. Delevoye, G. Palavit, and B. Revel: 'Structure and properties of $x \cdot \mathrm{SnO}-(100-x) \cdot \mathrm{P}_{2} \mathrm{O}_{5}$ glasses', Comptes Rendus de Chimie, 2004, 7(3-4), 377-382.

219. E. Popova and Y. Dimitriev: 'Tin-based amorphous and composite materials', Journal of Materials Science, 2007, 42(10), 3358-3366.

220. C. M. Shaw and J. E. Shelby: 'The effect of stannous oxide on the properties of stannous fluorophosphate glasses', Physics and Chemistry of Glasses, 1988, 29(3), 87-90.

221. K. Morinaga and S. Fujino: 'Preparation and properties of $\mathrm{SnO}_{-} \mathrm{SnCl}_{2}-\mathrm{P}_{2} \mathrm{O}_{5}$ glass', Journal of Non-Crystalline Solids, 2001, 282(1), 118-124.

222. T. Kikutani: 'Sealing material', Patent JP2001-019472, Japan, 2001.

223. H. Masuda: 'Lead-free low softening point glass', Patent US2006/0052230, USA, 2006.

224. N. F. Mott: 'Conduction in glasses containing transition metal ions', Journal of NonCrystalline Solids, 1968, 1(1), 1-17.

225. M. Sayer and A. Mansingh: 'Transport properties of semiconducting phosphate glasses', Physical Review B, 1972, 6(12), 4629-4643.

226. L. Murawski and R. J. Barczynski: 'Dielectric properties of transition metal oxide glasses', Journal of Non-Crystalline Solids, 1995, 185(1-2), 84-93.

227. X. Fang, C. S. Ray, A. Moguš-Milanković, and D. E. Day: 'Iron redox equilibrium, structure and properties of iron phosphate glasses', Journal of Non-Crystalline Solids, 2001, 282(1-3), 162-172.

228. A. Moguš-Milanković, A. Šantič, V. Ličina, and D. E. Day: 'Dielectric behavior and impedance spectroscopy of bismuth iron phosphate glasses', Journal of Non-Crystalline Solids, 2005, 351, 3235-3245.

229. B. A. Rajnikant and L. C. Hoffman: 'Air fireable compositions containing vanadium oxide and boron, and devices therefrom', Patent US3622523, 1969.

230. M. E. Dumesnil, R. E. Hewitt, and J. L. Bozarth: 'Low-expansion, low-melting zinc phosphovanadate glass compositions', Patent US3650778, USA, 1972.

231. V. Dimitrov, Y. Dimitriev, and A. Montenero: 'IR spectra and structure of $\mathrm{V}_{2} \mathrm{O}_{5}-\mathrm{GeO}_{2}-\mathrm{Bi}_{2} \mathrm{O}_{3}$ glasses', Journal of Non-Crystalline Solids, 1994, 180(1), 51-57.

232. R. Iordanova, V. Dimitrov, Y. Dimitriev, and D. Klissurski: 'Glass formation and structure of glasses in the $\mathrm{V}_{2} \mathrm{O}_{5}-\mathrm{MoO}_{3}-\mathrm{Bi}_{2} \mathrm{O}_{3}$ system', Journal of Non-Crystalline Solids, 1994, 180(1), 58 65.

233. R. Iordanova, Y. Dimitriev, V. Dimitrov, S. Kassabov, and D. Klissurski: 'Glass formation and structure in the $\mathrm{V}_{2} \mathrm{O}_{5}-\mathrm{Bi}_{2} \mathrm{O}_{3}-\mathrm{Fe}_{2} \mathrm{O}_{3}$ glasses', Journal of Non-Crystalline Solids, 1996, 204(2), 141-150. 
234. R. Iordanova, Y. Dimitriev, V. Dimitrov, S. Kassabov, and D. Klissurski: 'Glass formation and structure in the system $\mathrm{MoO}_{3}-\mathrm{Bi}_{2} \mathrm{O}_{3}-\mathrm{Fe}_{2} \mathrm{O}_{3}{ }^{\prime}$, Journal of Non-Crystalline Solids, 1998, 231, 227-233.

235. R. Iordanova, E. Lefterova, I. Uzunov, Y. Dimitriev, and D. Klissurski: 'Non-isothermal crystallization kinetics of $\mathrm{V}_{2} \mathrm{O}_{5}-\mathrm{MoO}_{3}-\mathrm{Bi}_{2} \mathrm{O}_{3}$ glasses', Journal of Thermal Analysis and Calorimetry, 2002, 70(2), 393-404.

236. B. G. Aitken and M. J. Dejneka: 'Tungstate, molybdate, vanadate base glasses', Patent US6376399, USA, 2002.

237. R. A. H. El-Mallawany: 'Tellurite Glasses Handbook - Physical Properties and Data'; 2002,

238. A. Basu, J. M. Lewis, P. O’Biren, H. Feller, S. R. Starns, J. Fruch, S. A. Feller, and M. Affatigato: 'Glass formation, molar volumes and glass transition temperatures of binary vanadate glasses', Physics and Chemistry of Glasses, 2003, 44(1), 1-4.

239. V. Rajendran, N. Palanivelu, B. K. Chaudhuri, and K. Goswami: 'Characterisation of semiconducting $\mathrm{V}_{2} \mathrm{O}_{5}-\mathrm{Bi}_{2} \mathrm{O}_{3}-\mathrm{TeO}_{2}$ glasses through ultrasonic measurements', Journal of NonCrystalline Solids, 2003, 320(1-3), 195-209.

240. M. Udovic, P. Thomas, A. Mirgorodsky, O. Durand, M. Soulis, O. Masson, T. Merle-Méjean, and J. C. Champarnaud-Mesjard: 'Thermal characteristics, Raman spectra and structural properties of new tellurite glasses within the $\mathrm{Bi}_{2} \mathrm{O}_{3}-\mathrm{TiO}_{2}-\mathrm{TeO}_{2}$ system', Journal of Solid State Chemistry, 2006, 179(10), 3252-3259.

241. E. Yousef, M. Hotzel, and C. Rüssel: 'Effect of $\mathrm{ZnO}$ and $\mathrm{Bi}_{2} \mathrm{O}_{3}$ addition on linear and nonlinear optical properties of tellurite glasses', Journal of Non-Crystalline Solids, 2007, 353(4), 333-338.

242. K. Snowdon: 'Sealing glass composition', Patent EP1391437, Europe, 2004.

243. M. Fukaya, T. Matsuo, S. Nishigaki, and C. Higuchi: 'Highly reliable and lead $(\mathrm{Pb})$ free thick film resistor paste system for low thermal expansion LTCC application', 1997 International Symposium on Microelectronics, Philadelphia (USA), 1997-10, 1997, IMAPS, 65-71.

244. M. S. R. Heynes and H. Rawson: 'Bismuth trioxide glasses', Journal of the Society of Glass Technology, 1957, 41, 347-349.

245. M. Imaoka: 'Glass-formation and glass structure', Proceedings, International Congress on Glass, Brussels, BE, 1965, 7, 149-164.

246. B. V. Janakirama-Rao: 'Unusual properties and structure of glasses in the systems $\mathrm{Bi}_{2} \mathrm{O}_{3}-\mathrm{B}_{2} \mathrm{O}_{3^{-}}$ $\mathrm{SrO} ; \mathrm{Bi}_{2} \mathrm{O}_{3}-\mathrm{B}_{2} \mathrm{O}_{3}-\mathrm{BaO} ; \mathrm{Bi}_{2} \mathrm{O}_{3}-\mathrm{B}_{2} \mathrm{O}_{3}-\mathrm{ZnO}$ and $\mathrm{Bi}_{2} \mathrm{O}_{3}-\mathrm{B}_{2} \mathrm{O}_{3}-\mathrm{PbO}$ ', $7^{\text {th }}$ International Congress on Glass, Brussels (BE), 1965-00, 1965, Gordon \& Breach, New York (USA), 104.101-104.106.

247. A. M. Bishay and C. Maghrabi: 'Properties of bismuth glasses in relation to structure', Physics and Chemistry of Glasses, 1969, 10(10), 1-11.

248. H. B. George, C. Vira, C. Stehle, J. Meyer, S. Evers, D. Hogan, S. Feller, and M. Affatigato: 'A structural analysis of the physical properties of bismuth and lead based glasses', Physics and Chemistry of Glasses, 1999, 40(6), 326-332.

249. N. S. Shuster, F. A. Novruzova, C. L. K. Zeinalova, and M. I. Zargarova: 'Стеклообразование и физико-чемические своиства стекол системьи $\mathrm{CuO}-\mathrm{Bi}_{2} \mathrm{O}_{3}-\mathrm{B}_{2} \mathrm{O}_{3}$ [Glass forming and physico-chemical properties of glasses in the system $\mathrm{CuO}-\mathrm{Bi}_{2} \mathrm{O}_{3}-\mathrm{B}_{2} \mathrm{O}_{3}$ ]', Fizika i Chimija Stekla, 1990, 16(2), 197-200.

250. J. Hormadaly: 'Cadmium-free and lead-free thick film conductor composition', Patent US5439852, USA, 1995.

251. J. Hormadaly: 'Cadmium-free and lead-free thick film paste composition', Patent US5491118, USA, 1996. 
252. H. H. Qiu, T. Ito, and H. Sakata: 'DC conductivity of $\mathrm{Fe}_{2} \mathrm{O}_{3}-\mathrm{Bi}_{2} \mathrm{O}_{3}-\mathrm{B}_{2} \mathrm{O}_{3}$ glasses', Materials Chemistry and Physics, 1999, 58, 243-248.

253. T. Watanabe, K. Muratsubaki, Y. Benino, H. Saitoh, and T. Komatsu: 'Hardness and elastic properties of $\mathrm{Bi}_{2} \mathrm{O}_{3}$-based glasses', Journal of Materials Science, 2001, 36(10), 2427-2433.

254. F. El Batal, M. Azooz, and F. Ezz-Eldin: 'Thermal expansion and infrared studies of binary $\mathrm{Bi}_{2} \mathrm{O}_{3}-\mathrm{B}_{2} \mathrm{O}_{3}$ and ternary $\mathrm{Bi}_{2} \mathrm{O}_{3}-\mathrm{B}_{2} \mathrm{O}_{3}-\mathrm{PbO}$ glasses', Physics and Chemistry of Glasses, 2002, 43(5), 260-266.

255. L. Baia, R. Stefan, J. Popp, S. Simon, and W. Kiefer: 'Vibrational spectroscopy of highly iron doped $\mathrm{B}_{2} \mathrm{O}_{3}-\mathrm{Bi}_{2} \mathrm{O}_{3}$ glass systems', Journal of Non-Crystalline Solids, 2003, 324(1-2), 109117.

256. G. Rachkovskaya and G. Zakharevich: 'Properties, structure, and application of low-melting lead-bismuth glasses', Glass and Ceramics, 2004, 61(1-2), 9-12.

257. I. Dyamant, D. Itzhak, and J. Hormadaly: 'Thermal properties and glass formation in the $\mathrm{SiO}_{2}-$ $\mathrm{B}_{2} \mathrm{O}_{3}-\mathrm{Bi}_{2} \mathrm{O}_{3}-\mathrm{ZnO}$ quaternary system', Journal of Non-Crystalline Solids, 2005, 351(43-45), 3503-3507.

258. S. Sindhu, S. Sanghi, A. Agarwal, V. P. Seth, and N. Kishore: 'Effect of $\mathrm{Bi}_{2} \mathrm{O}_{3}$ content on the optical band gap, density and electrical conductivity of $\mathrm{MO} \cdot \mathrm{Bi}_{2} \mathrm{O}_{3} \cdot \mathrm{B}_{2} \mathrm{O}_{3}(\mathrm{M}=\mathrm{Ba}, \mathrm{Sr})$ glasses', Materials Chemistry and Physics, 2005, 90(1), 83-89.

259. M. Hamezan, H. A. A. Sidek, A. W. Zaidan, K. Kaida, and A. T. Zainal: 'Elastic constants and thermal properties of lead-bismuth borate glasses', Journal of Applied Sciences, 2006, 6(4), 943-949.

260. Y. J. Kim, S. J. Hwang, and H. S. Kim: 'Thermal properties of $\mathrm{Bi}_{2} \mathrm{O}_{3}-\mathrm{B}_{2} \mathrm{O}_{3}-\mathrm{ZnO}$ glass system', Materials Science Forum, 2006, 510-511, 578-581.

261. S. Aziz, A. Hamezan, A. Zaidan, A. Zainal, A. Zainal, A. Shaari, and H. Senin: 'Ultrasonic and thermal properties of borate and phosphate glasses containing bismuth and lead', AIP Conference Proceedings, 2007, 909, 197-209.

262. J. Jirák, L. Koudelka, J. Pospíšil, P. Mošner, L. Montagne, and L. Delevoye: 'Study of structure and properties of $\mathrm{ZnO}-\mathrm{Bi}_{2} \mathrm{O}_{3}-\mathrm{P}_{2} \mathrm{O}_{5}$ glasses', Journal of Materials Science, 2007, 42(20), 8592-8598.

263. B. S. Kim, E. S. Lim, J. H. Lee, and J. J. Kim: 'Effect of $\mathrm{Bi}_{2} \mathrm{O}_{3}$ content on sintering and crystallization behavior of low-temperature firing $\mathrm{Bi}_{2} \mathrm{O}_{3}-\mathrm{B}_{2} \mathrm{O}_{3}-\mathrm{SiO}_{2}$ glasses', J. Eur. Ceram. Soc., 2007, 27(2-3), 819-824.

264. D. Saritha, Y. Markandeya, M. Salagram, M. Vithal, A. K. Singh, and G. Bhikshamaiah: 'Effect of $\mathrm{Bi}_{2} \mathrm{O}_{3}$ on physical, optical and structural studies of $\mathrm{ZnO}-\mathrm{Bi}_{2} \mathrm{O}_{3}-\mathrm{B}_{2} \mathrm{O}_{3}$ glasses', Journal of Non-Crystalline Solids, 2008, 354(52-54), 5573-5579.

265. Y. H. Na, N. J. Kim, S. H. Im, J. M. Cha, and B. K. Ryu: 'Effect of $\mathrm{Bi}_{2} \mathrm{O}_{3}$ on structure and properties of zinc bismuth phosphate glass', Journal of the Ceramic Society of Japan, 2009, 117(1371), 1273-1276.

266. H. Doweidar and Y. B. Saddeek: 'FTIR and ultrasonic investigations on modified bismuth borate glasses', Journal of Non-Crystalline Solids, 2009, 355, 348-354.

267. S. Im, Y. Na, N. Kim, D. Kim, C. Hwang, and B. Ryu: 'Structure and properties of zinc bismuth phosphate glass', Thin Solid Films, 2010, 518(24S1), e46-e49.

268. H. Y. Koo, J. H. Yi, and Y. C. Kang: 'Characteristics of Bi-based glass powders with various glass transition temperatures prepared by spray pyrolysis', Ceramics International, 2010, 36(5), 1749-1753.

269. K. Majhi and K. B. R. Varma: 'Dielectric relaxation in $\mathrm{CaO}-\mathrm{Bi}_{2} \mathrm{O}_{3}-\mathrm{B}_{2} \mathrm{O}_{3}$ Glasses', Physics and Chemistry of Glasses, 2010, 7(S1), E89-E97. 
270. M. R. Oganesyan, R. M. Oganesyan, and N. B. Knyazyan: 'Interrelation between glass formation, liquidus temperature, and the cooling rate of barium-bismuth-borate melts', Theoretical Foundations of Chemical Engineering, 2010, 44(4), 500-502.

271. W. Qiao and P. Chen: 'Study on the properties of $\mathrm{Bi}_{2} \mathrm{O}_{3}-\mathrm{B}_{2} \mathrm{O}_{3}-\mathrm{BaO}$ lead-free glass using in the electronic pastes', Glass Physics and Chemistry, 2010,36(3), 1956-1960.

272. M. Shapaan and F. Ebrahima: 'Structural and electric-dielectric properties of $\mathrm{B}_{2} \mathrm{O}_{3}-\mathrm{Bi}_{2} \mathrm{O}_{3}-$ $\mathrm{Fe}_{2} \mathrm{O}_{3}$ oxide glasses', Physica B, 2010, 405(16), 3217-3222.

273. T. Honma, Y. Benino, T. Fujiwara, T. Komatsu, and R. Sato: 'Crystalline phases and YAG laser-induced crystallization in $\mathrm{Sm}_{2} \mathrm{O}_{3}-\mathrm{Bi}_{2} \mathrm{O}_{3}-\mathrm{B}_{2} \mathrm{O}_{3}$ glasses', J. Am. Ceram. Soc., 2005, 88(4), 989-992.

274. S. Simon and D. Eniu: 'Spectroscopic characterisation of local structure in $\mathrm{Y}_{2} \mathrm{O}_{3}-\mathrm{B}_{2} \mathrm{O}_{3}-\mathrm{Bi}_{2} \mathrm{O}_{3}$ glasses doped with gadolinium', Journal of Materials Science, 2007, 42(15), 5949-5953.

275. Y. Cheng, H. Xiao, and W. Guo: 'Influences of $\mathrm{La}^{3+}$ and $\mathrm{Er}^{3+}$ on structure and properties of $\mathrm{Bi}_{2} \mathrm{O}_{3}-\mathrm{B}_{2} \mathrm{O}_{3}$ glass', Ceramics International, 2008, 34(5), 1335-1339.

276. P. Pascuta, G. Borodi, and E. Culea: 'Influence of europium ions on structure and crystallization properties of bismuth borate glasses and glass ceramics', Journal of NonCrystalline Solids, 2008, 354(52-54), 5475-5479.

277. P. Pascuta, S. Rada, G. Borodi, M. Bosca, L. Pop, and E. Culea: 'Influence of europium ions on structure and crystallization properties of bismuth-alumino-borate glasses and glass ceramics', Journal of Molecular Structure, 2009, 924-926, 214-220.

278. S. Rada, M. Culea, M. Rada, P. Pascuta, V. Matles, and E. Culea: 'The double role played by the $\mathrm{Gd}_{2} \mathrm{O}_{3}$ in the gadolinium-aluminum-borate-bismuthate quaternary glass forming tendency. $\mathrm{GdBO}_{3}$ crystalline phase', Journal of Molecular Structure, 2009, 937, 70-74.

279. M. I. Zargarova and N. S. Shuster: 'Projection of the liquidus surface for the system $\mathrm{PbO}-$ $\mathrm{Bi}_{2} \mathrm{O}_{3}-\mathrm{B}_{2} \mathrm{O}_{3}$ system', Inorganic Materials, 1993, 29(4), 540-544.

280. V. P. Zhereb and V. M. Skorikov: 'Metastable states in bismuth-containing oxide systems', Inorganic Materials, 2003, 39(S2), S121-S145.

281. Y. T. Fei, S. J. Fan, R. Y. Sun, J. Y. Xu, and M. Ishii: 'Crystallizing behavior of $\mathrm{Bi}_{2} \mathrm{O}_{3}-\mathrm{SiO}_{2}$ system', Journal of Materials Science Letters, 2000, 19(11), 893-895.

282. Y. F. Kargin, V. P. Zhereb, and A. V. Egorysheva: 'Metastable phase diagram for the $\mathrm{Bi}_{2} \mathrm{O}_{3^{-}}$ $\mathrm{B}_{2} \mathrm{O}_{3}$ system', Russian Journal of Inorganic Chemistry, 2002, 47(8), 1240-1242.

283. J. J. Knox: 'Vitrifiable flux and bonding composition containing same', Patent US2385580, USA, 1945.

284. O. A. Short: 'Vitrifiable flux and silver compositions containing same', Patent US2819170, USA, 1958.

285. M. E. Dumesnil: 'Vitrifiable inorganic ceramic binder and silver compositions containing the same', Patent US2942992, USA, 1960.

286. J. H. Martin: 'Ceramic with metal film via binder of copper oxide containing glass', Patent, 1966-12, 1966.

287. L. Hoffman: 'Metallizing compositions containing bismuthate glass-ceramic conductor binder', Patent US3741780, USA, 1973.

288. B. E. Taylor: 'Binder glass of $\mathrm{Bi}_{2} \mathrm{O}_{3}-\mathrm{SiO}_{2}-\mathrm{GeO}_{2}$ (-PbO optional) admixed with $\mathrm{ZnO} / \mathrm{ZnO}$ and $\mathrm{Bi}_{2} \mathrm{O}_{3}{ }^{\prime}$, Patent US4567151, USA, 1986.

289. N. N. Ermolenko, Z. F. Manchenko, V. N. Samujlova, and V. Shamkalovich: 'Легкоплавкое стекло [Low-melting glass]', Patent SU775061, USSR, 1980. 
290. N. N. Ermolenko, Z. F. Manchenko, N. G. Saevich, V. N. Samujlova, V. M. Grigorev, V. M. Ivolgin, and R. A. Titova: 'Легкоплавкое стекло [Low-melting glass]', Patent SU923'976, USSR, 1982.

291. N. N. Ermolenko, E. M. Diatlova, and L. N. Martinova: 'Легкоплавкое стекло [Low-melting glass]', Patent SU947102, USSR, 1982.

292. N. N. Ermolenko, Z. F. Manchenko, E. F. Karpovich, I. A. Tikhonov, N. G. Saevich, L. I. Panov, and B. R. Sokolovskii: 'Стекло [Glass]', Patent SU1169951, USSR, 1985.

293. I. Tikhonov, N. Ermolenko, Z. Manchenko, N. Saevich, and I. Savelov: 'Легкоплавкое стекло [Low-melting glass]', Patent SU1'477'706, USSR, 1989.

294. G. M. Matveev and G. G. Zainullin: 'New glass systems and the development of glasses based on them', Glass and Ceramics, 1980, 37(4), 211-213.

295. J. Francel: 'Chemical resistant lead-free glass frit composition', Patent US4554258, USA, 1985.

296. B. P. Reinherz: 'Lead-free glass frit compositions', Patent US4892847, USA, 1990.

297. M. Wada and H. Toru: 'Glass compound for overcoat or sealing of transparent electrode', Patent JP05-165042, Japan, 1993-06, 1993.

298. R. Prunchak: 'High bismuth oxide based flux and paint compositions for glass substrates', Patent US5629247, USA, 1997.

299. G. E. Sakoske: 'Niedrig schmelzende, bleifreie Glas- und Emailzusammensetzungen mit hohem Bismutgehalt [low-melting, lead-free glass and glaze compositions with high bismuth content]', Patent EP0955274, Europe, 2000.

300. G. E. Sakoske: 'Bleifreie, alkalimetallfreie Glaszusammensetzungen [Lead-free and alkalimetal-free glass compositions]', Patent EP1006088, Europe, 2000-06, 2000.

301. S. Sridharan, R. P. Blonski, H. Emlemdi, G. J. Roberts, and I. H. Joyce: 'Glass enamel for automotive applications', Patent WO00-41977, Int1., 2000.

302. S. Sridharan and M. Moroz: 'Electronic device having lead and cadmium free electronic overglaze applied thereto', Patent US7740899, USA, 2010.

303. A. F. Carroll and K. W. Hang: 'Lead-free thick film paste composition', Patent US5378408, USA, 1995-01, 1995.

304. A. F. Carroll and K. W. Hang: 'Lead-free thick film paste composition', Patent US5468695, USA, 1995.

305. T. Fujii and T. Neyagawa: 'Electrode material, dielectric material and plasma display panel using them', Patent US6787239, USA, 2004.

306. J. Hormadaly and B. E. Taylor: 'Encapsulant composition', Patent US5137851, USA, 1992.

307. P. C. Donohue: 'Lead and cadmium-free encapsulant composition', Patent EP0858973, Europe, 1999-12, 1999.

308. N. Hayakawa and T. Shimooka: 'Lead-free low-melting glass', Patent EP1361199, Europe, 2003.

309. T. Sanada: 'Electroconductive composition for glass substrate and anti-fog window glass for automobiles', Patent USA6787239, USA, 1999.

310. T. Miki and A. Maeda: 'Conductive paste and ceramic electronic component', Patent, 2003-07, 2003.

311. H. Usui, T. Manabe, K. Harada, and R. Tanabe: 'Hermetic sealing composition', Patent US5733828, USA, 1998. 
312. B. Nachmansohn: 'Verre de soudure à dévitrification sans plomb ni autres matériaux toxiques [Devitrifying solder glass without lead or other toxic materials]', Patent FR2794120, France, 2000.

313. S. Hasegawa, M. Kanai, H. Torii, and T. Kamimoto: 'Glass composition, sealing glass for magnetic head and magnetic head', Patent European Patent 1'291'329, Europe, 2003.

314. S. Hasegawa, H. Onishi, M. Kanai, and T. Kamimoto: 'Bismuth glass composition, and magnetic head and plasma display panel including the same as sealing member', Patent US2005-0181927, USA, 2005.

315. S. V. Nemilov, O. N. Burunova, and I. S. Gilev: 'Viscosity and elasticity of glasses in the system $\mathrm{Bi}_{2} \mathrm{O}_{3}-\mathrm{B}_{2} \mathrm{O}_{3}{ }^{\prime}$, Journal of Applied Chemistry of the USSR, 1972, 45(6), 1234-1239.

316. L. Dimesso, G. Gnappi, A. Montenero, D. Fiorani, and L. D. Pye: 'Crystallization of Bi-ZnFe-B-O glasses', Journal of Non-Crystalline Solids, 1989, 112(1-3), 191-197.

317. A. Bajaj, A. Khanna, B. Chen, J. G. Longstaffe, U. W. Zwanziger, J. W. Zwanziger, Y. Gómez, and F. González: 'Structural investigation of bismuth borate glasses and crystalline phases', Journal of Non-Crystalline Solids, 2009, 355(1), 45-54.

318. P. Becker: 'Thermal and optical properties of glasses of the system $\mathrm{Bi}_{2} \mathrm{O}_{3}-\mathrm{B}_{2} \mathrm{O}_{3}$ ', Crystal Research and Technology, 2003, 38(1), 74-82.

319. B. Kusz, K. Trzebiatowski, and R. J. Barczynski: 'Ionic conductivity of bismuth silicate and bismuth germanate glasses', Solid State Ionics, 2003, 159(3-4), 293-299.

320. S. J. Hwang, S. W. Lee, and H. S. Kim: 'Sintering behavior of silver conductive thick film with frit in information display', Journal of Electroceramics, 2008, 23(2-4), 351-355.

321. J. Hormadaly: 'Cadmium-free and lead-free glass compositions, thick film formulations containing them and uses thereof', Patent US6171987, USA, 2001.

322. M. G. Busana, M. Prudenziati, and J. Hormadaly: 'Microstructure development and electrical properties of $\mathrm{RuO}_{2}$-based lead-free thick film resistors', Journal of Materials Science: Materials in Electronics, 2006, 17(11), 951-962.

323. C. Jacq, T. Maeder, and P. Ryser: 'Development of low-firing lead-free thick-film materials on steel alloys for piezoresistive sensor applications', 17th IMAPS European Microelectronics \& Packaging Conference (EMPC), Rimini (IT), 2009-06, 2009, P07.

324. C. Hirayama and E. C. Subbarao: 'Dielectric properties of bismuth borate glasses', Physics and Chemistry of Glasses, 1962, 3(4), 111-115.

325. M. B. Saisudha, K. S. R. Koteswara Rao, H. L. Bhat, and J. Ramakrishna: 'The fluorescence of $\mathrm{Nd}^{3+}$ in lead borate and bismuth borate glasses with large stimulated emission cross section', Journal of Applied Physics, 1996, 80(9), 4845-4853.

326. Y. Cheng, H. Xiao, W. Guo, and W. Guo: 'Structure and crystallization kinetics of $\mathrm{Bi}_{2} \mathrm{O}_{3}-\mathrm{B}_{2} \mathrm{O}_{3}$ glasses', Thermochimica Acta, 2006, 444(2), 173-178.

327. V. Dimitrov and T. Komatsu: 'Average single bond strength and optical basicity of $\mathrm{Bi}_{2} \mathrm{O}_{3}-$ $\mathrm{B}_{2} \mathrm{O}_{3}$ and $\mathrm{Sb}_{2} \mathrm{O}_{3}-\mathrm{B}_{2} \mathrm{O}_{3}$ glasses', Journal of Non-Crystalline Solids, 2010, 356(4-5), 258-262.

328. S. P. Yawale and S. V. Pakade: 'D.c. conductivity and hopping mechanism in $\mathrm{Bi}_{2} \mathrm{O}_{3}-\mathrm{B}_{2} \mathrm{O}_{3}$ glasses', Journal of Materials Science, 1993, 28(20), 5451-5455.

329. V. Dimitrov and T. Komatsu: 'Electronic polarizability, optical basicity and non-linear optical properties of oxide glasses', Journal of Non-Crystalline Solids, 1999, 249(2-3), 160-179.

330. I. Oprea, H. Hesse, and K. Betzler: 'Optical properties of bismuth borate glasses', Optical Materials, 2004, 26, 235-237.

331. I. Oprea: 'Optical properties of borate glass-ceramics', PhD thesis, Universität Osnabrück, Osnabrück, 2005. 
332. Y. Watanabe, S. I. Sakata, T. Watanabe, and T. Tsuchiya: 'Two-photon absorption in binary $\mathrm{Bi}_{2} \mathrm{O}_{3}-\mathrm{B}_{2} \mathrm{O}_{3}$ glass at $532 \mathrm{~nm}$ ', Journal of Non-Crystalline Solids, 1998, 240(1-3), 212-220.

333. K. Kirdsiri, J. Kaewkhao, W. Chewpraditkul, and P. Limsuwan: 'Photon interaction in borate glass system containing $\mathrm{Bi}_{2} \mathrm{O}_{3}, \mathrm{PbO}$ and $\mathrm{BaO}$ at $60 \mathrm{keV}$ : theoretical calculation', Advanced Materials Research, 2010, 93-94, 9-12.

334. M. El Sayed, Y. B. Saddeek, and E. R. Shaaban: 'Structural and optical properties of lithium borobismuthate glasses', Journal of Physics and Chemistry of Solids, 2008, 69(9), 2281-2287.

335. Y. B. Saddeek, E. R. Shaaban, M. El Sayed, and M. M. Hesham: 'Spectroscopic properties, electronic polarizability, and optical basicity of $\mathrm{Bi}_{2} \mathrm{O}_{3}-\mathrm{Li}_{2} \mathrm{O}-\mathrm{B}_{2} \mathrm{O}_{3}$ glasses', Physica $B, 2008$, 403(13-16), 2399-2407.

336. M. Subhadra and P. Kistaiah: 'Characterization and optical absorption studies of $\mathrm{VO}_{2}^{+}: \mathrm{Li}_{2} \mathrm{O}-$ $\mathrm{K}_{2} \mathrm{O}-\mathrm{Bi}_{2} \mathrm{O}_{3}-\mathrm{B}_{2} \mathrm{O}_{3}$ glass system', Journal of Alloys and Compounds, 2010, 505, 634-639.

337. S. Bale and S. Rahman: 'Glass structure and transport properties of $\mathrm{Li}_{2} \mathrm{O}$ containing zinc bismuthate glasses', Optical Materials, 2008, 31(2), 333-337.

338. S. Rani, S. Sanghi, A. Anshu, A. Agarwal, N. Kishore, and V. P. Seth: 'Effect of ZnO/CdO on the structure and electrical conductivity in $\mathrm{Li}_{2} \mathrm{O} \cdot \mathrm{MO} \cdot \mathrm{Bi}_{2} \mathrm{O}_{3} \cdot \mathrm{B}_{2} \mathrm{O}_{3}$ glasses $(\mathrm{M}=\mathrm{Zn}, \mathrm{Cd})^{\prime}$, Journal of Physics and Chemistry of Solids, 2008, 69(7), 1855-1860.

339. A. Al Hajry, A. A. Soliman, and M. M. El Desoky: 'Electrical and thermal properties of semiconducting $\mathrm{Fe}_{2} \mathrm{O}_{3}-\mathrm{Bi}_{2} \mathrm{O}_{3}-\mathrm{Na}_{2} \mathrm{~B}_{4} \mathrm{O}_{7}$ glasses', Thermochimica Acta, 2005, 427(1-2), 181186.

340. Y. B. Saddeek, K. A. Aly, A. Dahshan, and I. M. El Kashef: 'Optical properties of the $\mathrm{Na}_{2} \mathrm{O}-$ $\mathrm{B}_{2} \mathrm{O}_{3}-\mathrm{Bi}_{2} \mathrm{O}_{3}-\mathrm{MoO}_{3}$ glasses', Journal of Alloys and Compounds, 2010, 494(1-2), 210-213.

341. M. M. El Desoky, N. M. Tashtoush, and H. Habib: 'Characterization and electrical properties of semiconducting $\mathrm{Fe}_{2} \mathrm{O}_{3}-\mathrm{Bi}_{2} \mathrm{O}_{3}-\mathrm{K}_{2} \mathrm{~B}_{4} \mathrm{O}_{7}$ glasses', Journal of Materials Science: Materials in Electronics, 2005, 16(8), 533-539.

342. M. M. El Desoky and A. Al Shahrani: 'Variable-range hopping in $\mathrm{Fe}_{2} \mathrm{O}_{3}-\mathrm{Bi}_{2} \mathrm{O}_{3}-\mathrm{K}_{2} \mathrm{~B}_{4} \mathrm{O}_{7}$ glasses', Journal of Materials Science: Materials in Electronics, 2005, 16(4), 221-224.

343. M. M. El Desoky and A. Al Shahrani: 'Iron doping of semiconducting bismuth alkali borate glasses', Physica B, 2006, 383(2), 163-170.

344. Y. F. Kargin, S. N. Ivicheva, and L. I. Shvorneva: 'Phase relations in the $\mathrm{MgO}-\mathrm{Bi}_{2} \mathrm{O}_{3}-\mathrm{Bi}_{2} \mathrm{O}_{3}$ system', Russian Journal of Inorganic Chemistry, 2008, 53(8), 1297-1299.

345. Y. F. Kargin, S. N. Ivicheva, L. I. Shvorneva, M. G. Komova, and V. A. Krut'ko: 'Phase relations in the $\mathrm{CaO}-\mathrm{Bi}_{2} \mathrm{O}_{3}-\mathrm{B}_{2} \mathrm{O}_{3}$ system in the subsolidus region', Russian Journal of Inorganic Chemistry, 2008, 53(9), 1512-1516.

346. Y. F. Kargin, S. N. Ivicheva, M. G. Komova, and V. A. Krut'ko: 'Phase relations in the solidus region of the $\mathrm{SrO}-\mathrm{Bi}_{2} \mathrm{O}_{3}-\mathrm{B}_{2} \mathrm{O}_{3}$ system', Russian Journal of Inorganic Chemistry, 2008, 53(3), 474-478.

347. A. V. Egorysheva, V. M. Skorikov, V. D. Volodin, O. E. Myslitskii, and Y. F. Kargin: 'Phase equilibria in the $\mathrm{BaO}-\mathrm{Bi}_{2} \mathrm{O}_{3}-\mathrm{B}_{2} \mathrm{O}_{3}$ system', Russian Journal of Inorganic Chemistry, 2006, 51(12), 1956-1960.

348. A. V. Egorysheva and Y. F. Kargin: 'Phase equilibria in the $\mathrm{Bi}_{2} \mathrm{O}_{3}-\mathrm{BaB}_{2} \mathrm{O}_{4}-\mathrm{B}_{2} \mathrm{O}_{3}$ system in the subsolidus region', Russian Journal of Inorganic Chemistry, 2006, 51(7), 1106-1110.

349. A. V. Egorysheva, V. D. Volodin, and V. M. Skorikov: 'Glass formation in the $\mathrm{Bi}_{2} \mathrm{O}_{3}-\mathrm{B}_{2} \mathrm{O}_{3}-$ $\mathrm{BaO}$ system', Inorganic Materials, 2008, 44(11), 1261-1265. 
350. L. Tichý, H. Tichá, L. Herzigová, and J. Ozdanova: 'Some physical properties of $\left(\mathrm{Bi}_{2} \mathrm{O}_{3}\right)_{\mathrm{x}}(\mathrm{BaO})_{0.5-\mathrm{x}}\left(\mathrm{B}_{2} \mathrm{O}_{3}\right)_{0.5}$ glasses', Materials Chemistry and Physics, 2011, 126(1-2), 289294.

351. J. Barbier, N. Penin, A. Denoyer, and L. M. D. Cranswick: 'BaBiBO centrosymmetric borate oxide', Solid State Sciences, 2005, 7(9), 1055-1061.

352. K. Kotková, H. Tichá, and L. Tichý: 'Raman studies and optical properties of some $(\mathrm{PbO})_{\mathrm{x}}\left(\mathrm{Bi}_{2} \mathrm{O}_{3}\right)_{0.2}\left(\mathrm{~B}_{2} \mathrm{O}_{3}\right)_{0.8-\mathrm{x}}$ glasses', Journal of Raman Spectroscopy, 2008, 39(9), 1219-1226.

353. M. Peng, Z. Cordt, and L. Wondraczek: 'Origin of broad NIR photoluminescence in bismuthate glass and Bi-doped glasses at room temperature', Journal of Physics: Condensed Matter, 2009, 21(28), 285106.

354. M. I. Zargarova and M. F. Kasumova: 'Projection of the liquidus surface of the $\mathrm{ZnO}-\mathrm{Bi}_{2} \mathrm{O}_{3}$ $\mathrm{B}_{2} \mathrm{O}_{3}$ system', Inorganic Materials, 1990, 26(8), 1427-1430.

355. B. S. Kim, E. S. Lim, J. H. Lee, and J. J. Kim: 'Effect of structure change on thermal and dielectric characteristics in low-temperature firing $\mathrm{Bi}_{2} \mathrm{O}_{3}-\mathrm{B}_{2} \mathrm{O}_{3}-\mathrm{ZnO}$ glasses', Journal of Materials Science, 2007, 42(12), 4260-4264.

356. M. I. Zargarova, N. M. Mustafaev, and N. S. Shuster: 'CuO - $\mathrm{Bi}_{2} \mathrm{O}_{3}-\mathrm{B}_{2} \mathrm{O}_{3}$ system', Inorganic Materials, 1996, 32(1), 65-70.

357. P. Pascuta, L. Pop, S. Rada, M. Bosca, and E. Culea: 'The local structure of bismuth borate glasses doped with europium ions evidenced by FT-IR spectroscopy', Journal of Materials Science: Materials in Electronics, 2008, 19(5), 424-428.

358. Y. B. Saddeek, I. S. Yahia, K. A. Aly, and W. Dobrowolsky: 'Spectroscopic, mechanical and magnetic characterization of some bismuth borate glasses containing gadolinium ions', Solid State Sciences, 2010, 12(8), 1426-1434.

359. H. Fan, G. Wang, and L. Hu: 'Infrared, Raman and XPS spectroscopic studies of $\mathrm{Bi}_{2} \mathrm{O}_{3}-\mathrm{B}_{2} \mathrm{O}_{3}-$ $\mathrm{Ga}_{2} \mathrm{O}_{3}$ glasses', Solid State Sciences, 2009, 11(12), 2065-2070.

360. H. Fan, L. Hu, K. Yang, and Y. Fang: 'Structure and physical properties of $\mathrm{Bi}_{2} \mathrm{O}_{3}-\mathrm{B}_{2} \mathrm{O}_{3}-\mathrm{Ga}_{2} \mathrm{O}_{3}$ glasses', Journal of Non-Crystalline Solids, 2010, 356(35-36), 1814-1818.

361. Y. Zhang, Y. Yang, J. Zheng, W. Hua, and G. Chen: 'Effects of oxidizing additives on optical properties of $\mathrm{Bi}_{2} \mathrm{O}_{3}-\mathrm{B}_{2} \mathrm{O}_{3}-\mathrm{SiO}_{2}$ glasses', J. Am. Ceram. Soc., 2008, 91(10), 3410-3412.

362. G. Gao, L. Hu, H. Fan, G. Wang, K. Li, S. Feng, S. Fan, and H. Chen: 'Effect of $\mathrm{Bi}_{2} \mathrm{O}_{3}$ on physical, optical and structural properties of boron silicon bismuthate glasses', Optical Materials, 2009, 32(1), 159-163.

363. K. Gerth and C. Rüssel: 'Crystallization of $\mathrm{Bi}_{4} \mathrm{Ti}_{3} \mathrm{O}_{12}$ from glasses in the system $\mathrm{Bi}_{2} \mathrm{O}_{3} / \mathrm{TiO}_{2} / \mathrm{B}_{2} \mathrm{O}_{3}{ }^{\prime}$, Journal of Non-Crystalline Solids, 1997, 221(1), 10-17.

364. K. Gerth and C. Rüssel: 'Crystallization of $\mathrm{Bi}_{3} \mathrm{TiNbO}_{9}$ from glasses in the system $\mathrm{Bi}_{2} \mathrm{O}_{3} /$ $\mathrm{TiO}_{2} / \mathrm{Nb}_{2} \mathrm{O}_{5} / \mathrm{B}_{2} \mathrm{O}_{3} / \mathrm{SiO}_{2}{ }^{\prime}$, Journal of Non-Crystalline Solids, 1999, 243(1), 52-60.

365. Y. T. Fei, S. J. Fan, R. Y. Sun, and M. Ishii: 'Study on phase diagram of $\mathrm{Bi}_{2} \mathrm{O}_{3}-\mathrm{SiO}_{2}$ system for Bridgman growth of $\mathrm{Bi}_{4} \mathrm{Si}_{3} \mathrm{O}_{12}$ single crystal', Progress in Crystal Growth and Characterization of Materials, 2000, 40(1-4), 183-188.

366. J. Gackowska, M. Gazda, K. Trzebiatowski, and B. Kusz: 'Structure and electric conductivity of reduced lead-germanate, bismuth-germanate and bismuth-silicate glasses modified with potassium', Journal of Non-Crystalline Solids, 2008, 354(35-39), 4319-4322.

367. S. M. Abo-Naf, R. L. Elwan, and M. Marzouk: 'Structure-property correlations in the $\mathrm{SiO}_{2}-$ $\mathrm{PbO}-\mathrm{Bi}_{2} \mathrm{O}_{3}$ glasses', Journal of Materials Science: Materials in Electronics, 2012, 23(5), 1022-1030. 
368. L. Dimesso, G. Gnappi, A. Montenero, P. Fabeni, and G. P. Pazzi: 'The crystallization behaviour of bismuth germanate glasses', Journal of Materials Science, 1991, 26(15), 42154219.

369. K. Nassau and D. L. Chadwick: 'Glass-forming systems involving $\mathrm{GeO}_{2}$ with $\mathrm{Bi}_{2} \mathrm{O}_{3}, \mathrm{Tl}_{2} \mathrm{O}$, and PbO', J. Am. Ceram. Soc., 1982, 65(10), 486-491.

370. D. M. Shi, Y. G. Zhao, Q. Qian, D. D. Chen, and Q. Y. Zhang: 'Role of PbO substitution by $\mathrm{Bi}_{2} \mathrm{O}_{3}$ on $1.47 \mu \mathrm{m}$ luminescence properties of $\mathrm{Tm}^{3+} / \mathrm{Tb}^{3+}$-doped $\mathrm{Bi}_{2} \mathrm{O}_{3}-\mathrm{GeO}_{2}-\mathrm{Ga}_{2} \mathrm{O}_{3}$ glass', Journal of Alloys and Compounds, 2010, 499(1), 126-130.

371. Q. Y. Zhang, T. Li, Z. H. Jiang, X. H. Ji, and S. Buddhudu: '980 nm laser-diode-excited intense blue upconversion in $\mathrm{Tm}^{3+} / \mathrm{Yb}^{3+}$-codoped gallate-bismuth-lead glasses', Appl. Phys. Lett., 2005, 87(17), 171911.

372. A. Sen, D. Chakravorty, and J. Kumar: 'Infrared transmitting bismuth germanate glasses containing zinc oxide', Journal of Non-Crystalline Solids, 1986, 88(2-3), 253-261.

373. I. Ardelean, M. Peteanu, V. Simon, C. Bob, and S. Filip: 'EPR and magnetic susceptibility studies of $\mathrm{Cr}_{2} \mathrm{O}_{3}-\mathrm{Bi}_{2} \mathrm{O}_{3}-\mathrm{GeO}_{2}$ glasses', Journal of Materials Science, 1998, 33(2), 357-362.

374. P. Pascuta, L. Pop, S. Rada, M. Bosca, and E. Culea: 'The local structure of bismuth germanate glasses and glass ceramics doped with europium ions evidenced by FT-IR spectroscopy', Vibrational Spectroscopy, 2008, 48(2), 281-284.

375. A. Feltz and A. Morr: 'Redox reactions in condensed oxide systems. III. Glass formation and properties in the $\mathrm{Bi}_{2} \mathrm{O}_{3}-\mathrm{P}_{2} \mathrm{O}_{5}$ system', Journal of Non-Crystalline Solids, 1985, 74(2-3), 313324.

376. A. A. El Adawy: 'Effect of annealing temperature on the elastic properties of bismuth phosphate glasses', Journal of Materials Science Letters, 1996, 15(23), 2061-2064.

377. V. Y. Voevodskii, Y. F. Kargin, and V. M. Skorikov: 'System $\mathrm{Bi}_{2} \mathrm{O}_{3}-\mathrm{P}_{2} \mathrm{O}_{5}$ in composition range 50-85 mol\% $\mathrm{P}_{2} \mathrm{O}_{5}{ }^{\prime}$, Russian Journal of Inorganic Chemistry, 1997, 42(5), 715-717.

378. S. Rani, S. Sanghi, A. Agarwal, and N. Ahlawat: 'Influence of $\mathrm{Bi}_{2} \mathrm{O}_{3}$ on optical properties and structure of bismuth lithium phosphate glasses', Journal of Alloys and Compounds, 2009, 477, 504-509.

379. L. Pöppl and Z. Szaller: 'Reactions and phases within the $\mathrm{TeO}_{2}$-rich part of the $\mathrm{Bi}_{2} \mathrm{O}_{3}-\mathrm{TeO}_{2}$ system - the non-equilibrium phase diagram', Journal of Thermal Analysis and Calorimetry, 2003, 74(2), 375-386.

380. M. Udovic, M. Valant, B. Jančar, and D. Suvorov: 'Phase formation and crystal-structure determination in the $\mathrm{Bi}_{2} \mathrm{O}_{3}-\mathrm{TiO}_{2}-\mathrm{TeO}_{2}$ system prepared in an oxygen atmosphere', J. Am. Ceram. Soc., 2006, 89(11), 3462-3469.

381. J. Fu: 'Novel bismuthate glasses', Journal of Non-Crystalline Solids, 1996, 194(1-2), 207-209.

382. A. Pan and A. Ghosh: 'A new family of lead-bismuthate glass with a large transmitting window', Journal of Non-Crystalline Solids, 2000, 271(1-2), 157-161.

383. W. Wong-Ng, L. P. Cook, and F. Jiang: 'Subsolidus and melting study of the $\mathrm{Bi}_{2} \mathrm{O}_{3}-\mathrm{PbO}_{x}-\mathrm{CuO}$ system in air', Applied Superconductivity, 1996, 4(9), 385-397.

384. A. Radu, L. Baia, W. Kiefer, and S. Simon: 'The influence of manganese cations on the structure of lead high bismuthate glasses and glass ceramics', Vibrational Spectroscopy, 2005, 39(2), 127-130.

385. F. Miyaji and S. Sakka: 'Structure of $\mathrm{PbO}-\mathrm{Bi}_{2} \mathrm{O}_{3}-\mathrm{Ga}_{2} \mathrm{O}_{3}$ glasses', Journal of Non-Crystalline Solids, 1991, 134(1-2), 77-85.

386. A. A. Kharlamov, R. M. Almeida, and J. Heo: 'Vibrational spectra and structure of heavy metal oxide glasses', Journal of Non-Crystalline Solids, 1996, 202(3), 233-240. 
387. I. M. G. dos Santos, R. C. Martins Moreira, A. G. de Souza, R. Lebullenger, A. C. Hernandes, E. R. Leite, C. A. Paskocimas, and E. Longo: 'Ceramic crucibles: a new alternative for melting of $\mathrm{PbO}-\mathrm{BiO}_{1.5}-\mathrm{GaO}_{1.5}$ glasses', Journal of Non-Crystalline Solids, 2003, 319(3), 304-310.

388. T. Watanabe, T. Nanba, and Y. Miura: 'X-ray and neutron scattering study of the structure of lithium bismuth oxide glass', Journal of Non-Crystalline Solids, 2002, 297(1), 73-83.

389. K. Nassau, M. Grasso, and A. M. Glass: 'Quenched glasses in the systems of $\mathrm{Li}_{2} \mathrm{O}$ with $\mathrm{Al}_{2} \mathrm{O}_{3}$, $\mathrm{Ga}_{2} \mathrm{O}_{3}$ and $\mathrm{Bi}_{2} \mathrm{O}_{3}{ }^{\prime}$, Journal of Non-Crystalline Solids, 1979, 34(3), 425-436.

390. S. Hazra and A. Ghosh: 'Structure and properties of nonconventional glasses in the binary bismuth cuprate system', Physical Review B, 1995, 51(2), 851-856.

391. A. W. Gosh: 'Transport properties of iron-bismuthate glassy semiconductors', Journal of Applied Physics, 1989, 66(6), 2425.

392. A. Nitta, M. Koide, and K. Matusita: 'Glass formation and thermal properties of $\mathrm{Bi}_{2} \mathrm{O}_{3}-\mathrm{ZnO}$ $\mathrm{B}_{2} \mathrm{O}_{3}-\mathrm{R}_{2} \mathrm{O}$ quaternary systems', Physics and Chemistry of Glasses, 2001, 42(4-5), 275-278.

393. L. Baia, T. Ilescu, S. Simon, and W. Kiefer: 'Raman and IR spectroscopic studies of manganese doped $\mathrm{GeO}_{2}-\mathrm{Bi}_{2} \mathrm{O}_{3}$ glasses', Journal of Molecular Structure, 2001, 599(1-3), 9-13.

394. L. Baia, R. Stefan, W. Kiefer, J. Popp, and S. Simon: 'Structural investigations of copper doped $\mathrm{B}_{2} \mathrm{O}_{3}-\mathrm{Bi}_{2} \mathrm{O}_{3}$ glasses with high bismuth oxide content', Journal of Non-Crystalline Solids, 2002, 303(3), 379-386.

395. A. Nitta, T. Miura, T. Komatsu, and K. Matusita: 'Glass formation in the system $\mathrm{SiO}_{2}-\mathrm{PbO}$ containing transition-metal oxides', J. Am. Ceram. Soc., 1989, 72(1), 163-165.

396. K. Boonin, J. Kaewkhao, and P. Limsuwan: 'Optical investigation of $\mathrm{Bi}_{2} \mathrm{O}_{3}-\mathrm{B}_{2} \mathrm{O}_{3}$ glass system', Advanced Materials Research, 2010, 93-94, 336-339.

397. T. Takaishi, J. Jin, T. Uchino, and T. Yoko: 'Structural study of $\mathrm{PbO}-\mathrm{B}_{2} \mathrm{O}_{3}$ glasses by X-ray diffraction and ${ }^{11}$ B MAS NMR techniques', J. Am. Ceram. Soc., 2000, 83(10), 2543-2548.

398. A. Hayashi, M. Nakai, M. Tatsumisago, T. Minami, Y. Himei, Y. Miura, and M. Katada: 'Structural investigation of $\mathrm{SnO}-\mathrm{B}_{2} \mathrm{O}_{3}$ glasses by solid-state NMR and X-ray photoelectron spectroscopy', Journal of Non-Crystalline Solids, 2002, 306(3), 227-237.

399. J. A. Duffy and M. D. Ingram: 'An interpretation of glass chemistry in terms of the optical basicity concept', Journal of Non-Crystalline Solids, 1976, 21(3), 373-410.

400. V. Dimitrov and T. Komatsu: 'Classification of simple oxides: a polarizability approach', Journal of Solid State Chemistry, 2002, 163(1), 100-112.

401. J. Duffy: 'Relationship between cationic charge, coordination number, and polarizability in oxidic materials', Journal of Physical Chemistry B, 2004, 108(37), 14137-14141.

402. B. N. Meera and J. Ramakrishna: 'Raman spectral studies of borate glasses', Journal of NonCrystalline Solids, 1993, 159(1-2), 1-21.

403. A. Walsh: 'The origin of structural distortions in metal ceramics', $\mathrm{PhD}$ thesis, University of Dublin, Dublin (IE), 2006.

404. Y. D. Yiannopoulos, G. D. Chryssikos, and E. I. Kamitsos: 'Structure and properties of alkaline earth borate glasses', Physics and Chemistry of Glasses, 2001, 42(3), 164-172.

405. J. Zhong and P. J. Bray: 'Change in boron coordination in alkali borate glasses, and mixed alkali effects, as elucidated by NMR', Journal of Non-Crystalline Solids, 1989, 111(1), 67-76.

406. S. Bale, M. Purnima, C. Srinivasu, and S. Rahman: 'Vibrational spectra and structure of bismuth based quaternary glasses', Journal of Alloys and Compounds, 2008, 457(1-2), 545548 . 
407. T. Yoko, K. Tadanaga, F. Miyaji, and S. Sakka: 'A ${ }^{207} \mathrm{~Pb}$ MAS-NMR study of Pb-containing glasses', Journal of Non-Crystalline Solids, 1992, 150(1-3), 192-196.

408. A. Witkowska, J. Rybicki, and A. di Cicco: 'Structure of partially reduced bismuth-silicate glasses: EXAFS and MD study', Journal of Alloys and Compounds, 2005, 401, 135-144.

409. A. Witkowska, B. Sikora, K. Trzebiatowski, and J. Rybicki: 'Germanate anomaly in heavy metal oxide glasses: an EXAFS analysis', Journal of Non-Crystalline Solids, 2006, 352(4041), 4356-4361.

410. N. Umesaki, T. M. Brunier, A. C. Wright, A. C. Hannon, and R. N. Sinclair: 'Neutron scattering from $\mathrm{PbO}-\mathrm{GeO}_{2}$ glasses', Journal of Non-Crystalline Solids, 1995, 213-214, 490492.

411. M. Imaoka, H. Hasegawa, and I. Yasui: 'X-ray diffraction analysis on the structure of the glasses in the system PbO-SiO${ }_{2}^{\prime}$, Journal of Non-Crystalline Solids, 1986, 85(3), 393-412.

412. F. Fayon, C. Landron, K. Sakurai, C. Bessada, and D. Massiot: 'Pb ${ }^{2+}$ environment in lead silicate glasses probed by $\mathrm{Pb}-\mathrm{L}_{\mathrm{III}}$ edge XAFS and ${ }^{207} \mathrm{~Pb}$ NMR', Journal of Non-Crystalline Solids, 1999, 243(1), 39-44.

413. P. Ghigna, P. Mustarelli, C. Tomasi, E. Quartarone, M. Scavini, A. Speghini, and M. Bettinelli: 'A combined nuclear magnetic resonance and X-ray absorption fine structure study on the local structures of $\mathrm{Ge}$ and $\mathrm{Pb}$ in $\mathrm{PbO}-\mathrm{GeO}_{2}$ glasses and their relationships with thermal properties and devitrification products', Journal of Physical Chemistry B, 2002, 106(38), 9802-9809.

414. P. W. Wang and L. P. Zhang: 'Structural role of lead in lead silicate glasses derived from XPS spectra', Journal of Non-Crystalline Solids, 1996, 194(1-2), 129-134.

415. J. F. Bent, A. C. Hannon, D. Holland, and M. M. A. Karim: 'The structure of tin silicate glasses', Journal of Non-Crystalline Solids, 1998, 232-233, 300-308.

416. W. H. Zachariesen: 'The atomic arrangement in glass', J. Am. Ceram. Soc., 1932, 54(10), 3841-3851.

417. A. J. G. Ellison and S. Sen: 'Role of $\mathrm{Sb}^{3+}$ as a network-forming cation in oxide glasses', Physical Review B, 2003, 67(5), 052203.

418. D. Holland, A. C. Hannon, M. E. Smith, C. E. Johnson, M. F. Thomas, and A. M. Beesley: 'The role of $\mathrm{Sb}^{5+}$ in the structure of $\mathrm{Sb}_{2} \mathrm{O}_{3}-\mathrm{B}_{2} \mathrm{O}_{3}$ binary glasses - an NMR and Mössbauer spectroscopy study', Solid State Nuclear Magnetic Resonance, 2004, 26(3-4), 172-179.

419. H. Seki, K. Satoh, and H. Satoh: 'A new adhesion process of glass to metal using the redox reaction', Journal of Materials Science, 1996, 31(18), 4891-4898.

420. G. Humpston and D. M. Jacobson: 'The joining environment', in 'Principles of Soldering', 2004, ASM International (USA).

421. Z. Yuan, J. Fan, J. Li, J. Ke, and K. Mukai: 'Surface tension of molten bismuth at different oxygen partial pressure with the sessile drop method', Scandinavian Journal of Metallurgy, 2004, 33(6), 338-346.

422. J. Zhang and N. Li: 'Review of studies on fundamental issues in LBE corrosion', AFCI Technical Document LA-UR-04-0869, Los Alamos National Laboratory, USA, 2004.

423. J. Pierce, D. Kuty, and J. Larry: 'The chemistry and stability of ruthenium-based resistors', Proceedings, Third European Hybrid Microelectronics Conference, Avignon (F), 1981, 283301.

424. O. Claussen and C. Rüssel: 'Thermodynamics of various polyvalent main group elements in a borosilicate glass melt', Journal of Non-Crystalline Solids, 1997, 209(3), 292-298. 
425. B. Kusz and K. Trzebiatowski: 'Bismuth germanate and bismuth silicate glasses in cryogenic detectors', Journal of Non-Crystalline Solids, 2003, 319(3), 257-262.

426. S. Khonthon, S. Morimoto, Y. Arai, and Y. Ohishi: 'Redox equilibrium and NIR luminescence of $\mathrm{Bi}_{2} \mathrm{O}_{3}$-containing glasses', Optical Materials, 2009, 31, 1262-1268.

427. S. P. Singh and B. Karmakar: 'Oxidative control of surface plasmon resonance of bismuth nanometal in bismuth glass nanocomposites', Materials Chemistry and Physics, 2010, 119(3), $355-358$

428. M. Peng, B. Wu, N. Da, W. Chen, and D. Chen: 'Bismuth-activated luminescent materials for broadband optical amplifier in WDM system', Journal of Non-Crystalline Solids, 2008, 354(12-13), 1221-1225.

429. J. Ren, J. Qiu, D. Chen, X. Hu, X. Jiang, and C. Zhu: 'Luminescence properties of bismuthdoped lime silicate glasses', Journal of Alloys and Compounds, 2008, 463(1-2), L5-L8.

430. G. Chi, D. Zhou, Z. Song, and J. Qiu: 'Effect of optical basicity on broadband infrared fluorescence in bismuth-doped alkali metal germanate glasses', Optical Materials, 2009, 31, 945-948.

431. J. Y. Song, T. J. Park, and S. Y. Choi: 'Preparation and characterization of $\mathrm{CuO}$ doped $\mathrm{Bi}_{2} \mathrm{O}_{3}-$ $\mathrm{B}_{2} \mathrm{O}_{3}-\mathrm{BaO}-\mathrm{ZnO}$ glass system for transparent dielectric layer', Journal of Non-Crystalline Solids, 2006, 352(50-51), 5403-5407.

432. G. J. Roberts: 'Bismuth-containing lead-free glass enamels and glazes of low silica content', Patent US5326591, USA, 1994.

433. S. Hwang, Y. Kim, M. Park, and H. Kim: 'Devitrification of bismuth oxide seal frit for backlight unit lamp in LCD', Molecular Crystals and Liquid Crystals, 2007, 470, 137-144.

434. M. Coleman and A. Winster: 'Silver migration in thick film conductors and chip attachment resins', Microelectronics Journal, 1981, 12(4), 23-29.

435. S. Lee, S. Hwang, M. Cha, and H. Kim: 'Role of copper ion in preventing silver nanoparticles forming in $\mathrm{Bi}_{2} \mathrm{O}_{3}-\mathrm{B}_{2} \mathrm{O}_{3}-\mathrm{ZnO}$ glass', Journal of Physics and Chemistry of Solids, 2008, 69(56), 1498-1500.

436. S. Sridharan, R. Blonski, I. H. Joyce, G. C. Korn, and J. Anquetil: 'Durable glass enamel composition', Patent, 2003-11, 2003.

437. G. E. Sakoske: 'Partially crystallizing enamel containing crystalline zinc borate seed material', Patent US5677251, USA, 1997.

438. G. E. Sakoske and J. W. Ryan: 'Partially crystallizing ceramic enamel composition containing bismuth silicate, and use thereof', Patent USA5714420, USA, 1998.

439. G. E. Sakoske: 'Partially crystallizing lead-free enamel composition for automobile glass', Patent US6022624, USA, 2000.

440. G. E. Sakoske and G. Tunker: 'High durability low temperature lead-free glass and enamel compositions with low boron content', Patent US2002/0004443, USA, 2002.

441. M. H. Krohn, J. R. Hellmann, D. L. Shelleman, C. G. Pantano, and G. E. Sakoske: 'Effect of enameling on the strength and dynamic fatigue of soda-lime-silica float glass', Journal of the American Society, 2002, 85(10), 2507-2514.

442. T. Maeder, C. Jacq, and P. Ryser: 'Long-term mechanical reliability of ceramic thick-film circuits and mechanical sensors under static load', Sens. Actuat. A, 2012, 186, 210-218.

443. S. Ram and K. A. Narayan: 'Controlled crystallization of $\mathrm{PbO}-\mathrm{Cr}_{2} \mathrm{O}_{3}-\mathrm{B}_{2} \mathrm{O}_{3}$ glasses and a catalytic effect of $\mathrm{Al}_{2} \mathrm{O}_{3}$ for the growth of $\mathrm{Pb}_{2} \mathrm{CrO}_{5}$ microcrystals', Industrial \& Engineering Chemistry Research, 1987, 26(6), 1051-1055. 
444. Y. H. Liu, J. B. Li, J. K. Liang, J. Luo, L. N. Ji, J. Y. Zhang, and G. H. Rao: 'Phase diagram of the $\mathrm{Bi}_{2} \mathrm{O}_{3}-\mathrm{Cr}_{2} \mathrm{O}_{3}$ system', Materials Chemistry and Physics, 2008, 112(1), 239-243.

445. C. Jacq, T. Maeder, S. Vionnet, and P. Ryser: 'Low-temperature thick-film dielectrics and resistors for metal substrates', J. Eur. Ceram. Soc., 2005, 25(12), 2121-2124.

446. M. Bilinski, E. Eisermann, W. Jones, K, W. Smetana, M. Unger, and J. Whitmarsh: 'Thick film pastes for the manufacture of low cost, insulated aluminium substrates for use as integrated heat sinks for high intensity LEDs', Proceedings, XXXII International Conference of IMAPS Poland Chapter, Puttusk, Poland, 2008, I12.

447. S. S. Cole: 'Sintering of Ag-Pd in the presence of a reactive glass', J. Am. Ceram. Soc., 1972, 55(6), 296-299.

448. J. R. Larry, R. M. Rosenberg, and R. O. Uhler: 'Thick-film technology: an introduction to the materials', IEEE Transactions on Components, Hybrids and Manufacturing Technology, 1980, 3(2), 211-225.

449. B. E. Taylor, J. J. Felten, and J. R. Larry: 'Progress in and technology of low-cost silver containing thick-film conductors', IEEE Transactions on Components, Hybrids and Manufacturing Technology, 1980, 3(4), 504-517.

450. S. Wang and W. Huebner: 'Interaction of $\mathrm{Ag} / \mathrm{Pd}$ metallization with lead and bismuth oxidebased fluxes in multilayer ceramic capacitors', J. Am. Ceram. Soc., 1992, 75(9), 2339-2352.

451. S. F. Wang and W. Huebner: 'Interaction of silver / palladium electrodes with lead- and bismuth-based electroceramics', J. Am. Ceram. Soc., 1993, 76(2), 474-480.

452. T. Inoue: 'Conductive paste for thick-film circuit', Patent JP54060497, Japan, 1979.

453. T. V. Nordstrom and F. G. Yost: 'Sintering behavior of a reactively bonded thick film gold ink', Journal of Electronic Materials, 1978, 7(1), 109-122.

454. Y. S. Chung and H. G. Kim: 'Effect of oxide glass on the sintering behavior and electrical properties in Ag thick films', IEEE Transactions on Components, Hybrids and Manufacturing Technology, 1988, 11(2), 195-199.

455. S. B. Rane, V. Puri, and D. Amalnerkar: 'A study on sintering and microstructure development of fritless silver thick film conductor', Journal of Materials Science: Materials in Electronics, 2000, 11(9), 667-674.

456. S. B. Rane, T. Seth, G. J. Phatak, D. Amalnerkar, and M. Ghatpande: 'Effect of inorganic binders on the properties of silver thick films', Journal of Materials Science: Materials in Electronics, 2004, 15(2), 103-106.

457. K. Takaoka: 'Gold thick film pastes', in 'Gold - Science and Applications', (eds. C. Corti, et al.), 279-286; 2010, CRC Press (USA).

458. M. Hrovat and D. Kolar: 'Investigation in the $\mathrm{Al}_{2} \mathrm{O}_{3}-\mathrm{Bi}_{2} \mathrm{O}_{3}-\mathrm{CuO}$ system', Journal of Materials Science Letters, 1984, 3(8), 659-662.

459. S. Immovilli, B. Morten, M. Prudenziati, A. Gualtieri, and M. Bersani: 'Interactions between bismuth oxide and ceramic substrates for thick film technology', Journal of Materials Research, 1998, 13(7), 1865-1874.

460. M. Hrovat, S. Bernik, and D. Kolar: 'Phase equilibria in the $\mathrm{RuO}_{2}-\mathrm{Bi}_{2} \mathrm{O}_{3}-\mathrm{PdO}$ system', Journal of Materials Science Letters, 1988, 7(6), 637-638.

461. G. Iles and M. Casale: 'Ruthenium oxide glaze resistors - new screen printing preparations for thick film circuitry', Platinum Metals Review, 1967, 11(4), 126-129.

462. M. Ansell: 'Conduction processes in thick film resistors. Part I', Electrocomponent Science and Technology, 1976, 3(3), 131-140. 
463. Y. M. Chiang, L. A. Silverman, R. H. French, and R. M. Cannon: 'Thin glass film between ultrafine conductor particles in thick-film resistors', J. Am. Ceram. Soc., 1994, 77(5), 1143 1152 .

464. K. Adachi and H. Kuno: 'Decomposition of ruthenium oxides in lead borosilicate glass', $J$. Am. Ceram. Soc., 1997, 80(5), 1055-1064.

465. S. Vionnet, T. Maeder, and P. Ryser: 'Firing, quenching and annealing studies on thick-film resistors', J. Eur. Ceram. Soc., 2004, 24(6), 1889-1892.

466. T. Inokuma and Y. Taketa: 'Control of electrical properties of $\mathrm{RuO}_{2}$ thick film resistors', Active and Passive Electronic Components, 1987, 12(3), 155-166.

467. R. Weissmann and C. Wang: 'Glasses for high-resistivity thick-film resistors', Advanced Engineering Materials, 2000, 2(6), 359-362.

468. V. Shante and S. Kirkpatrick: 'An introduction to percolation theory', Advances in Physics, 1971, 20(85), 325-357.

469. G. E. Pike and C. H. Seager: 'Electrical properties and conduction mechanisms of Ru-based thick-film (cermet) resistors', Journal of Applied Physics, 1977, 48(12), 5152-5169.

470. P. Ewen and J. Robertson: 'A percolation model of conduction in segregated systems of metallic and insulating materials: application to thick film resistors', Journal of Physics D: Applied Physics, 1981, 14, 2253-2268.

471. M. Prudenziati: 'Electrical transport in thick film (cermet) resistors', Electrocomponent Science and Technology, 1983, 10(4), 285-293.

472. A. Dziedzic: 'Bibliography on electrical conduction in thick film resistors', Microelectron. Reliab., 1991, 31(2-3), 549-558.

473. C. Grimaldi, T. Maeder, P. Ryser, and S. Strässler: 'Segregated tunneling-percolation model for transport nonuniversality', Physical Review B, 2003, 68(2), 024207.

474. G. Ambrosetti, N. Johner, C. Grimaldi, T. Maeder, P. Ryser, and A. Danani: 'Electron tunneling in conductor-insulator composites with spherical fillers', Journal of Applied Physics, 2009, 106, 016103.

475. K. Murhty and A. Kumar: 'Failure mechanisms in bismuth ruthenate resistor systems', Journal of Materials Science: Materials in Electronics, 1990, 1(2), 61-71.

476. K. Adachi and H. Kuno: 'Effect of glass composition on the electrical properties of thick-film resistors', J. Am. Ceram. Soc., 2000, 83(10), 2441-2448.

477. A. Dziedzic: 'Thick film resistors with $\mathrm{IrO}_{2}$ and $\mathrm{CaIr}_{x} \mathrm{Ti}_{1-x} \mathrm{O}_{3}$ - examples of chemically reactive and unreactive systems', Microelectronics Journal, 1988, 19(6), 24-42.

478. S. Tankiewicz, B. Morten, M. Prudenziati, and L. J. Golonka: ' $\mathrm{IrO}_{2}$-based thick-film resistors', Journal of Applied Physics, 2002, 91(7), 4261-4266.

479. W. D. Ryden, A. W. Lawson, and C. C. Sartain: 'Temperature dependance of the resistivity of $\mathrm{RuO}_{2}$ and $\mathrm{IrO}_{2}{ }^{\prime}$, Physics Letters, 1968, 26A(5), 209-210.

480. J. M. Longo, P. M. Raccah, and J. B. Goodenough: $\mathrm{Pb}_{2} \mathrm{M}_{2} \mathrm{O}_{7-x}(\mathrm{M}=\mathrm{Ru}, \mathrm{Ir}, \mathrm{Re})$ - preparation and properties of oxygen deficient pyrochlores', Materials Research Bulletin, 1969, 4(3), 191202.

481. W. D. Ryden, A. W. Lawson, and C. C. Sartain: 'Electrical transport properties of $\mathrm{IrO}_{2}$ and $\mathrm{RuO}_{2}{ }^{\prime}$, Physical Review B, 1970, 1(4), 1494-1500.

482. R. J. Bouchard and J. L. Gillson: 'A new family of bismuth - precious metal pyrochlores', Materials Reseach Bulletin, 1971, 6(8), 669-680. 
483. H. S. Horowitz, J. M. Longo, and J. T. Lewandowski: 'New oxide pyrochlores: $A_{2}\left[B_{2-x} A_{x}\right] O_{7-y}$ $(\mathrm{A}=\mathrm{Pb}, \mathrm{Bi} ; \mathrm{B}=\mathrm{Ru}, \mathrm{Ir})^{\prime}$, Materials Research Bulletin, 1981, 16(5), 489-496.

484. R. A. Beyerlein, H. S. Horowitz, J. M. Longo, M. E. Leonowicz, J. D. Jorgensen, and F. J. Rotella: 'Neutron diffraction investigation of ordered oxygen vacancies in the defect pyrochlores, $\mathrm{Pb}_{2} \mathrm{Ru}_{2} \mathrm{O}_{6.5}$ and $\mathrm{PbTlNb}_{2} \mathrm{O}_{6.5}$ ', Journal of Solid State Chemistry, 1984, 51(2), $253-$ 265.

485. M. Schuler and S. Kemmler-Sack: 'Systeme $\mathrm{Bi}_{2-x} \mathrm{~B}_{x} \mathrm{Ru}_{2} \mathrm{O}_{7-x}(\mathrm{~B}=\mathrm{Mn}, \mathrm{Co}, \mathrm{Ni}, \mathrm{Cu}, \mathrm{Zn}, \mathrm{Cd}, \mathrm{Mg}$, $\mathrm{Ca}, \mathrm{Sr})^{\prime}$, Journal of the Less-Common Metals, 1984, 102(1), 105-112.

486. A. Dziedzic and L. Golonka: 'Electrical properties of conductive materials used in thick-film resistors', Journal of Materials Science, 1988, 23(9), 3151-3155.

487. K. M. Y. Yi, K. W. Lee, K. W. Chung, W. S. Um, H. S. Lee, J. K. Song, and I. S. Lee: 'Conductive powder preparation and electrical properties of $\mathrm{RuO}_{2}$ thick film resistors', Journal of Materials Science: Materials in Electronics, 1997, 8(4), 247-251.

488. K. Gurunathan, N. P. Vyawahare, G. J. Phatak, and D. P. Amalnerkar: 'Solution route synthesis and characterization of nanocrystalline $\mathrm{Bi}_{2} \mathrm{Ru}_{2} \mathrm{O}_{7}$ for usage in resistor paste application', Journal of Materials Science: Materials in Electronics, 2005, 16(3), 159-168.

489. J. Pagnaer, D. Nelis, D. Mondelaers, G. Vanhoyland, J. D’Haen, B. Van, MK., H. Van den Rul, J. Mullens, and L. Van Poucke: 'Synthesis of $\mathrm{RuO}_{2}$ and $\mathrm{SrRuO}_{3}$ powders by means of aqueous solution gel chemistry', J. Eur. Ceram. Soc., 2004, 24(6), 919-923.

490. J. B. Goodenough: 'Metallic oxides', Progress in Solid State Chemistry, 1971, 5(C), 145-399.

491. B. Morten, A. Masoero, M. Prudenziati, and T. Manfredini: 'Evolution of ruthenate-based thick film cermet resistors', Journal of Physics D: Applied Physics, 1994, 27(10), 2227-2235.

492. M. V. H. Rao, V. D. Giramkar, G. J. Phatak, D. P. Amalnerkar, K. S. Sastri, and V. N. Krishnamurthy: 'Microstructure and electrical properties of 'pre-sintered bismuth ruthenateglass composite' based thick film paste for resistor application', International Journal of Electronics, 2005, 92(8), 451-456.

493. A. Prabhu, G. L. Fuller, and R. W. Vest: 'Solubility of $\mathrm{RuO}_{2}$ in a $\mathrm{Pb}$ borosilicate glass', J. Am . Ceram. Soc., 1974, 57(9), 408-409.

494. P. Palanisamy, D. H. R. Sarma, and R. W. Vest: 'Solubility of ruthenium dioxide in lead borosilicate glasses', J. Am. Ceram. Soc., 1989, 72(9), 1755-1756.

495. K. Adachi, S. Iida, and K. Hayashi: 'Ruthenium clusters in lead-borosilicate glass in thick film resistors', Journal of Materials Research, 1994, 9(7), 1866-1878.

496. S. Vionnet-Menot, T. Maeder, C. Grimaldi, C. Jacq, and P. Ryser: 'Properties and stability of thick-film resistors with low processing temperatures - effect of composition and processing parameters', 15th European Microelectronics and Packaging Conference (EMPC), Brugge (BE), 2005-06, 2005, IMAPS, P2.05, 571-576.

497. B. Řehák, M. Frumar, and L. Koudelka: 'Effect of atmosphere on the electrical conductivity of $\mathrm{RuO}_{2}$ and ruthenate layers', Journal of Materials Science Letters, 1984, 3, 1011-1014.

498. T. Nakano and T. Yamaguchi: 'Effect of $\mathrm{O}_{2}$ concentration in firing atmosphere on resistance of $\mathrm{RuO}_{2}$-glass thick-film resistors', J. Am. Ceram. Soc., 1995, 78(6), 1703-1704.

499. T. Ryll, A. Brunner, S. Ellenbroek, A. Bieberle-Hütter, J. L. M. Rupp, and L. J. Gauckler: 'Electrical conductivity and crystallization of amorphous bismuth ruthenate thin films deposited by spray pyrolysis', Physical Chemistry Chemical Physics, 2010, 12(42), 1393313942.

500. M. Prudenziati, B. Morten, L. Moro, L. Olumekor, and A. Tombesi: 'Interactions between thick-film resistors and terminations: the role of bismuth', Journal of Physics D: Applied Physics, 1986, 19(2), 275-282. 
501. M. Hrovat, S. Bernik, J. Holc, and D. Kolar: 'Subsolidus phase equilibria in the $\mathrm{RuO}_{2}-\mathrm{Bi}_{2} \mathrm{O}_{3}$ $\mathrm{ZnO}$ and $\mathrm{RuO}_{2}-\mathrm{Al}_{2} \mathrm{O}_{3}-\mathrm{ZnO}$ systems', Journal of Materials Science Letters, 1996, 15(4), 336-338.

502. M. Hrovat, J. Holc, and D. Kolar: 'Phase equilibria in $\mathrm{RuO}_{2}-\mathrm{TiO}_{2}-\mathrm{Al}_{2} \mathrm{O}_{3}$ and $\mathrm{RuO}_{2}-\mathrm{TiO}_{2}-$ $\mathrm{Bi}_{2} \mathrm{O}_{3}$ systems', Journal of Materials Science Letters, 1993, 12(23), 1858-1860.

503. S. Bernik, M. Hrovat, and D. Kolar: 'Phase equilibria in the $\mathrm{RuO}_{2}-\mathrm{Bi}_{2} \mathrm{O}_{3}-\mathrm{CuO}$ system', Journal of Materials Science Letters, 1991, 10(1), 69-70.

504. M. Hrovat, Z. Samardžia, J. Holc, and D. Kolar: 'Phase equilibria in the $\mathrm{RuO}_{2}-\mathrm{Bi}_{2} \mathrm{O}_{3}-\mathrm{NiO}$ and $\mathrm{RuO}_{2}-\mathrm{Al}_{2} \mathrm{O}_{3}-\mathrm{NiO}$ systems', Journal of Materials Science Letters, 1995, 14(7), 506-507.

505. M. Hrovat, S. Bernik, and D. Kolar: 'Phase equilibria in the $\mathrm{RuO}_{2}-\mathrm{PbO}-\mathrm{Al}_{2} \mathrm{O}_{3}$ and $\mathrm{RuO}_{2}$ $\mathrm{PbO}$ - CuO systems', Journal of Materials Science Letters, 1993, 12(23), 1848-1850.

506. T. Chen, T. Djeu, and T. Li: 'Excess noise in nitrogen fired thick film resistors', The International Journal for Hybrid Microelectronics, 1982, 5(2), 92-97.

507. E. Browne and B. Walton: 'An air firing base-metal resistor and conductor system for low-cost thick-film circuit manufacture', Electrocomponent Science \& Technology, 1981, 8(1-2), 61-65.

508. V. G. Grebenkina and M. D. Smolin: 'Thick-film cobalt molybdate-base resistors for highvoltage voltage dividers', Powder Metallurgy and Metal Ceramics, 1994, 33(1-2), 95-96.

509. L. Akulova, M. Vlasova, I. Voropaeva, and O. Horpyakov: 'Behaviour of molybdenum diboride in resistive thick film', Journal of Materials Science, 1992, 27(12), 3293-3296.

510. S. Achmatowicz, M. Jakubowska, E. Zwierkowska, and M. Primovitch: 'Low cost thick film resistive compositions without the use of noble metals', Microelectronics International, 1995, 12(2), 23-25.

511. S. Achmatowicz, M. Jakubowska, E. Zwierkowska, K. Pitt, and M. Primovitch: 'A robust low cost thick film system for the consumer market', Journal of Materials Science: Materials in Electronics, 1999, 10(7), 487-490.

512. M. Jakubowska, J. Kalenik, A. Miecznik, and E. Zwierkowska: 'Electrical and stability properties of molybdenum oxide based thick film resistors', Proceedings, XXVII International Conference of IMAPS Poland Chapter, Podlesice, Poland, 2003, 27, 174-176.

513. L. He, J. R. Anderson, H. F. Franzen, and D. C. Johnson: 'Electrocatalysis of anodic oxygentransfer reactions: $\mathrm{Bi}_{3} \mathrm{Ru}_{3} \mathrm{O}_{11}$ electrodes in acidic media', Chemistry of Materials, 1997, 9(3), 715-722.

514. R. Strobel, H. J. Metz, and S. Pratsinis: 'Brilliant yellow, transparent pure, and $\mathrm{SiO}_{2}$-coated $\mathrm{BiVO}_{4}$ nanoparticles made in flames', Chemistry of Materials, 2008, 20(20), 6346-6351.

515. M. Mehring: 'From molecules to bismuth oxide-based materials: Potential homo- and heterometallic precursors and model compounds', Coordination Chemistry Reviews, 2007, 251(7-8), 974-1006.

516. R. Venkatasubramanian, E. Siivola, T. Colpitts, and B. O'Quinn: 'Thin-film thermoelectric devices with high room-temperature figures of merit', Nature, 2001, 413, 597-602.

517. S. O. Leontsev and R. E. Eitel: 'Progress in engineering high strain lead-free piezoelectric ceramics', Science and Technology of Advanced Materials, 2010, 11(4), 044302.

518. W. Jo, E. Erdem, R. A. Eichel, J. Glaum, T. Granzow, D. Damjanovic, and J. Rödel: 'Effect of $\mathrm{Nb}$-donor and Fe-acceptor dopants in $\left(\mathrm{Bi}_{1 / 2} \mathrm{Na}_{1 / 2}\right) \mathrm{TiO}_{3}-\mathrm{BaTiO}_{3}-\left(\mathrm{K}_{0.5} \mathrm{Na}_{0.5}\right) \mathrm{NbO}_{3}$ lead-free piezoceramics', Journal of Applied Physics, 2010, 108(1), 014110.

519. T. Takahashi and H. Iwahara: 'Oxide ion conductors based on bismuth sesquioxide', Materials Research Bulletin, 1978, 13(2), 1447-1453. 
520. A. M. Azad, S. Larose, and S. A. Akbar: 'Bismuth oxide-based solid electrolytes for fuel cells', Journal of Materials Science, 1994, 29(16), 4135-4151.

521. P. Shuk, H. D. Wiemhöfer, U. Guth, W. Göpel, and M. Greenblatt: 'Oxide ion conducting solid electrolytes based on $\mathrm{Bi}_{2} \mathrm{O}_{3}{ }^{\prime}$, Solid State Ionics, 1996, 89(3-4), 179-196.

522. N. M. Sammes, G. A. Tompsett, H. Näfe, and F. Aldinger: 'Bismuth based oxide electrolytes structure and ionic conductivity', J. Eur. Ceram. Soc., 1999, 19(10), 1801-1826.

523. K. Brinkman, T. Iijima, and $\mathrm{H}$. Takamura: 'The oxygen permeation characteristics of $\mathrm{Bi}_{1-}$ ${ }_{x} \mathrm{Sr}_{x} \mathrm{FeO}_{3}$ mixed ionic and electronic conducting ceramics', Solid State Ionics, 2010, 181(1-2), 53-58.

524. H. Maeda, Y. Tanaka, M. Fukutomi, T. Asano, K. Togano, H. Kumakura, M. Uehara, S. Ikeda, K. Ogawa, S. Horiuchi, and Y. Matsui: 'New high-Tc superconductors without rare earth element', Physica C, 1988, 153-155(1), 602-607.

525. P. Majewski: 'BiSrCaCuO high- $\mathrm{T}_{\mathrm{c}}$ superconductors', Advanced Materials, 1994, 6(6), 460469.

526. D. G. Hinks: 'The nature of superconductivity in $\mathrm{Ba}_{1-\mathrm{x}} \mathrm{K}_{\mathrm{x}} \mathrm{BiO}_{3}$ ', MRS Bulletin, 1990, 15, 55-59.

527. M. Kobayashi, M. Ishii, K. Harada, and I. Yamaga: 'Bismuth silicate $\mathrm{Bi}_{4} \mathrm{Si}_{3} \mathrm{O}_{12}$, a faster scintillator than bismuth germanate $\mathrm{Bi}_{4} \mathrm{Ge}_{3} \mathrm{O}_{12}$ ', Nuclear Instruments and Methods in Physics Research, 1996, A372, 45-50.

528. V. Vaithianathan, A. Claude, P. Santhanaraghavan, and P. Ramasamy: 'On the energy and time resolution measurements of bismuth germanium silicon oxide (BGSO) crystal grown by Czochralski technique', Journal of Crystal Growth, 2005, 273, 481-488.

529. C. K. Kwok, D. P. Vijay, D. B. Sheshu, N. R. Parikh, and E. A. Hill: 'Conducting oxide electrodes for ferroelectric films', Integrated Ferroelectrics, 1993, 3(2), 121-130.

530. B. H. Park, B. S. Kang, S. D. Bu, T. W. Noh, J. Lee, and W. Jo: 'Lanthanum-substituted bismuth titanate for use in non-volatile memories', Nature, 1999, 401, 682-684.

531. K. Amanuma, T. Hase, and Y. Miyasaka: 'Preparation and ferroelectric properties of $\mathrm{SrBi}_{2} \mathrm{Ta}_{2} \mathrm{O}_{9}$ thin films', Appl. Phys. Lett., 1995, 66(2), 221-223.

532. S. T. Zhang, B. Sun, B. Yang, Y. F. Chen, Z. G. Liu, and N. B. Ming: ' $\operatorname{SrBi}_{4} \operatorname{Ti}_{4} \mathrm{O}_{15}$ thin films of Ti containing bismuth-layered-ferroelectrics prepared by pulsed laser deposition', Materials Letters, 2001, 47(6), 334-338.

533. Anon: 'Minerals yearbook', U.S. Geological Survey (USGS), USA, 2010.

534. X. Yang, H. Liu, H. Zhao, X. Zhang, X. Liang, and W. Xiang: 'Fabrication and third-order optical nonlinearities of $\mathrm{Na}_{2} \mathrm{O}-\mathrm{B}_{2} \mathrm{O}_{3}-\mathrm{SiO}_{2}$ glasses containing metallic $\mathrm{Bi}, \mathrm{Bi}_{2} \mathrm{O}_{3}$ and $\mathrm{Bi}_{2} \mathrm{~S}_{3}$ crystals', Materials Chemistry and Physics, 2011, 192(1-2), 121-129. 


\section{Description of supplementary material}

The supplements consist of the following sections:

- Supplement 10 gives a historical perspective of lead and bismuth in oxide glasses, including the development of awareness of the toxicity of lead and of the need to strongly limit exposure to this element.

- Supplement 11 presents and discusses the comparative toxicity of the elements found in common and special oxide glasses. This provides a rough guide to potential hazards and adequate formulation, bearing in mind that chemical (leaching) resistance must also be considered.

- Supplement 12 discusses the valence of bismuth in oxide glasses, usually taken to be $\mathrm{Bi}^{3+}$, in the light of the occasionally reported presence of $\mathrm{Bi}^{5+}$. A strong case is made against significant presence of $\mathrm{Bi}^{5+}$ species in most glasses processed by melting and quenching, with the possible exception of some very alkaline formulations melted at moderate temperatures. Hence, the darkening observed in glasses melted at high temperatures is rather attributed to the formation of reduced species.

- Supplement 13 compiles and discusses the bonding and oxygen coordination of $\mathrm{Bi}^{3+}$, compared to $\mathrm{Pb}^{2+}$ and $\mathrm{Sn}^{2+}$, in crystalline oxides, including pure or doped polymorphs of $\mathrm{Bi}_{2} \mathrm{O}_{3}$, compounds (borates, silicates, germanates, phosphates) lying close to or within the glass-forming range, and the pyrochlore-structure conducting phases. This provides useful supporting information for the discussion on glass structure, in section 3.3.

- Supplement 14 describes the assumptions used in this work to determine a rough estimate - when not given by the authors - of the cooling rate of the glass after melting. The cooling rate influences the vitrification ability (section 3.2), but may also somewhat affect the properties, which will be further influenced by annealing.

- The additional bibliography for the supplements is given in supplemental section 15 . 


\section{Lead and bismuth in glass - a historical perspective}

This section gives a short historical perspective on the use of lead and bismuth in glasses and awareness of the toxicity of lead - taken from several reference works. ${ }^{5,89,535-546} \mathrm{~A}$ summarised timeline may be found in Table 24, and a few representative compositions are given in Table 25.

\subsection{Lead and bismuth in glasses}

Glassy materials were first obtained sometime before $3000 \mathrm{BC}$ by in-situ glazing reaction between a siliceous body (bulk stone or ground quartz - faience) and an alkali-lime powder. Early colours were limited copper blue and manganese black, together with the ubiquitous iron brown. ${ }^{5,542,543}$ With the introduction of true bulk glass around $1500 \mathrm{BC}^{542,543}$ came a progressive extension of the available colour range, and, for the first time, introduction of low amounts of lead, albeit only to colour the glass yellow by forming lead antimonate $\left(\mathrm{Pb}_{2} \mathrm{Sb}_{2} \mathrm{O}_{7}\right)$. As considerable excess $\mathrm{Pb}$ was added over $\mathrm{Sb}$, some of the glasses had a low (1-2 cation $\mathrm{mol} \%$ ) content of $\mathrm{PbO},{ }^{543}$ which however was of little practical significance.

Introduction of leaded glazes came only shortly before the current era $\left(4^{\text {th }}-1^{\text {st }}\right.$ century $\left.\mathrm{BC}\right)$, in China and Rome, despite lead being known for millennia before. ${ }^{541,547}$ Over time, depending on availability of lead and application, both lead silicate and lead-alkali silicate glazes (optionally containing alkaline earth) came to be produced, and their advantages over comparable alkali glasses (better wetting, better glass \& hydrolytic stability, lower thermal expansion, higher refractive index \& gloss, easier processing) were well recognised. ${ }^{541,544}$ $\mathrm{Al}_{2} \mathrm{O}_{3}$ was found in significant proportions in most compositions, hinting that ancient glassmakers were already aware of its beneficial effect on glass stability; ${ }^{81}$ in fact, some modern TFR boron-free glasses bear a striking similitude to these ancient glazes (Table 25, Tit-T5 vs. Table 1, Pru-F8, summing $\mathrm{Pb}+\mathrm{R} 2$ ). Lead was used only in glazing (or small objects) at this stage, however, with more classical glasses already having composition very similar to that of modern container glass (see Krk-1/3/5). This restriction was probably due to the leaded glasses being very aggressive towards the crucibles owing to the high fluxing ability of $\mathrm{PbO}$, an issue hindering large-scale fabrication by standard glass melting that is well documented in early studies. ${ }^{536-538}$

The 1600s saw the publication of Antonio Neri's monumental book on glass technology, L'Arte Vetraria (1612); this work was widely expanded, commented and translated in the following century, ${ }^{536}$ reflecting the technological advances in European glass production. The end of the $17^{\text {th }}$ century saw the large-scale introduction and expansion of leaded "crystal" glass, first in England, then in whole Europe. ${ }^{5}$

In contrast, to lead, the intentional use of bismuth is relatively recent, dating from 1400s Renaissance Europe, being mentioned in trading and mining concession documents shortly before $1500 \mathrm{AD} ;{ }^{548}$ documented identification of bismuth extraction techniques is be found in Agricola's Bermannus ${ }^{549}$ and De Re Metallica, ${ }^{535}$ where its mining and separation are described. Bismuth was most likely used in early type alloys, as exemplified from a 1568 description of the type founder trade (Der Schrifftgießer): ${ }^{550}$
Ich geuß die Schrifft zu der Druckrey
I cast the type for printing
Gemacht auß Wißmat / Zin und Bley
Made from bismuth, tin and lead 
Around similar times, Bi also appeared in some renaissance Italian glazes, albeit in small amounts, as a component of lustre, e.g. colour induced by nanoparticles precipitated out of the glass matrix during reduction firing. ${ }^{551}$ In this case, the precipitated phase was cosalite, $\mathrm{Pb}_{2} \mathrm{Bi}_{2} \mathrm{~S}_{5}$, and there is no indication $\mathrm{Bi}$ was added for glassmaking per se. However, in a more recent glass-making manual by Zimmermann (undated, ca. 1700, included in the expanded French translation of L'Arte Vetraria ${ }^{536}$ ), the inclusion of $\mathrm{Bi}_{2} \mathrm{O}_{3}$ in cobalt blue glazes is recommended to enhance their aspect, presumably due to its fluxing role and convenient simultaneous presence in that particular ore.

The first rigorous accounts of scientific experiments on $\mathrm{Bi}$ date from the $18^{\text {th }}$ century, exemplified by the work of Geoffroy the Younger, building on the previous studies of Pott, ${ }^{537}$ who noted considerable similitude with lead in both the metallic and oxide (herein described as "chaux" - i.e. "lime") forms:

1) Low melting point as a metal

2) Weight gain upon "calcination", i.e. oxidation in air

3) Ready vitrification to a glass "without addition"

4) As a glass, strong "erosion of crucibles", but somewhat lower than with lead

5) Slow crystallisation of the glass to "massicot" in 2 hours

6) Aptitude of the glass to vitrify and entrain base metal oxides out of precious metal ores during cupellation

Geoffroy also noted the main difference between bismuth and lead metal, e.g. the brittleness of bismuth. Observations 3-6 are interesting for glass formation. For (3), although we now know that vitrification of pure $\mathrm{PbO}$ and $\mathrm{Bi}_{2} \mathrm{O}_{3}$ does not occur in pure form, and that Geoffroy's samples were therefore - unsurprisingly for that time - contaminated, his findings nevertheless demonstrate the unusually strong glass-forming properties of these compounds, which were to be rigorously investigated for $\mathrm{Bi}_{2} \mathrm{O}_{3}$ by Heynes and Rawson only ca. 200 years later. $^{244}$ This good ability for vitrification is compounded by the apparently low tendency of the formed glasses to crystallise (5) and the strong fluxing ability, i.e. solubility of other oxides to form low-melting glasses ( 4 \& 6).

Bismuth, however, was not used significantly in glass until the middle of the $20^{\text {th }}$ century, when it was introduced in the formulation of metallisations (see section 4.5). This is easily attributed to lead being much better known and more available, having even higher fluxing power in glass and not yet being a major health concern there (leaded petrol and interior paint being much more pressing issues - see next section).

Around 1800, astronomy was a major driving force for the development of technical glasses, which culminated in the experiments of Faraday, ${ }^{538}$ who developed both $\mathrm{PbO}-\mathrm{B}_{2} \mathrm{O}_{3}-\mathrm{SiO}_{2}$ glasses and manufacturing techniques to ensure large, homogeneous and quite colour-free melts. His preferred glass composition is quite similar, somewhat lower-melting, to the main low-firing TFR composition developed by our group (Table 25 - Krk-7 vs. L-V6), the main difference being the absence of $\mathrm{Al}_{2} \mathrm{O}_{3}$.

The end of the $19^{\text {th }}$ century saw massive developments in glass technology, which, among others, led to the development of low-melting leaded "solder" glasses. ${ }^{10-12,14-17,19} \mathrm{An}$ overview of the investigated compositions since this period is given by Mazurin. ${ }^{552,553}$ 


\subsection{Awareness of lead as a toxic substance}

Although health problems related to lead have been mentioned throughout antiquity and the middle ages, ${ }^{539,540,545,546}$ their precise cause was not always well identified. This stems from many factors: lack of knowledge of chemistry, generally poor health and the presence of several toxic elements besides lead, such as mercury, arsenic and cadmium, especially in mining. For example, Agricola ${ }^{535}$ specifically mentions the toxic effects of mines in general on workers and the adjacent environment (he even mentions the latter as a useful hint when searching for a metalliferous vein!), but in most cases does not precisely identify harmful substances, except for vermilion (HgS); his mention of some types of cadmia and pompholyx (zinc minerals) being toxic probably stems more from the variable content of lead or cadmium associated with the relatively harmless zinc. Several ancient authors did however warn against ingestion of leaded compounds such as minium $\left(\mathrm{Pb}_{3} \mathrm{O}_{4}\right)$, ceruse $\left(2 \mathrm{PbCO}_{3} \cdot \mathrm{Pb}(\mathrm{OH})_{2}\right)$ and litharge $(\mathrm{PbO})$, and drinking water from leaded pipes. ${ }^{89,539,546}$ This, however, did not deter the ancient Romans from making heavy use of sapa contaminated with lead acetate $\mathrm{Pb}\left(\mathrm{CH}_{3} \mathrm{COO}\right)_{2}$, also known as sugar/salt of Saturn in ancient texts - as a sweetener and preservative for food and wine, resulting in widespread intoxication; contamination resulted from boiling down the sapa in lead kettles. ${ }^{89,539,540,546}$ The ban on lead-containing sapa, first enacted by several authorities in the 1400 s, was actually one of the first legal restrictions against lead use, but the use of lead-adulterated drinks, as well as that of lead compounds in medicine to combat infections (not so surprising given the paucity of alternatives at this time), continued into the $19^{\text {th }}$ century. 539,540

Nevertheless, firm evidence of the toxic effects of lead came to be clearly established in the 1800 s, as attested by the comprehensive 1839 treatise on lead poisoning by Tanquerel des Planches, ${ }^{539}$ based on his own observations of patients, animal experiments and an extensive literature survey. As awareness of this rose, lead came to be progressively removed from interior paint and canned food. Nonetheless, use of lead continued to rise, culminating in its widespread diffusion, from 1923 on, into the atmosphere through the addition to petrol (USA: gasoline) of tetraethyl lead, $\mathrm{Pb}\left(\mathrm{CH}_{2} \mathrm{CH}_{3}\right)_{4}$, as an anti-knock and engine valve seat protection agent. This source alone dominated the average human exposure to lead for the next decades, until its progressive phase-out from the 1970 s onward. ${ }^{89,540,546,554}$ Now that tetraethyl lead is banned in all developed countries, older contaminants such as interior leaded paints have again become a dominant issue in some countries such as the USA, where the ban came relatively late (1978), and are the subject of controversy and litigation, namely over the opportunity to systematically remediate homes or simply keep the old paints safe (e.g. "leadfree" vs. "lead-safe") and the degree of accountability of present and former leaded paint manufacturers. ${ }^{545,555,556}$ Auto batteries, the dominant application of lead nowadays, are not considered an important source of exposure provided they are handled and recycled properly.

With lead now also banned from large-scale application in electronic solders (specialised applications remain allowed), ${ }^{171,173}$ lead in glass has come under more focus (section 1.4), due to the ongoing controversy over the subclinical effects of very low lead exposure levels, i.e. subtle alterations of cognitive behaviour, especially of children. ${ }^{89,545,557}$ The resulting trend towards further decreasing lead exposure is one of the major motivations for the development of many of the bismuth-based glasses reviewed in the present work. 
Table 24. Timeline of lead- $\&$ bismuth glass development

\begin{tabular}{|c|c|}
\hline$\approx 10000 \mathrm{BC}$ & $1^{\text {st }}$ ceramic materials (pottery) \\
\hline$<3500 \mathrm{BC}$ & Lead (metal) first used ${ }^{89}$ \\
\hline$\approx 3000 \mathrm{BC}$ & First glassy materials (glazes, faience) ${ }^{542,543}$ \\
\hline$\approx 1500 \mathrm{BC}$ & First bulk glasses; extension of available colour range ${ }^{542,543}$ \\
\hline$\approx 300 \mathrm{BC}-$ & First leaded glazes and small glass objects in China and Rome ${ }^{541,547}$ \\
\hline$\approx 100 \mathrm{BC}$ & Widespread use of - and intoxication by - lead in ancient Rome ${ }^{540}$ \\
\hline $1000 \mathrm{AD}$ & Lead-alkali tin-opacified glazes in the Middle East ${ }^{541,544}$ \\
\hline \multirow[t]{3}{*}{$1400 \mathrm{~s}$} & Bi mined specifically, used in typesetting ${ }^{535,548,550}$ \\
\hline & $\mathrm{Bi}$ in glass lustre, as cosalite $\left(\mathrm{Pb}_{2} \mathrm{Bi}_{2} \mathrm{~S}_{5}\right)^{551}$ \\
\hline & $\begin{array}{l}\text { First local bans of sapa made in lead kettles, i.e. containing lead acetate, } \\
\text { in wine }{ }^{540}\end{array}$ \\
\hline $1500 \mathrm{~s}$ & Documentation of Bi mining and extraction ${ }^{535,549}$ \\
\hline $1600 \mathrm{~s}$ & $\begin{array}{l}\text { L'Arte Vetraria (1612), extensively expanded, commented and translated; } \\
\text { beginning of bulk lead "crystal" glass } 5,536\end{array}$ \\
\hline \multirow[t]{2}{*}{$1700 \mathrm{~s}$} & Inclusion of Bi mentioned in cobalt blue glaze making ${ }^{536}$ \\
\hline & $\begin{array}{l}\text { Many studies linking the use of lead tools in the elaboration of drinks } \\
\text { with disease, and assorted bans on this practice }\end{array}$ \\
\hline 1757 & $\begin{array}{l}\text { Scientific experiments on } \mathrm{Bi}^{537} \text {, including } 1^{\text {st }} \text { vitrification of } \mathrm{Bi}_{2} \mathrm{O}_{3} \text { (most } \\
\text { probably contaminated by } \mathrm{SiO}_{2} \text { ) }\end{array}$ \\
\hline 1800 (ca.) & $\begin{array}{l}\text { Systematic studies on optical flint glass; crown-flint achromatic pairs }{ }^{5} \\
\text { Bismuth compounds first used in medecine } 558,559\end{array}$ \\
\hline 1830 & Publication of Faraday's experiments on $\mathrm{PbO}-\mathrm{B}_{2} \mathrm{O}_{3}-\mathrm{SiO}_{2}$ optical glass ${ }^{5,538}$ \\
\hline 1839 & Extensive treatise on lead-induced diseases ${ }^{539}$ \\
\hline \multirow[t]{2}{*}{1900 (ca.) } & Very wide range of technical glasses ${ }^{5}$ \\
\hline & First bans of lead in interior paint (France, Belgium, Austria) ${ }^{546}$ \\
\hline 1923 & Tetraethyl lead introduced in petrol ${ }^{546,554}$ \\
\hline 1945 & $\mathrm{Bi}_{2} \mathrm{O}_{3}$ used in metallisation patent ${ }^{283}$ \\
\hline \multirow[t]{3}{*}{1960 (ca.) } & Basic studies of $\mathrm{Bi}_{2} \mathrm{O}_{3}$ glasses ${ }^{129,244-246}$ \\
\hline & $1^{\text {st }}$ lead-free Bi-based glass, with alcalis ${ }^{285}$ \\
\hline & Discovery of massive lead contamination through petrol ${ }^{546,554}$ \\
\hline $1970 \mathrm{~s}$ & $\begin{array}{l}\mathrm{Bi}_{2} \mathrm{O}_{3} \text { in "standard" AgPd thick-film metallisations, such as DP } 9473 \\
\text { Start of phase-out of leaded petrol }\end{array}$ \\
\hline 1980 & First low-melting, alkali- \& Pb-free glasses based on $\mathrm{Bi}_{2} \mathrm{O}_{3}{ }^{289-294,452}$ \\
\hline \multirow[t]{2}{*}{$1990 \mathrm{~s}$} & Widespread introduction of $\mathrm{Pb}$-free glasses \\
\hline & $\mathrm{Bi}_{2} \mathrm{O}_{3}$ gains importance in glass research (since $\left.1980 \mathrm{~s}\right)^{553}$ \\
\hline 2002 & EU RoHS directive passed ${ }^{171}$ \\
\hline 2003 & Bi proven to be (very slightly) unstable - no practical significance ${ }^{560}$ \\
\hline 2006 & EU RoHS directive in force - use of lead prohibited with exemptions ${ }^{173}$ \\
\hline
\end{tabular}


Th. Maeder - IMR 2012 - Review of $\mathrm{Bi}_{2} \mathrm{O}_{3}$-based glasses (supplements, 9.10.2012) - 88

Table 25. Historical oxide glass compositions on a cation basis. $\mathrm{R} 1=\mathrm{Na}+\mathrm{K}$; $\mathrm{R2}=\mathrm{Mg}+\mathrm{Ca}[+\mathrm{Cu}] ; \mathbf{R 3}=\mathrm{Al}[+\mathbf{F e}+\mathrm{Mn}]$. Modern glasses in italic.

\begin{tabular}{ccccccccc}
\hline Code & R1 & $\mathbf{R 2}$ & $\mathbf{R 3}$ & $\mathbf{P b}$ & $\mathbf{B}$ & Si & Other & Note \\
& {$[\%]$} & {$[\%]$} & {$[\%]$} & {$[\%]$} & {$[\%]$} & {$[\%]$} & {$[\%]$} & \\
\hline Krk-1 $^{5}$ & 29.0 & 8.2 & 4.2 & - & - & 58.0 & $0.6 \mathrm{~S}$ & Egypt, 1500 BC \\
Krk-3 $^{5}$ & 27.2 & 8.9 & 3.1 & - & - & 61.0 & & Sudan, $\approx 250$ AD \\
Krk-5 $^{5}$ & 23.7 & 10.4 & 1.9 & - & - & 64.0 & & Container glass \\
Krk-6 & 22.2 & 11.1 & - & - & - & 66.7 & & "Std." soda-lime \\
Krk-7 & - & - & - & 34.4 & 47.3 & 18.2 & & Faraday, optical \\
L-V6 & & & 4.3 & 36.8 & 31.5 & 27.4 & & Low-firing TFR \\
Tit-T5 & 1.2 & 5.5 & 6.6 & 30.3 & & 56.5 & & Glaze $\dagger$ \\
Pru-F8 & - & - & 2.3 & 36.3 & & 61.4 & & TFR glass \\
\hline
\end{tabular}

${ }^{\dagger}$ Ref. 909.38.5 in original work

\section{Toxicity of elements in glasses}

This section gives a small comparison of the respective toxicity of different elements found in oxide (and some chalcogenide) glasses. Oxides of $\mathrm{Na}, \mathrm{K}, \mathrm{Mg}, \mathrm{Ca}, \mathrm{Al}, \mathrm{Si}$ and $\mathrm{P}$ are of essentially no concern, and therefore are not included.

Table 26 gives an overview of element / representative compound toxicological data, based on indications gathered from product datasheets and governmental / international agencies such as the USA Agency for Toxic Substances Disease Registry (ATSDR), the United Nations (UN) World Health Organisation (WHO) and the latter's International Agency for Research on Cancer (IARC). Especially, comprehensive toxicological profiles from the ATSDR were examined, ${ }^{557,561-569}$ as well as WHO drinking water recommendations. ${ }^{570}$

The acronyms PEL, TLV and REL are related air contamination levels, given by different USA governmental agencies. Here, the values are expressed as "TWA", i.e. time-weighted averages over a $40 \mathrm{~h}$ workweek.

- PEL (permissible exposure limit): maximum allowed exposure level in workplace air (8-hour average), as defined by the Occupational Safety and Health Administration (OSHA), i.e. the legally binding limit in the USA

- TLV (threshold limit value): maximum level, as recommended by the American Conference of Governmental Industrial Hygienists (ACGIH)

- REL (recommended exposure limit): maximum level, as recommended by the National Institute of Occupational Safety and Health (NIOSH)

The TLV and REL values may be lower than the legally binding PEL, if the corresponding agencies feel the latter does not fully guarantee a risk-free environment.

The permissible level in water is that recommended by the WHO for drinking water unless indicated otherwise.

The MSDSs (material safety datasheets) ${ }^{571}$ were taken for relatively neutral compounds, selected to avoid extra hazards not pertinent to glassmaking, i.e. reactivity in the metallic state 
or excessive basicity as an oxide (especially applies to $\mathrm{Sr}$ and $\mathrm{Ba}$ ). Also, multiple entries are given for compounds whose toxicity strongly depends on oxidation state (As and $\mathrm{Sb}$, another well-known example being $\mathrm{Cr}$ ).

Based on this information, one can roughly classify the elements according to a decreasing order of concern:

- Cadmium and arsenic must clearly be avoided, as their toxicity is much higher than that of other substances (a very low level of As might be acceptable as a fining agent).

- Lead is next in line, especially given its tendency to bioaccumulate and apparently low subclinical toxicity threshold (see previous section).

- Vanadium, often touted as a "safe" replacement of lead for low-melting glasses, can actually pose a strong health concern, given its toxicity. However, the main hazard from completed glass seals would be water leaching, and the tolerable $\mathrm{V}$ concentration in water is much higher than that for $\mathrm{Pb}$. These considerations are reinforced by the abundance of $\mathrm{V}$, and its natural presence in the human body (although it has no apparent biological role in humans, it is an essential element for some organisms), and apparent non-toxicity at moderate levels. ${ }^{565,572-574}$ Therefore its use as a relatively lowlevel additive in glass is not a cause of concern.

- Selenium, akin to V, is quite toxic, but is not expected to be used in large amounts, especially in Bi-based oxide glasses; also, it is an essential trace element, ${ }^{569,573}$ and therefore should not pose concern in practice, unless for glasses rich in $\mathrm{SeO}_{2}$.

- Barium, antimony, molybdenum and tungsten, while toxic in high amounts, are not a cause of concern at the low levels expected to result from glass leaching. Mo is actually an important trace element, ${ }^{573}$ and $\mathrm{Sb}$, in spite of its similitude with As, is much less toxic and actually used in medication; ${ }^{567,575-579}$ expected use in glasses is mainly at a low level $(<1 \%)$, as a fining agent (section 3.4), although higher levels can be used given the good glass-forming characteristics of $\mathrm{Sb}_{2} \mathrm{O}_{3}{ }^{327}$

- According to recent research, bismuth is much less toxic than lead, ${ }^{580,581}$ and, though recently proven to be radioactive, its half life of $2 \cdot 10^{19}$ years allows its consideration as stable for all practical purposes. ${ }^{560} \mathrm{Bi}$ has a long been used in medication, and is still widely applied for this purpose, ${ }^{558,559,579,582,583}$ with a good safety record at the prescribed dosages.

- Strontium, niobium and tantalum apparently have very low toxicity. ${ }^{561,584-586} \mathrm{Sr}$ is a good partial or total substitute for more toxic $\mathrm{Ba}$, although somewhat less polarisable, and $\mathrm{Nb} / \mathrm{Ta}$ are useful in some glass formulations. ${ }^{113,216,301,364}$

- Tellurium, in spite of it having no known biological function, has apparently low toxicity, ${ }^{587}$ which is fortunate, as it is an important component in specialised "heavy" glasses (see section 5.1).

- Boron is a somewhat particular case, given the apparently conflicting classification of $\mathrm{B}_{2} \mathrm{O}_{3}$ and $\mathrm{H}_{3} \mathrm{BO}_{3}$ as "toxic", coupled with very high permissible levels. The classification as toxic stems from the reproductive toxicity of very high levels of ingested boron, but significant doses may otherwise be absorbed without problems ${ }^{564}$, 573 , as illustrated by the high permissible levels in air and water and the ubiquity of B in nature. $\mathrm{B}$ is therefore not considered problematic for any reasonably durable glass.

From the above considerations, the use of glasses such as those based on $\mathrm{ZnO}-\mathrm{Bi}_{2} \mathrm{O}_{3}-\mathrm{B}_{2} \mathrm{O}_{3}-$ $\mathrm{SiO}_{2}$ should not pose significant health problems in most applications, i.e. except when 
exposed to very aggressive media or implanted in the body. Nevertheless, toxicity and leaching issues - as well as emissions during manufacturing steps such as glass melting should always be borne in mind when formulating glasses.

Table 26. Toxicological information for different elements found in glasses: air (PEL / TLV / REL) and ambient water exposure levels; carcinogenic potential (IARC) and safety classification according to materials safety datasheet (MSDS) of indicated compound. See text and notes for further clarification.

\begin{tabular}{|c|c|c|c|c|c|c|c|}
\hline $\begin{array}{l}\text { Ele- } \\
\text { ment }\end{array}$ & $\begin{array}{c}\text { PEL } \\
{\left[\mu \mathrm{g} \cdot \mathrm{m}^{-3}\right]}\end{array}$ & $\begin{array}{c}\text { TLV } \\
{\left[\mu \mathrm{g} \cdot \mathrm{m}^{-3}\right]}\end{array}$ & $\begin{array}{c}\text { REL } \\
{\left[\mu \mathrm{g} \cdot \mathrm{m}^{-3}\right]}\end{array}$ & $\begin{array}{l}\text { Water } \\
{\left[\mu \mathrm{g} \cdot 1^{-1}\right]}\end{array}$ & IARC $^{\mathrm{a}}$ & MSDS & $\begin{array}{l}\text { Classifi- } \\
\text { cation }^{\text {b }}\end{array}$ \\
\hline $\mathrm{Sr}$ & I & I & I & $4^{\prime} 000^{d}$ & - & $\mathrm{SrCO}_{3}$ & 1 \\
\hline $\mathrm{Ba}$ & $500^{\mathrm{c}}$ & $500^{c}$ & $500^{\mathrm{c}}$ & 700 & - & $\mathrm{BaCO}_{3}$ & $\mathrm{Xn}$ \\
\hline B & $15^{\prime} 000^{\mathrm{e}}$ & $10^{\prime} 000^{\mathrm{e}}$ & $10^{\prime} 000^{\mathrm{e}}$ & 300 & - & $\mathrm{H}_{3} \mathrm{BO}_{3}$ & $\mathrm{~T}^{\mathrm{f}}$ \\
\hline $\mathrm{V}$ & 100 & 50 & 50 & $100^{\mathrm{g}}$ & $2 \mathrm{~B}$ & $\mathrm{~V}_{2} \mathrm{O}_{5}$ & $\mathrm{~T}, \mathrm{~N}$ \\
\hline $\mathrm{Nb}$ & - & - & - & - & - & $\mathrm{Nb}_{2} \mathrm{O}_{5}$ & $\mathrm{Xi}$ \\
\hline $\mathrm{Ta}$ & - & - & - & - & - & $\mathrm{Ta}_{2} \mathrm{O}_{5}$ & / \\
\hline Mo & - & - & - & 70 & $2 \mathrm{~B}$ & $\mathrm{MoO}_{3}$ & $\mathrm{Xn}$ \\
\hline W & $1^{\prime} 000$ & 1'000 & & - & - & $\mathrm{WO}_{3}$ & $\mathrm{Xn}$ \\
\hline $\mathrm{Cd}$ & 5 & $2^{\mathrm{h}}$ & & 3 & 1 & $\mathrm{CdO}$ & $\mathrm{T}+, \mathrm{N}$ \\
\hline $\mathrm{Pb}$ & 50 & 50 & 50 & 10 & $2 \mathrm{~A}$ & $\mathrm{PbCO}_{3}$ & $\mathrm{~T}, \mathrm{~N}$ \\
\hline As & 10 & 10 & 2 & 10 & 1 & $\begin{array}{l}\mathrm{As}_{2} \mathrm{O}_{3} \\
\mathrm{As}_{2} \mathrm{O}_{5}\end{array}$ & $\begin{array}{c}\mathrm{T}+ \\
\mathrm{T}\end{array}$ \\
\hline $\mathrm{Sb}$ & 500 & 500 & 500 & 5 & $\begin{array}{c}2 \mathrm{~B} \\
-\end{array}$ & $\begin{array}{l}\mathrm{Sb}_{2} \mathrm{O}_{3} \\
\mathrm{Sb}_{2} \mathrm{O}_{5}\end{array}$ & $\begin{array}{l}\mathrm{Xn} \\
\mathrm{Xi}\end{array}$ \\
\hline $\mathrm{Bi}$ & - & - & - & - & - & $\mathrm{Bi}_{2} \mathrm{CO}_{5}$ & - \\
\hline $\mathrm{Se}$ & 200 & 200 & 200 & 10 & 3 & $\mathrm{SeO}_{2}$ & $\mathrm{~T}, \mathrm{~N}$ \\
\hline $\mathrm{Te}$ & - & - & - & - & - & $\mathrm{TeO}_{2}$ & - \\
\hline
\end{tabular}

(a) $1=$ demonstrated carcinogenic; $2 \mathrm{~A} / \mathrm{B}=$ probably/possibly carcinogenic; 3 = not classifiable

(b) $\mathrm{T}+=$ very toxic; $\mathrm{T}=$ toxic; $\mathrm{Xn}=$ harmful; $\mathrm{Xi}=$ irritant; $\mathrm{N}=$ dangerous for the environment

(c) Soluble Ba only; $\mathrm{BaSO}_{4}: 10 \mathrm{mg} / \mathrm{m}^{3}$ (REL/TLV) ; $15 \mathrm{mg} / \mathrm{m}^{3}$ (PEL)

(d) Sr: according to ATSDR ${ }^{561}$

(e) Expressed as $\mathrm{B}_{2} \mathrm{O}_{3}$

(f) Classified toxic due to reproductive effects at much lower doses than that for systemic toxicity

(g) Rough estimate based on $1.8 \mathrm{mg} /$ day intake limit \& $4 \ldots 220 \mu \mathrm{g} / \mathrm{L}$ reported surface water concentration

(h) Expressed as Cd in Cd compounds 


\section{Oxidation state of $\mathrm{Bi}$ species in glasses}

This section discusses the valence of $\mathrm{Bi}$ in oxide glasses, i.e. the existence of species differing from the usual trivalent state. A strong case is made in favour of predominantly reduced species in the case of departure from the nominal $\mathrm{Bi}^{3+}$ valence, and against significant formation of $\mathrm{Bi}^{5+}$ species, as occasionally reported, except possibly in very special cases. Also, the nature of these reduced species is briefly discussed.

\section{Introduction}

In recent work on the optical properties, mainly luminescence, of Bi-containing glasses (both Bi-based and Bi-doped), somewhat conflicting conclusions have been made as to the origin of these phenomena. While most authors clearly seem to favour defects stemming from reduced species $^{353,428,429,588-591}$, others disagree and postulate significant or even dominant amounts of $\mathrm{Bi}^{5+359,360,592-595}$, often basing on the results of XAFS or XPS studies.

\section{Oxide compounds with pentavalent bismuth}

Akin to lead(IV), there are instances where Bi does occur in higher oxidation states than +3 :

- Although isolation of well-defined, stoichiometric, anhydrous $\mathrm{Bi}_{2} \mathrm{O}_{5}$ is exceedingly difficult, ${ }^{596-598}$ compounds such as $\mathrm{BiO}_{2}$ (stoichiometric and nonstoichiometric variants) and $\mathrm{Bi}_{4} \mathrm{O}_{7}^{597-599}$ may be prepared by wet chemical methods - with $\mathrm{Bi}_{4} \mathrm{O}_{7}$ crystallised by heating at high oxygen pressures - and tend to show separate $\mathrm{Bi}^{3+}$ and $\mathrm{Bi}^{5+}$, rather than "average" (delocalised) sites. Decomposition temperatures to mainly trivalent $\mathrm{Bi}_{2} \mathrm{O}_{3}$ are low, lying between 300 and $400^{\circ} \mathrm{C}$, with a small amount of pentavalent $\mathrm{Bi}$ (oxygen excess) possibly persisting in sillenite-type $\beta-\mathrm{Bi}_{2} \mathrm{O}_{3}{ }^{600}$ In comparison, preparation of $\mathrm{PbO}_{2}$ is quite facile, ${ }^{601}$ and the decomposition temperature in air of $\mathrm{Pb}_{3} \mathrm{O}_{4}$ to $\mathrm{PbO}$ is higher, ca. $560^{\circ} \mathrm{C}^{602}$ In oxides, the lower stability of $\mathrm{Bi}^{5+} \mathrm{vs}$. $\mathrm{Pb}^{4+}$ follows the trend set by $\mathrm{As}^{5+}$ vs. $\mathrm{Ge}^{4+}$, and $\mathrm{Sb}^{5+}$ vs. $\mathrm{Sn}^{4+}$ in the periodic table.

- In the synthesis of conductive bismuth noble metal pyrochlores such as $\mathrm{Bi}_{2} \mathrm{Ru}_{2} \mathrm{O}_{7}$ by wet chemical methods, excess Bi may be incorporated, presumably into the "B" site in higher-valence form, nominally yielding the solid solution $\mathrm{Bi}_{2}{ }_{2}^{\mathrm{II}}\left(\mathrm{Ru}, \mathrm{Bi}^{\mathrm{IV}}\right)_{2} \mathrm{O}_{7}$, the same being possible with $\mathrm{Pb}$ to form $\mathrm{Pb}_{2}^{\mathrm{II}}\left(\mathrm{Ru}_{2} \mathrm{~Pb}^{\mathrm{IV}}\right)_{2} \mathrm{O}_{6.5},{ }^{483}$ although there is some doubt about the valence of $\mathrm{Ru}$ (see below). Low-temperature, oxidising conditions were used in this work, i.e. soluble bismuth nitrate salts ${ }^{603}$ and oxygen sparging. In both compounds, about half of the $\mathrm{Ru}$ may be substituted by $\mathrm{Bi}$ or $\mathrm{Pb}$. However, these substituted forms are probably not stable at high temperature, excess $\mathrm{Pb}$ being clearly shown to severely degrade thermal stability ${ }^{483}$ and no significant excess Bi being seen in $\mathrm{Bi}_{2} \mathrm{Ru}_{2} \mathrm{O}_{7}$ prepared by standard calcination. Additionally, there is some doubt about the valence of $\mathrm{Pb}, \mathrm{Bi}$, and $\mathrm{Ru}$, as studies on $\mathrm{Bi}_{3} \mathrm{Ru}_{3} \mathrm{O}_{11}$, which is stable vs. $\mathrm{Bi}_{2} \mathrm{Ru}_{2} \mathrm{O}_{7}$ below $950^{\circ} \mathrm{C}$ in air, tend to attribute the valence increase stemming from the excess oxygen to $\mathrm{Ru},{ }^{460,513,604,605}$ a conclusion that is also supported by the existence of $\mathrm{La}_{3} \mathrm{Ru}_{3} \mathrm{O}_{11},{ }^{606}$ where La is clearly trivalent.

- In crystalline compounds such as perovskites and related structures, studies of the ternary equilibria of $\mathrm{Bi}_{2} \mathrm{O}_{3} / \mathrm{Bi}_{2} \mathrm{O}_{5}$ with alkaline earth oxides show that pentavalent bismuth may be stabilised in the octahedral "B" sites by large alkaline earth "A" cations. Stability is favoured both by large "A" cations and large A:B ratios, i.e. a more basic environment, as attested by systems with $\mathrm{CaO}^{607,608}, \mathrm{SrO}^{609,610}$, and $\mathrm{BaO}^{611}$. With $\mathrm{CaO}$, only trivalent bismuth is seen under normal oxygen pressures. With SrO, pentavalent bismuth compounds such as $\mathrm{Sr}_{6} \mathrm{Bi}_{4} \mathrm{O}_{15}$ and $\mathrm{Sr}_{6} \mathrm{Bi}_{2} \mathrm{O}_{11}$ do exist at moderate temperatures for $\mathrm{Sr}: \mathrm{Bi}>1$; however, the 1:1 compound yields $\mathrm{Sr}_{2} \mathrm{Bi}_{2} \mathrm{O}_{5}$, with trivalent bismuth only. $\mathrm{BaO}$ has expectedly an even better stabilising effect for 
higher valence of $\mathrm{Bi}$; thus, $\mathrm{BaBiO}_{3}$ may be prepared by standard ceramic methods and is essentially oxygen-stoichiometric below ca. $875^{\circ} \mathrm{C} .{ }^{611,612}$ This is also true of more complex oxides, such as $\mathrm{Ba}\left(\mathrm{In}_{0.5} \mathrm{Ta}_{0.5-\mathrm{x}} \mathrm{Bi}_{\mathrm{x} \leq 0.05}\right)^{613}, \mathrm{Sr}_{2} \mathrm{BiNdO}_{6}{ }^{614} \mathrm{Ba}_{2} \mathrm{BiYO}_{6}$ and $\mathrm{Ba}_{2} \mathrm{BiDyO}_{6}{ }^{615}$ Again, a strong similitude with lead may be noted, as stabilisation of tetravalent lead is also seen in the corresponding compounds with the alkaline earth oxides, ${ }^{66,616-620}$ and tendencially occurs more readily than for higher Bi oxidation states. Going even further, one can observe that such stabilisation of "unusual" higher oxidation states by large alkaline and alkaline earth ions (or in some cases by $\mathrm{Pb}^{2+}$ or $\mathrm{Bi}^{3+}$ ) is also found for many polyvalent transition metal oxide compounds, yielding species such as $\mathrm{Cr}^{4+/ 6+}, \mathrm{Mn}^{4+}, \mathrm{Fe}^{4+}, \mathrm{Co}^{3+/ 4+}, \mathrm{Ni}^{3+}$ and $\mathrm{Cu}^{2+/ 3+}$. 444, 621-624

- Single alkalis have a lower stabilising effect on pentavalent bismuth than alkaline earths in oxide compounds; substances such as $\mathrm{NaBiO}_{3}, \mathrm{KBiO}_{3}$, or $\left(\mathrm{Ba}_{1-x} \mathrm{~K}_{x}\right) \mathrm{BiO}_{3}$ with $x$ above $\sim 0.5$, require wet chemical synthesis, ${ }^{596}$ high-pressure conditions, ${ }^{625}$ or anodic electrodeposition. ${ }^{626}$ Compounds with a more basic stoichiometry such as $\mathrm{Na}_{3} \mathrm{BiO}_{4}$ may be prepared by more classical routes, albeit at moderate temperatures $\left(600^{\circ} \mathrm{C}\right.$ in $1 \mathrm{~atm} \mathrm{O}_{2}$, then $700^{\circ} \mathrm{C}$ in sealed capsules). ${ }^{627}$ In all cases, reported synthesis or decomposition temperatures under ambient pressures are below ca. $900^{\circ} \mathrm{C}$.

- The pure compound $\mathrm{Bi}_{2} \mathrm{O}_{3+x}$ itself is reported to be slightly oxygen-deficient $(x=-0.033)$ in the melt equilibrated with air at $895^{\circ} \mathrm{C}$, and also in the different crystalline polymorphs. ${ }^{628}$ Detailed structural studies on metastable $\gamma-\mathrm{Bi}_{2} \mathrm{O}_{3}{ }^{629}$ and other similar compounds, ${ }^{630}, 631$ which have a defective sillenite structure, also indicated $\mathrm{Bi}^{5+}$ to be essentially absent, the formal higher charge of the tetrahedral sites being compensated by oxygen vacancies making space for the "too large" $\mathrm{Bi}^{3+}$ cation and its "lone pair" electrons. On the other hand, for solid oxygen-ion electrolytes consisting of the high-temperature cubic $\delta$ - $\mathrm{Bi}_{2} \mathrm{O}_{3}$ phase stabilised by $20-50 \mathrm{~mol} \%$ $\mathrm{Er}_{2} \mathrm{O}_{3}$, a slight oxygen excess, $x=+0.005$ to +0.022 , depending on the $\mathrm{Er}_{2} \mathrm{O}_{3}$ content, has been reported in air around $800^{\circ} \mathrm{C},{ }^{632}$ in agreement with the results for similar $\mathrm{Bi}_{2} \mathrm{O}_{3}-\mathrm{Y}_{2} \mathrm{O}_{3}$ and with the conductivity being p-type in ambient air. ${ }^{519,521}$ However, this represents at most a small oxygen excess, and the possibility this may be due to impurities cannot be totally excluded, given the rather high reactivity of $\mathrm{Bi}_{2} \mathrm{O}_{3}$ with other oxides.

\section{Pentavalent bismuth in glasses?}

Clearly, the above examples indicate that, in traditional high-temperature (above ca. $900^{\circ} \mathrm{C}$ ) synthesis, $\mathrm{Bi}^{5+}$ occurs only in rather special circumstances: very basic environments, not too high temperatures and high oxygen pressures. In glasses prepared from the melt, significant amounts of $\mathrm{Bi}^{5+}$ species, if any, would therefore only be expected to occur in compositions very rich in alkalis (alkaline earth oxides require higher melting temperatures), stabilised by minimal amounts, if at all, of $\mathrm{B}_{2} \mathrm{O}_{3}$ and $\mathrm{SiO}_{2}$. An example of such compositions is the $\mathrm{Li}_{2} \mathrm{O}-$ $\mathrm{Bi}_{2} \mathrm{O}_{3}$ system, ${ }^{388,389}$, with optional $\mathrm{BaO},{ }^{381} \mathrm{PbO}^{382}$ or small $\mathrm{B}_{2} \mathrm{O}_{3}{ }^{334}$ additions, and "excess oxygen" has indeed been reported in these glasses at high $\mathrm{Li}_{2} \mathrm{O}$ concentrations, ${ }^{388}$ but such compositions are very atypical and would find limited practical uses due to their moisture sensitivity.

Less basic conditions rapidly destabilise $\mathrm{Bi}^{5+}$, as attested by the results of adding $\mathrm{B}_{2} \mathrm{O}_{3}$ to the $\mathrm{BaO}-\mathrm{Bi}_{2} \mathrm{O}_{3}$ system ${ }^{347,351,611,633}$ : the higher $\mathrm{Bi}$ valence seen in $\mathrm{BaBiO}_{3}$ is no longer found in the compositionally closest compounds, $\mathrm{BaBiBO}_{4}$ and $\mathrm{Ba}_{3} \mathrm{BiB}_{3} \mathrm{O}_{9}$, which essentially contain $\mathrm{Bi}^{3+}$ only.

This view is also confirmed by the electrochemical series determined for a more traditional, but still quite alkali-rich, $\mathrm{Li}_{2} \mathrm{O}-\mathrm{Na}_{2} \mathrm{O}-\mathrm{MgO}-\mathrm{B}_{2} \mathrm{O}_{3}-\mathrm{SiO}_{2}$ glass ${ }^{424}$. Even at the relatively 
moderate temperature of $1100^{\circ} \mathrm{C}, \mathrm{Bi}^{5+}$ is not found; the equilibrium in air lies ca. at the $\mathrm{Sb}^{5+} / \mathrm{Sb}^{3+}$ boundary, so a significant amount of $\mathrm{Bi}^{5+}$, which is much less stable than $\mathrm{Sb}^{5+}$, would only be expected at higher oxygen pressures, lower temperatures and more alkali-rich glasses (stabilisation of oxidised species by alkalis is illustrated by the comparison of their redox potential in two different $\mathrm{Na}_{2} \mathrm{O}-\mathrm{SiO}_{2}$ glass melts ${ }^{634}$ ). Recent sol-gel experiments on insertion of $\mathrm{Bi}$ metal, oxide and sulphide nanoparticles into a $\mathrm{Na}_{2} \mathrm{O}-\mathrm{B}_{2} \mathrm{O}_{3}-\mathrm{SiO}_{2}$ glass $(\mathrm{Na}: \mathrm{B}: \mathrm{Si}$ $\approx 2: 6: 9)^{534}$, although performed at moderate temperatures $\left(400-600^{\circ} \mathrm{C}\right)$ in oxygen, did not lead to detected formation of $\mathrm{Bi}^{5+}$ species (it must be noted that the particular experimental procedure somewhat limited the interaction of $\mathrm{Bi}$ species with the glass). This is not surprising, given the well-known low stability towards reduction of $\mathrm{Bi}_{2} \mathrm{O}_{3}$, both pure and in compounds, ${ }^{421,422,424,519-521,635}$ also attested by its easy precipitation from glass as metal particles upon exposition to a reducing gas at moderate temperatures. ${ }^{366,408,425,534,636}$

\section{Nature of reduced species in $\mathrm{Bi}_{2} \mathrm{O}_{3}$-containing glasses}

Detailed investigations on the origins of the intense colouration and near-infrared (NIR) luminescence of bismuth glasses clearly show they are correlated ${ }^{637}$ and both stem from the presence of reduced species introduced by corresponding conditions: acidic melts, ${ }^{375,426,588}$ high temperatures, ${ }^{118,353,375,426,591,637}$ low oxygen pressures, ${ }^{591}$ using reducing starting reagents or introduction of small amounts of $\mathrm{Bi}$ metal. ${ }^{426,637} \mathrm{~A}$ direct confirmation is the presence of metallic $\mathrm{Bi}$ nanoparticles in the more reduced glasses, as evidenced by SEM, TEM and XRD. ${ }^{118,353,361,426,427}$ Conversely, classical fining agents (i.e. that act as redox buffers, preventing excessive reduction) such as $\mathrm{Sb}_{2} \mathrm{O}_{3}, \mathrm{As}_{2} \mathrm{O}_{3}$ and $\mathrm{CeO}_{2}$ efficiently suppress both. ${ }^{118,273,353,361,638}$ Coloration and nanoparticles formation may also be suppressed by additives that generate oxygen in the melt such as $\mathrm{KNO}_{3}$ and $\mathrm{KClO}_{4}{ }^{4}{ }^{47}$

While these facts establish that the aliovalent species in glasses (except possibly the abovementioned very alkaline, low-temperature melts) are reduced with respect to the usual $\mathrm{Bi}^{3+}$ state, the exact nature of the intermediate species, if any, between $\mathrm{Bi}^{0}$ metallic nanoparticles and $\mathrm{Bi}^{3+}$ still is vividly debated, based on chemical, structural and luminescence studies; species such as $\mathrm{Bi}^{2+},{ }^{429,588} \mathrm{Bi}^{+},{ }^{637}$ subvalent polycations, ${ }^{591,637}$ or even dissolved $\mathrm{Bi}^{0}$ atoms or clusters ${ }^{353}$ have been postulated, in line with species found in molten salt solutions. ${ }^{639}$ It must also be borne in mind that the glasses are far out of equilibrium (possibly incomplete equilibration of the melt with ambient oxygen, rapid cooling after melting, stressrelieving anneal), making the reduced species most likely highly dependent on the preparation conditions.

Concerning the XAFS results ${ }^{595}$ interpreted to show the presence of $\mathrm{Bi}^{5+}$ ions, the overwhelming experimental evidence favouring reduced Bi species in glasses melted at high temperatures calls into question ${ }^{588}$ the use of X-ray absorption data to determine valence: the information returned, i.e. bond length and coordination, cannot be used alone to unambiguously determine the exact valence of $\mathrm{Bi}$, especially in the light of the strong tendency towards local structural disorder.

\section{Conclusions}

The experimental evidence confirms the presence of reduced (valence $<3$ ) Bi species as the source of colour and luminescence in most cases: such properties are favoured by reducing conditions: high melting temperatures, absence of fining agents, reducing atmospheres and a more acidic glass chemistry, culminating in the precipitation of $\mathrm{Bi}^{0}$ metallic nanoparticles. Most practical glasses will have a chemistry similar to those where such phenomena are observed (with additions such as fining agents to suppress their occurrence when transparency 
is sought). Therefore, the existence of significant amounts of pentavalent bismuth is deemed very unlikely in most melt-derived glasses.

On the other hand, the presence of some $\mathrm{Bi}^{5+}$ in very basic melts at moderate temperatures cannot be totally ruled out, nor in glasses prepared by "unconventional" low-temperature methods such as sol-gel synthesis or thin-film deposition.

The chemistry of the reduced species present in Bi glasses - other than $\mathrm{Bi}^{0}$ particles - has not at present been fully understood; more detailed work is clearly needed to elucidate how these species form, as a function of the degree of reduction of the melt and the subsequent cooling and annealing phases.

\section{Coordination of bismuth in crystalline oxides}

In the aim to provide insight into the structure of $\mathrm{Bi}_{2} \mathrm{O}_{3}$-based glasses, this section shortly reviews the coordination of bismuth in crystalline oxides, concentrating on those oxides having the most relevance for glass formation, i.e. mixed compounds of $\mathrm{Bi}_{2} \mathrm{O}_{3}$ ( $\mathrm{Bi}$ essentially trivalent) with the classical glass-forming oxides. Pure or near-pure $\mathrm{Bi}_{2} \mathrm{O}_{3}$, as well as conducting compounds such as $\mathrm{Bi}_{2} \mathrm{Ru}_{2} \mathrm{O}_{7}$, are also treated. It is shown that due to its stereochemically active "lone-pair" electrons, $\mathrm{Bi}^{3+}$ oxygen coordination polyhedra exhibit a wide array of disordered and asymmetrical geometries, even in crystalline compound. As expected, similar behaviour is seen in the other "lone-pair" ions $\mathrm{Pb}^{2+}$ and $\mathrm{Sn}^{2+}$.

\section{Introduction}

The concept of ionic radii, as published in the tables by Shannon, ${ }^{640}$ has been mostly very helpful in the study of ceramic structures. However, even at the time of publication (1976), Shannon noted that some cations posed considerable problems when considering them as spheres: $\mathrm{Pb}^{2+}$ (somewhat), and especially $\mathrm{Sn}^{2+}$ and $\mathrm{Bi}^{3+}$. He already correctly identified these problems as stemming from their "lone pair" character, derived from outer $s$ states $\left(\mathrm{Sn}^{2+}: 5 s^{2}\right.$; $\mathrm{Pb}^{2+}$ and $\left.\mathrm{Bi}^{3+}: 6 s^{2}\right)$. However, the exact nature of the involved orbital mixing, required for the "lone pair" to become stereochemically active (pure $s$ states have spherical symmetry), has long been elusive. Recent electronic structure calculations and corresponding experiments have shed new light on this matter, yielding a complex picture involving interaction between both $s$ and $p$ orbitals in the metal valence shell, mediated by oxygen $2 p$ ones; these studies were also extended to other lone-pair cations and chalcogenide anions, and good predictions of the appearance or not of a stereochemically active lone pair for a several metalchalcogenide compounds could be made. ${ }^{403,641-643}$ Such a stereochemically active lone pair results in strong bonding asymmetry and attendant structural distortions, which are expected to limit, in this case, the usefulness of simplified concepts such as bond-valence parameters ${ }^{644}$ in calculating the effective bond strengths.

This supplement lists and comments some of the features found in the different structures of crystalline compounds: the oxide, $\mathrm{Bi}_{2} \mathrm{O}_{3}$ (pure and slightly doped), as well as compositions more typical of those found in glasses, i.e. especially borates and silicates. This should yield useful insight on local $\mathrm{Bi}^{3+}$ oxygen coordination polyhedra in glasses. A few salient examples of the coordination polyhedra seen in the crystalline compounds discussed in this supplement are illustrated in Figure 6; the stereochemically active lone pair, denoted "E", may be seen as "repelling" the oxygen atoms in its vicinity, or even as taking the place of a bond, resulting in $\mathrm{Bi}\left(\mathrm{O}_{x} \mathrm{E}\right)$ polyhedra. 


\section{Polymorphism in $\mathrm{Bi}_{2} \mathrm{O}_{3}$}

$\mathrm{Bi}_{2} \mathrm{O}_{3}$ has four common phases, denoted $\alpha, \beta, \gamma$ and $\delta$, of which monoclinic $\alpha-\mathrm{Bi}_{2} \mathrm{O}_{3}$ is stable below $729^{\circ} \mathrm{C}$, and cubic $\delta$ - $\mathrm{Bi}_{2} \mathrm{O}_{3}$ above this temperature, the $\beta$ and $\gamma$ phases being metastable and their obtention possible by light doping, controlled cooling of $\delta$ - $\mathrm{Bi}_{2} \mathrm{O}_{3}$, or lowtemperature chemical synthesis. A fifth $\varepsilon$ phase has recently been grown by a hydrothermal method. ${ }^{515,629,642,645-648}$ Atomic configurations and Bi-O distances are given for the $\alpha, \beta$ and $\delta$ polymorphs, and a common " $\beta$ " ionic conductor phase ${ }^{649}$, in Table 27 . The data for the sillenite compounds (ideally $\mathrm{Bi}_{24} \mathrm{M}_{2} \mathrm{O}_{40}$, where $\mathrm{M}$ is a tetravalent cation), of which $\gamma-\mathrm{Bi}_{2} \mathrm{O}_{3}$ is a defective variant, are listed in Table 28.

$\alpha$ - and $\beta-\mathrm{Bi}_{2} \mathrm{O}_{3}$

Monoclinic $\alpha-\mathrm{Bi}_{2} \mathrm{O}_{3}$, the phase stable in ambient conditions, has two distinct $\mathrm{Bi}$ sites (Bi1 \& $\mathrm{Bi} 2$, respectively with 5 and 6 neighbouring oxygen anions (Table 27 \& Figure 8, good agreement between different sources), with both coordination polyhedra being strongly distorted with respect to their idealised geometry. In the square pyramid around Bi1, the shortest apex bond $(212 \mathrm{pm})$ is almost matched by the bonds on one side of the base $(220 \&$ $221 \mathrm{pm})$, whereas the bonds on the other side of the base are much longer ( $253 \& 263 \mathrm{pm})$. The same is true for the asymmetric octahedron around $\mathrm{Bi} 2$, especially for the three longer bonds, which span a wide range of distances (243-279 pm).

The metastable tetragonal $\beta$ - $\mathrm{Bi}_{2} \mathrm{O}_{3}$ phase, which can be prepared by decomposing $\mathrm{Bi}_{2} \mathrm{O}_{2} \mathrm{CO}_{3}$ at $\approx 380^{\circ} \mathrm{C}^{650}$ or sublimation/condensation, ${ }^{651}$ may be thought of as a distorted and ordered (oxygen vacancies) version of the high-temperature cubic $\delta$ polymorph. ${ }^{650}$ The reported Bi-O distances (Table 27) are in very good agreement, and also similar to that observed for Bi1 in $\alpha-\mathrm{Bi}_{2} \mathrm{O}_{3}$. The oxygen coordination shell around $\mathrm{Bi}$, shown in Figure 14, is a prime example of the difficulty of unambiguously specifying the coordination of $\mathrm{Bi}$, stemming from the strong distortions, wide range of bond lengths and stereochemically active lone pair. Here, several coordination polyhedra may reasonably be considered (see also Figure $6 \&$ Table 14):

- Octahedron: if all oxygen ions and the lone pair E are counted as vertices

- Square pyramid (5-Py14, very deformed): if either $\mathrm{O} 2^{\mathrm{e}}$ or $\mathrm{E}$ is omitted

- Face-sharing trigonal bipyramid (4-BPy): if both $\mathrm{O}_{2}{ }^{\mathrm{e}}$ and $\mathrm{E}$ are omitted

\section{$\delta-\mathrm{Bi}_{2} \mathrm{O}_{3}$}

Cubic $\delta-\mathrm{Bi}_{2} \mathrm{O}_{3}$ is traditionally reported to crystallise in the fluorite $\left(\mathrm{CaF}_{2}\right)$ structure with only $3 / 4$ of oxygen positions filled (Figure 6 ) and the corresponding oxygen vacancies completely disordered. This ideal $\mathrm{Bi}\left(\mathrm{O}_{1.5} \square_{0.5}\right)$ formula suggests a very high oxygen ion conductivity. In practice, both conductivity and entropy are indeed close to that of the liquid phase, ${ }^{646}$ and this material is the best solid oxygen ionic conductor known to date. Although it is stable only at high temperature, $\delta$ - $\mathrm{Bi}_{2} \mathrm{O}_{3}$ or closely related phases may be stabilised to lower temperatures (in the same way as cubic $\mathrm{ZrO}_{2}$ ) by appropriate doping to yield useful ionic oxygen conductors, albeit with lower conductivity than the pure material. ${ }^{519-522,632,651-654}$ More detailed structural studies yielded a somewhat more complicated structure than a simple fluorite lattice with random oxygen vacancies. To account for the observed neutron diffraction data, local shifts of all ${ }^{65}$ or some ${ }^{653}$ of the oxygen anions with respect to their average positions were postulated, with stabilised $\mathrm{Bi}_{2} \mathrm{O}_{3}$ (doped with $27 \% \mathrm{Y}_{2} \mathrm{O}_{3}$ ) exhibiting an even wider variety of possible oxygen displacements. ${ }^{653}$ As the possible dynamic shifts are averaged out over time, the material retains a cubic symmetry overall. However, recent experiments and calculations ${ }^{403,642,643,648,655,656}$ strongly suggest that on an instantaneous and local basis, there is strong departure from the overall symmetry, leading to a coordination 
around $\mathrm{Bi}$ and $\mathrm{Bi}-\mathrm{O}$ distances that strongly resemble that of the ordered $\alpha$ and $\beta$ polymorphs. The exact local structure is still a matter of debate.

\section{$\gamma-\mathrm{Bi}_{2} \mathrm{O}_{3}$ and the sillenite family}

Doping $\mathrm{Bi}_{2} \mathrm{O}_{3}$ with a small amount of oxides of widely varying cation sizes and valences, such as $\mathrm{ZnO}, \mathrm{CdO}, \mathrm{PbO}, \mathrm{B}_{2} \mathrm{O}_{3}, \mathrm{Al}_{2} \mathrm{O}_{3}, \mathrm{Fe}_{2} \mathrm{O}_{3}, \mathrm{Ga}_{2} \mathrm{O}_{3}, \mathrm{Tl}_{2} \mathrm{O}_{3}, \mathrm{TiO}_{2}, \mathrm{ZrO}_{2}, \mathrm{SiO}_{2}, \mathrm{GeO}_{2}, \mathrm{CeO}_{2}$, $\mathrm{V}_{2} \mathrm{O}_{5}, \mathrm{P}_{2} \mathrm{O}_{5}$ and $\mathrm{As}_{2} \mathrm{O}_{5}{ }^{630}, 631,651,652,657,658$ stabilises the body-centred cubic sillenite structure, which is isostructural with the metastable $\gamma$ polymorph of pure $\mathrm{Bi}_{2} \mathrm{O}_{3} .{ }^{629}$ Sillenites are classified as "ideal" if they correspond to the formula $\mathrm{Bi}_{12} \mathrm{MO}_{20}$ (unit cell: $\mathrm{Bi}_{24} \mathrm{M}_{2} \mathrm{O}_{40}$ ), where $\mathrm{M}$ is a smaller tetravalent metal, or "defect" otherwise, the latter category therefore including pure $\gamma-\mathrm{Bi}_{2} \mathrm{O}_{3}{ }^{629,631,659}$.

Two distinct cation sites ("Bi" and "M") exist in the sillenite structure. The oxygen coordination shell around $\mathrm{Bi}^{3+}$ in the Bi site consists of distorted square pyramids (5-Py14, see Figure $6 \&$ Table 14), and the corresponding distances (to apex; to the 4 bases) are given in Table 28. Two oxygen ions lie further, at ca. $300-310 \mathrm{pm}$, and taking them in consideration as well would yield a distorted 7-Py142 structure. ${ }^{629,630,657,659}$ The Bi-O distances are very similar as in the 5-Py14 polyhedra of $\alpha$ - and $\beta-\mathrm{Bi}_{2} \mathrm{O}_{3}$ : the shortest oxygen is $200-210 \mathrm{pm}$ distant and is at the pyramid apex, and the pyramid base is strongly distorted, with one side having only slightly longer bonds than with the apex and the other side much longer ones.

In ideal sillenites, the $\mathrm{M}$ site is filled with cations having a valence of +4 (e.g. $\mathrm{Si}^{4+}$ or $\mathrm{Ge}^{4+}$ ) or a cation mix of same average valence, and surrounded by an oxygen tetrahedron. However, $\gamma-\mathrm{Bi}_{2} \mathrm{O}_{3}$ and sillenites doped at low levels contain $\mathrm{Bi}$ ions in the $\mathrm{M}$ site as well, and analyses have not detected significant amounts of $\mathrm{Bi}^{5+629,631,652,659}$ (see also discussions in the previous section). This implies accommodation of $\mathrm{Bi}^{3+}$ in the much too small tetrahedral $\mathrm{M}$ sites (that accept cations as small as $\mathrm{B}^{3+}$ !), and again illustrates the effect of the lone pair: in this case, $\mathrm{Bi}^{3+}$ takes the $3-\mathrm{PyM}$ configuration (Figure $6 \&$ Table 14), i.e. the nominal $\mathrm{MO}_{4}$ tetrahedron is replaced by $\mathrm{BiO}_{3} \mathrm{E}$, with an oxygen anion replaced by a vacancy "filled" by the $\mathrm{Bi}^{3+}$ lone pair $\mathrm{E}$, accompanied by a local shift of the large $\mathrm{Bi}^{3+}$ cation away from the three remaining oxygen anions. This yields short average Bi-O distances in the 198 to $209 \mathrm{pm}$ range, as determined by neutron diffraction, ${ }^{629,659}$ which is realistic given the fact that there are only 3 bonds. As each $\mathrm{Bi}^{3+}$ at the $\mathrm{M}$ site entails "replacement" of a corresponding oxygen anion by the $\mathrm{Bi}^{3+}$ lone pair $\mathrm{E}$, the general formula for sillenite stoichiometry determined by Valant \& Suvorov ${ }^{631}$ for all $M$ valences may be written $\operatorname{Bi}_{12}\left(\mathrm{Bi}_{0.8-\mathrm{n} \cdot \mathrm{x}} \mathrm{M}^{\mathrm{n}+}{ }_{5 \mathrm{x}} \square_{0.2-(5-}\right.$ n) $\times x)\left(\mathrm{O}_{19.2+\mathrm{n} \cdot \mathrm{x}} \mathrm{E}_{0.8-\mathrm{n} \cdot \mathrm{x}}\right)$, which corresponds to complete occupation of the oxygen sites if the lone pairs $\mathrm{E}$ of the $\mathrm{Bi}^{3+}{ }_{\mathrm{M}}$ cations are taken into account. The very flexible bonding of $\mathrm{Bi}^{3+}$ can also allow some departure from stoichiometry, as required due to charge or size considerations, e.g. cations too large for the M site or interstitial oxygen. ${ }^{629,630}$

\section{Compounds related to glass-forming compositions}

After examining the strong disordering effects of the $\mathrm{Bi}^{3+}$ lone pair on pure or doped $\mathrm{Bi}_{2} \mathrm{O}_{3}$, we now turn to compositions more relevant to our main subject, i.e. compounds of $\mathrm{Bi}_{2} \mathrm{O}_{3}$ with glass-forming oxides such as $\mathrm{B}_{2} \mathrm{O}_{3}, \mathrm{SiO}_{2}, \mathrm{GeO}_{2}$ and $\mathrm{P}_{2} \mathrm{O}_{5}$. The coordination around $\mathrm{Bi}^{3+}$ for some compounds is listed in Table 29. For comparison purposes, the same is given around $\mathrm{Pb}^{2+}$ in Table 30, and $\mathrm{Sn}^{2+}$ in Table 31, and around other cations in Table 32, for analogous compounds. Finally, the coordination shells around $\mathrm{B}^{3+}$ are listed for examined compounds in Table 33, and those around $\mathrm{Si}^{4+}, \mathrm{Ge}^{4+}$ and $\mathrm{P}^{5+}$ is given in Table 34.

The tendency for disorder and asymmetry around $\mathrm{Bi}^{3+}$, seen in pure and doped $\mathrm{Bi}_{2} \mathrm{O}_{3}$, is confirmed in the compounds with the glass-forming oxides, with a very rich variety of oxygen coordination shells (even in a single compound such as $\mathrm{Bi}_{4} \mathrm{~B}_{2} \mathrm{O}_{9}{ }^{660}$ ), and often three bonds 
significantly shorter than the rest, as in the idealised 6-Oct33 structure. Three shorter bonds are also often seen for nominally different coordinations (e.g. 4-PyM \& 5-Py14), resulting in strong deformations of these polyhedra. There are some other less-common motifs, though, such as 2 or 4 shorter bonds. It must be borne in mind that the strong disorder makes coordination assignment for $\mathrm{Bi}$ a rather arbitrary choice; this is especially seen in borates, and could be linked to the $\mathrm{Bi}_{2} \mathrm{O}_{3}-\mathrm{B}_{2} \mathrm{O}_{3}$ system being a good basis for glasses.

It must also be noted that some of the structures have unrealistically long reported $\mathrm{Bi}-\mathrm{O}$ bonds, such as $\mathrm{SrBi}_{2} \mathrm{~B}_{2} \mathrm{O}_{7}{ }^{661}$ and $\mathrm{Ba}_{3} \mathrm{BiP}_{3} \mathrm{O}_{12}$. ${ }^{662}$ The authors in this case suppose local disordered displacements that are not seen in the average structure, but are reflected as anomalously large thermal parameters. Such local displacements would be in line with current understanding of $\delta-\mathrm{Bi}_{2} \mathrm{O}_{3}$ and observed static disorder in pure and doped $\mathrm{Bi}_{2} \mathrm{Ru}_{2} \mathrm{O}_{7}{ }^{663}$

It is difficult to see any salient tendency of $\mathrm{Bi}$ coordination with compound composition, except possibly somewhat smaller coordination numbers at high $\mathrm{Bi}$ contents, as seen in silicate/germanate compounds and in line with tendencies postulated for glasses (see section 3.3 of main paper).

Concerning bonding of oxygen, compositions such as $(\mathrm{Ca}, \mathrm{Sr}) \mathrm{Bi}_{2} \mathrm{~B}_{2} \mathrm{O}_{7}{ }^{661}$ and $\mathrm{Bi}_{3} \mathrm{~B}_{5} \mathrm{O}_{12}{ }^{664}$ lie at the threshold where $\mathrm{O}^{2-}$ anions appear, that are not bonded to any glass-forming cation polyhedra.

\section{Comparison with lone-pair $\mathrm{Pb}^{2+}, \mathrm{Sn}^{2+}$, as well as modifiers without lone pairs}

In analogous compounds, $\mathrm{Pb}^{2+}$ (Table 30) and $\mathrm{Sn}^{2+}$ (Table 31) cations exhibit strong similitude with $\mathrm{Bi}^{3+}$, i.e. markedly asymmetric bonding brought about by the stereochemically active lone pair. There are some differences, though: the coordination shells tend to be less disordered, especially for the smaller, less polarisable $\mathrm{Sn}^{2+}$.

For $\mathrm{Pb}^{2+}$, there is a marked tendency for low-coordination bonding at high $\mathrm{Pb}$ contents, whereas such a trend is much less clear-cut for $\mathrm{Bi}^{3+}$. Distorted octahedra (6-Oct33) are seen in a compound where $\mathrm{Pb}$ content is relatively low $\left(\mathrm{Pb}_{6} \mathrm{~B}_{10} \mathrm{O}_{21}\right)$, also in line with what is postulated for glasses. At high $\mathrm{Pb}$ contents, the type of low-coordination bonding is also different: $\mathrm{Pb}^{2+}$ favours pyramids with itself at its apex, with a triangular (3-PyM) or square (4-PyM) base. In the latter case, the square is often rather " $3+1$ " in complex $\mathrm{PbO}$ compounds, with one bond significantly longer than the others, in contrast to the more symmetrical pure $\mathrm{PbO}$, both forms having regular (litharge) or "2+2" bonding (massicot). A "direct comparison" of $\mathrm{Bi}^{3+}$ and $\mathrm{Pb}^{2+}$ is possible for the compound $\mathrm{PbBiBO}_{4}$, which contains both ions and actually lies in the glass-forming range (see section 3.2 in main paper): $\mathrm{Pb}^{2+}$ adopts a clear threefold 3-PyM coordination (or 6-Oct33, but with 3 very long additional $\mathrm{Pb}-\mathrm{O}$ bonds), whereas the coordination around $\mathrm{Bi}^{3+}$ is clearly much more octahedral (6-Oct33), the difference between both groups of three bonds being much smaller for $\mathrm{Bi}^{3+}$.

It is difficult to establish tendencies for $\mathrm{Sn}^{2+}$, as the structures of only a few phosphate compounds were found, given the tendency in many systems for $\mathrm{Sn}^{2+}$ to disproportionate to $\mathrm{Sn}^{0}$ and $\mathrm{Sn}^{4+}$. Nevertheless, the observed behaviour of $\mathrm{Sn}^{2+}$ is logical with respect to $\mathrm{Pb}^{2+}$ : the tendency for threefold coordination as 3-PyM pyramids is very strong (except in pure $\mathrm{SnO}$, whose litharge form keeps the 4-PyM coordination), and the Sn-O distances are much less variable and slightly shorter than the $\mathrm{Pb}-\mathrm{O}$ ones. $\mathrm{Sn}^{2+}$ therefore appears to be the most "ordered" cation of the three, however retaining the asymmetry stemming from the stereochemically active lone pair, in line with the results of analyses on glasses ${ }^{219}$ and structural modelling. ${ }^{403}$ In fact, the latter modelling work predicts the lone pair character of $\mathrm{Sn}^{2+}$ to be more pronounced than that of $\mathrm{Pb}^{2+}$ and $\mathrm{Bi}^{3+}$. 
In comparison with the lone-pair cations, modifiers such as $\mathrm{Ca}^{2+}, \mathrm{Sr}^{2+}, \mathrm{Ba}^{2+}$ and $\mathrm{La}^{3+}$ (Table 32) expectedly tend to adopt more symmetrical, nondirectional geometries characteristic of ionic bonding, i.e. a larger coordination number, and no especially short bonds. In line with the compounds $\mathrm{ZnBi}_{2} \mathrm{~B}_{2} \mathrm{O}_{7}$ and $\mathrm{CaBiGaB}_{2} \mathrm{O}_{7}$ being relatively poor in $\mathrm{B}_{2} \mathrm{O}_{3}, \mathrm{Zn}^{2+}$ and $\mathrm{Ga}^{3+}$ adopt a tetrahedral oxygen environment, as they would do in corresponding glasses when they partly enter the network backbone.

\section{Coordination of glass-forming oxides}

The borates follow the usual trends seen in both glasses and crystalline compounds: 1) initial conversion of bridging $\mathrm{BO}_{3}$ triangles to bridging $\mathrm{BO}_{4}$ tetrahedra and attendant increase in connectivity, 2) progressive depolymerisation of the borate network by replacing bridging oxygen ions with terminal ones, 3 ) reversion to $\mathrm{BO}_{3}$ groups, with $2 \& 3$ occurring somewhat concomitantly. This may be seen in a list of example compounds.

- $\mathrm{BaB}_{4} \mathrm{O}_{11}$ : half $\mathrm{BO}_{3}$ and $\mathrm{BO}_{4}$ groups, 3D borate network (typical of phase 1)

- $\mathrm{BiB}_{3} \mathrm{O}_{6}$ : beyond phase 1 - layered borate network (mixed $\mathrm{BO}_{3}$ and $\mathrm{BO}_{4}$ ), with $\mathrm{Bi}^{3+}$ in between

- $\mathrm{CaBiGaB}_{2} \mathrm{O}_{7} \& \mathrm{ZnBi}_{2} \mathrm{~B}_{2} \mathrm{O}_{7}$ : layered mixed network of borate (resp. fully $\mathrm{BO}_{4} \&$ half $\left.\mathrm{BO}_{3} / \mathrm{BO}_{4}\right)$ and gallate/zincate tetrahedra, with $\mathrm{Ca}^{2+}$ and $\mathrm{Bi}^{3+}$ in between

- $(\mathrm{Ca}, \mathrm{Sr}) \mathrm{Bi}_{2} \mathrm{~B}_{2} \mathrm{O}_{7}: \mathrm{BO}_{3}$ triangles only interlinked via $\mathrm{Bi}^{3+}$, layered structure

- $\mathrm{PbBiBO}_{4}: \mathrm{BO}_{3}$ triangles, stronger bonding by $\mathrm{Pb}-\mathrm{O}$ and $\mathrm{Bi}-\mathrm{O}$ network.

In practice (see section 3.2 and Figure 9), glasses would have a glass former cation fraction roughly in the range from 3:4 (e.g. $\left.\mathrm{BiB}_{3} \mathrm{O}_{6}\right)$ down to ca. 1:3 (e.g. $\mathrm{PbBiBO}_{4}$ ), i.e. beyond phase 1 up to complete conversion into isolated $\mathrm{BO}_{3}$ groups. However, borate glasses behave somewhat differently from crystalline compounds, as shown in Figure 7, retaining considerable fractions of $\mathrm{BO}_{4}$ tetrahedra down to low $\mathrm{B}^{3+}$ contents, which implies additional Bi-O-B bonds.

In all these examined "glass-forming" compositions, $\mathrm{Ge}^{4+}$ and $\mathrm{P}^{5+}$ behaved the same as $\mathrm{Si}^{4+}$ (as did $\mathrm{Ga}^{3+}$ and $\mathrm{Zn}^{2+}$ ) forming $\mathrm{GeO}_{4}$ tetrahedra. Comparing the typical metal-oxygen bond lengths in these tetrahedra, we get $\mathrm{B}^{3+}: 148 ; \mathrm{P}^{5+}: 153 ; \mathrm{Si}^{4+}: 163 ; \mathrm{Ge}^{4+}: 174 ; \mathrm{Ga}^{3+}: 183, \mathrm{Zn}^{2+}$ : $194 \mathrm{pm}$. These distances agree well, within ca. $2 \mathrm{pm}$, with those calculated from the crystal radii. ${ }^{640}$ For $\mathrm{P}^{5+}$, the absence of irregular bonding stemming from double $\mathrm{P}=\mathrm{O}$ bonds was due to the compounds all being outside the ultraphosphate range. ${ }^{209,210}$ 
Th. Maeder - IMR 2012 - Review of $\mathrm{Bi}_{2} \mathrm{O}_{3}$-based glasses (supplements, 9.10.2012) - 99

Table 27. Oxygen around $\mathrm{Bi}$ in the $\alpha, \beta$ and $\delta$ phases of $\mathrm{Bi}_{2} \mathrm{O}_{3} \&$ derived phase.

\begin{tabular}{|c|c|c|}
\hline Compound & Coordination (see Figure 6) & Distances [pm] \\
\hline \multirow{2}{*}{$\alpha-\mathrm{Bi}_{2} \mathrm{O}_{3}$} & 5-Py14 (Bi1) & $\begin{array}{l}212 ; 220,221,253,263^{656} \\
213 ; 221,222,255,263^{645} \\
208 ; 217,221,254,263^{665}\end{array}$ \\
\hline & 6-Oct33 (Bi2) & $\begin{array}{l}213,220,228 ; 243,257,279^{\mathrm{a} 656} \\
213,220,228 ; 242,256,279^{645} \\
214,222,229 ; 248,254,280^{665}\end{array}$ \\
\hline$\beta-\mathrm{Bi}_{2} \mathrm{O}_{3}$ & $\begin{array}{l}4-\mathrm{BPy} \\
(5-\mathrm{Py} 14)\end{array}$ & $\begin{array}{l}209 ; 212,225,245,(273)^{648} \\
209 ; 212,225,247,(273)^{650}\end{array}$ \\
\hline$\delta-\mathrm{Bi}_{2} \mathrm{O}_{3}$ & (Various) & $\begin{array}{l}231(\times 3.98) ; 245(\times 2.02)^{\mathrm{b} 656} \\
231(\times 4.06) ; 245(\times 1.94)^{\mathrm{b} 648} \\
231(\times 2.56) ; 245(\times 3.44)^{\mathrm{b} 653} \\
231(\times 4.50) ; 310(\times 1.50)^{\mathrm{b} 645}\end{array}$ \\
\hline $\begin{array}{l}\mathrm{Bi}_{2-2 x} \mathrm{Sr}_{2 x} \mathrm{O}_{3-x}{ }^{\mathrm{c}} \\
(x=0.235)\end{array}$ & 4-Py13 & $201 ; 231(\times 3)^{649}$ \\
\hline $\begin{array}{ll}\text { a) } & \text { Calculated fr } \\
\text { b) } & \text { Measured at } \\
\text { assumed base }\end{array}$ & $\begin{array}{l}\text { data; not mentioned in the origina } \\
{ }^{\circ} \mathrm{C} \text {, within the stability limit of th } \\
\text { dom site occupation, without takin }\end{array}$ & $\begin{array}{l}\text { ymorph; average distances and coordination } \\
\text { rearrangements into account. }\end{array}$ \\
\hline Example of $r$ & common " $\beta$ " layered $\mathrm{Bi}_{2} \mathrm{O}_{3}$-based & onductor phase. \\
\hline
\end{tabular}

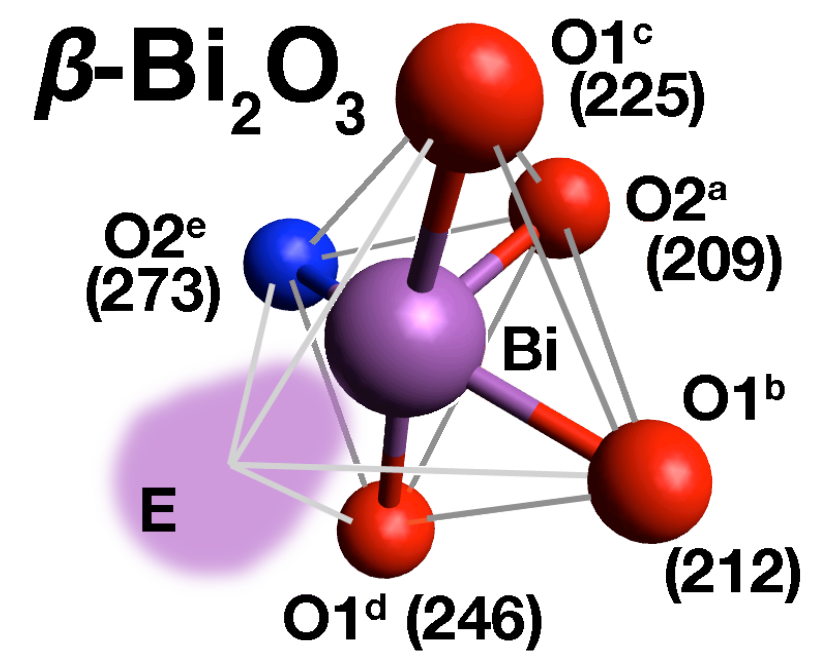

Figure 14. Oxygen coordination polyhedron around $\mathrm{Bi}$ in $\beta-\mathrm{Bi}_{2} \mathrm{O}_{3}$, with $\mathrm{O}$ numbered according to crystal lattice positions, and $\mathrm{Bi}-\mathrm{O}$ distances indicated in $\mathrm{pm}^{648,656}$ 
Table 28. Sillenites - $\mathrm{Bi}$ coordination and $\mathrm{Bi}-\mathrm{O}$ distances of $\mathrm{Bi}$ at normal "Bi" sites.

\begin{tabular}{lll}
\hline Compound $^{\mathrm{a}}$ & Coordination & Bi-O distances [pm] \\
\hline$\gamma-\mathrm{Bi}_{2} \mathrm{O}_{3}=\mathrm{Bi}_{12}\left(\mathrm{Bi}_{0.8} \square_{0.2}\right)\left(\mathrm{O}_{19.2} \mathrm{E}_{0.8}\right)^{\mathrm{b} 629}$ & $5-\mathrm{Py} 14^{\mathrm{f}}$ & $205 ; 240,228,246,256$ \\
\hline $\mathrm{Bi}_{12} \mathrm{SiO}_{20}{ }^{\mathrm{c} 658}$ & $5-\mathrm{Py} 14^{\mathrm{f}}$ & $206 ; 222,220,262,265$ \\
\hline $\mathrm{Bi}_{12} \mathrm{GeO}_{20}{ }^{\mathrm{c} 657,659}$ & $5-\mathrm{Py} 14^{\mathrm{f}}$ & $207 ; 221,222,262,262^{659}$ \\
\hline $\mathrm{Bi}_{12}\left(\mathrm{Fe}_{0.35} \mathrm{P}_{0.59} \square_{0.06}\right) \mathrm{O}_{20}{ }^{\mathrm{c} 659}$ & $5-\mathrm{Py} 14^{\mathrm{f}}$ & $208 ; 222,223,262,264^{657}$ \\
\hline $\mathrm{Bi}_{12}\left(\mathrm{Bi}_{0.50} \mathrm{Ga}_{0.50}\right)\left(\mathrm{O}_{19.50} \mathrm{E}_{0.50}\right)^{\mathrm{b} 659}$ & $5-\mathrm{Py} 14^{\mathrm{f}}$ & $207 ; 222,225,257,263$ \\
\hline $\mathrm{Bi}_{12}\left(\mathrm{Bi}_{0.50} \mathrm{Fe}_{0.50}\right)\left(\mathrm{O}_{19.50} \mathrm{E}_{0.50}\right)^{\mathrm{b} 659}$ & $5-\mathrm{Py} 14^{\mathrm{f}}$ & $207 ; 222,224,257,262$ \\
\hline $\mathrm{Bi}_{12}\left(\mathrm{Bi}_{0.67} \mathrm{Zn}_{0.33}\right)\left(\mathrm{O}_{19.33} \mathrm{E}_{0.67}\right)^{\mathrm{b} 659}$ & $5-\mathrm{Py} 14^{\mathrm{f}}$ & $207 ; 222,225,256,262$ \\
\hline $\mathrm{Bi}_{12}\left(\mathrm{Ti}_{0.90} \square_{0.10}\right)\left(\mathrm{O}_{19.80} \square_{0.20}\right)^{\mathrm{d} 659}$ & $5-\mathrm{Py} 14^{\mathrm{f}}$ & $207 ; 222,223,261,261$ \\
\hline $\mathrm{Bi}_{12}\left(\mathrm{Bi}_{0.25} \mathrm{~B}_{0.50} \square_{0.25}\right)\left(\mathrm{O}_{19.125} \mathrm{E}_{0.25} \square_{0.625}\right)^{\mathrm{d} 630}$ & $5-\mathrm{Py} 14^{\mathrm{f}}$ & $209 ; 217,221,263,272$ \\
\hline $\mathrm{Bi}_{12}\left(\mathrm{Bi}_{0.03} \mathrm{~V}_{0.89} \square_{0.08}\right) \mathrm{O}_{20}\left[\mathrm{O}_{0.27}\right]^{\mathrm{e} 659}$ & $6-\mathrm{Oct} 33$ & $209,219,222 ; 258,260$, \\
\end{tabular}

a) $\mathrm{E}=$ oxygen vacancy "filled" with $\mathrm{Bi}^{3+}$ lone pair; $\square=$ "unfilled" vacancy.

b) Stoichiometric according to Valant \& Suvorov, ${ }^{631}$ i.e. with oxygen sites filled by $\mathrm{O}^{2-}$ or replaced by $\mathrm{Bi}^{3+}$ lone pairs $\mathrm{E}$

c) Ideal sillenite, with average $\mathrm{M}$ valence $=4$

d) Nonstoichiometric - cation- \& oxygen-deficient

e) Nonstoichiometric - interstitial excess oxygen [O]

f) 5-Py14 coordination or 7-Py142 if two additional O anions at $\approx 300-310$ pm taken into account 


\section{Behaviour of Bi ${ }^{I I I}$ ruthenates and other compounds}

Lone-pair behaviour potentially has important implications for the properties of many technologically important oxides, such as the pyrochlore-structure ruthenates $\mathrm{Pb}_{2} \mathrm{Ru}_{2} \mathrm{O}_{6.5}$ and $\mathrm{Bi}_{2} \mathrm{Ru}_{2} \mathrm{O}_{7}$, and other compounds such as $\mathrm{Bi}_{3} \mathrm{Ru}_{3} \mathrm{O}_{11}$, the pyrochlores being used in TFRs as the conductive phase (section 4.6), and both bismuth ruthenates being useful as electrodes and catalysts. ${ }^{499,513,605}$ Diffraction studies (Table 35) indicate that the coordination around $\mathrm{Bi}^{3+}$ in $\mathrm{Bi}_{2} \mathrm{Ru}_{2} \mathrm{O}_{7}$ and $\mathrm{Bi}_{3} \mathrm{Ru}_{3} \mathrm{O}_{11}$ is apparently similar to that in analogous lanthanide compounds, nominally yielding the same symmetry and close bond lengths. However, in the case of $\mathrm{Bi}_{2} \mathrm{Ru}_{2} \mathrm{O}_{7}$, both pure and doped, detailed Rietveld refinement of neutron diffraction spectra ${ }^{663}$ reveals significant static displacive disorder of $\mathrm{Bi}^{3+}$ and linked oxygen, most likely stemming from the $\mathrm{Bi}^{3+}$ lone pair. This picture correlates well with the significant structural anomalies in bond lengths and angles seen in ruthenium pyrochlores of $\mathrm{Pb}^{\mathrm{II}}$ and $\mathrm{Bi}^{\mathrm{III}}$, compared to those of lanthanides ${ }^{666,667}$ (similar anomalies are seen for $\mathrm{Tl}^{\mathrm{III}}$, but involve different electronic phenomena ${ }^{403}$ ). These compounds lying close to the boundary between insulators and conductors, these anomalies, by slightly altering the electronic band structure, render $\mathrm{Pb}^{\mathrm{II}}$, $\mathrm{Bi}^{\mathrm{III}}$ and $\mathrm{Tl}^{\mathrm{III}}$, as well as mixed ${ }^{482,485}$ pyrochlores conducting, whereas lanthanide ruthenates $\left(\mathrm{Ln}_{2} \mathrm{Ru}_{2} \mathrm{O}_{7}\right)$ are semiconductors. ${ }^{482,}{ }^{666-668}$ In contrast to the pyrochlores, $\mathrm{Bi}_{3} \mathrm{Ru}_{3} \mathrm{O}_{11}$ and $\mathrm{La}_{3} \mathrm{Ru}_{3} \mathrm{O}_{11}$ differ more subtly in their electric properties, both being metallic. ${ }^{669}$ In these materials, which would deserve further structural studies similar to those performed on $\mathrm{Bi}_{2} \mathrm{Ru}_{2} \mathrm{O}_{7},{ }^{663}$ one of both $\mathrm{Bi}^{3+} / \mathrm{La}^{3+}$ sites $(9-\mathrm{Pr} 333)$ is more "suited" to asymmetric lone-pair ions.

Important properties of other compounds, such as catalyst activity of $\mathrm{Bi}_{2} \mathrm{Sn}_{2} \mathrm{O}_{7}{ }^{403}$ and biochemistry of Bi-based medicinal compounds, ${ }^{559}$ may also depend on lone-pair character, although electronegativity may also play a role. Therefore, the respective roles of electronegativity and lone-pair character in determining the structure and different properties (conductivity, catalytic activity, etc.) of materials should be better examined. The fact they are distinct is illustrated by a recent empirical attempt at correlating the lattice parameter of a large list of pyrochlore compounds with ionic radii corrected by electronegativity only. ${ }^{670}$ Whereas the calculated values are in general quite successful in predicting the lattice parameter, large errors are seen for many compounds containing lone-pair ions, such as $\mathrm{Bi}^{3+}$, $\mathrm{Pb}^{2+}$ and $\mathrm{Te}^{4+}$.

\section{Bond valence analysis}

Bond valence sums ${ }^{644}$ were calculated for selected coordination shells in compounds corresponding to glass-forming compositions (borates and one silicate), and are listed in Table 36. As this approach does not account for bond anisotropy, calculated bond valence sums - and especially individual bond valences - are expected to be imprecise for $\mathrm{Bi}^{3+}$ and $\mathrm{Pb}^{2+}$. For $\mathrm{BO}_{3}$ triangles and $\mathrm{BO}_{4}$ tetrahedra, this method provides an estimation of the allowed degree of variation in individual bond strengths.

Overall, the calculated valence sums agree relatively well with nominal values, with expectedly more summation errors for $\mathrm{Bi}^{3+}$. The strongest estimated individual $\mathrm{Bi}^{3+}-\mathrm{O}^{2-}$ bond valence ranges from 0.8 to 1.3 in the examined compounds, and the repartition of the individual bond valences is extremely variable, in line with the disordered valence shells typically found around $\mathrm{Bi}^{3+}$. Compared to $\mathrm{Bi}^{3+}$, the $\mathrm{Pb}^{2+}$ strongest-bond valence range (ca. 0.6-0.7) is shifted to lower values and exhibits less variability. Also, the contributions beyond the $3^{\text {rd }}$ (or $4^{\text {th }}$ ) bond are very small, which agrees well with the 3-PyM and 4-PyM coordination often found for $\mathrm{Pb}^{2+}$. For the much less polarisable $\mathrm{B}^{3+}$ the bond valences are close to their nominal values ( 1.00 for $\mathrm{Bi}^{3+}{ }_{\Delta}$ and 0.75 for $\mathrm{Bi}^{3+} \mathrm{T}$, in triangular and tetrahedral coordination respectively). Nevertheless, variations up to ca. \pm 0.05 are common, and \pm 0.10 is 
found in some compounds. This gives an idea of the bonding "flexibility" of borate coordination shells.

\section{Conclusions}

Having examined a wide range of compounds, including pure and doped $\mathrm{Bi}_{2} \mathrm{O}_{3}$, compounds related to glass-forming compositions and conducting ruthenates, it is clear that even in crystalline oxides, $\mathrm{Bi}^{3+}$ tends to adopt rather a very wide array of unusual, asymmetric and often ill-defined oxygen coordination shells, often comprising 3 (but also sometimes 2 or 4 ) short bonds, with a variable number of longer ones. This behaviour, which promotes lattice distortions or local disorder, is related to the stereochemically active lone-pair of $\mathrm{Bi}^{3+}$, a concept that has been revised recently to involve strong covalent bonding, with mixing not only of metal $s$ and $p$ electrons, but also $\mathrm{O} 2 p$ ones. This lone-pair character and covalent bonding of $\mathrm{Bi}^{3+}$, and their effects on crystal structures, are found to be very similar to that of $\mathrm{Pb}^{2+}$ and $\mathrm{Sn}^{2+}$, which suggests that the good glass-forming characteristics of $\mathrm{PbO}-, \mathrm{Bi}_{2} \mathrm{O}_{3}$ and SnO-based compositions are thereby related. There are some differences, though: of the three cations, $\mathrm{Bi}^{3+}$ tends to have the most disordered coordination shells, with varying numbers and geometries of both "short" and "long" bonds. $\mathrm{Pb}^{2+}$ is somewhat more ordered, and has a stronger tendency, at high concentrations, to adopt lower oxygen coordination numbers ( 3 or $3+1$, sometimes 4 ) in the form of metal-capped pyramids (3/4-PyM). $\mathrm{Sn}^{2+}$ behaves in a similar, but even more ordered way, with three almost equidistant bonds (3-PyM) favoured by the examined compounds.

Bond valence analysis (which must be regarded with caution in its isotropic formulation ${ }^{644}$ ) yields different valence distributions for $\mathrm{Bi}^{3+}$ and $\mathrm{Pb}^{2+}$, confirming that $\mathrm{Pb}^{2+}$ coordination shells tend to be better defined and that $\mathrm{Pb}^{2+}$ is compatible with small (3/4) coordination numbers. The strongest-bond valence for $\mathrm{Bi}^{3+}$ is not only (expectedly) higher than for $\mathrm{Pb}^{2+}$, but also more variable. These differences are expected to have important effects on glass structure, especially the borates due to the possible change in $\mathrm{B}^{3+}$ coordination shells.

It must be noted that other lone-pair cations are also relevant for glass formation, such as $\mathrm{Tl}^{+}$, $\mathrm{As}^{3+}, \mathrm{Sb}^{3+}, \mathrm{Se}^{4+}$ and $\mathrm{Te}^{4+}$, but only $\mathrm{TeO}_{2}$, and possibly some $\mathrm{Sb}_{2} \mathrm{O}_{3}$, are expected to be used in appreciable quantities in specialised glasses, due to toxicity concerns (see supplement 11). 
Table 29. Approximate coordination type around $\mathrm{Bi}^{3+}$ and $\mathrm{Bi}-\mathrm{O}$ distances, for different $\mathrm{Bi}^{\mathrm{III}}$-containing silicate, germanate, borate and phosphate compounds. Several entries per compound indicate distinct $\mathrm{Bi}$ locations.

\begin{tabular}{|c|c|c|}
\hline Compound \& ref. & $\begin{array}{l}\text { Coord- } \\
\text { ination }\end{array}$ & $\begin{array}{l}\text { Bi-O distances } \\
{[\mathrm{pm}]}\end{array}$ \\
\hline$\left(\mathrm{Bi}_{1.9} \mathrm{La}_{0.1}\right) \mathrm{SiO}_{5}{ }^{671}$ & $4-\mathrm{PyM} \dagger$ & $232(\times 4)$ \\
\hline $\mathrm{Bi}_{2} \mathrm{SiO}_{5}{ }^{671}$ & 4-PyM & $214,226,231,253$ \\
\hline $\mathrm{Bi}_{2} \mathrm{GeO}_{5}{ }^{672}$ & 4-PyM & $215,225,228,266$ \\
\hline $\mathrm{Bi}_{4} \mathrm{Si}_{3} \mathrm{O}_{12}{ }^{\text {a } 673}$ & 6-Oct33 & $213(\times 3) ; 262(\times 3)$ \\
\hline $\mathrm{Bi}_{4} \mathrm{Ge}_{3} \mathrm{O}_{12}{ }^{\mathrm{a}} 673$ & $6-O c t 33$ & $215(\times 3) ; 262(\times 3)$ \\
\hline $\mathrm{Bi}_{2} \mathrm{Ge}_{3} \mathrm{O}_{9}{ }^{674}$ & $6-O c t 33$ & $214(\times 3) ; 274(\times 3)$ \\
\hline \multirow{4}{*}{$\mathrm{Bi}_{4} \mathrm{~B}_{2} \mathrm{O}_{9}{ }^{660}$} & $6-O c t$ & $214,220,233,245,251,268$ \\
\hline & 7-Py142 & $233 ; 229,231,237,264 ; 252,268$ \\
\hline & 7-Py1222 & $219 ; 222,243 ; 236,250 ; 286,287$ \\
\hline & 7-PyM43 & $220,225,231,235 ; 266,278,287$ \\
\hline $\mathrm{BaBiBO}_{4}{ }^{351}$ & 5 -Py14 & $199 ; 223,228,253,264$ \\
\hline $\mathrm{PbBiBO}_{4}{ }^{675}$ & $6-O c t 222$ & 218,$220 ; 235,240 ; 250,259$ \\
\hline \multirow{2}{*}{$\mathrm{CaBi}_{2} \mathrm{~B}_{2} \mathrm{O}_{7}^{661}$} & 7-PyM43 & $214^{\mathrm{b}}, 221,223,263 ; 275,283,309$ \\
\hline & 7-PyM43 & $205^{\mathrm{b}}, 220,228,250 ; 278,297,311$ \\
\hline \multirow{2}{*}{$\mathrm{SrBi}_{2} \mathrm{~B}_{2} \mathrm{O}_{7}{ }^{661}$} & \multirow{2}{*}{$?^{\mathrm{c}}$} & $215^{\mathrm{b}}, 247,251,267,273,280,295,318$ \\
\hline & & $219^{b}, 253,259,264,264,271,283,308$ \\
\hline \multirow{2}{*}{$\mathrm{ZnBi}_{2} \mathrm{~B}_{2} \mathrm{O}_{7}{ }^{676}$} & $6-O c t 33$ & $217,222,232 ; 244,257,268$ \\
\hline & 6-Oct33 & $214,217,226 ; 252,269,279$ \\
\hline $\mathrm{CaBiGaB}_{2} \mathrm{O}_{7}{ }^{676}$ & $8-?^{\mathrm{d}}$ & $222,228,239,247,251,265,269,286$ \\
\hline \multirow{2}{*}{$\mathrm{BaBi}_{2} \mathrm{~B}_{4} \mathrm{O}_{10}{ }^{633}$} & 7-Py142 & $211 ; 217,234,240,263 ; 273,289$ \\
\hline & 7-Py142 & $214 ; 224,227,234,260 ; 290,313$ \\
\hline \multirow{2}{*}{$\mathrm{Bi}_{3} \mathrm{~B}_{5} \mathrm{O}_{12}{ }^{664}$} & $6-O c t 33$ & $209,220(\times 2) ; 271,275(\times 2)$ \\
\hline & 7-BPy43 & $211,224,226,233 ; 279,279,280$ \\
\hline $\mathrm{BiB}_{3} \mathrm{O}_{6}{ }^{677}$ & $6-$-Oct222 & $209(\times 2) ; 239(\times 2) ; 263(\times 2)$ \\
\hline \multirow{2}{*}{$\mathrm{Ba}_{3} \mathrm{BiP}_{3} \mathrm{O}_{12}{ }^{\text {a }} 662$} & $6-O c t 33$ & $238(\times 3) ; 278(\times 3)$ \\
\hline & $6-O c t 33$ & $260(\times 3) ; 281(\times 3)$ \\
\hline $\mathrm{Bi}_{2} \mathrm{P}_{4} \mathrm{O}_{13}{ }^{678}$ & $8-2222^{\mathrm{e}}$ & 218,$219 ; 231,236 ; 266,267 ; 276,280$ \\
\hline
\end{tabular}

a) Eulytite structures.

b) Nearest oxygen is a single $\mathrm{Bi}-\mathrm{O}-\mathrm{Bi}$ link in these structures ( $\mathrm{O}$ mostly bonded to both $\mathrm{Bi})$.

c) Probably only average structure according to authors - local distortions / displacements (especially of $\mathrm{Bi})$ strongly suspected from the neutron diffraction data.

d) $\mathrm{Bi}$ in ill-defined $\mathrm{BiO}_{8}$ coordination; structure $=\mathrm{Ga}_{2} \mathrm{~B}_{4} \mathrm{O}_{7}{ }^{5-}$ layers with $2 \mathrm{Ca}^{2+} \& 2 \mathrm{Bi}^{3+}$ in ordered interlayer positions.

e) Distorted irregular dodecahedron with strongly asymmetric bonding (closest $\mathrm{O}$ on one side). 
Table 30. Approximate coordination type around $\mathrm{Pb}^{2+}$ and $\mathrm{Pb}-\mathrm{O}$ distances, for some $\mathrm{Pb}^{\mathrm{II}}$-containing oxides. Several entries per compound indicate distinct $\mathrm{Pb}$ locations.

\begin{tabular}{|c|c|c|}
\hline Compound & $\begin{array}{l}\text { Coord- } \\
\text { ination }\end{array}$ & $\begin{array}{l}\text { Pb-O distances } \\
{[\mathrm{pm}]}\end{array}$ \\
\hline $\mathrm{PbO}$ (litharge) ${ }^{679}$ & 4-PyM & $230(4 \times)$ \\
\hline $\mathrm{PbO}(\text { massicot })^{680}$ & $4-\mathrm{BPy}^{\mathrm{a}}$ & $222,225,248(2 \times)$ \\
\hline \multirow{4}{*}{$\mathrm{Pb}_{2} \mathrm{SiO}_{4}{ }^{681}$} & 3-PyM & $218,218,227(298,298,328)$ \\
\hline & 4-PyM & $221,224,230,278(306,320,320)$ \\
\hline & 3-PyM & $234,234,247(290,290,324)$ \\
\hline & 3-PyM & $223,226,232(282,283,283)$ \\
\hline \multirow{4}{*}{$\begin{array}{l}\mathrm{Pb}_{2}\left(\mathrm{Si}_{1-x} \mathrm{Ge}_{x}\right) \mathrm{O}_{4}{ }^{681} \\
(x=0.24)\end{array}$} & 3-PyM & $213,230,230(296,308,325)$ \\
\hline & 4-PyM & $228,229,234,264(322,324,332)$ \\
\hline & 4-PyM & $219,222,237,272(290,330)$ \\
\hline & 4-РyM & $224,239,246,263(284,303)$ \\
\hline \multirow{3}{*}{$\mathrm{PbSiO}_{3}$ (alamosite) ${ }^{682}$} & 3-РyM & $228,229,260$ \\
\hline & 4-PyM & $223,225,247,247$ \\
\hline & 4-PyM & $230,231,247,258$ \\
\hline $\mathrm{PbBiBO}_{4}{ }^{675}$ & 3-PyM & $231,231,233(279,288,300)^{\mathrm{b}}$ \\
\hline \multirow{3}{*}{$\mathrm{Pb}_{6} \mathrm{~B}_{10} \mathrm{O}_{21}{ }^{683}$} & $6-O c t 33$ & $228,229,255 ; 276,285,294$ \\
\hline & 6-Oct33 & $223,239,244 ; 279,281,293$ \\
\hline & 4-PyM & $230,233,238,248(300,319,326)$ \\
\hline \multirow{2}{*}{$\mathrm{Pb}_{3} \mathrm{P}_{2} \mathrm{O}_{8}{ }^{\mathrm{c} 684}$} & $6-O c t$ & $261(2 \times), 262(2 \times), 275(2 \times)$ \\
\hline & 7-PyM34 & $233,245,250 ; 274,281,289,289$ \\
\hline
\end{tabular}

a) As often, intermediate form between 4-BPy and 4-PyM, but closer to former.

b) Can be seen as very distorted 6-Oct33, with the $\mathrm{Pb}^{2+}$ cation actually lying somewhat beyond the plane constituted of the 3 "far" $\mathrm{O}^{2-}$ anions, so can also be described as twice 3-PyM (near+far).

c) Low-temperature, low-symmetry form. 
Table 31. Approximate coordination type around $\mathrm{Sn}^{2+}$ and $\mathrm{Sn}-\mathrm{O}$ distances, for some $\mathrm{Sn}^{\mathrm{II}}$-containing oxides. Several entries per compound indicate distinct $\mathrm{Sn}$ locations.

\begin{tabular}{|c|c|c|}
\hline Compound & Coordination & Sn-O distances $[\mathrm{pm}]$ \\
\hline SnO (litharge-type) $)^{685}$ & 4-PyM & $222.4(4 \times)$ \\
\hline \multirow{3}{*}{$\mathrm{Sn}_{3} \mathrm{P}_{2} \mathrm{O}_{8}{ }^{686}$} & 3-PyM & $212,212,212(296,298)$ \\
\hline & 3-PyM & $208,210,212(305)$ \\
\hline & 3-PyM & $215,223,232(286,286)$ \\
\hline \multirow{4}{*}{$\beta-\mathrm{Sn}_{2} \mathrm{P}_{2} \mathrm{O}_{7}^{687}$} & 3-PyM & $211,219,223(286,286)$ \\
\hline & 3-PyM & $213,214,223$ \\
\hline & 3-PyM & $212,213,213$ \\
\hline & 3-РyM & $214,214,215$ \\
\hline
\end{tabular}

Table 32. Approximate coordination around other cations.

\begin{tabular}{|c|c|c|}
\hline Compound \& ref. & $\begin{array}{l}\text { Coord- } \\
\text { ination }\end{array}$ & $\begin{array}{l}\text { Cation-O distances } \\
{[\mathrm{pm}]}\end{array}$ \\
\hline $\mathrm{CaBi}_{2} \mathrm{~B}_{2} \mathrm{O}_{7}{ }^{661}$ & $\mathrm{CaO}_{8}$ & $232,232,240,245,247,256,275,287$ \\
\hline $\mathrm{CaBiGaB}_{2} \mathrm{O}_{7}{ }^{676}$ & $\mathrm{CaO}_{8}$ & $240(2 \times), 247,248,253(2 \times), 258(2 \times)$ \\
\hline $\mathrm{CaBi}_{2} \mathrm{~B}_{2} \mathrm{O}_{7}{ }^{676}$ & $\mathrm{CaO}_{6(+2)}{ }^{\dagger}$ & $232,232,240,245,247,256(275,286)$ \\
\hline $\mathrm{SrBi}_{2} \mathrm{~B}_{2} \mathrm{O}_{7}{ }^{661}$ & $\mathrm{SrO}_{6(+2)}^{\dagger}$ & $244,248,250,253,254,256,(261,289)$ \\
\hline $\mathrm{BaBiBO}_{4}{ }^{351}$ & $\mathrm{BaO}_{9}$ & $271,278,278,279,286,287,288,288,304$ \\
\hline $\mathrm{Ba}_{3} \mathrm{BiP}_{3} \mathrm{O}_{12}{ }^{662}$ & $\mathrm{BaO}_{9}$ & $267(3 \times), 270(3 \times), 301(3 \times)$ \\
\hline $\mathrm{BaBi}_{2} \mathrm{~B}_{4} \mathrm{O}_{10}{ }^{633}$ & $\mathrm{BaO}_{12}$ & $\begin{array}{l}275,275,275,275,285,286,288,291,309 \\
312,314,319\end{array}$ \\
\hline $\mathrm{BaB}_{4} \mathrm{O}_{7}^{688}$ & $\mathrm{BaO}_{9}$ & $261,267,269,269,276,287,298,300,308$ \\
\hline $\mathrm{BaB}_{4} \mathrm{O}_{7}^{688}$ & $\mathrm{BaO}_{10}$ & $\begin{array}{l}272,283,286,290,294,296,298,301,307 \\
312\end{array}$ \\
\hline $\mathrm{LaBO}_{3}{ }^{689}$ & $\mathrm{LaO}_{9}$ & $245,249(2 \times), 260(2 \times), 263(2 \times), 272(2 \times)$ \\
\hline $\mathrm{ZnBi}_{2} \mathrm{~B}_{2} \mathrm{O}_{7}^{676}$ & $\mathrm{ZnO}_{4}$ & $193,194,195,197$ \\
\hline $\mathrm{CaBiGaB}_{2} \mathrm{O}_{7}{ }^{676}$ & $\mathrm{GaO}_{4}$ & $183(4 \times)$ \\
\hline
\end{tabular}

$\uparrow$ Ca coordination relatively well ascertained, Sr more doubtful due to possible local atomic displacements see note $\mathrm{c}$ of Table 29. 
Table 33. Coordination around $\mathrm{B}^{3+}$ in examined oxides.

\begin{tabular}{|c|c|c|c|}
\hline Compound \& ref. & Cation $^{\dagger}$ & $\begin{array}{l}\text { (B,Si,Ge,P)-O distances } \\
{[\mathrm{pm}]}\end{array}$ & $\begin{array}{l}\text { Avg. } \\
{[\mathrm{pm}]}\end{array}$ \\
\hline $\mathrm{LaBO}_{3}{ }^{689}$ & $\mathrm{~B}^{3+}{ }_{\Delta}$ & $137,137,137$ & 137.3 \\
\hline \multirow{2}{*}{$\mathrm{Bi}_{4} \mathrm{~B}_{2} \mathrm{O}_{9}{ }^{660}$} & $\mathrm{~B}^{3+}{ }_{\Delta}$ & $137,137,139$ & \multirow{2}{*}{137.5} \\
\hline & $\mathrm{B}_{\Delta}^{3+}$ & $133,135,146$ & \\
\hline $\mathrm{PbBiBO}_{4}{ }^{675}$ & $\mathrm{~B}^{3+}{ }_{\Delta}$ & $136,137,142$ & 138.2 \\
\hline $\mathrm{BaBiBO}_{4}{ }^{351}$ & $\mathrm{~B}^{3+}{ }_{\Delta}$ & $137,138,139$ & 138.3 \\
\hline \multirow{2}{*}{$\mathrm{ZnBi}_{2} \mathrm{~B}_{2} \mathrm{O}_{7}{ }^{676}$} & $\mathrm{~B}_{\Delta}^{3+}$ & $133,134,140$ & 135.5 \\
\hline & $\mathrm{B}^{3+} \mathrm{T}$ & $146,148,151,153$ & 149.4 \\
\hline $\mathrm{CaBiGaB}_{2} \mathrm{O}_{7}{ }^{676}$ & $\mathrm{~B}^{3+}{ }_{\mathrm{T}}$ & $142,148,157(2 \times)$ & 151.0 \\
\hline \multirow{4}{*}{$\mathrm{BaBi}_{2} \mathrm{~B}_{4} \mathrm{O}_{10}{ }^{633}$} & $\mathrm{~B}^{3+}{ }_{\Delta}$ & $136,137,140$ & 137.5 \\
\hline & $\mathrm{B}^{3+} \mathrm{T}$ & $144,147,149,149$ & \multirow{3}{*}{148.1} \\
\hline & $\mathrm{B}^{3+} \mathrm{T}$ & $146,147,147,156$ & \\
\hline & $\mathrm{B}_{\mathrm{T}}^{3+}$ & $143,144,151,154$ & \\
\hline \multirow{4}{*}{$\mathrm{Bi}_{3} \mathrm{~B}_{5} \mathrm{O}_{12}{ }^{664}$} & $\mathrm{~B}^{3+}{ }_{\Delta}$ & $134,139,140$ & \multirow{2}{*}{137.3} \\
\hline & $\mathrm{B}^{3+}{ }_{\Delta}(2 \times)$ & $134,135,142$ & \\
\hline & $\mathrm{B}^{3+}{ }_{\mathrm{T}}$ & $144,148,148,149$ & \multirow{2}{*}{147.3} \\
\hline & $\mathrm{B}^{3+} \mathrm{T}$ & $139,148,150,151$ & \\
\hline \multirow{2}{*}{$\mathrm{BiB}_{3} \mathrm{O}_{6}{ }^{677}$} & $\mathrm{~B}^{3+}{ }_{\Delta}(2 \times)$ & $134,137,141$ & 137.3 \\
\hline & $\mathrm{B}^{3+}{ }_{\mathrm{T}}$ & $144(2 \times), 149(2 \times)$ & 146.5 \\
\hline \multirow{8}{*}{$\mathrm{BaB}_{4} \mathrm{O}_{7}{ }^{688}$} & $\mathrm{~B}_{\Delta}^{3+}$ & $137,138,140$ & \multirow{4}{*}{136.8} \\
\hline & $\mathrm{B}_{\Delta}^{3+}$ & $134,135,137$ & \\
\hline & $\mathrm{B}_{\Delta}^{3+}$ & $136,138,143$ & \\
\hline & $\mathrm{B}_{\Delta}^{3+}$ & $130,136,140$ & \\
\hline & $\mathrm{B}^{3+} \mathrm{T}$ & $146,149,151,152$ & \multirow{4}{*}{147.3} \\
\hline & $\mathrm{B}^{3+} \mathrm{T}$ & $141,145,151,151$ & \\
\hline & $\mathrm{B}_{\mathrm{T}}^{3+}$ & $141,144,148,153$ & \\
\hline & $\mathrm{B}^{3+} \mathrm{T}$ & $144,147,157,148$ & \\
\hline
\end{tabular}

\footnotetext{
${ }^{\dagger}$ Coordinations: $\Delta=\mathrm{B}$ in $\mathrm{BO}_{3}$ triangle; $\mathrm{T}=\mathrm{B}$ in $\mathrm{BO}_{4}$ tetrahedron.
} 
Table 34. Coordination around $\mathrm{Si}^{4+}, \mathrm{Ge}^{4+}$ and $\mathrm{P}^{5+}$ in examined oxides.

\begin{tabular}{|c|c|c|c|}
\hline Compound \& ref. & Cation $^{\dagger}$ & $\begin{array}{l}\text { (B,Si,Ge,P)-O distances } \\
{[\mathrm{pm}]}\end{array}$ & $\begin{array}{l}\text { Avg. } \\
{[\mathrm{pm}]}\end{array}$ \\
\hline$\left(\mathrm{Bi}_{1.9} \mathrm{La}_{0.1}\right) \mathrm{SiO}_{5}{ }^{671}$ & $\mathrm{Si}^{4+}{ }_{\mathrm{T}}$ & $159(2 \times), 166(2 \times)$ & 162.8 \\
\hline $\mathrm{Bi}_{2} \mathrm{SiO}_{5}{ }^{671}$ & $\mathrm{Si}^{4+}{ }_{\mathrm{T} 4}$ & $160,163(2 \times), 170$ & 164.0 \\
\hline $\mathrm{Pb}_{2} \mathrm{SiO}_{4}{ }^{681}$ & $\mathrm{Si}^{4+} \mathrm{T}$ & $159,164,170,171$ & 164.0 \\
\hline $\mathrm{Bi}_{4} \mathrm{Si}_{3} \mathrm{O}_{12}{ }^{\text {a } 673}$ & $\mathrm{Si}^{4+} \mathrm{T}$ & $162(4 \times)$ & 161.9 \\
\hline \multirow{3}{*}{$\mathrm{PbSiO}_{3}{ }^{682}$} & \multirow{3}{*}{$\mathrm{Si}^{4+} \mathrm{T}$} & $162,163,164,167$ & \multirow{3}{*}{162.9} \\
\hline & & $161,162,163,166$ & \\
\hline & & $160,161,162,163$ & \\
\hline \multirow{2}{*}{$\begin{array}{l}\mathrm{Pb}_{2}\left(\mathrm{Si}_{1-x} \mathrm{Ge}_{x}\right) \mathrm{O}_{4}{ }^{681} \\
(x=0.24)\end{array}$} & \multirow{2}{*}{$(\mathrm{Si}, \mathrm{Ge})^{4+} \mathrm{T}$} & $161,161,162,170$ & 163.5 \\
\hline & & $163,165,167,171$ & 164.5 \\
\hline $\mathrm{Bi}_{2} \mathrm{GeO}_{5}^{672}$ & $\mathrm{Ge}_{\mathrm{T}}^{4+}$ & $167(2 \times), 184(2 \times)$ & 175.7 \\
\hline $\mathrm{Bi}_{4} \mathrm{Ge}_{3} \mathrm{O}_{12}{ }^{\mathrm{a} 673}$ & $\mathrm{Ge}^{4+}{ }_{\mathrm{T}}$ & $174(4 \times)$ & 173.6 \\
\hline $\mathrm{Bi}_{2} \mathrm{Ge}_{3} \mathrm{O}_{9}{ }^{674}$ & $\mathrm{Ge}^{4+} \mathrm{T}$ & $171(2 \times), 175,177$ & 173.8 \\
\hline \multirow{2}{*}{$\mathrm{Ba}_{3} \mathrm{BiP}_{3} \mathrm{O}_{12}{ }^{662}$} & \multirow{2}{*}{$\mathrm{P}^{5+} \mathrm{T}$} & $151(4 \times)$ & \multirow{2}{*}{151.2} \\
\hline & & $152(4 \times)$ & \\
\hline \multirow{2}{*}{$\mathrm{Bi}_{2} \mathrm{P}_{4} \mathrm{O}_{13}{ }^{678}$} & \multirow{2}{*}{$\mathrm{P}^{5+} \mathrm{T}$} & $151,152,153,159$ & \multirow{2}{*}{154.0} \\
\hline & & $149,151,156,159$ & \\
\hline $\mathrm{Pb}_{3} \mathrm{P}_{2} \mathrm{O}_{8}{ }^{\mathrm{c} 684}$ & $\mathrm{P}_{\mathrm{T}}^{5+}$ & $148,154,154,156$ & 153.0 \\
\hline \multirow{4}{*}{$\mathrm{Sn}_{2} \mathrm{P}_{2} \mathrm{O}_{7}{ }^{687}$} & \multirow{4}{*}{$\mathrm{P}^{5+}{ }_{\mathrm{T}}$} & $150,151,152,159$ & \multirow{4}{*}{153.6} \\
\hline & & $151,151,152,160$ & \\
\hline & & $151,152,153,161$ & \\
\hline & & $151,151,152,161$ & \\
\hline
\end{tabular}

$\dagger$ Coordination: $\mathrm{T}=$ tetrahedral.

Table 35. Approximate coordination type and cation-oxygen distances, for $\mathrm{Bi}_{2} \mathrm{O}_{3}$ compounds with $\mathrm{RuO}_{2}$ and related compositions.

\begin{tabular}{llll}
\hline Compound \& ref. & Cation & $\begin{array}{l}\text { Coord- } \\
\text { ination }\end{array}$ & $\begin{array}{l}\text { Bi-O distances } \\
{[\mathrm{pm}]}\end{array}$ \\
\hline $\mathrm{Bi}_{3} \mathrm{Ru}_{3} \mathrm{O}_{11}{ }^{604,605}$ & $\mathrm{Bi}^{3+}$ & $8-\mathrm{C} 26 \mathrm{~s}$ & $\begin{array}{l}237(\times 2), 248(\times 6)^{605} \\
245(\times 2), 251(\times 6)^{604}\end{array}$ \\
\hline & & $9-\mathrm{Pr} 333$ & $\begin{array}{l}224(\times 3) ; 262(\times 3) ; 277(\times 3)^{605} \\
221(\times 3) ; 260(\times 3) ; 282(\times 3)^{604}\end{array}$ \\
\hline $\mathrm{La}_{3} \mathrm{Ru}_{3} \mathrm{O}_{11}{ }^{606}$ & $\mathrm{La}^{3+}$ & $8-\mathrm{C} 26 \mathrm{~s}$ & $237(\times 2), 256(\times 6)$ \\
\hline $\mathrm{Bi}_{2} \mathrm{Ru}_{2} \mathrm{O}_{6.9}{ }^{605}$ & $9-\mathrm{Pr} 333$ & $234(\times 3) ; 268(\times 3) ; 286(\times 3)$ \\
$\mathrm{Bi}_{1.9} \mathrm{Ru}_{2} \mathrm{O}_{6.9}{ }^{663}$ & $\mathrm{Bi}^{3+}$ & $8-\mathrm{C} 26 \mathrm{~s}$ & $223(\times 2), 258(\times 6)$ \\
\hline $\mathrm{Pr}_{2} \mathrm{Ru}_{2} \mathrm{O}_{7}{ }^{666}$ & $\mathrm{Pr}^{3+}$ & $8-\mathrm{C} 26 \mathrm{~s}$ & $223(\times 2), 255(\times 6)$ \\
\hline
\end{tabular}


Table 36. Bond-valence analysis ${ }^{644}$ of selected coordination shells.

\begin{tabular}{|c|c|c|c|}
\hline Compound \& ref. & Cation $^{\dagger}$ & $\begin{array}{c}\text { Valence } \\
\text { sum }\end{array}$ & Bond valences \\
\hline \multirow{3}{*}{$\mathrm{PbBiBO}_{4}{ }^{675}$} & $\mathrm{Bi}^{3+}$ & 3.04 & $0.79,0.75,0.49,0.42,0.33,0.26$ \\
\hline & $\mathrm{Pb}^{2+}$ & 2.11 & $0.59,0.58,0.56,0.16,0.13,0.09$ \\
\hline & $\mathrm{B}_{\Delta}^{3+}$ & 2.92 & $1.04,0.99,0.89$ \\
\hline \multirow{2}{*}{$\mathrm{BaBiO}_{4}{ }^{351}$} & $\mathrm{Bi}^{3+}$ & 3.13 & $1.31,0.69,0.60,0.31,0.22$ \\
\hline & $\mathrm{B}_{\Delta}^{3+}$ & 2.90 & $0.99,097,0.94$ \\
\hline \multirow{4}{*}{$\mathrm{CaBi}_{2} \mathrm{~B}_{2} \mathrm{O}_{7}{ }^{661}$} & $\mathrm{Bi}^{3+}$ & 2.88 & $0.87,0.72,0.68,0.23,0.17,0.14,0.07$ \\
\hline & $\mathrm{Bi}^{3+}$ & 3.10 & $1.11,0.74,0.60,0.33,0.15,0.09,0.06$ \\
\hline & $\mathrm{B}^{3+}{ }_{\Delta}$ & 3.06 & $1.04,1.03,0.98$ \\
\hline & $\mathrm{B}^{3+}{ }_{\Delta}$ & 2.99 & $1.01,0.99,0.99$ \\
\hline \multirow{4}{*}{$\mathrm{ZnBi}_{2} \mathrm{~B}_{2} \mathrm{O}_{7}{ }^{676}$} & $\mathrm{Bi}^{3+}$ & 2.93 & $0.81,0.71,0.54,0.39,0.27,0.20$ \\
\hline & $\mathrm{Bi}^{3+}$ & 2.99 & $0.88,0.82,0.63,0.31,0.20,0.15$ \\
\hline & $\mathrm{B}_{\Delta}^{3+}$ & 3.06 & $1.04,1.03,0.98$ \\
\hline & $\mathrm{B}^{3+} \mathrm{T}$ & 2.99 & $1.01,0.99,0.99$ \\
\hline \multirow{6}{*}{$\mathrm{BaBi}_{2} \mathrm{~B}_{4} \mathrm{O}_{10}{ }^{633}$} & $\mathrm{Bi}^{3+}$ & 3.21 & $0.94,0.80,0.51,0.43,0.23,0.18,0.12$ \\
\hline & $\mathrm{Bi}^{3+}$ & 3.05 & $0.88,0.67,0.61,0.46,0.26,0.11,0.06$ \\
\hline & $\mathrm{B}_{\Delta}^{3+}$ & 2.97 & $1.04,0.99,0.93$ \\
\hline & $\mathrm{B}^{3+} \mathrm{T}$ & 3.04 & $0.83,0.77,0.73,0.72$ \\
\hline & $\mathrm{B}^{3+} \mathrm{T}$ & 2.93 & $0.79,0.77,0.76,0.60$ \\
\hline & $\mathrm{B}^{3+} \mathrm{T}$ & 2.98 & $0.85,0.81,0.69,0.63$ \\
\hline \multirow{3}{*}{$\mathrm{BiB}_{3} \mathrm{O}_{6}{ }^{677}$} & $\mathrm{Bi}^{3+}$ & 3.37 & $1.01,1.01,0.45,0.45,0.23,0.23$ \\
\hline & $\mathrm{B}^{3+}{ }_{\Delta}$ & 2.99 & $1.09,1.00,0.90$ \\
\hline & $\mathrm{B}^{3+} \mathrm{T}$ & 3.11 & $0.83,0.83,0.72,0.72$ \\
\hline \multirow{2}{*}{$\mathrm{Bi}_{4} \mathrm{Si}_{3} \mathrm{O}_{12}{ }^{673}$} & $\mathrm{Bi}^{3+}$ & 3.43 & $0.91,0.91,0.91,0.23,0.23,0.23$ \\
\hline & $\mathrm{Si}^{4+}$ & 4.05 & $1.01,1.01,1.01,1.01$ \\
\hline \multirow{3}{*}{$\mathrm{Pb}_{6} \mathrm{~B}_{10} \mathrm{O}_{21}{ }^{683}$} & $\mathrm{~Pb}^{2+}$ & 1.98 & $0.64,0.62,0.31,0.17,0.14,0.11$ \\
\hline & $\mathrm{Pb}^{2+}$ & 2.03 & $0.73,0.47,0.41,0.16,0.15,0.11$ \\
\hline & $\mathrm{Pb}^{2+}$ & 2.01 & $0.60,0.55,0.48,0.37$ \\
\hline
\end{tabular}

$\uparrow$ Boron coordinations: $\Delta=\mathrm{BO}_{3}$ triangle; $\mathrm{T}=\mathrm{BO}_{4}$ tetrahedron. 


\section{Estimation of cooling rates}

During cooling between the melting point of the glass (i.e. the liquidus temperature in the equilibrium phase diagram) and the glass transition temperature $T_{g}$, vitrification is in kinetic competition with the processes of nucleation of crystallites and - if nucleation has occurred crystallite growth. Therefore, the glass forming ability of "borderline" systems strongly depends on the cooling rate through critical temperature range where nucleation and growth may occur. The true cooling rate inside the glass is difficult to estimate accurately, so the indicated values should be treated with caution. In this work, the indicated cooling rate is that estimated by the authors if given in their work. "Air quenched" glasses were assumed to cool at $\approx 1 \mathrm{~K} \cdot \mathrm{s}^{-1}$. Otherwise, if the glasses were cast or pressed, the cooling rate was estimated according to the procedure defined hereafter, with the following reasonable assumptions:

- Cold wall temperatures remain essentially constant, which is reasonable for sufficiently massive moulds / plates, given that materials such as stainless steel $\left(\approx 15 \ldots 25 \mathrm{~W} \cdot \mathrm{m}^{-1} \cdot \mathrm{K}^{-1}\right), \quad$ aluminium $\quad\left(6061 \quad\right.$ alloy, $\left.\approx 170 \mathrm{~W} \cdot \mathrm{m}^{-1} \cdot \mathrm{K}^{-1}\right), \quad$ brass $\left(\approx 90 \mathrm{~W} \cdot \mathrm{m}^{-1} \cdot \mathrm{K}^{-1}\right)$ and bulk graphite $\left(\approx 100 \mathrm{~W} \cdot \mathrm{m}^{-1} \cdot \mathrm{K}^{-1}\right)$ all have a much higher thermal conductivity than that of the glass.

- Glass thermal diffusivity was assumed to be constant, at $0.4 \mathrm{~mm}^{2} \cdot \mathrm{s}^{-1}$ (reasonable for a "heavy" glass at high temperature).

- The initial temperatures of the glass melt and mould/ wall were assumed to be $1000^{\circ} \mathrm{C}$ and $200^{\circ} \mathrm{C}$ respectively, and cooling rate is specified for $600^{\circ} \mathrm{C}$, i.e. the middle of this range. This corresponds well to relatively low-melting glasses.

- If the glass thickness was not mentioned, it was assumed to be $5 \mathrm{~mm}$ for "pouring into a mould", $3 \mathrm{~mm}$ for "pouring onto a plate", $2 \mathrm{~mm}$ for "pouring and pressing", $0.5 \mathrm{~mm}$ for roller quenching and $0.2 \mathrm{~mm}$ for twin roller quenching. Fritting (i.e. pouring into water) was considered for simplicity as "pouring and pressing" with a thickness of $2 \mathrm{~mm}$.

Fast cooling a glass from the melt is typically done, in ascending cooling rate, by various methods:

- Pouring into a mould

- Pouring onto a plate

- Pouring onto a plate with immediate pressing with a plate from the top

- Pouring into water, i.e. fritting

- Roller quenching

- Twin roller quenching

Cooling in the glass will occur through a thickness $L$ (single-side cooling). For double-side cooling (casting-pressing or roller quenching), $L$ is half the glass film thickness (Figure 15). In this case, the time-dependent temperature is the well-known Fourier series: ${ }^{690}$

$$
\frac{\Delta T(x, t)}{\Delta T_{0}}=\frac{2}{\pi} \cdot \sum_{n=1}^{\infty}\left[\frac{1-(-1)^{n}}{n} \cdot \sin \left(\frac{n \cdot \pi \cdot x}{2 L}\right) \cdot \exp \left(-\frac{D \cdot n^{2} \cdot \pi^{2} \cdot t}{4 L^{2}}\right)\right]
$$

Here, $\Delta T(x, t) / \Delta T_{0}$ is the fractional remaining temperature difference between melting and cold-wall temperature at a distance $x$ from the wall and time $t$ from casting, and $D$ is the 
thermal diffusivity in the glass. Here, we are chiefly interested in the slowest-cooling part of the glass, i.e. $x=L$. Also, we can safely assume that the higher-order members of the series decay rapidly and become negligible. Therefore, we arrive at a much simpler expression:

$$
\frac{\Delta T(L, t)}{\Delta T_{0}} \cong \frac{4}{\pi} \cdot \exp \left(-\frac{t}{t_{c}}\right) \text {, where } t_{c}=\frac{4 L^{2}}{\pi^{2} \cdot D} \text { is the fundamental decay period. }
$$

Here, we want to calculate the cooling rate $-d T / d t$ for $\Delta T / T_{0} \approx 0.5$, therefore:

$$
\begin{aligned}
& t_{1 / 2} \cong t_{c} \cdot \ln \frac{8}{\pi}, \text { which yields, with our assumptions: } \\
& -\frac{d T}{d t}\left(L, t_{1 / 2}\right) \cong \frac{\Delta T_{0}}{2 t_{c}} \cong \frac{400 \mathrm{~mm}^{2} \cdot \mathrm{K} \cdot \mathrm{s}^{-1}}{L^{2}}
\end{aligned}
$$

In this work, the cooling rates are for convenience expressed as a "quenching index", $Q$ :

$$
Q=\log _{10}\left[-\frac{d T}{d t}\left(L, t_{1 / 2}\right)\right] \text {, where the cooling rate is expressed in } \mathrm{K} \mathrm{s}^{-1} \text {. }
$$

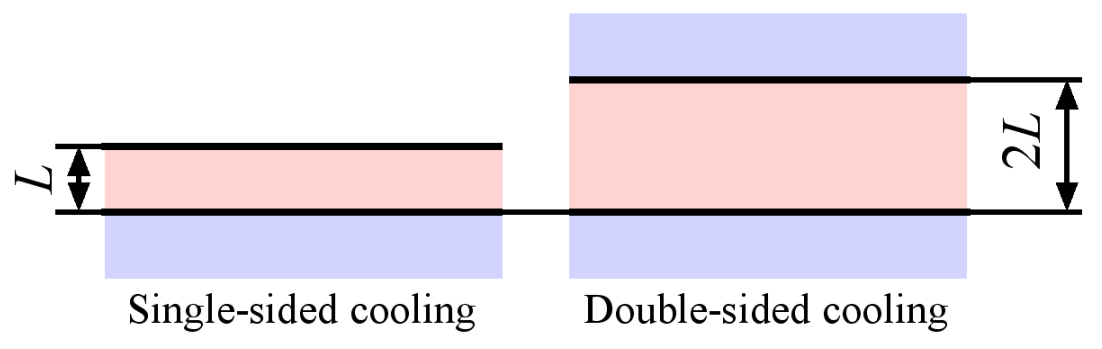

Figure 15. Thickness $L$ for single- or double-sided cooling of glass. 


\section{Additional references for supplements}

535. G. Agricola: 'De Re Metallica [1556, translation into English]'; 1912, London (UK), The Mining Magazine.

536. A. Neri, C. Merret, J. Kunckel, J. F. Henckel, J. C. Orschall, and M. Zimmermann: 'L'art de la verrerie [The art of glassmaking]'; 1752, Durand / Pissot, Paris (FR).

537. Anon: 'Sur le bismuth [On bismuth]', Histoire de l'Académie Royale des Sciences - année 1753 ; compte rendu des travaux de Geoffroy, C.F. \& comparaison avec ceux de Pott, J.H. [account of the work of Geoffroy, C.F.\& comparison with that of Pott, J.H.], 1757, 190-194.

538. M. Faraday: 'The Bakerian lecture: On the manufacture of glass for optical purposes', Philosophical Transactions of the Royal Society of London, 1830, 120, 1-57.

539. L. Tanquerel des Planches: 'Traité des maladies de plomb ou saturnines [Treatise on lead diseases]'; 1839, Paris (FR), Ferra.

540. M. Lessler: 'Lead and lead poisoning from antiquity to modern times', The Ohio Journal of Science, 1988, 88(3), 133-146.

541. M. S. Tite, I. Freestone, R. Mason, J. Molera, M. Vendrell-Saz, and N. Wood: 'Lead glazes in antiquity - methods of production and reasons for use', Archaeometry, 1998, 40(2), 241-260.

542. M. Tite, I. Freestone, R. Mason, J. Molera, S. Vendrell, M, and N. Wood: 'The beginnings of vitreous materials in the Near East and Egypt', Accounts of Chemical Research, 2002, 35(8), 585-593.

543. A. Shortland: 'The use and origin of antimonate colorants in early Egyptian glass', Archaeometry, 2002, 44(4), 517-530.

544. I. Borgia, B. Brunetti, A. Giulivi, A. Sgamellotti, F. Shokouhi, P. Oliaiy, J. Rahighi, M. Lamehi Rachti, M. Mellini, and C. Viti: 'Characterisation of decorations on Iranian $\left(10^{\text {th }}-13^{\text {th }}\right.$ century) lustreware', Appl. Phys. A, 2004, 79(2), 257-261.

545. H. Needleman: 'Lead poisoning', Annual Review of Medicine, 2004, 55, 209-222.

546. L. Thomas: 'Lead and you', The Gamma Series of the Royal Society of New Zealand, 2004, 14.

547. F. Gan, H. Cheng, and Q. Li: 'Origin of Chinese ancient glasses - study on the earliest Chinese ancient glasses', Science in China Series E: Technological Sciences, 2006, 49(6), 701-713.

548. E. O. von Lippmann: 'Die Geschichte des Wismuts zwischen 1400 und 1800: ein Beitrag zur Geschichte der Technologie und der Kultur [The history of bismuth between 1400 and 1800: a contribution to the history of technology and culture]'; 1930, Berlin (DE), Springer.

549. G. Agricola: 'Bermannus, sive de Re Metallica'; 1530, Basel $(\mathrm{CH})$, Froben.

550. J. Amman and H. Sachs: 'Der Schrifftgießer [The type founder]', in 'Eygentliche Beschreibung aller Stände auff Erden, hoher und nidriger, geistlicher und weltlicher, aller Künsten, Handwercken und Händeln, und vom größten bis zum kleinesten, auch von irem Ursprung / Erfindung und Gebreuchen [Proper description of all estates on Earth, high and lowly, spiritual and earthly, all arts, trades and commerces, and from the greatest to the smallest, and also of their origin / invention and customs]', 20; 1568, Frankfurt-am-Main (DE), Feyerabend.

551. G. Padeletti and P. Fermo: 'Bismuth knowledge during the Renaissance strengthened by its use in Italian lustres production', Appl. Phys. A, 2004, 79(2), 277-281.

552. O. V. Mazurin, M. V. Strel'tsina, T. P. Shvaiko-Shvaikovska, and A. O. Mazurina: 'Features of investigation into the properties of glasses and melts from the late $19^{\text {th }}$ century to the present day', Glass Physics and Chemistry, 2002, 28(5), 271-280.

553. O. V. Mazurin: 'The history and tendencies of investigations into the properties of glasses from the early $20^{\text {th }}$ century to the present day revisited', Glass Physics and Chemistry, 2006, 32(2), 141-145. 
554. J. O. Nriagu: 'The rise and fall of leaded gasoline', The Science of the Total Environment, 1990, 92.

555. R. Faulk and J. Gray: 'Getting the lead out? The misuse of public nuisance litigation by public authorities and private counsel', Gardere, Dallas (USA), 2006.

556. C. J. Williams, S. Flaherty, and J. J. Robinson, State of Rhode Island vs. Lead Industries Association. 2008, Rhode Island Supreme Court (USA).

557. ATSDR, Toxicological profile for lead. 2007, USA Agency for Toxic Substances and Disease Registry: Atlanta (USA).

558. J. R. Lambert: 'Pharmacology of bismuth-containing compounds', Reviews of Infectious Diseases, 1991, 13(S8), S691-S695.

559. H. Sun, H. Li, and P. J. Sadler: 'The biological and medicinal chemistry of bismuth', Chemische Berichte, 1997, 130(6), 669-691.

560. P. Marcillac, N. Coron, G. Dambier, J. Leblanc, and J.-P. Moalic: 'Experimental detection of alpha-particles from the radioactive decay of natural bismuth', Nature, 2003, 422, 876-878.

561. ATSDR, Toxicological profile for strontium. 2004, USA Agency for Toxic Substances and Disease Registry: Atlanta (USA).

562. ATSDR, Toxicological profile for barium and barium compounds. 2007, USA Agency for Toxic Substances and Disease Registry: Atlanta (USA).

563. ATSDR, Draft toxicological profile for cadmium. 2008, USA Agency for Toxic Substances and Disease Registry: Atlanta (USA).

564. ATSDR, Draft toxicological profile for boron. 2007, USA Agency for Toxic Substances and Disease Registry: Atlanta (USA).

565. ATSDR, Draft toxicological profile for vanadium. 2009, USA Agency for Toxic Substances and Disease Registry: Atlanta (USA).

566. ATSDR, Toxicological profile for arsenic. 2007, USA Agency for Toxic Substances and Disease Registry: Atlanta (USA).

567. ATSDR, Toxicological profile for antimony and compounds. 1992, USA Agency for Toxic Substances and Disease Registry: Atlanta (USA).

568. ATSDR, Toxicological profile for tungsten. 2005, USA Agency for Toxic Substances and Disease Registry: Atlanta (USA).

569. ATSDR, Toxicological profile for selenium. 2003, USA Agency for Toxic Substances and Disease Registry: Atlanta (USA).

570. WHO, Guidelines for drinking-water quality, $2^{\text {nd }}$ edition - Vol. 1 - Recommmendations - 3. Chemical aspects. 1993, World Health Organisation: Geneva (CH).

571. Sigma-Aldrich (CH), http://www.sigmaaldrich.com/switzerland-suisse.html, accessed 201011.

572. J. Domingo: 'Vanadium: A review of the reproductive and developmental toxicity', Reproductive Toxicology, 1996, 10(3), 175-182.

573. P. Trumbo, A. A. Yates, S. Schlicker, and M. Poos: 'Dietary reference intakes: vitamin A, vitamin $\mathrm{K}$, arsenic, boron, chromium, copper, iodine, iron, manganese, molybdenum, nickel, silicon, vanadium, and zinc', Journal of the American Dietetic Association, 2001, 101(3), 294301.

574. D. Rehder: 'Biological and medicinal aspects of vanadium', Inorganic Chemistry Communications, 2003, 6(5), 604-617.

575. A. Léonard and G. Gerber: 'Mutagenicity, carcinogenicity and teratogenicity of antimony compounds', Mutation Research, 1996, 366, 1-8.

576. B. Elliott, J. Mackay, P. Clay, and J. Ashby: 'An assessment of the genetic toxicology of antimony trioxide', Mutation Research, 1998, 415, 109-117. 
577. R. Poon, I. Chu, P. Lecavalier, V. Vallib, W. Foster, S. Gupta, and B. Thomas: 'Effects of antimony on rats following 90-day exposure via drinking water', Food and Chemical Toxicology, 1998, 36(1), 21-35.

578. P. Hext, P. Pinto, and B. Rimmel: 'Subchronic feeding study of antimony trioxide in rats', Journal of Applied Toxicology, 1999, 19, 205-209.

579. E. R. T. Tiekink: 'Antimony and bismuth compounds in oncology', Critical Reviews in Oncology/Hematology, 2002, 42(3), 217-224.

580. Y. Sano, H. Satoh, M. Chiba, M. Okamoto, K. Serizawa, H. Nakashima, and K. Omae: 'Oral toxicity of bismuth in rat: single and 28-day repeated administration studies', Journal of Occupational Health, 2005, 47(4), 293-298.

581. Y. Sano, H. Satoh, M. Chiba, A. Shinohara, M. Okamoto, K. Serizawa, H. Nakashima, and K. Omae: 'A 13-week toxicity study of bismuth in rats by intratracheal intermittent administration', Journal of Occupational Health, 2005, 47(3), 242-248.

582. G. G. Briand and N. Burford: 'Bismuth compounds and preparations with biological or medicinal relevance', Chemical Reviews, 1999, 99, 2601-2657.

583. H. Breunig: 'Bismuth compounds', Kirk-Othmer Encyclopedia of Chemical Technology, 2002, 4, 16-43.

584. C. M. J. M. Pypen, K. Dessein, J. A. Helsen, M. Gomes, H. Leenders, and J. D. de Bruijn: 'Comparison of the cytotoxicity of molybdenum as powder and as alloying element in a niobium-molybdenum alloy', Journal of Materials Science: Materials in Medicine, 1998, 9, 761-765.

585. H. Matsuno, A. Yokoyama, F. Watari, M. Uo, and T. Kawasaki: 'Biocompatibility and osteogenesis of refractory metal implants, titanium, hafnium, niobium, tantalum and rhenium', Biomaterials, 2001, 22, 1253-1262.

586. S. Nielsen: 'The biological role of strontium', Bone, 2004, 35, 583-588.

587. M. C. Yarema and S. C. Curry: 'Acute tellurium toxicity from ingestion of metal-oxidizing solutions', Pediatrics, 2005, 116(2), e319-e321.

588. J. Ren, L. Yang, J. Qiu, D. Chen, X. Jiang, and C. Zhu: 'Effect of various alkaline-earth metal oxides on the broadband infrared luminescence from bismuth-doped silicate glasses', Solid State Communications, 2006, 140(1), 38-41.

589. J. Ren, J. Qiu, D. Chen, X. Hu, X. Jiang, and C. Zhu: 'Ultrabroad infrared luminescence from Bi-doped aluminogermanate glasses', Solid State Communications, 2007, 353, 1508-1514.

590. M. Peng, D. Chen, J. Qiu, X. Jiang, and C. Zhu: 'Bismuth-doped zinc aluminosilicate glasses and glass-ceramics with ultra-broadband infrared luminescence', Optical Materials, 2007, 29, 556-561.

591. B. I. Denker, B. I. Galagan, V. V. Osiko, L. L. Shluman, S. E. Sverchkov, and E. M. Dianov: 'Factors affecting the formation of near infrared-emitting optical centers in Bi-doped glasses', Appl. Phys. B, 2010, 98(2-3), 455-458.

592. Y. Shimizugawa, N. Sugimoto, and K. Hirao: 'X-ray absorption fine structure glasses containing $\mathrm{Bi}_{2} \mathrm{O}_{3}$ with third-order non-linearities', Journal of Non-Crystalline Solids, 1997, 221(2-3), 208-212.

593. Y. Fujimoto and M. Nakatsuka: 'Infrared luminescence from bismuth-doped silica glass', Japanese Journal of Applied Physics, 2001, 40(3B), L279-L281.

594. X. J. Wang and H. P. Xia: 'Infrared superbroadband emission of Bi ion doped germaniumaluminum-sodium glass', Optics Communications, 2006, 268(1), 75-78.

595. T. Ohkura, Y. Fujimoto, M. Nakatsuka, and S. Young-Seok: 'Local structures of bismuth ion in bismuth-doped silica glasses analyzed using $\mathrm{Bi}_{\mathrm{III}} \mathrm{X}$-ray absorption fine structure', J. Am. Ceram. Soc., 2007, 90(11), 3596-3600. 
596. R. Scholder and H. Stobbe: 'Über Bismutate [On bismuthates]', Zeitschrift für Anorganische und Allgemeine Chemie, 1941, 247(4), 392-414.

597. G. Gattow and W. Klippel: 'Untersuchungen über Bismut(V)-oxid [Studies on bismuth(V) oxide]', Zeitschrift für Anorganische und Allgemeine Chemie, 1980, 470(1), 25-34.

598. B. Begemann and $\mathrm{M}$. Jansen: ${ }^{\prime} \mathrm{Bi}_{4} \mathrm{O}_{7}$, das erste definierte binäre Bismut(III,V)-Oxid $\left[\mathrm{Bi}_{4} \mathrm{O}_{7}\right.$, the first well-defined binary bismuth(III,V) oxide]', Journal of the Less-Common Metals, 1989, 156(1-2), 123-135.

599. A. S. Prakash, C. Shivakumara, M. S. Hegde, L. Dupont, and J. M. Tarascon: 'Synthesis of non-stoichiometric $\mathrm{Bi}_{2} \mathrm{O}_{4-x}$ by oxidative precipitation', Materials Research Bulletin, 2007, 42(4), 707-712.

600. A. N. Romanov, Z. T. Fattakhova, Y. N. Rufov, and D. P. Shashkin: 'Kinetics of the thermal desorption of atomic oxygen during transformations $\mathrm{BiO}_{2-x} \rightarrow \beta-\mathrm{Bi}_{2} \mathrm{O}_{3} \rightarrow \alpha-\mathrm{Bi}_{2} \mathrm{O}_{3}{ }^{\prime}$, Kinetics and Catalysis, 2001, 42(2), 306-311.

601. M. Cao, C. Hu, G. Peng, Y. Qi, and E. Wang: 'Selected-control synthesis of $\mathrm{PbO}_{2}$ and $\mathrm{Pb}_{3} \mathrm{O}_{4}$ single-crystalline nanorods', Journal of the American Chemical Society, 2003, 125(17), 49824983.

602. M. Abadir, A. Gadalla, and A. El, YM: 'Equilibrium relationships in the system lead-oxygen', Transactions and journal of the British Ceramic Society, 1976, 75, 68-70.

603. D. F. Smith: 'The condition of bismuth salts in aqueous solutions and the molal electrodepotential of bismuth', Journal of the American Chemical Society, 1923, 45(2), 360-370.

604. F. Abraham, D. Thomas, and G. Nowogrocki: 'Structure cristalline de $\mathrm{Bi}_{3} \mathrm{Ru}_{3} \mathrm{O}_{11}$ [Crystal structure of $\left.\mathrm{Bi}_{3} \mathrm{Ru}_{3} \mathrm{O}_{11}\right]^{\prime}$, Bulletin de la Société Française de Minéralogie et de Cristallographie, 1975, 98, 25-29.

605. G. R. Facer, M. M. Elcombe, and B. J. Kennedy: 'Bismuth ruthenium oxides. Neutron diffraction and photoelectron spectroscopic study of $\mathrm{Bi}_{2} \mathrm{Ru}_{2} \mathrm{O}_{7}$ and $\mathrm{Bi}_{3} \mathrm{Ru}_{3} \mathrm{O}_{11}{ }^{\prime}$, Australian Journal of Chemistry, 1993, 46(12), 1897-1907.

606. F. Abraham, J. Trehoux, and D. Thomas: 'La liaison métal - métal dans les clusters $\mathrm{M}_{12} \mathrm{O}_{36}$ : II - Préparation et étude structurale de la phase $\mathrm{La}_{3} \mathrm{Ru}_{3} \mathrm{O}_{11}$ [The metal-metal bond in $\mathrm{M}_{12} \mathrm{O}_{36}$ clusters: II - Preparation and structural study of the $\mathrm{La}_{3} \mathrm{Ru}_{3} \mathrm{O}_{11}$ phase]', Materials Research Bulletin, 1978, 13(8), 805-810.

607. B. Hallstedt, D. Risold, and L. J. Gauckler: 'Thermodynamic assessment of the bismuthcalcium-oxygen oxide system', J. Am. Ceram. Soc., 1997, 80(10), 2629-2636.

608. O. A. Gökçen, J. V. Styve, J. K. Meen, and D. Elthon: 'Phase equilibria of the $1 / 2 \mathrm{Bi}_{2} \mathrm{O}_{3}-\mathrm{CaO}$ system in oxygen at $1 \mathrm{~atm}$ pressure', J. Am. Ceram. Soc., 1999, 82(7), 1908-1914.

609. B. Hallstedt, D. Risold, and L. J. Gauckler: 'Thermodynamic assessment of the bismuthstrontium-oxygen oxide system', J. Am. Ceram. Soc., 1997, 80(5), 1085-1094.

610. K. T. Jacob and K. P. Jayadevan: 'System Bi-Sr-O: synergistic measurements of thermodynamic properties using oxide and fluoride solid electrolytes', Journal of Materials Research, 1998, 13(7), 1905-1918.

611. L. A. Klinkova, V. K. Fedotov, V. I. Nikolaichik, and N. V. Barkovskii: 'Phase relations in the Ba-Bi-O system between 20 and $80 \mathrm{~mol} \% \mathrm{BiO}_{1.5}$ at $p_{\mathrm{O} 2}=0.01,0.21$, and $1 \mathrm{~atm}$, Russian Journal of Inorganic Chemistry, 1999, 44(12), 1822-1829.

612. C. Chaillout, A. Santoro, J. P. Remeika, A. S. Cooper, G. P. Espinoza, and M. Marezio: 'Bismuth valence order-disorder study in $\mathrm{BaBiO}_{3}$ by powder neutron diffraction', Solid State Communications, 1988, 65(11), 1363-1369.

613. T. W. Kim, S. G. Hur, S. J. Hwang, H. Park, Y. Park, W. Choi, and J. H. Choy: 'Substitution effect of pentavalent bismuth ions on the electronic structure and physicochemical properties of perovskite-structured $\mathrm{Ba}\left(\mathrm{In}_{0.5} \mathrm{Ta}_{0.5-\mathrm{x}} \mathrm{Bi}_{\mathrm{x}}\right) \mathrm{O}_{3}$ semiconductors', MRS Bulletin, 2007, 42(11), 1914-1920. 
614. A. Lenz and H. Müller-Buschbaum: $\mathrm{Bi}^{5+}$ im monoklin verzerrten Perowskit $\mathrm{Sr}_{2} \mathrm{BiNdO}_{6}\left[\mathrm{Bi}^{5+}\right.$ in the monoclinically distorted perovskite $\left.\mathrm{Sr}_{2} \mathrm{BiNdO}_{6}\right]^{\prime}$, Journal of the Less-Common Metals, 1990, 161(1), 141-146.

615. A. Lenz and H. Müller-Buschbaum: 'Eine Anmerkung über geordnete Perowskite mit $\mathrm{Bi}^{5+}$ : $\mathrm{Ba}_{2} \mathrm{BiMO}_{6}\left(\mathrm{M} \equiv \mathrm{Y}\right.$, Dy) [A note on ordered perovskites with $\mathrm{Bi}^{5+}: \mathrm{Ba}_{2} \mathrm{BiMO}_{6}(\mathrm{M} \equiv \mathrm{Y}, \mathrm{Dy})^{\prime}$, Journal of the Less-Common Metals, 1990, 161(1), L15-L17.

616. C. Levy-Clément, I. Morgenstern-Badarau, and A. Michel: 'Mise en évidence de deux nouveaux oxydes doubles de type ilmenite: Les plombates de cadmium $\mathrm{CdPbO}_{3}$ et de calcium $\mathrm{CaPbO}_{3}$ [Discovery of two new double ilmenite-type oxides: The plumbates of cadmium $\mathrm{CdPbO}_{3}$ and calcium $\left.\mathrm{CaPbO}_{3}\right]^{\prime}$, Materials Research Bulletin, 1972, 7(1), 35-43.

617. W. Wong-Ng, F. Jiang, and L. P. Cook: 'Phase relationships of the Pb-Sr-Ca-O system in air', Physica C, 1996, 272(1-2), 87-93.

618. K. L. Keester and W. B. White: 'Crystal chemistry and properties of phases in the system SrOPbO-O', Journal of Solid State Chemistry, 1970, 2(1), 68-73.

619. K. T. Jacob and K. P. Jayadevan: 'Phase relations, chemical potentials and thermodynamic properties of interoxide compounds in the system $\mathrm{Ba}-\mathrm{Pb}-\mathrm{O}$ ', Materials Science and Engineering, 1998, B52(2-3), 134-144.

620. W. T. Fu, D. Visser, and D. J. W. IJdo: 'High-resolution neutron powder diffraction study on the structure of $\mathrm{BaPbO}_{3}$ ', Solid State Communications, 2005, 134(10), 647-652

621. H. U. Anderson: 'Review of p-type doped perovskite materials for SOFC and other applications', Solid State Ionics, 1992, 52(1-3), 33-41.

622. Y. Idemoto, Y. Yasuda, and K. Fueki: 'Thermodynamic stability of $\left(\mathrm{La}_{1-\mathrm{x}} \mathrm{M}_{\mathrm{x}}\right)_{2} \mathrm{CuO}_{\mathrm{y}}(\mathrm{M}=\mathrm{Ba}$, $\mathrm{Sr}$ and Ca) solid solution and the 1/8 anomaly', Physica C, 1995, 243(1-2), 35-42.

623. M. Karppinen, A. Fukuoka, L. Niinistö, and H. Yamauchill: 'Determination of oxygen content and metal valences in oxide superconductors by chemical methods', Superconductor Science and Technology, 1996, 9(3), 121-135.

624. H. Yokokawa, T. Horita, N. Sakai, K. Yamaji, M. E. Brito, Y. Xiong, and H. Kishimoto: 'Thermodynamic considerations on Cr poisoning in SOFC cathodes', Solid State Ionics, 2006, 177(35-36), 3193-3198.

625. D. C. Kim, A. N. Baranov, J. S. Kim, H. R. Kang, B. J. Kim, Y. C. Kim, J. S. Pshirkov, E. V. Antipov, and Y. W. Park: 'High pressure synthesis and superconductivity of $\mathrm{Ba}_{1-\mathrm{x}} \mathrm{K}_{\mathrm{x}} \mathrm{BiO}_{3}$ $(0.35<\mathrm{x}<1)$ ', Physica C, 2003, 383(4), 343-353.

626. S. Kodialam, V. C. Korthius, R. D. Hoffmann, and A. W. Sleight: 'Electrodeposition of potassium bismuthate: $\mathrm{KBiO}_{3}{ }^{\prime}$, MRS Bulletin, 1992, 27(12), 1379-1384.

627. B. Schwedes and R. Hoppe: 'Über Oxobismutate - Zur Kenntnis von $\mathrm{Na}_{3} \mathrm{BiO}_{4}$ und $\mathrm{Na}_{3} \mathrm{SbO}_{4}$ [On oxobismuthates - The compounds $\mathrm{Na}_{3} \mathrm{BiO}_{4}$ and $\mathrm{Na}_{3} \mathrm{SbO}_{4}$ ]', Zeitschrift für anorganische und allgemeine Chemie, 1972, 393(2), 136-148.

628. L. A. Klinkova, V. I. Nikolaichik, N. V. Barkovskii, and V. K. Fedotov: 'Thermal stability of $\mathrm{Bi}_{2} \mathrm{O}_{3}{ }^{\prime}$, Russian Journal of Inorganic Chemistry, 2007, 52(12), 1822-1829.

629. S. F. Radaev, V. I. Simonov, and Y. F. Kargin: 'Structural features of $\gamma$-phase $\mathrm{Bi}_{2} \mathrm{O}_{3}$ and its place in the sillenite family', Acta Crystallographica, 1992, B48(5), 604-609.

630. M. Burianek, P. Held, and M. Mühlberg: 'Improved single crystal growth of the boron sillenite " $\mathrm{Bi}_{24} \mathrm{~B}_{2} \mathrm{O}_{39}$ " and investigation of the crystal structure', Crystal Research and Technology, 2002, 37(8), 785-796.

631. M. Valant and D. Suvorov: 'A stoichiometric model for sillenites', Chemistry of Materials, 2002, 14(8), 3471-3476.

632. H. Kruidhof, H. J. M. Bouwmeester, K. J. de Vries, P. J. Gellings, and A. J. Burggraaf: 'Thermochemical stability and nonstoichiometry of erbia-stabilized bismuth oxide', Solid State Ionics, 1992, 50(1-2), 181-186. 
633. R. S. Bubnova, S. V. Krivovichev, S. K. Filatov, A. V. Egorysheva, and Y. F. Kargin: 'Preparation, crystal structure and thermal expansion of a new bismuth barium borate, $\mathrm{BaBi}_{2} \mathrm{~B}_{4} \mathrm{O}_{10}{ }^{\prime}$, Journal of Solid State Chemistry, 2007, 180(2), 596-603.

634. G. von der Gönna and C. Rüssel: 'Thermodynamics of various polyvalent elements in a $15 \mathrm{Na}_{2} \mathrm{O} \cdot 85 \mathrm{SiO}_{2}$ glass melt', Journal of Non-Crystalline Solids, 2000, 262(1-3), 236-243.

635. S. P. S. Badwal and F. T. Ciacchi: 'Ceramic membrane technologies for oxygen separation', Advanced Materials, 2001, 13(12-13), 993-996.

636. B. Kusz, K. Trzebiatowski, M. Gazda, and L. Murawski: 'Structural studies and melting of bismuth nanocrystals in reduced bismuth germanate and bismuth silicate glasses', Journal of Non-Crystalline Solids, 2002, 328(1-3), 137-145.

637. A. N. Romanov, Z. T. Fattakhova, D. M. Zhigunov, V. N. Korchak, and V. B. Sulimov: 'On the origin of near-IR luminescence in Bi-doped materials (I). Generation of low-valence bismuth species by $\mathrm{Bi}^{3+}$ and $\mathrm{Bi}^{0}$ synproportionation', Optical Materials, 2011, 33(4), 631-634.

638. S. Fujiwara, T. Suzuki, N. Sugimoto, H. Kanbara, and K. Hirao: 'THz optical switching in glasses containing bismuth oxide', Journal of Non-Crystalline Solids, 1999, 259(1-3), 116120.

639. N. J. Bjerrum, C. R. Boston, and G. P. Smith: 'Lower oxidation states of bismuth. $\mathrm{Bi}^{+}$and $\left[\mathrm{Bi}_{5}\right]^{3+}$ in molten salt solutions', Inorganic Chemistry, 1967, 6(6), 1162-1172.

640. R. D. Shannon: 'Revised effective ionic radii and systematic studies of interatomic distances in halides and chalcogenides', Acta Crystallographica, 1976, A32, 751-767.

641. D. J. Payne, R. G. Egdell, A. Walsh, G. W. Watson, J. Guo, P. A. Glans, T. Learmonth, and K. E. Smith: 'Electronic origins of structural distortions in post-transition metal oxides: experimental and theoretical evidence for a revision of the lone pair model', Physical Review Letters, 2006, 96(15), 157403.

642. A. Walsh, G. W. Watson, D. J. Payne, R. G. Edgell, J. Guo, P. A. Glans, T. Learmonth, and K. E. Smith: 'Electronic structure of the $\alpha$ and $\delta$ phases of $\mathrm{Bi}_{2} \mathrm{O}_{3}$ : A combined ab initio and x-ray spectroscopy study', Physical Review B, 2006, 73(23), 235104.

643. C. E. Mohn, S. Stølen, S. T. Norberg, and S. Hull: 'Oxide-ion disorder within the high temperature $\delta$ Phase of $\mathrm{Bi}_{2} \mathrm{O}_{3}{ }^{\prime}$, Physical Review Letters, 2009, 102(15), 155502.

644. N. E. Brese and M. O'Keefe: 'Bond-valence parameters for solids', Acta Crystallographica, 1991, B47(2), 192-197.

645. H. A. Harwig: 'On the structure of bismuth sesquioxide: The $\alpha, \beta, \gamma$, and $\delta$-phase', Zeitschrift für Anorganische und Allgemeine Chemie, 1978, 28(1), 8737-8745.

646. H. A. Harwig and A. G. Gerards: 'The polymorphism of bismuth sesquioxide', Thermochimica Acta, 1979, 28(1), 121-131.

647. F. D. Hardcastle and I. E. Wachs: 'The molecular structure of bismuth oxide by Raman spectroscopy', Journal of Solid State Chemistry, 1992, 97(2), 319-331.

648. S. Hull, S. T. Norberg, M. G. Tucker, S. G. Eriksson, C. E. Mohn, and S. Stølen: 'Neutron total scattering study of the $\delta$ and $\beta$ phases of $\mathrm{Bi}_{2} \mathrm{O}_{3}$, Dalton Transactions, 2009, 38(40), 8737-8745.

649. P. Conflant, J. C. Boivin, and D. Thomas: 'Étude structurale du conducteur anionique $\mathrm{Bi}_{0.765} \mathrm{Sr}_{0.235} \mathrm{O}_{1.383}$ [Structural study of the anionic conductor $\mathrm{Bi}_{0.765} \mathrm{Sr}_{0.235} \mathrm{O}_{1.383}$ ]', Journal of Solid State Chemistry, 1980, 35(2), 192-199.

650. S. K. Blower and C. Greaves: 'The structure of $\beta-\mathrm{Bi}_{2} \mathrm{O}_{3}$ from powder neutron diffraction data', Acta Crystallographica, 1988, C44(4), 587-589.

651. L. G. Sillén: 'X-ray studies on bismuth trioxide', Arkiv för Kemi, Mineralogi och Geologi, 1937, 12A(18), 1-13.

652. B. Aurivillius and L. G. Sillén: 'Polymorphy of bismuth trioxide', Nature, 1945, 155(3932), 305-306. 
653. P. D. Battle, C. R. A. Catlow, J. Drennan, and A. D. Murray: 'The structural properties of the oxygen conducting $\delta$ phase of $\mathrm{Bi}_{2} \mathrm{O}_{3}{ }^{\prime}$, Journal of Physics C: Solid State Physics, 1983, 16(17), L561-L566.

654. C. D. Ling, R. L. Withers, S. Schmid, and J. G. Thompson: 'A review of bismuth-rich binary oxides in the systems $\mathrm{Bi}_{2} \mathrm{O}_{3}-\mathrm{Nb}_{2} \mathrm{O}_{5}, \mathrm{Bi}_{2} \mathrm{O}_{3}-\mathrm{Ta}_{2} \mathrm{O}_{5}, \mathrm{Bi}_{2} \mathrm{O}_{3}-\mathrm{MoO}_{3}$, and $\mathrm{Bi}_{2} \mathrm{O}_{3}-\mathrm{WO}_{3}{ }^{\prime}$, Journal of Solid State Chemistry, 1998, 137(1), 42-61.

655. D. S. Aidhy, J. C. Nino, S. B. Sinnott, E. D. Wachsman, and S. R. Phillpot: 'Vacancy-ordered structure of cubic bismuth oxide from simulation and crystallographic analysis', J. Am. Ceram. Soc., 2008, 91(7), 2349-2356.

656. S. T. Norberg, S. G. Eriksson, and S. Hull: 'Comparison of short-range ion-ion correlations in the $\alpha, \beta$ and $\delta$ phases of $\mathrm{Bi}_{2} \mathrm{O}_{3}{ }^{\prime}$, Solid State Ionics, 2011, 192(1), 409-412.

657. S. C. Abrahams, P. B. Jamieson, and J. L. Bernstein: 'Crystal structure of piezoelectric bismuth germanium oxide $\mathrm{Bi}_{12} \mathrm{GeO}_{20}$ ', Journal of Chemical Physics, 1967, 47(10), 4034-4043.

658. S. C. Abrahams, J. L. Bernstein, and C. Svensson: 'Crystal structure and absolute piezoelectric $\mathrm{d}_{14}$ coefficient in laevorotatory $\mathrm{Bi}_{12} \mathrm{SiO}_{20}{ }^{\prime}$, Journal of Chemical Physics, 1979, 71(2), 788-792.

659. S. F. Radaev and V. I. Simonov: 'Structures of sillenites and atomic mechanisms of their isomorphic substitutions', Soviet Physics - Crystallography, 1992, 37(4), 484-499.

660. A. Hyman and B. Perloff: 'The crystal structure of bismuth (2:1) borate, $2 \mathrm{Bi}_{2} \mathrm{O}_{3} \cdot \mathrm{B}_{2} \mathrm{O}_{3}{ }^{\prime}$, Acta Crystallographica B, 1972, 28(7), 2007-2011.

661. J. Barbier and L. M. Cranswick: 'The non-centrosymmetric borate oxides, $\mathrm{MBi}_{2} \mathrm{~B}_{2} \mathrm{O}_{7}(\mathrm{M}=\mathrm{Ca}$, Sr)', Journal of Solid State Chemistry, 2006, 179(12), 3958-3964.

662. E. H. Arbib, B. Elouadid, J. P. Chaminade, and J. Darriet: 'The crystal structure of the phosphate eulytite $\mathrm{Ba}_{3} \mathrm{Bi}\left(\mathrm{PO}_{4}\right)_{3}{ }^{\prime}$, Materials Research Bulletin, 2000, 35(5), 761-773.

663. M. Avdeev, M. K. Haas, J. D. Jorgensen, and R. J. Cava: 'Static disorder from lone-pair electrons in $\mathrm{Bi}_{2-\mathrm{x}} \mathrm{M}_{\mathrm{x}} \mathrm{Ru}_{2} \mathrm{O}_{7-\mathrm{y}}(\mathrm{M}=\mathrm{Cu}, \mathrm{Co} ; \mathrm{x}=0,0.4)$ pyrochlores', Journal of Solid State Chemistry, 2002, 169(1), 24-34.

664. S. Filatov, Y. Shepelev, R. Bubnova, N. Sennova, A. V. Egorysheva, and Y. F. Kargin: 'The study of $\mathrm{Bi}_{3} \mathrm{~B}_{5} \mathrm{O}_{12}$ : synthesis, crystal structure and thermal expansion of oxoborate $\mathrm{Bi}_{3} \mathrm{~B}_{5} \mathrm{O}_{12}{ }^{\prime}$, Journal of Solid State Chemistry, 2004, 177(2), 515.522.

665. G. Malmros: 'The crystal structure of $\alpha-\mathrm{Bi}_{2} \mathrm{O}_{3}{ }^{\prime}$, Acta Chemica Scandinavica, 1970, 24(2), 235104.

666. B. J. Kennedy and T. Vogt: 'Structural and bonding trends in ruthenium pyrochlores', Journal of Solid State Chemistry, 1996, 126(2), 261-270.

667. H. J. Koo, M. H. Whangbo, and B. J. Kennedy: 'Similarities and differences in the structural and electronic properties of ruthenium and iridium pyrochlores $\mathrm{A}_{2} \mathrm{M}_{2} \mathrm{O}_{7-\mathrm{y}}(\mathrm{M}=\mathrm{Ru}, \mathrm{Ir})^{\prime}$, Journal of Solid State Chemistry, 1998, 136(2), 269-273.

668. P. A. Cox, R. G. Egdell, J. B. Goodenough, A. Hamnett, and C. C. Naish: 'The metal-tosemiconductor transition in ternary ruthenium (IV) oxides: a study by electron spectroscopy', Journal of Physics C: Solid State Physics, 1983, 16(32), 6221-6239.

669. W. L. Lee, M. K. Haas, G. Lawes, A. P. Ramirez, R. J. Cava, and N. P. Ong: 'Field tuning of the electron and hole populations in the ruthenate $\mathrm{Bi}_{3} \mathrm{Ru}_{3} \mathrm{O}_{11}$ ', EPL - Europhysics Letters, 2003, 63(6), 860-866.

670. M. G. Brik and A. M. Srivastava: 'Pyrochlore structural chemistry: predicting the lattice constant by the ionic radii and electronegativities of the constituting ions', J. Am.Ceram. Soc., 2012, 95(4), 1454-1460.

671. S. Georges, F. Goutenoire, and P. Lacorre: 'Crystal structure of lanthanum bismuth silicate $\mathrm{Bi}_{2-\mathrm{x}} \mathrm{La}_{\mathrm{x}} \mathrm{SiO}_{5}(\mathrm{x} \sim 0.1)^{\prime}$, Journal of Solid State Chemistry, 2006, 179(12), 4020-4028. 
672. B. Aurivillius, C.-I. Lundblom, and P. Stenson: 'The crystal structure of $\mathrm{Bi}_{2} \mathrm{GeO}_{5}$ ', Acta Chemica Scandinavica, 1964, 18, 1555-1557.

673. P. Fischer and F. Waldner: 'Comparison of neutron diffraction and EPR results on the cubic crystal structures of piezoelectric $\mathrm{Bi}_{4} \mathrm{Y}_{3} \mathrm{O}_{12}(\mathrm{Y}=\mathrm{Ge}, \mathrm{Si})$ ', Solid State Communications, 1982, 44(5), 657-661.

674. B. C. Grabmaier, S. Haussühl, and P. Klüfers: 'Crystal growth, structure, and physical properties of $\mathrm{Bi}_{2} \mathrm{Ge}_{3} \mathrm{O}_{9}$ ', Zeitschrift für Kristallographie, 1979, 149(3-4), 261-267.

675. X. Chen, J. Zuo, X. Chang, Y. Zhao, H. Zang, and W. Xiao: 'Synthesis and crystal structure of a novel ternary oxoborate, $\mathrm{PbBiBO}_{4}$, Journal of Solid State Chemistry, 2006, 179(10), 31913195 .

676. J. Barbier, N. Penin, and L. M. Cranswick: 'Melilite-type borates $\mathrm{Bi}_{2} \mathrm{ZnB}_{2} \mathrm{O}_{7}$ and $\mathrm{CaBiGaB}_{2} \mathrm{O}_{7}{ }^{\prime}$, Chemistry of Materials, 2006, 17(12), 3130-3136.

677. R. Fröhlich, L. Bohatý, and J. L. Liebertz: 'Die Kristallstruktur von Wismutborat, $\mathrm{BiB}_{3} \mathrm{O}_{6}[$ The crystal structure of bismuth borate, $\left.\mathrm{BiB}_{3} \mathrm{O}_{6}\right]^{\prime}$, Acta Crystallographica, 1984, C40(3), 343-344.

678. M. Bagieu-Beucher and M.-T. Averbuch-Pouchot: 'Crystal data and crystal structure of bismuth tetraphosphate: $\mathrm{Bi}_{2} \mathrm{P}_{4} \mathrm{O}_{13}$ ', Zeitschrift für Kristallographie, 1987, 180(1-4), 165-170.

679. J. Leciejewicz: 'On the crystal structure of tetragonal (red) $\mathrm{PbO}^{\prime}$, Acta Crystallographica, 1961, 14(12), 1304.

680. R. J. Hill: 'Refinement of the structure of orthorhombie PbO (massicot) by Rietveld analysis of neutron powder diffraction data', Acta Crystallographica, 1985, C41(9), 1281-1284.

681. K. Kato: 'Die OD-Struktur von Bleisilicat $\mathrm{Pb}_{2} \mathrm{SiO}_{4}$ und Bleisilicat-germanat-Mischkristall $\mathrm{Pb}_{2}(\mathrm{Si}, \mathrm{Ge}) \mathrm{O}_{4}$ [The OD structure of lead silicate $\mathrm{Pb}_{2} \mathrm{SiO}_{4}$ and lead silicate germanate solid solution $\left.\mathrm{Pb}_{2}(\mathrm{Si}, \mathrm{Ge}) \mathrm{O}_{4}\right]^{\prime}$, Acta Crystallographica, 1980, B36(11), 2539-2545.

682. M. L. Boucher and D. R. Peacor: 'The crystal structure of alamosite, $\mathrm{PbSiO}_{3}$ ', Zeitschrift für Kristallographie, 1968, 126(1-3), 98-111.

683. J. Krogh-Moe and P. S. Wold-Hansen: 'The crystal structure of hexalead pentaborate, $6 \mathrm{PbO} \cdot 5 \mathrm{~B}_{2} \mathrm{O}_{3}{ }^{\prime}$, Acta Crystallographica, 1973, B36(11), 2242-2246.

684. U. Keppler: 'Die Struktur der Tieftemperaturform des Bleiphosphates $\mathrm{Pb}_{3}\left(\mathrm{PO}_{4}\right)_{2}$ [The structure of the low-temperture form of lead phosphate $\left.\mathrm{Pb}_{3}\left(\mathrm{PO}_{4}\right)_{2}\right]^{\prime}$, Zeitschrift für Kristallographie, $1970,132(1-6), 228-235$.

685. J. Pannetier and G. Denes: 'Tin(II) oxide: structure refinement and thermal expansion', Acta Crystallographica, 1980, B36(11), 2763-2765.

686. M. Mathew, L. W. Schroeder, and T. H. Jordan: 'The crystal structure of anhydrous stannous phosphate, $\mathrm{Sn}_{3}\left(\mathrm{PO}_{4}\right)_{2}{ }^{\prime}$, Acta Crystallographica, 1977, B33(6), 1812-1816.

687. V. V. Chernaya, A. S. Mitiaev, P. S. Chizhov, E. V. Dikarev, R. V. Shpanchenko, E. V. Antipov, M. V. Korolenko, and P. B. Fabritchnyi: 'Synthesis and investigation of tin(II) pyrophosphate $\mathrm{Sn}_{2} \mathrm{P}_{2} \mathrm{O}_{7}$ ', Chemistry of Materials, 2005, 17(2), 284-290.

688. S. Block and A. Perloff: 'The crystal structure of barium tetraborate, $\mathrm{BaO} \cdot 2 \mathrm{~B}_{2} \mathrm{O}_{3}{ }^{\prime}$, Acta Crystallographica, 1965, 19, 297-300.

689. A. Nakatsuka, O. Ohtaka, H. Arima, N. Nakayama, and T. Mizota: 'Aragonite-type lanthanum orthoborate, $\mathrm{LaBO}_{3}{ }^{\prime}$, Acta Crystallographica, 2006, E62(4), i103-i105.

690. P. Roux: 'Cours de thermique', course, France, http://philippe.roux.7.perso.neuf.fr/, 2007. 